Universidade de São Paulo

Faculdade de Filosofia, Letras e Ciências Humanas

Departamento de Ciência Política

\title{
A disputa entre PSDB e PT nas eleições presidenciais $1994-2006$
}

José Paulo Martins Junior

São Paulo

2007 
Universidade de São Paulo

Faculdade de Filosofia, Letras e Ciências Humanas

Departamento de Ciência Política

\section{A disputa entre PSDB e PT nas eleições presidenciais $1994-2006$}

José Paulo Martins Junior

Tese apresentada ao Programa de Pós-Graduação do Departamento de Ciência Política da Faculdade de Filosofia, Letras e Ciências Humanas da Universidade de São Paulo, sob orientação da Profa. Dr a. Maria D'Alva Gil Kinzo, para a obtenção do título de Doutor.

São Paulo 


\section{Folha de Aprovação}

José Paulo Martins Junior

A disputa entre PSDB e PT nas eleições presidenciais 1994-2006

Tese apresentada ao Programa de Pós-Graduação do Departamento de Ciência Política da Faculdade de Filosofia, Letras e Ciências Humanas da Universidade de São Paulo, sob orientação da Profa. Dr a. Maria D'Alva Gil Kinzo, para a obtenção do título de Doutor.

Aprovado em:

\section{Banca Examinadora}

Profa. Dr a. Maria D'Alva Gil Kinzo (orientadora)

Universidade de São Paulo

Assinatura:

Prof. Dr. Fernando de Magalhães Papaterra Limongi

Universidade de São Paulo

Assinatura:

Prof. Dr. André Vitor Singer

Universidade de São Paulo

Assinatura:

Prof ${ }^{a}$. Dr ${ }^{\text {a }}$. Rachel Meneghello

Universidade Estadual de Campinas

Assinatura:

Prof. Dr. Yan de Souza Carreirão

Universidade Federal de Santa Catarina

Assinatura: 
Para Flávia e Joaquim 


\section{Agradecimentos}

Desde 1990 sou estudante de uma universidade estadual paulista. Até 1992 estive na Universidade de Estadual de Campinas e a partir do ano seguinte até hoje na Universidade de São Paulo. Ser aluno dessas universidades contribuiu muito para a minha formação pessoal e acadêmica. Em toda essa trajetória, muitas pessoas e instituições foram importantes, mas algumas foram decisivas e devem ser nomeadas.

Maria D'Alva Gil Kinzo foi quem melhor acompanhou minhas atividades acadêmicas. Desde a iniciação científica até o último momento para entregar a tese sempre encontrei nela total disposição em ouvir o que eu falava, ler o que eu escrevia, acreditar no que eu prometia. Sua orientação sempre foi presente, segura, séria e exigente e eu agradeço muito por isso.

Outros professores do Departamento de Ciência Política da Universidade de São Paulo influenciaram a realização dessa pesquisa em diversas situações, na sala de aula, no laboratório, em comentários aos trabalhos escritos, ao projeto de pesquisa e no exame de qualificação. Agradeço muito a Fernando Limongi, Leandro Piquet Carneiro, André Singer, Gildo Marçal Brandão, Gabriel Cohn, Cláudio Vouga, Maria Hermínia Tavares de Almeida, e Elisabeth Balbachevsky.

Também tive aulas e trabalhei com Örjan Olsen, que foi professor convidado no DCP-USP. Com ele aprendi muito sobre análise de dados quantitativos e estratégias de campanhas eleitorais, além disso sou grato pelos dados das pesquisas eleitorais de 2002 e 2006 que ele gentilmente me cedeu para a realização deste trabalho.

Agradeço aos professores do curso de metodologia quantitativa da Universidade Federal de Minas Gerais, especialmente Nelson do Valle Silva e Jorge Alexandre Neves, aprendi muito com eles.

Voltando ao DCP, sou grato ao trabalho sempre atencioso dos funcionários, em especial Márcia, Raí, Ana Maria e Vivian. Sem vocês tudo seria mais difícil.

Em tantos anos de DCP-FFLCH, são muitos os amigos, quero destacar Humberto Dantas e Maurício Moya, que ingressaram comigo em 1993 nas Ciências Sociais e são grandes companheiros para todas as horas. 
Na pós-graduação tive queridos amigos do grupo de pesquisa sobre Partidos e Representação Política, como Maria do Socorro Souza Braga, Ivan Borin, Hilton Fernandes, Jairo Pimentel, Tiago Borges, Ludmila Chaves, Ana Carolina Hirano, Sérgio Praça, Simone Bohn e Raiane Severino.

Simone Diniz, Sandra Gomes, Vanessa Elias de Oliveira, Ernani Carvalho, Renata Bichir, Rosi Rosendo, Rogério Schelgel, Thaís Pavez, Emmanuel de Oliveira, Flávia Rossi, Tatiana Ribeiral, Gabriela Piquet, Maria Fernanda Lombardi, Gonzalo Rojas, José Henrique Artigas de Godoy, Pedro Campos, André Knees são alguns dos amigos que acompanharam meu trabalho na universidade. Muito obrigado pela amizade e pelo carinho que sempre me dedicaram.

Deve agradecer também os amigos da Toledo \& Associados, especialmente Francisco José de Toledo e Maria Aparecida Amorim de Toledo, que acompanharam e incentivaram toda minha trajetória acadêmica.

Os diretores, professores, funcionários e alunos da Fundação Escola de Sociologia e Política de São Paulo, instituição em que leciono e pesquiso desde 2005, compreenderam e estimularam meu trabalho de redação final desta tese.

Durante a realização deste trabalho recebi apoio financeiro do Conselho Nacional de Pesquisa - CNPq, da Coordenadoria de Aperfeiçoamento de Pessoal e Ensino Superior - CAPES e da Fundação Ford. A primeira financiou todo o projeto e as duas últimas o curso de metodologia quantitativa da UFMG.

Tenho que agradecer também à minha avó, meus pais, minha irmã, meus sobrinhos, sogra, sogro e cunhados pelo apoio sempre incondicional. Finalmente, devo agradecer meus amores à Flávia e ao Joaquim. 


\section{Epígrafe}

Ela entrou com embaraço, tentou sorrir, e perguntou tristemente - se eu a reconhecia?

O aspecto carnavalesco Ihe vinha menos do frangalho de fantasia do que do seu ar de extrema penúria. Fez por permanecer alegre. Mas o sorriso se Ihe transmudou em ricto amargo. $E$ os olhos ficaram baços, como duas poças de água suja... Então, para cortar o soluço que adivinhei subindo de sua garganta, puxei para o pé de mim e, com doçura:

- Tu és a minha esperança de felicidade e cada dia que passa eu te quero mais, com perdida volúpia e angústia...

Manuel Bandeira 


\title{
Resumo
}

Esta tese de doutoramento trata da disputa entre o PSDB e o PT nas eleições presidenciais ocorridas no Brasil entre 1994 e 2006. O objetivo principal é identificar quais são as variáveis que estão associadas ao voto nos dois partidos que nos permitem prever com alguma precisão as chances de voto em cada um deles. A análise será procedida com auxílio de bancos de dados representativos dos eleitores brasileiros. São observadas diversas variáveis, classificadas em dois grupos: no primeiro estão as variáveis relacionadas a aspectos de longo prazo que incidem sobre o comportamento eleitoral, as características demográficas, sócio-econômicas e político-ideológicas dos eleitores, no segundo estão as variáveis ligadas diretamente ao processo eleitoral, as avaliações dos governos e dos candidatos.

A hipótese mais importante a ser testada é que as variáveis de curto prazo têm impacto muito maior sobre as chances de voto nos partidos do que as variáveis de longo prazo. Isso indica que o contexto eleitoral afeta mais o resultado das eleições presidenciais do que qualquer aspecto estrutural, seja social, econômico ou político. Os resultados obtidos com a utilização de regressões logísticas corroboram a hipótese e apontam para diferenças importantes entre o voto no PSDB e no PT.

Palavras-chave: eleições presidenciais; partidos políticos; ideologia; avaliação; qualidades; problemas.

\begin{abstract}
This Ph.D. thesis is about the dispute between the PSDB and PT for presidential elections ran in Brazil between 1994 e 2006. Its main objective is to identify the variables linked to votes given for both parties which would lead us to predict under a certain precision degree the chances each one has against other. The analysis is based on relevant databases from brazilian electoral activities. Several variables were observed and separated in two different groups: the first contains the ones related to long term aspects linked to the voters behavior as well as demographics, socio-economic, and political-ideological variables, while the second one contains the variables directly linked to the electoral process, to candidates evaluations and the country issues.

The most important hypothesis to be tested is the one of short term variables making a bigger impact over each party vote chance when compared to the long term ones. Considering the hypothesis valuable, this presents the scenary of the electoral context with a bigger effect over presidential election than any other voter structural aspect either social, economic or political. The given result corroborates with the hypothesis and came from logistics regressions, pointing out relevant differences between votes given in favour of PSDB and PT.
\end{abstract}

Keywords: presidential elections; political parties; ideology; evaluation; qualities; problems. 


\section{LISTA DE QUADROS E TABELAS}

\section{Quadros}

Quadro 1: Modelo de regressão logística para a ocorrência de voto no PSDB - Sexo

Quadro 2: Modelo de regressão logística para a ocorrência de voto no PT - Sexo

Quadro 3: Modelo de regressão logística para a ocorrência de voto no PSDB - Idade

Quadro 4: Modelo de regressão logística para a ocorrência de voto no PT - Idade

Quadro 5: Modelo de regressão logística para a ocorrência de voto no PSDB -

Escolaridade

Quadro 6: Modelo de regressão logística para a ocorrência de voto no PT -

Escolaridade

Quadro 7: Modelo de regressão logística para a ocorrência de voto no PSDB - Renda familiar

Quadro 8: Modelo de regressão logística para a ocorrência de voto no PT - Renda

familiar

Quadro 9: Modelo de regressão logística para a ocorrência de voto no PSDB - PEA

Quadro 10: Modelo de regressão logística para a ocorrência de voto no PT - PEA

Quadro 11: Modelo de regressão logística para a ocorrência de voto no PSDB - Etnia

Quadro 12: Modelo de regressão logística para a ocorrência de voto no PT - Etnia

Quadro 13: Modelo de regressão logística para a ocorrência de voto no PSDB -

Religião

Quadro 14: Modelo de regressão logística para a ocorrência de voto no PT - Religião

Quadro 15: Modelo de regressão logística para a ocorrência de voto no PSDB -

Região

Quadro 16: Modelo de regressão logística para a ocorrência de voto no PT - Região

Quadro 17: Modelo de regressão logística para a ocorrência de voto no PSDB - Tipo de cidade

Quadro 18: Modelo de regressão logística para a ocorrência de voto no PT - Tipo de cidade

Quadro 19: Modelo de regressão logística para a ocorrência de voto no PSDB -

Conjunto das Variáveis socioeconômicas

Quadro 20: Modelo de regressão logística para a ocorrência de voto no PT - Conjunto das Variáveis socioeconômicas

Quadro 21: Modelo de regressão logística para a ocorrência de voto no PSDB -

Preferência pelo PSDB

Quadro 22: Modelo de regressão logística para a ocorrência de voto no PSDB -

Preferência pelo PT, PSDB, PMDB e PFL

Quadro 23: Modelo de regressão logística para a ocorrência de voto no PT -

Preferência pelo PT

Quadro 24: Modelo de regressão logística para a ocorrência de voto no PT -

Preferência pelo PT, PSDB, PMDB e PFL

Quadro 25: Modelo de regressão logística para a ocorrência de voto no PSDB -

Avaliação do PT, PSDB, PMDB e PFL

Quadro 26: Modelo de regressão logística para a ocorrência de voto no PT - Avaliação

do PT, PSDB, PMDB e PFL

Quadro 27: Modelo de regressão logística para a ocorrência de voto no PSDB -

Variáveis ideológicas

Quadro 28: Modelo de regressão logística para a ocorrência de voto no PT - Variáveis ideológicas

Quadro 29: Modelo de regressão logística para a ocorrência de voto no PSDB -

Conjunto das variáveis de longo prazo

Quadro 30: Modelo de regressão logística para a ocorrência de voto no PT - Conjunto das variáveis de longo prazo

Quadro 31: Modelo de regressão logística para a ocorrência de voto no PSDB -

Avaliação de governo

Quadro 32: Modelo de regressão logística para a ocorrência de voto no PT - Avaliação de governo 
Quadro 33: Modelo de regressão logística para a ocorrência de voto no PSDB e no PT em 1998 - Qualidades e características do candidato

Quadro 34: Modelo de regressão logística para a ocorrência de voto no PSDB e no PT em 2002 - Qualidades e características do candidato

Quadro 35: Modelo de regressão logística para a ocorrência de voto no PSDB e no PT em 2006 - Qualidades e características do candidato

Quadro 36: Modelo de regressão logística para a ocorrência de voto no PSDB -

Capacidade do candidato

Quadro 37: Modelo de regressão logística para a ocorrência de voto no PT -

Capacidade do candidato

Quadro 38: Comparativo dos $\mathrm{R}^{2}$ obtidos nos modelos

Quadro 39: Modelo geral de regressão logística para a ocorrência de voto no PSDB

Quadro 40: Modelo geral de regressão logística para a ocorrência de voto no PT

\section{Tabelas}

Tabela 1: Características socioeconômicas dos eleitores

Tabela 2: Partidos efetivos em eleições majoritárias

Tabela 3: Preferência partidária nos anos de realização de eleição presidencial 84

Tabela 4: Avaliação dos partidos $\quad 85$

Tabela 5: Opiniões sobre privatizações e venda de bancos a estrangeiros em 1998 (em \%) $\quad 98$

Tabela 6: Autoposicionamento ideológico em $2002 \quad 98$

Tabela 7: Opinião sobre o combate ao crime e a violência em $2006 \quad 99$

Tabela 8: Avaliação de desempenho do governo nas campanhas de 1994 a $2006 \quad 137$

Tabela 9: Principais qualidades que um candidato deve ter - campanha de $1998 \quad 142$

Tabela 10: Opinião dos eleitores sobre quem tem as principais qualidades para ser presidente em 1998 (\%)

Tabela 11: Principais qualidades que um candidato deve ter - campanha de $2002 \quad 147$

Tabela 12: Opinião dos eleitores sobre quem tem as principais qualidades para ser presidente em 2002

Tabela 13: Principais qualidades que um candidato deve ter - campanha de $2006 \quad 152$

Tabela 14: Opinião dos eleitores sobre quem tem as principais qualidades para ser presidente em 2006 (em \%) 
INTRODUÇÃO 1

PREÂMBULO METODOLÓGICO 8

CAPÍTULO 1. MODELO SOCIOLÓGICO DE DECISÃO DE VOTO 13

1.1. Introdução 13

1.2. A abordagem sociológica do comportamento eleitoral na literatura internacional $\quad 14$

1.3. A abordagem socioeconômica da decisão do voto no Brasil 21

1.3.1. Geografia do voto 22

1.3.2. Análises eleitorais com dados de survey com amostras
subnacionais

1.3.3. Análises eleitorais com dados de survey com amostras nacionais 28

1.4. Contexto socioeconômico das disputas presidenciais entre PSDB e PT no período de 1994 a $2006 \quad 33$

1.4.1. Macrotransformações socioeconômicas 33

1.4.2. Dados socioeconômicos da tese 36

1.5. Análise dos impactos eleitorais das características socioeconômicas dos eleitores nas eleições presidenciais no Brasil de 1994 até 2006

1.5. Sexo 39

1.5.2. Idade 40

1.5.3. Escolaridade $\quad 42$

1.5.4. Renda $\quad 45$

1.5.5. População economicamente ativa 46

1.5.6. Etnia 48

1.5.7. Religião $\quad 49$

1.5.8. Região $\quad 51$

1.5.9. Tipo de cidade $\quad 54$

1.6. Vista geral sobre os modelos socioeconômicos bivariados 55

1.7. Modelos logísticos com o conjunto de variáveis
socioeconômicas

1.8. Considerações finais 60

CAPÍTULO 2. MODELO PARTIDÁRIO E IDEOLÓGICO DE DECISÃO DE VOTO 62

2.1. Introdução 62

2.2. Partidos e ideologias na literatura internacional sobre $o$ comportamento eleitoral

2.3. Os partidos na decisão do voto no Brasil 72

2.3.1. Dados agregados na análise dos partidos na arena eleitoral 73

2.3.2. Dados de pesquisa de opinião na análise dos partidos na arena
eleitoral

2.4. Partidarismo na disputa presidencial entre PSDB e PT 84

2.4.1. Modelos logísticos para ocorrência de voto em PSDB e PT com preferência partidária 
2.4.2. Modelos logísticos para ocorrência de voto em PSDB e PT com avaliação dos partidos

2.5. Ideologia na decisão do voto no Brasil 93

2.5.1. Ideologia na disputa PSDB-PT 96

2.5.2. Modelos de regressão com ideologia 99

2.6. Combinando variáveis socioeconômicas com político-

$\begin{array}{ll}\text { ideológicas } & 101\end{array}$

2.6.1. Modelos de regressão com o conjunto de variáveis de longo 104 prazo

$\begin{array}{ll}\text { 2.7. Considerações finais } & 107\end{array}$

CAPÍTULO 3. MODELO RACIONAL DE DECISÃO DE VOTO 109

3.1. Racionalidade na decisão de voto 110

3.1.1. Avaliação de desempenho governamental 115

3.1.2. Avaliação de candidatos $\quad 117$

3.1.3. Avaliação de questões 120

3.2. Racionalidade e fatores de curto prazo na decisão de voto no Brasil

3.2.1. Avaliação de desempenho e voto presidencial no Brasil

3.2.2. Avaliação de candidatos e voto presidencial no Brasil 132

3.3. Análise do impacto das avaliações de governo nas eleições $\begin{array}{ll}\text { presidenciais brasileiras } & 136\end{array}$

3.3.1. Modelos de regressão com avaliação de governo 138

3.4. Análise do impacto das avaliações dos candidatos nas

eleições presidenciais brasileiras 141

3.4.1. Qualidades que um presidente deve ter 141

3.4.2. Capacidade dos candidatos para resolver os principais problemas $\begin{array}{ll}\text { do país } & 155\end{array}$

3.5. Considerações finais 159

CAPÍTULO 4. MODELOS GERAIS DE DECISÃO DE VOTO 162

4.1. Modelos gerais de regressão logística multivariados para $o$ $\begin{array}{ll}\text { PSDB } & 166\end{array}$

4.2. Modelos gerais de regressão logística multivariados para o PT 173

$\begin{array}{ll}4.3 \text { Considerações finais } & 180\end{array}$

$\begin{array}{ll}\text { CONCLUSÕES } & 181\end{array}$

$\begin{array}{ll}\text { REFERÊNCIAS } & 191\end{array}$ 


\section{Introdução}

O Brasil realiza eleições presidenciais com o voto direto de seus cidadãos desde o fim do século XIX. No total, já foram realizadas 27 eleições presidenciais no Brasil. O primeiro presidente da República eleito diretamente foi Prudente de Morais, que, em março de 1894, recebeu 276.583 votos, sete vezes mais que o segundo colocado.

Na República Velha foram 11 eleições, das quais somente quatro, em 1910, 1919, 1922 e 1930, envolveram uma disputa efetiva: todas as demais foram vencidas por larga margem pelo candidato governista. As restrições do sufrágio aos que possuíam certos níveis de renda e a fraude eleitoral foram a tônica das eleições ocorridas nesse período.

No decorrer de todo o governo Vargas, entre 1930 e 1945, ocorreu apenas uma eleição presidencial, decidida indiretamente na Assembléia Constituinte. Entre 1945 e 1960, aconteceram as quatro primeiras eleições presidenciais que combinaram como nunca antes a participação e a contestação política, em que partidos políticos antagônicos nacionalmente organizados se lançavam à disputa do voto de um grande contingente eleitoral, ainda que subsistissem barreiras importantes ao voto, como a exclusão dos analfabetos. No período seguinte, até 1985, todas as eleições presidenciais foram indiretas, com os presidentes eleitos ou pelo Congresso Nacional ou por Colégios Eleitorais. Só a partir de 1989 as eleições presidenciais voltaram a ser decididas pelo voto direto dos eleitores, a partir de então incorporando também os analfabetos.

Desde então, os cientistas políticos pesquisam o comportamento dos eleitores nas eleições presidenciais. Diversas teses e livros importantes, além de artigos em revistas especializadas e dissertações de mestrado, foram produzidos sobre o tema. Entre os trabalhos mais importantes, três devem ser destacados, porque são teses de doutoramento defendidas nas principais escolas de pós-graduação em ciência política do país e, em certa medida, estão filiadas às chamadas escolas do comportamento eleitoral. Referimonos aqui à tese da centralidade da sofisticação política (Castro, 1994), mais 
próxima da escola sociológica, à tese do voto ideológico (Singer, 2000), ligada à escola psico-sociológica, e a tese do voto econômico (Carreirão, 2002), próxima da teoria da escolha racional. O principal mérito desses trabalhos foi abrir caminho em um território ainda completamente inculto que era nosso conhecimento acadêmico sobre os processos eleitorais ao nível nacional. Seguindo a tradição metodológica estabelecida pelas escolas de Columbia e Michigan, os autores analisaram de dados de pesquisas quantitativas por amostragem e testaram algumas das hipóteses mais importantes do comportamento eleitoral. Isso estabeleceu um importante referencial teórico e empírico a partir do qual novas pesquisas puderam ser desenvolvidas. Sem dúvida, este trabalho é tributário desses pioneiros.

As principais fragilidades dessas teses residem no curto horizonte de tempo sobre as quais são construídas e na ausência de análises multivariadas. A tese de Castro analisa a eleição presidencial de 1989, Singer incorpora a de 1994 e Carreirão acrescenta a de 1998. Desde então, foram realizadas outras duas eleições presidenciais, o que possibilitou alargar em oito anos o período de análise. Além disso, atualmente os pesquisadores dispõem de maior quantidade e melhor qualidade de bancos de dados de pesquisas quantitativas realizadas junto aos eleitores brasileiros e referentes às eleições presidenciais. Esses dois aspectos contribuíram decisivamente para a definição do objeto e do método deste estudo, que é uma tentativa de superar aquelas fragilidades com a análise de quatro eleições presidenciais e o uso de várias técnicas multivariadas.

Este trabalho examina a série de eleições presidenciais brasileiras de 1994 até 2006, tendo como referência a disputa entre o Partido da Social Democracia Brasileira (PSDB) e o Partido dos Trabalhadores (PT). A idéia de estudar essas eleições surgiu logo após o início do doutorado, em meados de 2001 - quando, mais uma vez, se anunciava uma disputa presidencial que tinha como protagonistas os candidatos tucano e petista - começou a amadurecer durante o governo petista e, finalmente, se concretizou agora, depois da eleição de 2006, que repetiu o embate e foi uma nova reeleição.

A seqüência de quatro eleições presidenciais em que os mesmos dois partidos alcançaram pelo menos $70 \%$ dos votos válidos, que culminou em 
quase 90\% em 2006 e que estabeleceu transições políticas pacíficas é algo sem precedentes em nossa história republicana e por si só já justificaria a realização desta tese. Além dessas justificativas pessoal e histórica, também existe uma justificativa teórica, na medida em que é necessário entender como, a despeito de análises eivadas de pessimismo, o sistema partidário eleitoral caminhou rumo a uma disputa entre apenas dois partidos, com os demais gravitando à sua volta.

Para proceder à análise, vamos examinar um conjunto de variáveis agrupadas sob três perspectivas teóricas sugeridas pela literatura internacional e nacional sobre o tema.

A primeira perspectiva, derivada da escola sociológica de Columbia, reúne as variáveis referentes às condições de vida mais objetivas dos eleitores, as características demográficas e socioeconômicas, tais como sexo, idade, escolaridade, renda e região do país, entre outras. A segunda abordagem, inspirada na escola psico-sociológica de Michigan, adota variáveis referentes às posições partidárias e ideológicas dos eleitores. E o terceiro enfoque, que privilegia a teoria da escolha racional, abrange aspectos mais diretamente afeitos às campanhas eleitorais, notadamente as variáveis de curto prazo referentes à avaliação de governos e candidatos. A intenção é mostrar que os efeitos de longo prazo privilegiados nas duas primeiras abordagens são importantes, mas os de curto prazo têm maior impacto sobre as chances de o eleitor votar em um ou outro partido.

A pesquisa desenvolvida para a realização deste trabalho combinou intensamente a atividade teórica e a atividade empírica. Pelo lado da teoria, o instrumental analítico da ciência política para o estudo de eleições é amplo, marcado pela existência de três grandes escolas, as quais, embora divergentes, possuem diversos pontos em comum, razão por que diversos outros estudos procuraram combinar elementos de todas essas escolas. Para dar conta dessa complexidade teórica, é necessária uma base empírica sólida, capaz de permitir os testes das hipóteses sugeridas pela literatura, em especial considerando variáveis simultaneamente e os processos que ocorrem ao longo do tempo. Os bancos de dados de que dispomos permitem 
a realização desses testes, assim como fazer inferências sobre processos temporais com alguma segurança.

A tese está estruturada em quatro capítulos, além desta Introdução, do Preâmbulo metodológico e das Considerações finais.

O primeiro capítulo trata dos efeitos das características demográficas e socioeconômicas dos eleitores nas chances de voto para o PSDB e para o PT. Há diversos trabalhos que tratam do impacto dessas características no comportamento eleitoral. Desde sempre, vários trabalhos apontaram evidências de que tais efeitos existem, ainda que, com o passar dos anos essa abordagem tenha perdido terreno. A hipótese que permeia toda a literatura e que tratarei de testar é que aquelas condições são importantes para prever o comportamento eleitoral, ou seja, que importa conhecer as características demográficas e socioeconômicas dos eleitores para saber em quem eles votarão nas eleições presidenciais.

A literatura nacional sobre o tema é tradicionalmente marcada pela investigação dos efeitos que aquelas características exercem sobre o comportamento eleitoral. Contudo, essas análises também estão sendo substituídas por outros tipos de considerações. É notável a ausência de um estudo sobre 0 impacto que as características demográficas e socioeconômicas possam ter sobre as eleições presidenciais no Brasil atual, marcadas por um embate quase bipartidário, o que seguramente simplifica a disputa e sugere alguma polarização sociológica.

Na teoria política, os partidos e a ideologia também são vistos como elementos estáveis e de longo prazo para a decisão do voto. A vinculação social que se verificava em relação ao voto era muito semelhante à observada quanto à adoção de alguma identificação partidária ou posicionamento ideológico. Existia uma ligação clara e lógica que associava classes sociais aos partidos e ao voto. Tal associação geralmente era destituída de um conteúdo ideológico mais estruturado, capaz de formar um sistema de crenças afinado a um sistema de classes.

Tanto fora, como dentro do Brasil, os autores que analisam o papel de partidos e ideologia na decisão de voto tendem a concordar que os primeiros são mais importantes para a decisão e que as ideologias são em geral 
inconsistentes. Por um lado, faltava aos eleitores suficiente capacidade cognitiva para estruturar uma decisão política baseada em imperativos de tipo ideológico. Por outro, os partidos são as organizações que comandam os processos eleitorais e governamentais; assim, adquirirem certa notoriedade, inclusive entre os de mais baixo estrato social, porque estão constantemente presentes nos meios de comunicação de massa e nas campanhas eleitorais.

No segundo capítulo, focalizam-se os impactos exercidos pela preferência partidária, pelas opiniões acerca dos partidos políticos e pelas posições ideológicas adotadas pelos eleitores sobre as chances de voto no PSDB e no PT. A hipótese que tratarei de testar é que importa conhecer a posição partidária e ideológica do eleitor para prever seu comportamento eleitoral. Além disso, o capítulo se encerra com a consideração simultânea dos três conjuntos de variáveis de longo prazo analisados. Isto se justifica pelo fato de que, como diversos autores apontam, certas características políticas e ideológicas estão associadas a características demográficas e socioeconômicas, especialmente a educação. Essa consideração geral indica a persistência da significância de algumas variáveis socioeconômicas e da ideologia e a preponderância das variáveis partidárias para as chances de voto em tucanos e petistas.

O terceiro capítulo da tese traz uma análise dois conjuntos de variáveis classificadas na literatura como tendo efeitos de curto prazo na decisão de voto. As considerações sobre tais variáveis foram impulsionadas pelos trabalhos filiados a uma abordagem econômica do comportamento eleitoral, fundada na teoria da escolha racional e no individualismo metodológico, a partir do qual o debate deslocou-se das características socioeconômicas, partidárias e ideológicas dos eleitores e passou a se ocupar mais das avaliações de governo e de candidatos.

As avaliações de governo tornaram-se importantes para a análise da decisão de voto a partir dos trabalhos de Downs (1999) e Key (1966), que mostraram que tais avaliações são elementos centrais no cálculo que o eleitor faz para tomar sua decisão eleitoral, em particular quando está em jogo uma reeleição. As avaliações de candidatos ganharam força nessa área de estudo, principalmente a partir da década de 70 , quando estudos 
importantes, tais como o já citado de Key (1966) e os de Wattenberg (1991, 1998), passam a dar conta da visibilidade cada vez maior que os candidatos adquiriram nas disputas presidenciais. Com a proliferação dos meios de comunicação de massa, os candidatos presidenciais podem cada vez mais prescindir dos partidos políticos, antes os principais responsáveis pela disseminação da imagem do aspirante à Presidência e das propostas de sua candidatura. Atualmente, os presidenciáveis podem chegar ao vivo e simultaneamente na casa de todos os eleitores que possuem um aparelho de TV, dispositivo cada vez mais presente nos domicílios brasileiros. A análise sobre o papel dos candidatos gira em torno das opiniões dos eleitores sobre as principais qualidades que os postulantes ao cargo deveriam ter para ocupar a Presidência da República e sobre sua capacidade de resolver os principais problemas nacionais.

A hipótese que tratarei de testar é que conhecer a avaliação que os eleitores fazem dos governos e dos candidatos é o aspecto mais determinante do comportamento eleitoral nas eleições presidenciais brasileiras. Além disso, no quarto capítulo é analisado o impacto exercido por todas as variáveis, tanto as de longo, como as de curto prazo, simultaneamente. A hipótese principal é que o conjunto de variáveis de curto prazo tem maior poder explicativo e preditivo sobre o comportamento eleitoral que o de variáveis de longo prazo.

Após o exame desses conjuntos de variáveis, que reúnem todas as que foram tratadas na literatura, propomos um modelo de voto para o PSDB e para o PT que reúne as mais significantes para explicar o comportamento eleitoral e prever a probabilidade que um eleitor tem de votar em um ou outro partido. Nesse modelo, o que se busca é a parcimônia, a obtenção de máximo poder explicativo e preditivo com o mínimo de covariáveis possível. Procuramos demonstrar que as avaliações dos candidatos são as variáveis que melhor explicam o voto no período estudado, mas que aspectos como preferência partidária e avaliação do governo não devem ficar ausentes de um modelo que busque a compreensão do comportamento dos eleitores frente às urnas e de como PSDB e PT dominaram a arena eleitoral presidencial por tantos anos. 
Todos os capítulos, exceto o quarto, terão estrutura semelhante. São iniciados por uma revisão da literatura internacional e nacional; a partir dessa revisão, fazemos algumas considerações sobre as conjunturas eleitorais entre 1994 e 2006 e, à luz das teorias e dos fatos, analisamos os dados que temos disponíveis para tratar de verificar as hipóteses relacionadas. 


\section{Preâmbulo metodológico}

As análises de dados serão feitas com o recurso a regressões logísticas. ${ }^{1}$ Os métodos de regressão tornaram-se centrais em qualquer análise de dados concernente à descrição da relação entre uma variável de resposta e uma ou mais variáveis explanatórias. O exemplo mais comum de modelagem estatística é o modelo de regressão linear em que a variável resposta é contínua. Em muitos casos, porém, a variável dependente é discreta, assumindo dois ou mais valores possíveis. Assim, nas últimas décadas, o modelo de regressão logística tem se tornado, em diversas áreas do conhecimento, o método padrão de análise nesses casos. ${ }^{2}$

O objetivo da análise com o uso da regressão logística é o mesmo que qualquer outro tipo de modelagem estatística: encontrar o melhor ajuste e a maior parcimônia em um modelo teoricamente razoável para descrever a relação entre um resultado, a variável dependente ou de resposta, e um conjunto de variáveis independentes, ou preditoras, ou explicativas, ou ainda covariáveis.

O que distingue o modelo de regressão logística do modelo de regressão linear é que a variável resposta da regressão logística é binária ou dicotômica. Além disso, é a distribuição binomial, não a normal, que descreve a distribuição dos erros e sobre a qual se baseia a análise. De forma geral, os princípios que regem a análise de regressão linear são os mesmos que nos guiam na regressão logística.

Por convenção, os resultados de uma regressão logística são geralmente descritos como sucesso ou fracasso. Em geral, o resultado substantivo é considerado sucesso $(\mathrm{y}=1)$ e o seu complemento é considerado fracasso $(\mathrm{y}=0)$. O modelo logístico é especialmente apropriado quando a

\footnotetext{
${ }^{1}$ Existem diversos manuais de análise de dados que tratam de regressões logísticas. Neste trabalho, as principais referências são Hosmer \& Lemeshow (1989) e Powers \& Xie (2000).

${ }^{2}$ Exemplos interessantes do uso das regressões logísticas na ciência política brasileira podem ser encontrados nos artigos de Carreirão \& Barbetta (2004) e de Kinzo (2005), bem como na tese de Moya (2005).
} 
questão de interesse é descrever as chances de sucesso de algum fenômeno. O conceito de chance pode ser estendido para descrever as chances de sucesso associadas ao pertencimento a um grupo em oposição a outro. Neste caso, a medida é a razão de chance, que nada mais é do que as chances de sucesso de um grupo em relação a outro grupo. A interpretação mais adequada das regressões logísticas é a que utiliza essa medida. Se dois grupos têm a mesma chance de sucesso, a razão de chance é igual a 1. Uma razão de chance igual a 2 indica que a chance de sucesso de um grupo é o dobro da do grupo de referência, mantidas as demais variáveis constantes; a razão de chance igual a 0,5 indica que a chance de sucesso de um grupo é a metade da do grupo de referência, sempre mantidas as demais variáveis constantes.

Para aferir a qualidade do modelo na regressão linear, habitualmente se apresenta o coeficiente de determinação $\mathrm{R}^{2}$, cujo valor está no intervalo entre 0 e 1. Esse coeficiente representa a proporção da variância da variável dependente que é explicada pelas covariáveis. Na regressão logística, não há um coeficiente com esta interpretação, uma vez que não existe uma reta que melhor represente os dados; mas existem opções de generalizações do coeficiente $\mathrm{R}^{2}$ em que, quanto maior o seu valor, maior é o poder explicativo do modelo com os dados da amostra. No caso do $\mathrm{R}^{2}$ proposto por Nagelkerke, utilizado nesta tese, o resultado estará sempre no intervalo de 0 a 1. Dessa forma, quando o $\mathrm{R}^{2}$ é igual a zero, o modelo não é adequado e não explica nada da variância observada da variável dependente. Em caso de $\mathrm{R}^{2}$ igual a 1 , o modelo é capaz de explicar integralmente toda a variância da variável dependente.

Outra maneira de avaliação da qualidade do modelo é considerar sua capacidade de predizer corretamente a variável dependente. Neste caso, quando a chance de sucesso prevista pelo modelo for maior que $0,5,0$ modelo prevê o sucesso. A partir disso, são comparados os resultados previstos pelo modelo e os observados na amostra: quanto maior a proporção prevista de modo correto, melhor o ajuste ou a qualidade do modelo. No caso do tema deste trabalho, isso possibilita que o modelo seja utilizado no cálculo das probabilidades ou chances que um eleitor tem de votar no PSDB ou no 
PT. Dessa forma, será possível encontrar uma combinação de elementos que elevem ao máximo o índice de acerto do modelo, de previsões corretas das intenções de voto, proporcionando ainda que sejam identificados quais aspectos são mais determinantes para o comportamento eleitoral.

Finalmente, para encerrar esse preâmbulo metodológico, é necessário discorrer sobre os dados que serão utilizados no trabalho. Com relação a esse aspecto, existe grande limitação de trabalhos de cunho eminentemente acadêmicos. Com efeito, são escassas as pesquisas qualitativas ou quantitativas sobre o comportamento político brasileiro disponíveis para os que estudam a questão. As universidades, tanto as públicas, como as particulares, as agências de fomento e os órgãos governamentais investem poucos recursos na realização de estudos com esse objetivo - quando investem algo. As mais importantes pesquisas quantitativas com amostra representativa do conjunto de eleitores no Brasil foram realizadas em 2002/2003: trata-se do Estudo Eleitoral Brasileiro (Eseb) e da Pesquisa Social Brasileira (Pesb), realizadas pela Universidade Federal Fluminense (UFF), com apoio do Centro de Estudos de Opinião Pública (Cesop) da Universidade Estadual de Campinas (Unicamp) e com financiamento da Coordenação de Aperfeiçoamento de Pessoal de Nível Superior (Capes) e da Fundação Ford. Também em 2002, desta vez pelo Departamento de Ciência Política da Universidade de São Paulo (DCP-USP), com financiamento da Fundação de Amparo à Pesquisa do Estado de São Paulo (Fapesp), foi realizada uma pesquisa com os eleitores da Grande São Paulo com vistas a compreender melhor o papel dos partidos políticos na estruturação da disputa eleitoral. Isso significa que, para compreender a disputa eleitoral entre PT e PSDB pela Presidência da República entre 1994 e 2006, torna-se obrigatória a utilização de bancos de dados resultantes de pesquisas de opinião quantitativas levadas a cabo por institutos de pesquisa não acadêmicos.

Nesse trabalho, além de utilizar os dados das pesquisas acadêmicas a que já nos referimos, utilizaremos levantamentos feitos pelo Datafolha em 1994, pelo Vox Populi em 1998, pela Ipsos Opinion em 2002 e pela Analítica Consultoria em 2006. Utilizar dados de pesquisas de institutos de opinião pública representa um risco, uma vez que foram planejadas para serem 
divulgadas na imprensa ou para orientar campanhas eleitorais. Contudo, essas bases de dados foram construídas com o mesmo rigor metodológico que se exige das pesquisas acadêmicas. Além disso, esses dados estão disponíveis para os pesquisadores, algo que muitas vezes não ocorre quando uma pesquisa é realizada em universidades. Se estas não produzem o conhecimento necessário para o desenvolvimento científico, o mundo privado pode ser um parceiro importante nessa empreitada, na mesma medida em que foi e continua sendo nos Estados Unidos e na Europa.

As amostras dos bancos de dados do Datafolha, da Vox Populi, da Ipsos Opinion e da Analítica Consultoria foram selecionadas a partir de sorteios sucessivos proporcionais ao tamanho de cidades, setores censitários e ponto amostral e estratificadas por cotas de sexo, idade e instrução. O Estudo Eleitoral Brasileiro teve amostra selecionada de forma probabilística em três estágios de seleção: município, setor censitário e domicílio. Os tamanhos das amostras variaram entre 1.000 e 3.000 casos, todas suficientes para proporcionar maior segurança nas inferências.

Todos os levantamentos foram feitos com auxílio de questionários estruturados aplicados pessoalmente por entrevistadores treinados em pontos de fluxo ou em domicílios, no caso do ESEB. Como os questionários foram elaborados por diferentes pesquisadores e profissionais, em muitas vezes, os conceitos são operacionalizados e medidos de maneiras diferentes. $\mathrm{Na}$ medida do possível este trabalho buscou adotar as mesmas medidas. As variáveis dependentes são sempre a intenção de voto no PT e no PSDB e as variáveis dependentes mais importantes, escolaridade, identificação partidária, avaliação do governo e dos candidatos são medidas de forma muito semelhante. A principal exceção é a ideologia, que em cada eleição foi medida de forma diferente.

Mesmo considerando que as pesquisas realizadas pelas empresas e acadêmicas foram realizadas com diferentes formas de seleção da amostra e diferentes questionários, é possível testar com alguma segurança hipóteses que envolvam processos ao longo do tempo.

As hipóteses teóricas e suas operacionalizações empíricas foram testadas estatisticamente. Os testes de hipóteses são apresentados nos 
quadros que apresentam as razões de chance, os R2, e os percentuais de acerto. Essas estatísticas nos permitem observar o comportamento de cada variável no modelo, a razão de chance, a capacidade explicativa do modelo, o R2, e a capacidade preditiva, os percentuais de acerto. Em alguns modelos, especialmente os bivariados, as razões de chance são significantes, mas a capacidade explicativa e preditiva do modelo são baixas. Nessas situações, julgou-se conveniente apresentar os modelos para que os achados sejam documentados. 


\section{Capítulo 1. Modelo sociológico de decisão de voto}

\subsection{Introdução}

Desde os primeiros trabalhos de análise do comportamento eleitoral, sempre se levaram em consideração as características demográficas e socioeconômicas dos eleitores. Nos primórdios, antes da década de 40, os estudos apresentavam uma análise ecológica dos votos, examinando resultados eleitorais de pequenas regiões, cidades ou estados e tendo como suporte dados censitários. Dessa forma, foi possível detectar, com base em dados agregados, importantes fatores relacionados ao voto, como religião, local de moradia e status socioeconômico.

A partir dos anos 40, os pesquisadores da Universidade de Colúmbia mudaram o método de pesquisa e passaram a utilizar dados de pesquisas de opinião, com os quais era possível a análise dos eleitores ao nível individual. Até hoje, esse método de pesquisa é o mais utilizado nas análises do comportamento político. Ainda que o método tenha permanecido, a chave socioeconômica para a compreensão dos resultados das eleições começou a perder terreno a partir dos anos 60, quando ganhou força uma nova corrente, mais preocupada com aspectos psicológicos e cognitivos como a identificação partidária e ideológica.

No Brasil, a vertente socioeconômica manteve seu vigor até o início dos anos 90, quando novas teorias para o estudo do comportamento eleitoral foram incorporadas por nossos analistas. Esse arejamento, porém, não foi suficiente para que estes deixassem de considerar as condições de vida mais objetivas dos cidadãos. Diferenças no comportamento entre mulheres e homens, entre os menos e os mais escolarizados e regionais ainda continuam presentes nos trabalhos realizados pelos que se interessam pela temática.

Como veremos, a disputa entre o PSDB e o PT pela Presidência da República está relacionada a variáveis socioeconômicas. Faz diferença saber se o eleitor é homem ou mulher, qual é o seu nível de escolaridade e onde mora, para inferir qual é a chance de que vote em um dos dois partidos nas eleições que protagonizaram. 
Neste capítulo, construímos modelos probabilísticos para a decisão de voto no PSDB e no PT, tendo como variáveis independentes as características demográficas e socioeconômicas dos eleitores. Antes, porém, é necessária uma revisão da literatura internacional e nacional que nos dê o embasamento teórico que norteará a análise empírica.

\subsection{A abordagem sociológica do comportamento eleitoral na literatura internacional}

As eleições são um dos pontos altos dos regimes políticos, especialmente dos democráticos. Desde que o sufrágio passou a ser estendido a parcelas cada vez maiores da população, aumentou o interesse de todos os que acompanham de perto a política sobre como as pessoas votam e por que tomam as decisões que tomam dentro da cabine eleitoral.

Os primeiros estudos a respeito ocorreram ainda no século XIX. Alguns dos mais importantes trabalhos desse período foram realizados na GrãBretanha e publicados nas revistas da Sociedade de Estatística de Londres (cf. Martin, 1874, e Newmarch, 1857). Nessas obras, os dados eleitorais eram organizados por partido ou região, sempre a partir de agregados populacionais. Essa estratégia analítica permitia uma medida da distribuição das cadeiras no Parlamento, tendo em conta aspectos demográficos e socioeconômicos como o tamanho dos distritos, a taxa de pobreza, a renda média e a posição profissional. Uma das preocupações mais centrais era entender os efeitos causados nas eleições pela incorporação de novos contingentes de eleitores. Também nos EUA foram realizadas análises ecológicas dos votos, as quais chegaram às mesmas conclusões que as britânicas.

Os estudos mais detalhados sobre as motivações das decisões individuais de voto são mais recentes. Só com o desenvolvimento das pesquisas de opinião e dos sistemas de processamento de dados, a partir principalmente da década de 50, é que se tornou possível obter informações sobre os processos individuais de tomada de decisão eleitoral. Em seus primórdios, o estudo do comportamento eleitoral esteve muito vinculado a uma abordagem sociológica. A principal clivagem social que orienta os trabalhos, tanto nos EUA, como na Europa, é a de classes. A idéia de fundo é que os partidos haviam se 
organizado em bases sociais distintas, e que essas diferenças refletiam-se fortemente na maneira como eleitores de diferentes estratos sociais comportavam-se politicamente, ou seja, o sistema partidário e o comportamento eleitoral refletiam as clivagens existentes na sociedade.

Os primeiros trabalhos importantes nessa linha de pesquisa, que combinava análise sociológica com dados de pesquisa quantitativa para buscar compreender o comportamento político, foram os organizados pelos pesquisadores da Universidade de Colúmbia. Como exposto em The People's Choice (Lazersfeld, Berelson \& Gaudet, 1948) e em Voting (Berelson, Lazarsfeld \& McPhee, 1954), existiria forte impacto social sobre as decisões políticas.

Já era consensual nos EUA de então o reconhecimento da existência de diferenças sociais claramente perceptíveis entre democratas e republicanos. Os autores confirmam essa idéia, mostrando que, quanto maior o nível socioeconômico, maior a proporção de intenção de voto nos republicanos; mostram também que a religião é outra variável importante, já que, independentemente do nível socioeconômico, os católicos são, em escala majoritária, democratas. Outros aspectos importantes são as maiores proporções de republicanos no meio rural e entre as mulheres.

Consideradas em conjunto, três das variáveis — nível socioeconômico, religião e local de residência - formam um índice de predisposição política (IPP) altamente correlacionado com a intenção de voto. No nível 1, estão eleitores da classe $A$, protestantes e moradores da área rural, fortemente inclinados ao voto nos republicanos; no extremo oposto, no nível 7, estão eleitores de classe $D$, católicos e da zona urbana, fortemente propensos a eleger democratas; à medida que se passa do nível 1 ao 7 , a proporção de republicanos diminui de $74 \%$ para $17 \%$. Com esses dados em mãos, os autores chegam a afirmar categoricamente que características sociais determinam as preferências políticas.

Para eles, a votação é essencialmente uma experiência de grupo e os indivíduos que trabalham, vivem ou se divertem juntos tendem a votar em um mesmo candidato. Mais que isso, indivíduos a quem corresponde aproximadamente o mesmo IPP tendem a se unir socialmente, o que leva os grupos a uma uniformidade de idéias e comportamento político. Esse aspecto 
torna-se mais evidente com a constatação de que a maioria dos eleitores que mudou de idéia em relação ao voto seguiu a inclinação política predominante de seu grupo social. Um dos fatores de pressão social sobre o voto mais forte nos EUA dos anos 40 era a família, principalmente para jovens e mulheres.

A filiação a associações formais da sociedade também está relacionada ao comportamento eleitoral e ao enquadramento do eleitor na linha de seu partido, isto é, a incompatibilidade entre opiniões e voto é menor entre aqueles eleitores filiados a associações. Essa linha de investigação foi mais desenvolvida pelos autores de Voting (Berelson, Lazarsfeld \& McPhee, 1954), os quais, além de considerarem as questões socioeconômicas, focalizam em sua análise instituições da sociedade como sindicatos, partidos políticos e outras organizações formais. A conclusão a que chegam é que os eleitores sindicalizados tendem em direção ao Partido Democrata e que quanto mais tempo estão filiados e mais freqüentam o sindicato, maior o vínculo com essa agremiação partidária. No entanto, os autores não creditam esse posicionamento ao sindicato enquanto organização, mas à interação entre as pessoas que o ambiente sindical possibilita. Em poucas palavras: a escola sociológica de Colúmbia defende a idéia de que os eleitores não votam apenas com o seu grupo, mas também para o seu grupo e que a decisão de voto é uma experiência social.

Os primeiros estudos na Europa que seguiram a mesma abordagem teórica e metodológica da escola de Colúmbia foram realizados na GrãBretanha. Em How People Vote (Benney, Gray \& Pear, 1956) e em Marginal Seat (Milne \& MacKenzie, 1958), são examinadas informações sobre o comportamento dos eleitores nas localidades de Greenwich e Bristol, coletadas ao longo da campanha em uma pesquisa tipo painel. Os achados desses autores britânicos reforçam os obtidos nos EUA, principalmente no que diz respeito às características socioeconômicas dos eleitores, dentre as quais o sexo, a religião, o pertencimento a grupos, a condição social e, em especial, a consciência de classe, questão importante na Grã-Bretanha. A diferença central entre os estudos norte-americanos e ingleses é que os primeiros ocupavam-se das eleições presidenciais, enquanto os últimos tratavam de eleições para deputado, dado que o sistema britânico é parlamentarista. 
Diversos estudos entre os anos 50 e 60 deram ênfase à influência que as diferenças sociais exerciam sobre as opções políticas. Dentre eles, Political Man (Lipset, 1981) foi um dos mais influentes, porque explicitou um caráter classista na disputa eleitoral nas democracias ocidentais. A clivagem social, a diferença entre ricos e pobres, o status, a renda, o pertencimento aos sindicatos de trabalhadores, a religião, tudo gerava impacto sobre a decisão sobre a posição política a adotar. Os trabalhadores, os pobres e os sindicalizados, entre outros, ficavam ao lado dos partidos socialistas, trabalhistas e comunistas, confessionais; a classe média e alta alinhava-se mais aos partidos liberais e conservadores. A disputa político-partidária tentava enquadrar em moldes democráticos o embate entre dois pólos que marcavam claramente suas fronteiras.

Voltado para o contexto europeu, o estudo de Lipset \& Rokan (1967), que trata dos sistemas partidários e dos alinhamentos eleitorais, mostra que os partidos e as eleições continuavam a ter um padrão classista. Sem dúvida, países com antagonismos de classe mais presentes, como a Inglaterra, a França e a Alemanha, continuaram a ter disputas políticas enquadradas nesse esquema. Em comparação com os EUA, as forças sociais exerciam uma influência maior sobre as decisões eleitorais nas disputas européias.

A partir dos anos 60, as análises começam a matizar a centralidade da clivagem social sobre o comportamento político. Isso não implicou, contudo, no abandono do exame do impacto das variáveis demográficas e socioeconômicas, as quais, pelo menos as mais importantes, continuavam a fazer sentido político e eleitoral. Assim é que, em The American Voter (Campbell et al., 1960), os autores atribuem à identificação partidária o papel de filtro para informações e idéias, determinante na maneira como os eleitores avaliam os candidatos e as questões políticas. Não deixam, porém, de abordar os elementos que compõem a realidade social. Eles consideram que a noção de pertencimento a grupos sociais exerce uma pressão psicológica que pode afetar o comportamento político. Muitas vezes, os grupos ou seus representantes são pontos de referência para a formação de atitudes e de decisões políticas. Assim, em alguma medida, suas manifestações sempre 
influenciam, positiva ou negativamente, o modo como seus membros avaliam o mundo da política.

Os autores também investigam o papel das classes sociais no comportamento eleitoral. Diferentemente de outros grupos, as classes sociais nos EUA raramente se organizam de maneira formal ou possuem lideranças ou porta-vozes, mesmo que informais. Apesar disso, na cabeça de muitos eleitores, a classe pode ter uma realidade psicológica como grupo. Isso depende, até certo ponto, da consciência de classe. Tanto Marx, quanto Weber acreditavam que as diferenças classistas surgiam inevitavelmente dos fatos da ordem econômica e não existiriam como tal enquanto não surgisse um sentimento, uma identificação de classe, entre seus potenciais membros. Uma das condições para o surgimento da identificação é a polarização entre as classes, que sempre foi fraca nos EUA.

Existem outros aspectos demográficos, sociais ou econômicos que são importantes para a compreensão do comportamento político, segundo Campbell et al., (1960). A escolaridade, o sexo e a idade do eleitor, características sem vinculação a grupos, importam quando se analisam aspectos como o comparecimento às urnas, o envolvimento na política, a identificação partidária e os níveis de conceitualização.

Assim como ocorrera com os trabalhos da escola de Colúmbia, a agenda de pesquisa teórica e metodológica da escola de Michigan foi utilizada para a realização de uma série de trabalhos sobre as eleições na GrãBretanha, conduzidos por Butler e Stokes entre os anos de 1963 e 1970. A principal publicação da dupla foi Polítical Change in Britain (Butler \& Stokes, 1969). Assim como nos EUA, o foco da análise recai sobre os alinhamentos partidários. O padrão britânico de competição partidária transforma-se ao longo do século XX, com o crescimento das preferências eleitorais pelos trabalhistas e com a decadência dos liberais. Os autores procuram investigar as causas da expansão trabalhista e também da manutenção da força eleitoral dos conservadores. O Partido Trabalhista cresceu de uma forma quase natural, uma vez que os novos contingentes de trabalhadores ingressavam na cidadania sem os antigos laços liberais e passavam a apoiá-lo. Para os autores, as pessoas podem nem sempre votar com o partido com o qual se 
identificam, porém, ainda assim mantêm um compromisso partidário de longo prazo, que funciona como uma força estabilizadora nos padrões de voto ao longo do tempo. Na Grã-Bretanha, as classes eram claramente o principal fator, em um modelo de voto baseado em posições sociais. Lá, conservadores e trabalhistas conquistaram a maioria dos votos e dominaram as classes altas, médias e trabalhadoras. Essa ligação entre classes e partidos emprestou ao modelo de identificação partidária um apelo bem intuitivo. O estudo também penetrou fundo nos sucessivos níveis da escolha partidária, procurando desvendar o labirinto de influências exercidas por características socioeconômicas tais como idade, sexo, religião e região.

Mais recentemente, muitos pesquisadores, entre os quais Dalton (1984), Dalton \& Wattenberg (1993) e Inglehart (1990), têm indicado alterações nos padrões de comportamento eleitoral que acompanham mudanças nas sociedades ocidentais.

Knutsen (2006) estudou o voto classista em oito países da Europa Ocidental desde os meados dos anos 70 até o final dos anos 90 . Ele encontrou um declínio médio superior a $36 \%$ no voto baseado em quatro classes sociais. O declínio foi maior nos países em que anteriormente o esquema classista era mais forte, como Alemanha, Holanda e Grã-Bretanha. Todas as democracias ocidentais industriais compartilharam intenso processo de crescimento econômico no pós-guerra que levou a uma transformação nas formas de produção, a um aburguesamento dos trabalhadores e dissipou as diferenças nas formas de vida entre as classes sociais, atenuando a importância de conflitos políticos baseados em linhas de classe.

As conseqüências dessas mudanças sociais para a teoria sociológica do voto são claras, especialmente no que diz respeito às clivagens de classe. Existe uma tendência de declínio do voto classista que é encontrada em quase todas as democracias - nos EUA, na Europa e também no Brasil. Isso representa certo paradoxo, que pode ser explicado pelo enfraquecimento das ideologias opostas ao liberalismo político e econômico, uma vez que as diferenças entre as classes continuam a afetar as condições de vida dos eleitores. De qualquer forma, o que se observa é uma atenuação da ligação específica entre classes sociais e política eleitoral. 
Outra clivagem social contemporânea importante é a religião. Desde que os autores da Universidade de Colúmbia chamaram a atenção para a importância dessa variável, diversos autores a investigaram. Alguns (como Rose \& Urwin, 1969) chegam mesmo a afirmar que divisões religiosas, não de classes, constituem atualmente a principal base social dos partidos ocidentais. Isso parece fazer algum sentido quando observamos a emergência política dos evangélicos nos EUA e no Brasil.

Em The New American Voter (Miller \& Shanks, 1996), os autores denominam as estáveis características socioeconômicas como "não políticas". Tais características já haviam deixado de ser consideradas como as causas do comportamento eleitoral. Ainda assim, para estes pesquisadores, pessoas em categorias sociais e econômicas diferentes adotam distintas posições políticas como resultado de suas experiências sociais. Utilizando técnicas de análise multivariada de dados, eles mostram que os atributos sociais e econômicos já utilizados para explicar as posições políticas continuam relevantes como eram anos atrás. Do conjunto de variáveis analisadas, as condições socioeconômicas, a raça, o pertencimento a sindicatos e, principalmente, a religião, são clivagens que continuam a modelar as decisões de voto contemporâneas.

Alguns estudos com base na geografia do voto realizados na GrãBretanha (cf. Johnston et al., 1988, e Miller, 1977) relataram diferenças nos padrões eleitorais dos distritos de acordo com aspectos demográficos e socioeconômicos diversos, como classe, região, religião e desemprego, entre outros. Nesses estudos, as variáveis que medem algum tipo de posição social continuam sendo vistas como importantes, sob a perspectiva da análise de dados agregados ao nível do distrito e não individual.

Apesar dessa continuidade apontada por autores norte-americanos e britânicos, o declínio de voto baseado em clivagens sociais é aparente, não apenas com relação à religião e à classe social, mas também quanto à dicotomia rural-urbano. A intensa urbanização que se viu na maioria dos países ocidentais e o aburguesamento do homem do campo diminuíram consideravelmente a distância entre este e o da cidade. 
Outro aspecto que deixou de ter a mesma relevância foi a diferença de sexo. Ao tempo da emergência da escola sociológica, as mulheres estavam recém-integradas ao mundo da política e ainda seguiam de perto o comportamento de seus pais ou maridos, algo que não existe mais. Ademais, concomitantemente com a independência financeira, as mulheres conquistaram a independência política.

$\mathrm{Na}$ literatura internacional, em suma, a posição das variáveis socioeconômicas em um modelo de decisão de voto é variável. Por um lado, diversos autores defenderam e defendem a importância dessas variáveis. Por outro, novas linhas de pesquisa apontam para o declínio das explicações sociológicas do voto. Para muitos, a velha ordem social já não consegue dar conta da complexa realidade em que vivemos. A ampliação do discurso para atender às novas demandas da agenda política e a crescente exposição a outras fontes de informação, especialmente a mídia eletrônica, erodiram os valores que embasavam os conflitos sociais e orientavam a escolha eleitoral.

De qualquer forma, isso não significa que as clivagens sociais tornaramse completamente irrelevantes. Apenas perderam força explicativa para o entendimento do comportamento do eleitor, algo que foi intensificado com o obscurecimento das imagens partidárias. As mudanças estão dando um fim às simples estruturas de clivagens sociais que outrora enquadravam a competição partidária e proporcionavam a muitos eleitores um caminho fácil na tomada de suas decisões eleitorais. Contudo, as diferenças sociais não se extinguiram e devem continuar a influenciar os resultados políticos, em especial nos países com grande desigualdade social, como o Brasil.

\subsection{A abordagem socioeconômica da decisão do voto no Brasil}

As pesquisas realizadas no Brasil para explicar o comportamento eleitoral são fortemente marcadas pela escola sociológica. A hipótese geral presente em quase todas é que as características demográficas e socioeconômicas dos eleitores influenciam os resultados eleitorais. Os primeiros trabalhos importantes foram realizados entre as décadas de 50 e 70 e continham dados eleitorais e censitários agregados. Procurava-se mostrar que aspectos demográficos e socioeconômicos gerais, como os índices de 
urbanização e industrialização, estavam relacionados com o comportamento do eleitor.

A partir dos anos 70 , os pesquisadores passam a utilizar dados de pesquisa quantitativa, mantêm a perspectiva sociológica e incorporam a escola psicológica de análise. Características e opiniões pessoais dos eleitores passam a ser conhecidas ao nível individual, abrindo-se amplas possibilidades analíticas.

Apesar das diversas pesquisas realizadas, ainda não existem estudos que utilizem dados de pesquisas quantitativas para estudar o impacto das condições socioeconômicas sobre o comportamento eleitoral no Brasil ao longo do tempo. Além disso, a disputa entre PSDB e PT pela Presidência da República que marcou as quatro últimas eleições presidenciais ainda não foi investigada sob o ponto de vista das possíveis clivagens sociais que nela se refletiram. Como visto na seção anterior, há estudos que mostram os efeitos das variáveis classes, sexo, etnia, região e religião sobre a decisão de voto. $\mathrm{Na}$ literatura nacional, esta abordagem está ainda pouco explorada. Um dos objetivos desta tese é contribuir para definir sua importância no contexto eleitoral brasileiro. A pergunta central é: existem bases sociais de PSDB e PT no eleitorado brasileiro?

A resposta para essa pergunta exige que investiguemos como as características socioeconômicas dos eleitores foram consideradas nos trabalhos sobre o comportamento eleitoral no Brasil. Nessa perspectiva, esta seção tem três partes: a primeira trata dos autores que analisam resultados eleitorais agregados; em seguida, vêm os que utilizam pesquisa de opinião ao nível subnacional; por fim, os que analisaram pesquisas de opinião ao nível nacional.

\subsubsection{Geografia do voto}

A abordagem mais perene no Brasil é a que trata da geografia do voto. O pioneiro é o trabalho de Simão (1956), que analisa as eleições legislativas de 1947 na cidade de São Paulo, dando atenção especial ao eleitorado operário, que representava mais de um terço do total dos eleitores da cidade no final da década de 40. O autor identifica quatro zonas eleitorais operárias 
paulistanas. Na primeira, viviam $68,5 \%$ dos eleitores operários da cidade. Nas zonas 2 e 3, a ampla maioria dos eleitores era operária (67\% e 65\%, respectivamente) e compunha $12 \%$ do total de eleitores operários. Na zona 4 , finalmente, $38 \%$ do eleitorado eram operários e estes representavam 1,2\% do total da cidade. Os dados eleitorais obtidos por Simão sugerem ter havido uma correlação entre a composição profissional do eleitorado e as votações recebidas pelo Partido Comunista Brasileiro (PCB) - então Partido Comunista do Brasil - e pelo Partido Trabalhista Brasileiro (PTB). A correlação foi mais forte com o PCB na área 1 (uma área operária mais antiga) e com o PTB nas áreas 2, 3 e 4 (áreas de ocupação mais recente). Além dos dados eleitorais, o autor realizou diversas entrevistas com operários na cidade, chegando a duas conclusões: o voto operário orientou-se predominantemente para o PCB e o PTB; o voto industriário tendeu mais acentuadamente para o PCB do que para o PTB. Nessas condições, em poucas palavras, seria perfeitamente plausível se falar em um voto classista.

Os trabalhos de Ferreira (1960 e 1964), sob a mesma ótica, em um exame de todo o estado de São Paulo, chegam a conclusões que se assemelham às de Simão. Assim, este autor sugere a existência de vinculações socioeconômicas entre as diversas regiões paulistas e o sistema partidário-eleitoral. Agregando os dados das eleições por região do estado, Ferreira verifica a associação entre regiões industrializadas e voto nos partidos trabalhistas e reformistas e regiões não industrializadas e voto nos liberais e conservadores. Como o estudo focaliza o estado de São Paulo em um período marcado por forte presença das personalidades políticas de Ademar de Barros e Jânio Quadros, Ferreira também observa ligações socioeconômicas na distribuição do apoio político a essas lideranças populistas; no entanto, tais conexões não são rígidas, uma vez que a cada eleição mudavam as bases eleitorais dos líderes políticos.

Em um estudo de âmbito nacional, Soares (1973) analisa os resultados eleitorais de 1945 a 1962. Para ele, o aumento no "número de pessoas habilitadas a votar cuja posição na infra-estrutura econômica predispõe ao voto de esquerda, seja trabalhista, reformista ou comunista" (Soares, 1973, p. 60), levaria inevitavelmente ao crescimento eleitoral desses partidos, o que fora 
interrompido com o golpe militar de 1964. O autor observa que a crescente entrada de novos eleitores durante o período fortaleceu os partidos trabalhistas e reformistas. Constata também nítida correlação entre indicadores de desenvolvimento socioeconômico e o sufrágio nos partidos, de forma que, com o aumento das taxas de urbanização e de alfabetização e da renda per capita, os votos dados ao PCB e ao PTB aumentam, enquanto os do Partido Social Democrático (PSD) e da União Democrática Nacional (UDN) diminuem.

Outro aspecto salientado pelo autor foi a divisão do Brasil em regiões distintas quanto ao desenvolvimento econômico. Em sua ótica, existiriam dois países: o sudeste do País, desenvolvido, e o resto, que é subdesenvolvido. Essas diferenças regionais tinham conseqüências políticas que se evidenciavam na participação eleitoral e na força relativa dos partidos trabalhistas e reformistas, sempre maiores na área desenvolvida. Ele procura mostrar que "atrás do caráter aparentemente individual de muitas decisões políticas como a de votar em um partido, há uma infra-estrutura socioeconômica que as sobredetermina" (Soares, 1973, p. 215).

Muitos outros trabalhos com essa mesma abordagem foram realizados na cidade de São Paulo, seguindo o caminho aberto por Simão. Lamounier (1978 e 1983) analisa as eleições paulistanas, agrupando os resultados por áreas definidas por critérios socioeconômicos. Para este autor, a maior ou menor concentração de votos de um candidato ou partido em determinadas áreas pode ser uma indicação de maior ou menor apoio entre diferentes camadas sociais. Lamounier observa que o número de votos no partido do governo para cada voto no partido de oposição declinava sistematicamente na passagem das áreas mais ricas para as mais pobres - o que evidenciaria claramente a existência de uma relação entre condições de vida e comportamento eleitoral.

Outros trabalhos que se detiveram sobre o voto na cidade de São Paulo foram os de Pierucci (1987 e 1989) e de Pierucci \& Lima (1991 e 1993). O principal foco é o eleitorado que se posiciona à direita do espectro político e que vota em candidatos como Jânio Quadros e Paulo Maluf. No início dos anos 80, este tipo de voto, restrito a bairros distantes do centro da cidade, estava correlacionado negativamente com escolaridade e renda $e$ 
positivamente com não-participação na população economicamente ativa (PEA), idade e residência nos bairros intermediários das Zonas Leste e Norte. $\mathrm{Na}$ mesma linha, Novaes (1996a e 1996b) trata da geografia do voto paulistano e revela que o desempenho dos candidatos do Partido Popular Brasileiro (PPB) e do Partido da Social Democracia Brasileira (PSDB) melhorava conforme diminuía a exclusão social, ocorrendo o oposto com os do PT, do Partido Democrático Trabalhista (PDT) e Partido do Movimento Democrático Brasileiro (PMDB).

Em Figueiredo et al. (2002), os autores analisam as eleições municipais em São Paulo entre 1994 e 2000, agregando os resultados eleitorais obtidos junto ao Tribunal Regional Eleitoral (TRE-SP). O intuito principal do trabalho é verificar a existência de bases eleitorais de apoio aos partidos políticos. $\mathrm{O}$ exame do padrão de distribuição de votos na cidade revela que existe uma continuidade do apoio aos partidos em certas regiões. Eles afirmam que "PSDB, PT e PPB parecem contar com bases geográficas claramente definidas, onde o desempenho de cada um é bem acima de sua média para qualquer cargo disputado em qualquer dos pleitos realizados" (Figueiredo et al., 2002, p. 158). Tais bases geográficas são socialmente distintas, com o PSDB dominando a região centro-oeste e centro-sul, o PT a região extremo-leste, e o PPB a região leste. Além disso,

há em geral uma alta correlação entre votações em diferentes eleições e cargos em disputa quanto aos três partidos que controlam a maioria dos votos na cidade. Essa associação é mais alta no partido mais fortemente organizado, o PT, e mais baixa no mais dependente de liderança individual, o PPB. Ainda assim, parece ser possível afirmar que os partidos estruturam os votos na cidade (Figueiredo et al., 2002, p. 160).

Cabe acrescentar que a possível estruturação apontada pelos autores tem viés claramente sociológico.

Limongi (2005), por sua vez, analisa as eleições municipais em São Paulo entre 1996 e 2004 agregando os resultados do TRE-SP em 13.000 seções eleitorais, com uma média de 4.700 eleitores cada. Ele mostra a volatilidade eleitoral na cidade, que dá a vitória inicialmente aos candidatos do Partido Popular (PP), depois aos petistas e finalmente aos tucanos. Destaca 
também que o voto petista é mais estável e que as três forças na disputa tendem a se transformar em apenas duas. Outro aspecto posto em destaque é a presença de uma competição entre esquerda, centro e direita razoavelmente bem estruturada. Mais importante que isso seria a existência de redutos eleitorais paulistanos, com um claro perfil sociológico-espacial e com uma aparente polarização crescente entre uma periferia petista e um centro tucano.

Em síntese, estes estudos sobre a geografia do voto parecem-nos revelar que as hipóteses acerca de um voto sociológico, principalmente na disputa entre PSDB e PT, não podem ser descartadas de antemão.

\subsubsection{Análises eleitorais com dados de survey com amostras subnacionais}

Os primeiros trabalhos que utilizaram dados de pesquisa por amostragem de eleitores datam do início dos anos 60. Soares (1961b e 1973) analisa as eleições presidenciais de 1960, com base em dados de pesquisa com eleitores da cidade do Rio de Janeiro, e mostra que havia uma relação entre a situação socioeconômica do eleitor e a preferência pelos partidos e candidatos presidenciais na eleição daquele ano. As votações em Jânio Quadros e na UDN eram maiores entre os eleitores de níveis sociais mais elevados e menores entre os de nível mais baixo; com as votações de Lott e Adhemar e do PTB ocorria o inverso.

Em meados dos anos 70, ainda sob o bipartidarismo imposto pelos militares, várias pesquisas por amostragem foram realizadas em diversas localidades, como São Paulo, Rio de Janeiro, Porto Alegre, Belo Horizonte, Presidente Prudente, Niterói, Juiz de Fora e Caxias do Sul. As análises de dados, tanto ao nível agregado, como individual, invariavelmente apontam para uma distinção social entre os eleitores dos dois partidos (cf. Lamounier, org., 1980, Lamounier \& Cardoso, orgs., 1978, e Reis, org., 1978).

O artigo de Lamounier (1978) sobre o comportamento eleitoral em São Paulo aborda diferenças de comportamento entre os sexos, faixas etárias, status ocupacional, escolaridade e classes sociais. O autor observa que certas características demográficas e socioeconômicas, como idade, escolaridade e ocupação, estão associadas ao comportamento eleitoral, de forma que os eleitores da Aliança Renovadora Nacional (Arena) tendiam a ser mais velhos, 
mais escolarizados e detinham posições ocupacionais mais elevadas, ocorrendo o inverso com os do Movimento Democrático Brasileiro (MDB). Ele afirma que "estratos ou classes sociais são as principais bases de diferenciação das representações e interesses que se projetam no campo político sob a forma de afiliações ou identificações partidárias" (Lamounier, 1978, p. 33).

No artigo de Reis (1978a), em que são utilizados dados de um survey realizado em Belo Horizonte sobre a eleição de 1974, é analisada a relação entre a escolaridade, a renda familiar e o voto. Quanto ao primeiro desses indicadores de posição social, a escolaridade, o autor não encontrou associação com o voto: o índice de adesão ao MDB era baixo entre os menos escolarizados (menor até do que o índice dos que não souberam responder à pergunta), ganha força nas faixas intermediárias e cai na faixa superior — ou seja, segue um padrão errático. Quanto à renda, a partir do terceiro de seis níveis a relação é clara: quanto maior a renda, maior o voto na Arena; quanto menor, maior no MDB.

Isso sugere que questões de natureza econômico-social de repercussão mais imediata sobre as condições de vida da população terão tido importância especial no condicionamento da decisão dos eleitores, representando um fator capaz de dividir de maneira mais nítida as opções do que questões de natureza mais estritamente política ou de significação mais remota, cuja adequada apreciação tende a requerer certa sofisticação intelectual e a estar mais exposta à influência de variáveis como nível educacional (Reis, 1978a, p. 133).

O livro organizado por Fábio Wanderley Reis em 1978 sobre as eleições municipais de 1976 examina as relações entre indicadores socioeconômicos e voto ou preferência partidária. Naquela obra, os pesquisadores salientam a existência de padrões de comportamento eleitoral distintos nas cidades pesquisadas. De forma geral, existia a tendência de que os eleitores de status social mais elevado preferissem a Arena e os de status mais baixo dessem preferência ao MDB. Mas isso não era uma regra geral: acontecia especialmente em regiões mais industrializadas e mais densamente povoadas; fora deste contexto, o MDB era o partido minoritário, com influência restrita a certos setores mais elevados e penetração irregular entre os de condição social mais baixa (cf. Reis, org., 1978, p. 46). 
Embora nesse trabalho os autores tenham buscado uma análise mais cognitivo-psicológica, as variáveis sociais, como sexo, idade, escolaridade e renda, entre outras, em alguma medida, sempre indicam associação com o voto. Além disso, na conclusão do trabalho, Reis apresenta um modelo de centralidade política que combina duas dimensões sociológicas: a dimensão horizontal, que corresponde à oposição entre o mundo rural ou semi-rural e o mundo dos grandes centros urbanos, e a vertical, correspondente à posição socioeconômica do indivíduo. Da combinação dessas duas dimensões surgiriam contextos políticos que definiriam o comportamento político dos eleitores, desde uma situação de marginalidade subjetiva e desinformação até uma situação de atuação do modelo de consciência de classe. Nessa visão, os eleitores de baixo estrato social, tanto no meio rural, como no urbano, tendem ao conservadorismo e ao governismo, enquanto os eleitores de estratos sociais médio (especialmente no meio urbano) e alto tendem a apresentar alta estruturação ideológica (cf. Reis, org., 1978, p. 295).

A partir do final dos anos 70, ocorreram transformações profundas nas instituições políticas brasileiras, decorrentes da abertura política e da volta dos civis ao poder. Entre essas mudanças, destacam-se a reformulação do sistema partidário, o restabelecimento das eleições diretas - primeiro, em 1982, para governadores dos estados; depois, em 1985, para prefeitos das capitais; e, finalmente, em 1989, para a Presidência da República - e a Constituição de 1988. Esse conjunto de novas instituições levou a uma grande fragmentação partidária que obscureceu as manifestações das clivagens sociais em termos eleitorais ou partidários. A nova situação política, muito mais complexa que as anteriores, passou a exigir que as pesquisas sobre o comportamento eleitoral fossem representativas do conjunto do eleitorado brasileiro, que voltaria a eleger um presidente pelo voto direto depois de quase 30 anos.

\subsubsection{Análises eleitorais com dados de survey com amostras nacionais}

A realização de eleições diretas para a Presidência da República em 1989 reabriu o tema para a análise dos pesquisadores do comportamento eleitoral no Brasil. O principal corpo de pesquisa sobre o tema havia tratado até aquele momento de eleições subnacionais com dados de pesquisas por 
amostragem localizadas. A partir do retorno das eleições para presidente, foi necessário realizar pesquisas de âmbito nacional, para captar os aspectos mais importantes da nova situação política.

O artigo de Singer (1990) foi um dos primeiros que tratou dos aspectos socioeconômicos da eleição de 1989. No trabalho, o autor explora dados de pesquisa nacional realizada pelo Instituto Brasileiro de Opinião Pública e Estatística (Ibope) no final de 1989 e mostra diferenças importantes no comportamento eleitoral de acordo com as características dos eleitores. O que mais chama a atenção do autor é o fato de Fernando Collor ter sido eleito graças ao apoio que recebeu dos mais pobres, com renda de até dois salários mínimos, e dos menos escolarizados, com até o primário completo. Ele observa que "o predomínio de Collor nesses estratos não se deu no início da campanha. Houve um momento em que Collor era mais forte entre os mais ricos" (p.139). Ao longo da campanha, contudo, Collor começa a avançar sobre o eleitorado mais pobre e escolarizado, e a perder espaço entre os eleitores mais ricos e escolarizados. "Uma vez aderido a Collor, esse eleitorado resistiu a uma campanha que desgastou intensamente o candidato em outros setores da população" (Singer, 1990, p. 141). O autor também identificava, na vitória de Collor, possível retorno a um estilo populista de fazer política, à margem dos partidos, com um discurso de confronto contra as elites e com forte base de apoio entre as massas urbanas.

Um dos primeiros trabalhos de fôlego sobre o comportamento eleitoral em eleições presidenciais no Brasil foi a tese de Castro (1994). A autora argumenta que, para uma completa análise do comportamento eleitoral no Brasil, é necessário lançar mão, ao mesmo tempo, das três principais correntes por ela identificadas: os estudos sociológicos, tanto os ecológicos, como os baseados em surveys; os psicossociológicos, que levam em conta percepções, atitudes, crenças, opiniões e expectativas dos eleitores; e a perspectiva institucional, orientada por uma abordagem na linha da teoria da escolha racional. Nenhuma dessas correntes, isoladamente, teria conseguido dar conta da complexidade eleitoral brasileira, e uma teoria para explicar o comportamento eleitoral teria de considerar, simultaneamente, fatores macroestruturais e fatores de tipo micro. 
Esta abordagem é francamente influenciada pela perspectiva sociológica. A hipótese mais geral da pesquisa é que viver em contextos estruturais diferentes, em termos político-institucionais e socioeconômicos, levaria a escolhas eleitorais diferentes. Para testar essa hipótese, foram utilizados dados de uma pesquisa nacional realizada pelo Vox Populi e outra, municipal, realizada pelo Departamento de Ciência Política da Universidade Federal de Minas Gerais em Belo Horizonte.

Metodologicamente, Castro (1994) trabalha com três variáveis dependentes, todas derivadas da pergunta estimulada sobre a decisão do voto. A primeira envolve sete categorias e focaliza as intenções de voto nos principais candidatos; a segunda foi composta com três categorias, com as intenções de voto agrupadas por tendências ideológicas dos candidatos; e a terceira, com duas categorias — os eleitores que tinham candidato e os que não tinham. Como variáveis independentes, foram utilizadas a região do país e o tipo ou porte da cidade (como indicadores de dimensões macroestruturais), o sexo, a idade, a renda domiciliar e a escolaridade (como indicadores de status socioeconômico e experiências de relações sociais) e o grau de sofisticação política, a preferência partidária e as opiniões dos eleitores a respeito dos candidatos. A sofisticação política é um constructo a partir do somatório de quatro variáveis, quais sejam: o interesse por política, o envolvimento no processo eleitoral, a exposição ao programa eleitoral gratuito na televisão e o grau de informação a respeito dos candidatos.

Os dados analisados no trabalho mostram, em particular, que a intenção de voto está altamente correlacionada com a preferência partidária dos eleitores. Também evidenciam que, para explicar o comportamento eleitoral, é importante conhecer o grau de sofisticação política do eleitor. Para Castro (1994), a sofisticação política seria a variável explicativa que melhor caracterizaria o comportamento eleitoral do brasileiro. A minoria dos eleitores sofisticados vota orientada por opiniões sobre questões políticas diversas e por uma preferência partidária baseada em uma visão informada sobre os partidos e os candidatos. A maioria não sofisticada, por sua vez, é desinformada e não tem opinião sobre as grandes questões do debate político; além disso, "tende a atribuir a seus candidatos as qualidades e as opiniões que mais lhe 
agradam" (Castro, 1994, p.180). Assim, as opiniões vagas e difusas que os eleitores não sofisticados formariam dos candidatos constituiriam a orientação principal para o voto. Tais opiniões não seriam imprevisíveis ou aleatórias, mas baseadas na capacidade que cada candidato teria de transmitir uma imagem de defensor dos pobres e dos trabalhadores.

Em sua abordagem, as características socioeconômicas dos eleitores são muito importantes. A centralidade da sofisticação política é uma variável fortemente definida por aquelas características. Além disso,

fatores como escolaridade, renda familiar, idade, sexo e mesmo raça influem sobre a intenção de voto, não só porque fazem variar os graus de sofisticação política e de participação dos eleitores, como também podem estar diretamente relacionados com as escolhas eleitorais, principalmente quando os graus de sofisticação política e de participação são muito baixos (Castro, 1994, p.169).

Se levarmos em conta que, de fato, a identificação partidária, a sofisticação e a participação são baixas entre os eleitores brasileiros, o comportamento eleitoral seria, na ótica da autora, influenciado basicamente por suas características socioeconômicas. O que a autora não indica em sua análise é como as diferentes categorias das variáveis com as quais trabalha exercem impacto sobre a direção do voto. Ou seja, não se sabe, a partir do seu trabalho, se existem ou não bases sociais dos partidos ou dos candidatos.

A partir de meados dos anos 90, a preocupação com as variáveis socioeconômicas na análise do comportamento eleitoral começa a sair do foco. Trabalhos importantes que analisam eleições presidenciais, como os teses de Carreirão (2002) e Singer (2000), são indicativos dessa nova abordagem.

O trabalho de Singer (2000) sobre o comportamento do eleitor brasileiro defende a idéia de que a identificação ideológica deve ser incorporada à análise do comportamento eleitoral, por ser um dos componentes de orientação do sufrágio e uma forte variável preditiva. Não discutiremos por aqui se a ideologia tem ou não importância na disputa PSDB-PT, mas vamos destacar que o autor, em seu exame de duas eleições presidenciais, não apresenta qualquer arrazoado sobre diferenças ou semelhanças 
socioeconômicas das candidaturas. Para não dizer que as condições socioeconômicas não aparecem no trabalho de Singer, ele correlaciona a escolaridade e a renda com o voto em 1989 e 1994 e procura mostrar que estas duas variáveis têm fraca relação com o comportamento eleitoral. Ou seja, frente à ideologia, as condições socioeconômicas seriam irrelevantes para a decisão do voto.

O trabalho de Carreirão também não avalia os possíveis efeitos das características socioeconômicas na decisão do voto nas eleições presidenciais de 1989 até 1998. A tese central do trabalho é que a avaliação de desempenho dos candidatos é determinante para os resultados das eleições. Apenas se considera a escolaridade como indicador de sofisticação política. Isto é, não é utilizada para apontar variações na decisão do voto diretamente dependentes do grau de escolaridade, mas para buscar compreender o relacionamento de outras variáveis com o voto, segundo os níveis de escolaridade. Nessas condições, existiriam diferentes modelos de comportamento eleitoral, de acordo com a posição do eleitor em uma escala de sofisticação política medida pela escolaridade.

Em suma, os trabalhos que trataram de voto e condições socioeconômicas, tanto no Brasil, como no exterior, mostram que estas guardam alguma relação com o comportamento eleitoral. Desde os primórdios, com as análises de dados agregados, até os dias de hoje, com a utilização de dados de levantamentos por amostragem representativos do conjunto do eleitorado, os autores nunca deixaram de examinar algum aspecto social. $\mathrm{O}$ que diferiu foi a ênfase dada ao tema ao longo do tempo. No início, esse era o principal recorte. Pouco a pouco, foi sendo substituído por outras abordagens, ainda que seus efeitos nunca tenham sido negados.

Chama atenção, na literatura brasileira, a ausência de estudos sobre a existência de nexo causal entre condições socioeconômicas e voto, especialmente quando, nas eleições presidenciais - sempre as mais visíveis para o eleitorado - , existe claro e demorado embate entre dois partidos políticos. Ninguém ainda procurou investigar se existem características socioeconômicas significativas para a orientação do voto no PSDB ou no PT entre 1994 e 2006. Faremos isso neste capítulo: vamos nos dedicar às 
variáveis mais importantes sugeridas na literatura, quais sejam: nível socioeconômico (que está relacionado à escolaridade) e renda, sexo, religião, etnia, região do país, porte dos municípios e participação na população economicamente ativa. Antes, na próxima seção, vamos fazer uma breve apresentação do contexto socioeconômico em que ocorreram as disputas presidenciais desde 1994.

\subsection{Contexto socioeconômico das disputas presidenciais entre PSDB e PT no período de 1994 a 2006}

Não é objetivo desta seção remontar todo o cenário socioeconômico brasileiro de mais de uma década de duração. Importa apenas destacar alguns aspectos que parecem ser mais relevantes para o argumento do capítulo. $\mathrm{O}$ que buscamos aqui é testar a hipótese de que as características socioeconômicas dos eleitores afetam suas decisões eleitorais entre PSDB e PT. A seguir, portanto, traçamos um quadro sucinto das principais transformações socioeconômicas do país ao nível macro; depois, apresentamos os dados socioeconômicos utilizados nesta tese; finalmente, testamos as hipóteses sugeridas na literatura.

\subsubsection{Macrotransformações socioeconômicas}

A eleição presidencial de 1994 foi precedida de muitos anos de instabilidade. Na política, ocorreram diversos fatos inesperados logo após o retorno dos civis ao poder.

Eleito pelo colégio eleitoral, Tancredo Neves adoece e morre antes de tomar posse. O presidente eleito pelo voto direto em 1989 é impedido pelo Congresso Nacional em 1992. Na economia, os governos Sarney, Collor e Itamar editam diversos planos econômicos, os quais, via de regra, naufragam em meio a acentuadas altas inflacionárias. Na sociedade, desde os anos 80 , os movimentos sociais liderados pelas centrais sindicais e pelos trabalhadores sem terra procuram, muitas vezes pelo confronto, interferir nos assuntos de seus interesses. 
Após o impedimento do presidente Collor, o governo de Itamar Franco conseguiu formar ampla coalizão que logrou êxito em controlar a inflação a partir da edição do Plano Real. Em junho de 1994, a inflação medida pelo índice geral de preços da Fundação Getúlio Vargas (IGP-DI/FGV) foi de 46,6\%. Desde então, o pico inflacional foi observado em novembro de 2002, quando atingiu 5,8\%; em 2006, por exemplo, o índice mensal nunca foi maior que 1\%. A estabilidade econômica tornou possível melhor planejamento financeiro por parte dos eleitores, uma vez que o salário deixou de ser corroído pela inflação, o que permitiu às pessoas estenderem seus horizontes para além da semana do pagamento.

O grande legado do Plano Real foi mais do que simples estabilidade econômica. Em grande medida, o Brasil conquistou também estabilidades política e social sem precedentes. Isso não significa dizer que tenhamos ficado livres de crises políticas, econômicas ou sociais, mas que, seguramente, estamos mais resistentes a estas do que estávamos no século passado. Diversas crises políticas ocorreram durante os governos de Fernando Henrique Cardoso e Lula, todas resolvidas dentro do próprio sistema político, sem ameaças de rupturas institucionais.

Se a estabilidade que alcançamos é louvável, o país ainda é marcado por profunda desigualdade socioeconômica. O principal índice que mede a desigualdade é o de Gini. Desde 1994, caiu pouco, mas constantemente, passando de 0,60 entre 1993 e 1995 para 0,57 desde $2005,{ }^{1}$ o mais baixo patamar histórico. A taxa de pessoas pobres caiu de $42 \%$ na primeira metade dos anos 90 para em torno de 35\% após a segunda metade daquela década, chegando a 30\% em 2005. No Brasil, quase um terço da população vive com até meio salário mínimo per capita. Em termos absolutos, são cerca de 57 milhões de pessoas. Se se acrescentam a este grupo as pessoas sem rendimento, chega-se à estimativa de 63 milhões de pessoas que podem ser consideradas pobres. Dentro do país as diferenças também são acentuadas: no Nordeste, a proporção de pessoas que vivem com até um salário mínimo é de quase $51 \%$, enquanto no Sudeste não chega a $18 \%$.

\footnotetext{
${ }^{1}$ Segundo o Ipeadata, o banco de dados do Instituto de Pesquisa Econômica Aplicada (Ipea).
} 
Com a inflação estável e a desigualdade em lenta queda, o cenário macroeconômico do período deixa a desejar, quando consideramos 0 crescimento do PIB e o desemprego. O período dominado por PSDB e PT na disputa eleitoral e na Presidência da República foi o de menor crescimento econômico desde que as taxas de crescimento anual passaram a ser medidas com maior confiança. No regime democrático inaugurado em 1945 e extinto em 1964, o crescimento médio anual foi de 7,1\%; caiu para $6,2 \%$ durante a ditadura militar; para 2,8\% no período que vai do retorno dos civis à Presidência até o Plano Real; e para 2,4\% após o Plano Real. ${ }^{2}$ O PIB per capita aumentou ano a ano, pouco a pouco, passando de R\$10.840 em 1994 para $\mathrm{R} \$ 12.440 \mathrm{em} 2006 .^{3}$

Um dos aspectos mais importantes do cenário macroeconômico, por conta de seus efeitos políticos, é o desemprego. Na Região Metropolitana de São Paulo, o índice de desempregados medido pelo Departamento Intersindical de Estudos Socioeconômicos (Dieese) oscilou entre 13,6\% em janeiro de 1994 e 14,4\% no mesmo mês de 2006. Os picos de desemprego, com taxas de mais de 20\%, foram observados em 1999 e entre 2002 e $2004 .^{4}$ Os desequilíbrios regionais observados no Brasil com a grande concentração econômica pouco mudaram nesses anos. A Região Sudeste continua concentrando mais de $55 \%$ do PIB. Por um lado, a desaceleração do crescimento econômico é o ponto fraco dos governos tucano-petistas. Por outro, mesmo que lentamente, pela primeira vez o país cresce e distribui renda, e a expectativa é de aceleração do crescimento econômico.

O Brasil continua com grandes gargalos estruturais, dentre os quais um dos mais importantes é o baixo nível de escolaridade de sua população. O dado disponível mostra constante, mas lenta, melhoria nos indicadores. A taxa de analfabetismo das pessoas com 15 anos de idade ou mais passou de $16 \%$ em 1993 para 12\% em 2003; o número médio de anos que as pessoas com mais de 10 anos de idade freqüentam a escola passou de cinco para 6,4 anos,

\footnotetext{
${ }^{2}$ Segundo dados do Instituto Brasileiro de Geografia e Estatística (IBGE).

${ }^{3} \mathrm{Em} \mathrm{R} \$$ de 2006, segundo o Ipeadata.

${ }^{4}$ Segundo dados da Pesquisa de Emprego e Desemprego (PED), conduzida pela Fundação Sistema Estadual de Análise de Dados (Seade) e pelo Dieese.
} 
e a taxa de escolarização das pessoas de 7 a 24 anos aumentou em todos os grupos de idade analisados. ${ }^{5}$

De forma geral, o Brasil pós-1994 encontrou, a partir da economia, razoável estabilidade social e política. Do conjunto de dados macroeconômicos apresentados, o que se observa é que, salvo a inflação, que foi debelada e deixou de ser uma questão política importante, os demais indicadores mostram certa paralisia, sem crescimento econômico expressivo e com tímidos avanços sociais. A principal bandeira social do governo Lula, a Bolsa Família, transferência direta de recursos do Tesouro, beneficiava mais de 11 milhões de famílias de baixa renda em 2006, o que seguramente representou expressivo trunfo político.

\subsubsection{Dados socioeconômicos da tese ${ }^{6}$}

$\mathrm{Na}$ revisão da literatura que fizemos, a variável socioeconômica mais relevante para o comportamento eleitoral é a posição social do indivíduo. Essa posição foi medida das mais diversas maneiras. Mas existe, especialmente no Brasil, uma preferência por considerá-la em termos de níveis de escolaridade, ou de renda, ou de ocupação. Outras características importantes apontadas pela literatura são sexo do indivíduo, sua idade, sua etnia, sua religião, a região do país onde vive, o porte da cidade onde vive e se vive em zona rural ou urbana. Ao total, serão abordadas dez variáveis socioeconômicas.

A Tabela 1, a seguir, apresenta as variáveis independentes utilizadas para estudar o comportamento eleitoral neste capítulo. Os dados apresentados referem-se às distribuições obtidas a partir de pesquisas eleitorais representativas do conjunto do eleitorado brasileiro. Ainda que as amostras de cada uma das pesquisas tenham sido selecionadas de forma diferente, é possível assegurar que constituem o melhor retrato dos eleitores brasileiros nos momentos em que foram realizadas.

\footnotetext{
${ }^{5}$ Segundo dados do IBGE.

${ }^{6}$ A partir deste ponto, a referência aos dados da tese significa a utilização dos bancos de dados organizados pelo Datafolha (1994), indicados nas tabelas por "1994"; pelo Vox Populi (1998), indicados por "1998"; por Almeida et al. (orgs. 2002), "2002-E"; pela Ipsos Opinion (2002), "2002-I"; e pela Analítica Consultoria (2006), "2006" (ver Anexo I).
} 
Tabela 1: Características socioeconômicas dos eleitores

\begin{tabular}{|c|c|c|c|c|c|}
\hline $\begin{array}{c}\text { Características socioeconômicas } \\
\text { dos eleitores }\end{array}$ & 1994 & 1998 & 2002-E & 2002-I & 2006 \\
\hline \multicolumn{6}{|c|}{ Sexo } \\
\hline Masculino & 50 & 51 & 45 & 49 & 48 \\
\hline Feminino & 50 & 49 & 55 & 51 & 52 \\
\hline \multicolumn{6}{|c|}{ Idade } \\
\hline Mais jovens & 23 & 24 & 23 & 22 & 21 \\
\hline Intermediária 1 & 28 & 14 & 24 & 25 & 24 \\
\hline Intermediária 2 & 20 & 24 & 20 & 21 & 21 \\
\hline Intermediária 3 & 18 & 17 & 19 & 19 & 21 \\
\hline Mais velhos & 11 & 21 & 14 & 13 & 13 \\
\hline \multicolumn{6}{|c|}{$\begin{array}{l}\text { Escolaridade } \\
\end{array}$} \\
\hline Até fundamental completo & 67 & 67 & 62 & 69 & 62 \\
\hline Médio incompleto ou mais & 33 & 33 & 38 & 31 & 38 \\
\hline \multicolumn{6}{|c|}{ Renda familiar } \\
\hline Até cinco salários mínimos & 54 & 61 & 74 & 85 & 86 \\
\hline Cinco salários mínimos ou mais & 46 & 39 & 26 & 15 & 14 \\
\hline \multicolumn{6}{|c|}{ Populacão economicamente ativa (PEA) } \\
\hline PEA & $\mathrm{n} / \mathrm{d}$ & 60 & 56 & 77 & 69 \\
\hline Não-PEA & $\mathrm{n} / \mathrm{d}$ & 40 & 44 & 23 & 31 \\
\hline \multicolumn{6}{|c|}{ Etnia } \\
\hline Branco & 60 & $\mathrm{n} / \mathrm{d}$ & 48 & 56 & 40 \\
\hline Negro/Mulato & 36 & $\mathrm{n} / \mathrm{d}$ & 43 & 39 & 58 \\
\hline Outras & 4 & $\mathrm{n} / \mathrm{d}$ & 9 & 5 & 2 \\
\hline \multicolumn{6}{|c|}{ Reliqião } \\
\hline Católico & $\mathrm{n} / \mathrm{d}$ & $\mathrm{n} / \mathrm{d}$ & 70 & $\mathrm{n} / \mathrm{d}$ & 71 \\
\hline Protestante/evangélico & $\mathrm{n} / \mathrm{d}$ & $\mathrm{n} / \mathrm{d}$ & 17 & $\mathrm{n} / \mathrm{d}$ & 18 \\
\hline Outros/nenhuma & $\mathrm{n} / \mathrm{d}$ & $\mathrm{n} / \mathrm{d}$ & 13 & $\mathrm{n} / \mathrm{d}$ & 11 \\
\hline \multicolumn{6}{|c|}{ Reqião } \\
\hline Norte & $\mathrm{n} / \mathrm{d}$ & 7 & 5 & 6 & 7 \\
\hline Nordeste & $\mathrm{n} / \mathrm{d}$ & 26 & 23 & 28 & 28 \\
\hline Centro-Oeste & $\mathrm{n} / \mathrm{d}$ & 8 & 6 & 8 & 7 \\
\hline Sudeste & $\mathrm{n} / \mathrm{d}$ & 44 & 52 & 43 & 43 \\
\hline Sul & $\mathrm{n} / \mathrm{d}$ & 15 & 14 & 15 & 15 \\
\hline \multicolumn{6}{|c|}{ Porte da cidade } \\
\hline Até 100.000 habitantes & $\mathrm{n} / \mathrm{d}$ & 51 & $\mathrm{n} / \mathrm{d}$ & 49 & $\mathrm{n} / \mathrm{d}$ \\
\hline Mais de 100.000 habitantes. & $\mathrm{n} / \mathrm{d}$ & 12 & $\mathrm{n} / \mathrm{d}$ & 15 & $\mathrm{n} / \mathrm{d}$ \\
\hline Capital ou região metropolitana (RM) & $\mathrm{n} / \mathrm{d}$ & 37 & $\mathrm{n} / \mathrm{d}$ & $\mathrm{n} / \mathrm{d}$ & $\mathrm{n} / \mathrm{d}$ \\
\hline Capital & $\mathrm{n} / \mathrm{d}$ & $\mathrm{n} / \mathrm{d}$ & 29 & 23 & 24 \\
\hline Região Metropolitana & $\mathrm{n} / \mathrm{d}$ & $\mathrm{n} / \mathrm{d}$ & $\mathrm{n} / \mathrm{d}$ & 13 & 12 \\
\hline Não capital ou não rm & $\mathrm{n} / \mathrm{d}$ & $\mathrm{n} / \mathrm{d}$ & 71 & $\mathrm{n} / \mathrm{d}$ & 64 \\
\hline \multicolumn{6}{|c|}{ Área residencial } \\
\hline Rural & $\mathrm{n} / \mathrm{d}$ & 26 & $\mathrm{n} / \mathrm{d}$ & $\mathrm{n} / \mathrm{d}$ & $\mathrm{n} / \mathrm{d}$ \\
\hline Urbana & $\mathrm{n} / \mathrm{d}$ & 74 & $\mathrm{n} / \mathrm{d}$ & $\mathrm{n} / \mathrm{d}$ & $\mathrm{n} / \mathrm{d}$ \\
\hline
\end{tabular}

Legenda: $\mathrm{n} / \mathrm{d}=$ não disponível.

Fontes: ver nota de rodapé 6 , neste capítulo.

O que se observa é que apenas renda e etnia apresentam alterações significativas. A renda familiar cai consideravelmente no período. Em 1994, 53\% dos eleitores recebiam até cinco salários mínimos e $47 \%$ auferiam mais do que isso; em 1998, os dois grupos passaram para $61 \%$ e $39 \%$, respectivamente; em 2002, os porcentuais eram 69\% e 31\%; em 2006, atingiram 85\% e 15\%. A cor da pele do eleitor brasileiro também "mudou" nesses 12 anos: antes, declaravam-se brancos $60 \%$ dos entrevistados, índice que caiu para 40\% em 2006; o índice de negros e mulatos passou de $36 \%$ para $58 \%$. 
De maneira geral, é grande o índice de eleitores que possuem até o Ensino Fundamental completo, oscilando entre 67\%, em 1994 e 62\% em 2006. Isso significa que em torno de dois terços do eleitorado brasileiro tem nível de escolaridade que não vai além do Ensino Fundamental. Ou seja, a partir da leitura da tabela fica claro que o eleitorado brasileiro tornou-se mais pobre, menos branco e continuou pouco escolarizado. Isso não representa muita novidade para quem acompanha a política, mas são características importantes que exigem investigação mais sistemática para definir seus efeitos sobre a direção do voto. Algumas teorias sobre o voto dão grande peso à "qualidade do eleitor", medida das mais diferentes maneiras. Contudo, o que realmente conta no eleitorado brasileiro não é a "qualidade do eleitor", mas a grande massa de eleitores de baixo estrato social.

As outras variáveis não apresentaram mudanças significativas em suas distribuições. Resta saber se o mesmo acontece com relação aos efeitos que exercem sobre o sistema eleitoral.

\subsection{Análise dos impactos eleitorais das características socioeconômicas dos eleitores nas eleições presidenciais no Brasil de 1994 até 2006}

Nesta seção, estudam-se os impactos das condições socioeconômicas na direção do voto. Para isso, utilizamos regressões logísticas para a intenção de voto no PSDB e no PT. Os modelos de regressão são extremamente úteis para a análise multivariada, que aqui é o nosso principal objetivo. Não obstante, também realizamos análises bivariadas dos dados. Nestes casos, são usadas regressões logísticas da mesma maneira, para permitir melhor comparação entre os dados apresentados e analisados. As variáveis dependentes são "VotaPSDB" e "VotaPT", ambas com as seguintes categorias: não vota $=0 \mathrm{e}$ vota $=1$. As variáveis independentes são apresentadas e analisadas na mesma ordem da Tabela 1.

Os quadros apresentados a seguir reúnem as razões de chance (probabilidade de ocorrência do evento de interesse naquela categoria em relação à categoria de referência; as razões de chance significantes estão assinaladas por asteriscos), os erros padrão (abaixo, entre parênteses), o coeficiente de determinação $\mathrm{R}^{2}$ proposto por Nagelkerke (ver "Preâmbulo metodológico"), o 
número de casos de cada regressão, os percentuais de previsões corretas dos modelos em geral, a proporção de acerto das intenções de voto previstas, a proporção de acerto das intenções de voto observadas e as chances de ocorrência de voto na base do modelo. Com esses dados, podemos estudar os efeitos que as variáveis independentes exercem sobre as intenções de voto e examinar e comparar as qualidades dos modelos, assim como a trajetória das chances de voto em cada partido no decorrer das eleições presidenciais.

\subsubsection{Sexo}

Quanto ao sexo do eleitor nos seis pleitos que envolveram PSDB e PT na disputa pela Presidência da República, observamos que esta variável exerce pouco efeito sobre as chances de voto (ver Quadros 1 e 2, a seguir).

Quadro 1: Modelo de regressão logística para a ocorrência de voto no PSDB - Sexo $\left({ }^{a}\right)$

\begin{tabular}{|c|c|c|c|c|c|c|}
\hline & $\begin{array}{l}\text { Modelo } \\
1994\end{array}$ & $\begin{array}{l}\text { Modelo } \\
1998\end{array}$ & $\begin{array}{c}\text { Modelo } \\
2002 \\
1^{\circ} \text { turno }\end{array}$ & $\begin{array}{c}\text { Modelo } \\
2002 \\
2^{\circ} \text { turno }\end{array}$ & $\begin{array}{c}\text { Modelo } \\
2006 \\
1^{\circ} \text { turno }\end{array}$ & $\begin{array}{c}\text { Modelo } \\
2006 \\
2^{\circ} \text { turno }\end{array}$ \\
\hline \multicolumn{7}{|l|}{$\begin{array}{l}\text { VARIÁVEIS } \\
\text { SOCIOECONÔMICAS }\end{array}$} \\
\hline Sexo & $\begin{array}{c}1,177\left(^{*}\right) \\
(0,08)\end{array}$ & $\begin{array}{l}1,016 \\
(0,07)\end{array}$ & $\begin{array}{c}0,810\left(^{*}\right) \\
(0,11)\end{array}$ & $\begin{array}{c}0,777\left(^{(\star *}\right) \\
(0,10)\end{array}$ & $\begin{array}{c}0,769\left(^{*}\right) \\
(0,12)\end{array}$ & $\begin{array}{l}0,924 \\
(0,08)\end{array}$ \\
\hline $\mathrm{R}^{2}$ & 0 & 0 & 0 & 0 & 0 & 0 \\
\hline $\begin{array}{l}\mathrm{N} \\
\text { Casos previstos }\end{array}$ & 2.500 & 3.168 & 2.514 & 2.514 & 1.600 & 2.400 \\
\hline & $53 \%$ & $50 \%$ & $82 \%$ & $76 \%$ & $79 \%$ & $63 \%$ \\
\hline $\begin{array}{l}\text { previstos corretamente } \\
\text { Previsões de voto no }\end{array}$ & $0 \%$ & $0 \%$ & $0 \%$ & $0 \%$ & $0 \%$ & $0 \%$ \\
\hline PSDB corretas & $0 \%$ & $0 \%$ & $0 \%$ & $0 \%$ & $0 \%$ & $0 \%$ \\
\hline Chance na base & $45 \%$ & $50 \%$ & $20 \%$ & $26 \%$ & $23 \%$ & $38 \%$ \\
\hline
\end{tabular}

Notas: $\left({ }^{a}\right)$ A variável sexo foi operacionalizada da seguinte forma: mulher $=0$; homem $\left.=1 .{ }^{*}\right) p<0,05$. $\left({ }^{\star *}\right) p<0,01$.

Fonte: 1994: Datafolha (1994); 1998: Vox Populi (1998); 2002: Almeida et al. (2002); 2006: Analítica Consultoria (2006).

Para a ocorrência de voto no PSDB, as razões de chance indicam que o partido teve maior probabilidade de intenção de voto entre os homens em 1994 e 1998 e entre as mulheres em 2002 e em 2006, nos dois turnos. A única ocasião em que a razão de chance foi significante ao nível de $1 \%$ foi no segundo turno da eleição de 2002. Em todas os modelos, os coeficientes $\mathrm{R}^{2}$ são baixíssimos, e as 
previsões de voto corretas no PSDB com esse modelo é sempre zero. Isso significa que saber o sexo do entrevistado não explica nada do voto no PSDB.

Quadro 2: Modelo de regressão logística para a ocorrência de voto no PT - Sexo $\left({ }^{a}\right)$

\begin{tabular}{|c|c|c|c|c|c|c|}
\hline & $\begin{array}{c}\text { Modelo } \\
1994\end{array}$ & $\begin{array}{l}\text { Modelo } \\
1998\end{array}$ & $\begin{array}{c}\text { Modelo } \\
2002 \\
1^{\circ} \text { turno }\end{array}$ & $\begin{array}{c}\text { Modelo } \\
2002 \\
2^{\circ} \text { turno }\end{array}$ & $\begin{array}{c}\text { Modelo } \\
2006 \\
1^{\circ} \text { turno }\end{array}$ & $\begin{array}{c}\text { Modelo } \\
2006 \\
2^{\circ} \text { turno }\end{array}$ \\
\hline \multicolumn{7}{|l|}{$\begin{array}{l}\text { VARIÁVEIS } \\
\text { SOCIOECONÔMICAS }\end{array}$} \\
\hline $\begin{array}{l}\text { Sexo - } \\
\text { Masculino }\end{array}$ & $\begin{array}{c}1,281(*) \\
(0,10)\end{array}$ & $\begin{array}{c}1,15 \\
(0,08)\end{array}$ & $\begin{array}{c}1,183(*) \\
(0,08)\end{array}$ & $\begin{array}{l}1,159 \\
(0,08)\end{array}$ & $\begin{array}{c}1,627(* *) \\
(0,10)\end{array}$ & $\begin{array}{l}1,045 \\
(0,08)\end{array}$ \\
\hline $\mathrm{R}^{2}$ & 0 & 0 & 0 & 0 & 0,02 & 0 \\
\hline $\begin{array}{l}\mathrm{N} \\
\text { Casos previstos }\end{array}$ & 2.500 & 3.156 & 2.514 & 2.514 & 1.600 & 2.400 \\
\hline $\begin{array}{l}\text { corretamente } \\
\text { Votos no PT previstos }\end{array}$ & $79 \%$ & $76 \%$ & $57 \%$ & $54 \%$ & $56 \%$ & $56 \%$ \\
\hline $\begin{array}{l}\text { corretamente } \\
\text { Previsões de voto no }\end{array}$ & $0 \%$ & $0 \%$ & $0 \%$ & $100 \%$ & $54 \%$ & $100 \%$ \\
\hline PT corretas & $0 \%$ & $0 \%$ & $0 \%$ & $54 \%$ & $58 \%$ & $56 \%$ \\
\hline Chance na base & $19 \%$ & $23 \%$ & $41 \%$ & $53 \%$ & $46 \%$ & $55 \%$ \\
\hline
\end{tabular}

Notas: $\left({ }^{a}\right)$ A variável sexo foi operacionalizada da seguinte forma: mulher $=0$; homem $=1 .\left(^{*}\right) p<0,05$. $\left({ }^{\star *}\right) p<0,01$.

Fonte: 1994: Datafolha (1994); 1998: Vox Populi (1998); 2002: Almeida et al. (2002); 2006: Analítica Consultoria (2006).

Em todas as eleições presidenciais analisadas, o PT obteve melhor desempenho entre os homens. Contudo, essa diferença no desempenho petista foi significante ao nível de 1\% apenas no primeiro turno de 2006, quando a chance de voto no PT entre os homens foi quase $63 \%$ maior que entre as mulheres. Assim como o modelo para o PSDB, o do PT apresenta $\mathrm{R}^{2}$ e percentuais de previsões de voto corretas muito baixos. Ou seja, apesar de obter melhores chances entre os homens, a diferença é insignificante. Em linhas gerais, tanto para o PSDB, como para o PT, o sexo do eleitor informa pouco sobre seu comportamento eleitoral.

\subsubsection{Idade}

A idade do eleitor é relevante. Diversos estudos (cf. Miller \& Shanks, 1996, e Reis, org., 1978) apontaram diferenças de comportamento entre eleitores mais jovens e mais velhos: os primeiros tenderiam a um 
comportamento mais oposicionista e mais distante da política, enquanto que os últimos seriam mais governistas e mais participativos.

As razões de chance observadas entre os grupos etários são significativas ao nível de 1\% para a ocorrência de voto no PSDB nos dois turnos de 2002 e no segundo turno de 2006 (ver Quadro 3). Em 2002, as chances de voto no partido aumentavam com o aumento da idade; em 2006, o sentido se inverte, e as chances de voto aumentam à medida que diminui a idade. De qualquer forma, em todos os modelos, os $\mathrm{R}^{2}$ são muito baixos e os percentuais de acerto são quase iguais a zero, exceto no modelo para a eleição de 1998 - indicação de que a idade do eleitor é independente do comportamento, com relação ao PSDB.

Quadro 3: Modelo de regressão logística para a ocorrência de voto no PSDB - Idade $\left(^{a}\right)$

\begin{tabular}{|c|c|c|c|c|c|c|}
\hline & $\begin{array}{l}\text { Modelo } \\
1994\end{array}$ & $\begin{array}{l}\text { Modelo } \\
1998\end{array}$ & $\begin{array}{c}\text { Modelo } \\
2002 \\
1^{\circ} \text { turno } \\
\end{array}$ & $\begin{array}{c}\text { Modelo } \\
2002 \\
2^{\circ} \text { turno } \\
\end{array}$ & $\begin{array}{c}\text { Modelo } \\
2006 \\
1^{\circ} \text { turno } \\
\end{array}$ & $\begin{array}{c}\text { Modelo } \\
2006 \\
2^{\circ} \text { turno } \\
\end{array}$ \\
\hline \multicolumn{7}{|l|}{$\begin{array}{l}\text { VARIÁVEIS } \\
\text { SOCIOECONÔMICAS }\end{array}$} \\
\hline Idade & $\begin{array}{l}0,980 \\
(0,03)\end{array}$ & $\begin{array}{c}1,049\left(^{*}\right) \\
(0,02)\end{array}$ & $\begin{array}{c}1,178(* *) \\
(0,04)\end{array}$ & $\begin{array}{c}1,131(* *) \\
(0,03)\end{array}$ & $\begin{array}{l}0,939 \\
(0,05)\end{array}$ & $\begin{array}{c}0,907\left(^{* *}\right) \\
(0,03)\end{array}$ \\
\hline $\mathrm{R}^{2}$ & 0 & 0 & 0,01 & 0,01 & 0 & 0,01 \\
\hline $\begin{array}{l}\mathrm{N} \\
\text { Casos previstos }\end{array}$ & 2.498 & 3.168 & 2.514 & 2.514 & 1.600 & 2.400 \\
\hline $\begin{array}{l}\text { corretamente } \\
\text { Votos no PSDB }\end{array}$ & $53 \%$ & $52 \%$ & $82 \%$ & $76 \%$ & $79 \%$ & $63 \%$ \\
\hline $\begin{array}{l}\text { previstos corretamente } \\
\text { Previsões de voto no }\end{array}$ & $0 \%$ & $41 \%$ & $0 \%$ & $0 \%$ & $0 \%$ & $0 \%$ \\
\hline PSDB corretas & $0 \%$ & $52 \%$ & $0 \%$ & $0 \%$ & $0 \%$ & $0 \%$ \\
\hline Chance na base & $48 \%$ & $46 \%$ & $14 \%$ & $20 \%$ & $22 \%$ & $42 \%$ \\
\hline
\end{tabular}

Notas: $\left({ }^{a}\right)$ A variável idade foi operacionalizada da seguinte forma: mais jovens $=0$ até mais velhos $\left.\left.=1 .{ }^{*}\right) p<0,05 .{ }^{* *}\right) p<0,01$.

Fonte: 1994: Datafolha (1994); 1998: Vox Populi (1998); 2002: Almeida et al. (2002); 2006: Analítica Consultoria (2006).

As razões de chance entre as faixas etárias para a ocorrência de voto no PT são significantes ao nível de 1\% na eleição de 1994 e nos dois turnos de 2002, quando o partido obtinha melhores chances entre os mais jovens (ver Quadro 4). Nos dois turnos de 2006, as razões de chance foram significantes ao nível de 5\% e indicavam melhores chances do PT entre os eleitores mais velhos. Da mesma forma que o modelo do PSDB, saber a idade do eleitor importa pouco para explicar o comportamento em relação ao PT. Os $\mathrm{R}^{2}$ são 
muito baixos, e os índices de acerto não passam de zero nos modelos de 1994 até o primeiro turno de 2002 e ficam acima de 50\% nas demais eleições.

O principal aspecto que deve ser apontado com relação aos efeitos que a idade, medida em faixas etárias, exerce sobre as chances de voto é que, de fato, existe maior oposicionismo dos mais jovens e governismo dos mais velhos, tal como sugerido por Reis (org., 1978). Mas isso não exerce impacto significativo na direção do voto, porque não existe diferença entre mais jovens e mais velhos com respeito à disputa entre o PSDB e o PT.

Quadro 4: Modelo de regressão logística para a ocorrência de voto no PT - Idade $\left({ }^{a}\right)$

\begin{tabular}{|c|c|c|c|c|c|c|}
\hline & $\begin{array}{l}\text { Modelo } \\
1994\end{array}$ & $\begin{array}{l}\text { Modelo } \\
1998\end{array}$ & $\begin{array}{c}\text { Modelo } \\
2002 \\
1^{\circ} \text { turno }\end{array}$ & $\begin{array}{c}\text { Modelo } \\
2002 \\
2^{\circ} \text { turno }\end{array}$ & $\begin{array}{c}\text { Modelo } \\
2006 \\
1^{\circ} \text { turno }\end{array}$ & $\begin{array}{c}\text { Modelo } \\
2006 \\
2^{\circ} \text { turno } \\
\end{array}$ \\
\hline \multicolumn{7}{|l|}{$\begin{array}{l}\text { VARIÁVEIS } \\
\text { SOCIOECONÔMICAS }\end{array}$} \\
\hline $\begin{array}{l}\begin{array}{l}\text { Idade em } \\
\text { cinco faixas }\end{array} \\
\end{array}$ & $\begin{array}{c}0,853(* *) \\
(0,04) \\
\end{array}$ & $\begin{array}{c}0,931\left(^{*}\right) \\
(0,03)\end{array}$ & $\begin{array}{c}0,916(* \star) \\
(0,03)\end{array}$ & $\begin{array}{c}0,915\left({ }^{*}\right) \\
(0,03) \\
\end{array}$ & $\begin{array}{c}1,083(*) \\
(0,04)\end{array}$ & $\begin{array}{c}1,082\left(^{*}\right) \\
(0,03)\end{array}$ \\
\hline $\mathrm{R}^{2}$ & 0,01 & 0 & 0 & 0,01 & 0 & 0 \\
\hline $\begin{array}{l}\mathrm{N} \\
\text { Casos previstos }\end{array}$ & 2.498 & 3.168 & 2.514 & 2.514 & 1.600 & 2.400 \\
\hline $\begin{array}{l}\text { corretamente } \\
\text { Votos no PT previstos }\end{array}$ & $79 \%$ & $76 \%$ & $57 \%$ & $57 \%$ & $53 \%$ & $56 \%$ \\
\hline $\begin{array}{l}\text { corretamente } \\
\text { Previsões de voto no }\end{array}$ & $0 \%$ & $0 \%$ & $0 \%$ & $90 \%$ & $58 \%$ & $100 \%$ \\
\hline PT corretas & $0 \%$ & $0 \%$ & $0 \%$ & $57 \%$ & $54 \%$ & $56 \%$ \\
\hline Chance na base & $29 \%$ & $28 \%$ & $47 \%$ & $59 \%$ & $48 \%$ & $52 \%$ \\
\hline
\end{tabular}

Notas: $\left({ }^{a}\right)$ A variável idade foi operacionalizada da seguinte forma: mais jovens $=0$ até mais velhos $=1 .\left(^{*}\right) p<0,05 .\left(^{* *}\right) p<0,01$.

Fonte: 1994: Datafolha (1994); 1998: Vox Populi (1998); 2002: Almeida et al. (2002); 2006: Analítica Consultoria (2006).

\subsubsection{Escolaridade}

Na teoria sobre o comportamento político e eleitoral, a escolaridade dos cidadãos é encarada como variável fundamental para a compreensão da forma como eles enfrentam as questões político-eleitorais (Campbell et al., 1960, Carreirão, 2002, Castro, 1994, Converse, 1964, e Lazarsfeld, Berelson \& Gaudet, 1948, entre outros). Essa característica pessoal é a base para quase todos os indicadores de qualidade do eleitor. Porém, ainda resta saber se a escolaridade está ou não relacionada à direção do voto — ou seja, se faz 
diferença conhecer a escolaridade do eleitor para inferir a probabilidade de voto no PSDB ou no PT.

No caso do PSDB, as chances de voto no partido entre os menos escolarizados são estatisticamente as mesmas que as observadas entre os mais escolarizados nas eleições de 1994 até 2002 (ver Quadro 5). Apenas nos dois turnos de 2006 a diferença entre as chances de voto no PSDB entre esses dois grupos é estatisticamente significante ao nível de 5\%. Nesses casos, a chance de voto é mais de $60 \%$ maior entre os mais escolarizados. Contudo, essa diferença não faz com que a escolaridade seja uma boa variável para explicar o voto nos tucanos. Os $\mathrm{R}^{2}$ são muito baixos e os percentuais de acerto são nulos em todas as eleições.

Quadro 5: Modelo de regressão logística para a ocorrência de voto no PSDB - Escolaridade ( $\left.{ }^{a}\right)$

\begin{tabular}{|c|c|c|c|c|c|c|}
\hline & $\begin{array}{c}\text { Modelo } \\
1994\end{array}$ & $\begin{array}{l}\text { Modelo } \\
1998\end{array}$ & $\begin{array}{c}\text { Modelo } \\
2002 \\
1^{\circ} \text { turno } \\
\end{array}$ & $\begin{array}{c}\text { Modelo } \\
2002 \\
2^{\circ} \text { turno }\end{array}$ & $\begin{array}{c}\text { Modelo } \\
2006 \\
1^{\circ} \text { turno }\end{array}$ & $\begin{array}{c}\text { Modelo } \\
2006 \\
2^{\circ} \text { turno }\end{array}$ \\
\hline \multicolumn{7}{|l|}{$\begin{array}{l}\text { VARIÁVEIS } \\
\text { SOCIOECONÔMICAS }\end{array}$} \\
\hline Escolaridade & $\begin{array}{l}0,908 \\
(0,09)\end{array}$ & $\begin{array}{c}0,9 \\
(0,08)\end{array}$ & $\begin{array}{l}1,01 \\
(0,1)\end{array}$ & $\begin{array}{l}1,132 \\
(0,09)\end{array}$ & $\begin{array}{c}1,618(* *) \\
(0,11)\end{array}$ & $\begin{array}{c}1,653(* *) \\
(0,09)\end{array}$ \\
\hline $\mathrm{R}^{2}$ & 0 & 0 & 0 & 0 & 0,02 & 0,02 \\
\hline $\mathrm{N}$ & 2.499 & 3.156 & 2.514 & 2.514 & 1.600 & 2.400 \\
\hline Casos previstos & & cono & 010 & 750 & con & 0200 \\
\hline $\begin{array}{l}\text { corretamente } \\
\text { Votos no PSDB }\end{array}$ & $53 \%$ & $60 \%$ & $81 \%$ & $15 \%$ & $09 \%$ & $03 \%$ \\
\hline $\begin{array}{l}\text { previstos corretamente } \\
\text { Previsões de voto no }\end{array}$ & $0 \%$ & $0 \%$ & $0 \%$ & $0 \%$ & $0 \%$ & $0 \%$ \\
\hline PSDB corretas & $0 \%$ & $0 \%$ & $0 \%$ & $0 \%$ & $0 \%$ & $0 \%$ \\
\hline Chance na base & $48 \%$ & $41 \%$ & $19 \%$ & $24 \%$ & $27 \%$ & $33 \%$ \\
\hline
\end{tabular}

Notas: $\left({ }^{a}\right)$ A variável escolaridade foi operacionalizada da seguinte forma: menos escolarizados, até fundamental completo $=0$ e mais escolarizados, a partir de médio incompleto $=1 .\left(^{*}\right) p<0,05$. $(* \star) p<0,01$.

Fonte: 1994: Datafolha (1994); 1998: Vox Populi (1998); 2002: Almeida et al. (2002); 2006: Analítica Consultoria (2006).

Os modelos de regressão logística para as chances de voto no PT com a covariável escolaridade indicam substancial mudança na base de apoio do partido (ver Quadro 6, a seguir). Conhecer a escolaridade do eleitor é significante para as chances de voto no PT em quatro dos seis modelos apresentados abaixo. Apenas nos dois turnos de 2002 as razões de chance não são significantes. Considerando-se as demais eleições, todas são significantes 
ao nível de 1\%. Entretanto, as chances de voto no partido entre os mais escolarizados é 58\% maior em 1994 e 35\% maior em 1998. Em 2006, a situação inverte-se: as chances de voto no partido são menores entre os mais escolarizados, cerca de 50\% menor nos dois turnos. Em geral, a qualidade dos modelos é ruim. Os $\mathrm{R}^{2}$ são baixos e os índices de acerto são iguais a zero nos três primeiros modelos, mas conseguem prever corretamente mais de 50\% das ocorrências de voto no partido a partir do segundo turno de 2002.

Quadro 6: Modelo de regressão logística para a ocorrência de voto no PT - Escolaridade $\left({ }^{\mathrm{a}}\right)$

\begin{tabular}{|c|c|c|c|c|c|c|}
\hline & $\begin{array}{c}\text { Modelo } \\
1994\end{array}$ & $\begin{array}{l}\text { Modelo } \\
1998\end{array}$ & $\begin{array}{c}\text { Modelo } \\
2002 \\
1^{\circ} \text { turno }\end{array}$ & $\begin{array}{c}\text { Modelo } \\
2002 \\
2^{\circ} \text { turno }\end{array}$ & $\begin{array}{c}\text { Modelo } \\
2006 \\
1^{\circ} \text { turno }\end{array}$ & $\begin{array}{l}\text { Modelo } \\
2006 \\
2^{\circ} \text { turno }\end{array}$ \\
\hline \multicolumn{7}{|l|}{$\begin{array}{l}\text { VARIÁVEIS } \\
\text { SOCIOECONÔMICAS }\end{array}$} \\
\hline Escolaridade & $\begin{array}{c}1,577(* *) \\
(0,1)\end{array}$ & $\begin{array}{c}1,349\left(^{* *}\right) \\
(0,09)\end{array}$ & $\begin{array}{l}1,05 \\
(0,08)\end{array}$ & $\begin{array}{c}1,16 \\
(0,08)\end{array}$ & $\begin{array}{c}0,491(* *) \\
(0,1)\end{array}$ & $\begin{array}{c}0,589(* *) \\
(0,09)\end{array}$ \\
\hline $\mathrm{R}^{2}$ & 0,01 & 0,01 & 0 & 0 & 0,04 & 0,02 \\
\hline $\begin{array}{l}\mathrm{N} \\
\text { Casos previstos }\end{array}$ & 2.500 & 3.156 & 2.514 & 2.514 & 1.600 & 2.400 \\
\hline $\begin{array}{l}\text { corretamente } \\
\text { Votos no PT previstos }\end{array}$ & $79 \%$ & $76 \%$ & $57 \%$ & $54 \%$ & $59 \%$ & $58 \%$ \\
\hline $\begin{array}{l}\text { Corretamente } \\
\text { Previsões de voto no }\end{array}$ & $0 \%$ & $0 \%$ & $0 \%$ & $100 \%$ & $70 \%$ & $67 \%$ \\
\hline PT corretas & $0 \%$ & $0 \%$ & $0 \%$ & $54 \%$ & $58 \%$ & $61 \%$ \\
\hline Chance na base & $19 \%$ & $22 \%$ & $42 \%$ & $53 \%$ & $58 \%$ & $61 \%$ \\
\hline
\end{tabular}

Notas: $\left(^{a}\right)$ A variável escolaridade foi operacionalizada da seguinte forma: menos escolarizados, até fundamental completo $=0$ e mais escolarizados, a partir de médio incompleto $=1 .\left(^{*}\right) p<0,05$. $(* \star) p<0,01$.

Fonte: 1994: Datafolha (1994); 1998: Vox Populi (1998); 2002: Almeida et al. (2002); 2006: Analítica Consultoria (2006).

Esses dados mostram que o conhecimento da escolaridade do eleitor é mais importante para se explicar a ocorrência de voto no governo ou na oposição, uma vez que foi quase uma constante o fato de as chances de voto no partido do governo serem maiores entre os menos escolarizados e no partido de oposição serem maiores entre os mais escolarizados, exceto pelos dois turnos de 2002. Contudo, para o que nos interessa neste trabalho, saber a escolaridade informa muito pouco sobre a direção do voto entre PSDB e PT. Por outro lado, aparentemente a eleição de 2006 mostra certa polarização entre os menos escolarizados, que apóiam o governo petista, e os mais escolarizados, que aderem à oposição tucana. 


\subsubsection{Renda}

Outra variável importante para a análise do comportamento político é a renda familiar. É indicadora - como a escolaridade - da posição social do indivíduo e da "qualidade do eleitor", face ao pressuposto de que patamares superiores de renda ampliam as possibilidades de acesso à informação. No caso brasileiro, a renda familiar exerce efeitos importantes com relação à direção do voto.

Quadro 7: Modelo de regressão logística para a ocorrência de voto no PSDB - Renda familiar $\left({ }^{\mathrm{a}}\right)$

\begin{tabular}{|c|c|c|c|c|c|c|}
\hline & $\begin{array}{l}\text { Modelo } \\
1994\end{array}$ & $\begin{array}{l}\text { Modelo } \\
1998\end{array}$ & $\begin{array}{c}\text { Modelo } \\
2002 \\
1^{\circ} \text { turno }\end{array}$ & $\begin{array}{l}\text { Modelo } \\
2002 \\
2^{\circ} \text { turno }\end{array}$ & $\begin{array}{c}\text { Modelo } \\
2006 \\
1^{\circ} \text { turno }\end{array}$ & $\begin{array}{l}\text { Modelo } \\
2006 \\
2^{\circ} \text { turno }\end{array}$ \\
\hline \multicolumn{7}{|l|}{$\begin{array}{l}\text { VARIÁVEIS } \\
\text { SOCIOECONÔMICAS }\end{array}$} \\
\hline $\begin{array}{l}\text { Renda } \\
\text { familiar }\end{array}$ & $\begin{array}{l}1,157 \\
(0,09) \\
\end{array}$ & $\begin{array}{l}0,928 \\
(0,08)\end{array}$ & $\begin{array}{c}1,376\left(^{* \star}\right) \\
(0,11) \\
\end{array}$ & $\begin{array}{c}1,652(* *) \\
(0,1)\end{array}$ & $\begin{array}{c}1,486\left(^{* *}\right) \\
(0,17)\end{array}$ & $\begin{array}{c}1,729(* *) \\
(0,13) \\
\end{array}$ \\
\hline $\mathrm{R}^{2}$ & 0 & 0 & 0,01 & 0,02 & 0,01 & 0,01 \\
\hline $\mathrm{N}$ & 2.147 & 3.156 & 2.514 & 2.514 & 1.453 & 2.203 \\
\hline $\begin{array}{l}\text { Casos previstos } \\
\text { corretamente } \\
\text { Votos no PSDB }\end{array}$ & $53 \%$ & $60 \%$ & $81 \%$ & $75 \%$ & $80 \%$ & $63 \%$ \\
\hline $\begin{array}{l}\text { previstos corretamente } \\
\text { Previsões de voto no }\end{array}$ & $0 \%$ & $0 \%$ & $0 \%$ & $0 \%$ & $0 \%$ & $0 \%$ \\
\hline PSDB corretas & $0 \%$ & $0 \%$ & $0 \%$ & $0 \%$ & $0 \%$ & $0 \%$ \\
\hline Chance na base & $45 \%$ & $40 \%$ & $17 \%$ & $22 \%$ & $19 \%$ & $35 \%$ \\
\hline
\end{tabular}

Notas: $\left({ }^{a}\right)$ A variável renda familiar foi operacionalizada da seguinte forma: renda até cinco salários mínimos $=0$ e renda maior que cinco salários mínimos $\left.=1 .{ }^{*}\right) p<0,05 .\left({ }^{\star *}\right) p<0,01$. Fonte: 1994: Datafolha (1994); 1998: Vox Populi (1998); 2002: Almeida et al. (2002); 2006: Analítica Consultoria (2006).

Nos modelos do PSDB, a renda da família do eleitor faz diferença estatisticamente significante para as chances de voto no partido nos dois turnos das eleições de 2002 e 2006 (ver Quadro 7, acima). Nessas ocasiões, o fato de o eleitor ter renda familiar a partir de cinco salários mínimos significava probabilidade maior de voto nos tucanos. Os índices variam entre 38\% a mais no primeiro turno de 2002 até 73\% a mais no segundo turno de 2006. Apesar da diferença entre os dois grupos, até cinco salários mínimos e cinco salários mínimos ou mais, o ajuste do modelo é ruim. Os $\mathrm{R}^{2}$ são muito baixos e os percentuais de acerto são nulos.

Para os modelos do PT, as razões de chance entre os dois grupos de renda são significantes somente nos dois turnos de 2006 (ver Quadro 8). Nessas eleições, as chances de voto no PT entre os eleitores com renda 
familiar igual ou superior a cinco salários mínimos eram quase a metade das observadas entre os de menor renda familiar. Em todas as demais eleições, a renda não influía significativamente nas chances de voto do partido. Assim como nos modelos anteriores, os $\mathrm{R}^{2}$ são muito baixos e as previsões de voto no PT corretas são iguais a zero até o primeiro turno de 2002 e superam os $50 \%$ nas eleições subseqüentes.

Quadro 8: Modelo de regressão logística para a ocorrência de voto no PT - Renda familiar $\left(^{\mathrm{a}}\right)$

\begin{tabular}{|c|c|c|c|c|c|c|}
\hline & $\begin{array}{c}\text { Modelo } \\
1994\end{array}$ & $\begin{array}{l}\text { Modelo } \\
1998\end{array}$ & $\begin{array}{c}\text { Modelo } \\
2002 \\
1^{\circ} \text { turno } \\
\end{array}$ & $\begin{array}{c}\text { Modelo } \\
2002 \\
2^{\circ} \text { turno } \\
\end{array}$ & $\begin{array}{c}\text { Modelo } \\
2006 \\
1^{\circ} \text { turno }\end{array}$ & $\begin{array}{c}\text { Modelo } \\
2006 \\
2^{\circ} \text { turno } \\
\end{array}$ \\
\hline \multicolumn{7}{|l|}{$\begin{array}{l}\text { VARIÁVEIS } \\
\text { SOCIOECONÔMICAS }\end{array}$} \\
\hline $\begin{array}{l}\text { Renda } \\
\text { familiar }\end{array}$ & $\begin{array}{c}1,108 \\
(0,1) \\
\end{array}$ & $\begin{array}{l}1,078 \\
(0,09) \\
\end{array}$ & $\begin{array}{l}0,963 \\
(0,09) \\
\end{array}$ & $\begin{array}{l}0,968 \\
(0,09)\end{array}$ & $\begin{array}{c}0,555\left(^{* \star}\right) \\
(0,15) \\
\end{array}$ & $\begin{array}{c}0,526(* *) \\
(0,13) \\
\end{array}$ \\
\hline $\mathrm{R}^{2}$ & 0,001 & 0 & 0 & 0 & 0,015 & 0,016 \\
\hline $\begin{array}{l}\mathrm{N} \\
\text { Casos previstos }\end{array}$ & 2.147 & 3.156 & 2.514 & 2.514 & 1.453 & 2.203 \\
\hline $\begin{array}{l}\text { corretamente } \\
\text { Votos no PT previstos }\end{array}$ & $78 \%$ & $76 \%$ & $57 \%$ & $54 \%$ & $55 \%$ & $58 \%$ \\
\hline $\begin{array}{l}\text { corretamente } \\
\text { Previsões de voto no }\end{array}$ & $0 \%$ & $0 \%$ & $0 \%$ & $100 \%$ & $88 \%$ & $90 \%$ \\
\hline PT corretas & $0 \%$ & $0 \%$ & $0 \%$ & $54 \%$ & $54 \%$ & $58 \%$ \\
\hline Chance na base & $21 \%$ & $23 \%$ & $43 \%$ & $55 \%$ & $54 \%$ & $58 \%$ \\
\hline
\end{tabular}

Notas: $\left(^{a}\right)$ A variável renda familiar foi operacionalizada da seguinte forma: renda até cinco salários mínimos $=0$ e renda maior que cinco salários mínimos $\left.=1 .{ }^{*}\right) p<0,05 .\left({ }^{* *}\right) p<0,01$. Fonte: 1994: Datafolha (1994); 1998: Vox Populi (1998); 2002: Almeida et al. (2002); 2006: Analítica Consultoria (2006).

Examinando-se os modelos tucanos e petistas relativos à variável renda, reforçamos a observação feita quanto à escolaridade, no que diz respeito a uma possível polarização entre PSDB e PT entre os eleitores de posição social mais baixa e mais alta em 2006.

\subsubsection{População economicamente ativa}

A ocupação sempre foi tida como característica importante para a definição do voto, com os trabalhadores de diferentes estratos apoiando candidatos diversos. Os dados de que dispomos não permitem ordenar as ocupações, de forma a identificá-las, tal como faz Soares (1973). Foi possível apenas separar os eleitores entre os que pertencem ou não à população economicamente ativa 
(PEA). No caso do PSDB, essa variável não exerce qualquer influência sobre o comportamento em relação ao partido (ver Quadro 9). As razões de chance não são significantes e indicam, exceto no segundo turno de 2006, chances menores para o partido entre eleitores que trabalham. Todos os modelos têm $\mathrm{R}^{2}$ iguais a zero, assim como os índices de previsão de voto.

Quadro 9: Modelo de regressão logística para a ocorrência de voto no PSDB - PEA $\left(^{a}\right)$

\begin{tabular}{lccccc}
\hline \hline & $\begin{array}{c}\text { Modelo } \\
\mathbf{1 9 9 8}\end{array}$ & $\begin{array}{c}\text { Modelo } \\
\mathbf{2 0 0 2} \\
\mathbf{1}^{\mathbf{0}} \text { turno }\end{array}$ & $\begin{array}{c}\text { Modelo } \\
\mathbf{2 0 0 2} \\
\mathbf{2}^{\mathbf{0}} \text { turno }\end{array}$ & $\begin{array}{c}\text { Modelo } \\
\mathbf{2 0 0 6} \\
\mathbf{1}^{\mathbf{0}} \text { turno }\end{array}$ & $\begin{array}{c}\text { Modelo } \\
\mathbf{2 0 0 6} \\
\mathbf{2}^{\mathbf{0}} \text { turno }\end{array}$ \\
\hline \hline VARIÁVEIS SOCIOECONÔMICAS & & & & & \\
\multicolumn{1}{c}{ PEA } & 0,946 & 0,919 & 0,946 & 0,956 & 1,137 \\
& $(0,1)$ & $(0,1)$ & $(0,1)$ & $(0,1)$ & $(0,1)$ \\
\hline $\mathrm{R}^{2}$ & 0 & 0 & 0 & 0 & 0 \\
$\mathrm{~N}$ & 3.195 & 2.514 & 2.514 & 1.600 & 2.400 \\
Casos previstos corretamente & $56 \%$ & $81 \%$ & $75 \%$ & $79 \%$ & $63 \%$ \\
Votos no PT previstos corretamente & $0 \%$ & $0 \%$ & $0 \%$ & $0 \%$ & $0 \%$ \\
Previsões de voto no PT corretas & $0 \%$ & $0 \%$ & $0 \%$ & $0 \%$ & $0 \%$ \\
Chance na base & $21 \%$ & $20 \%$ & $25 \%$ & $21 \%$ & $35 \%$ \\
\hline \hline
\end{tabular}

Notas: $\left({ }^{a}\right)$ A variável PEA foi operacionalizada da seguinte forma: não-PEA $=0$; PEA $=1 .\left(^{*}\right) p<0,05$. $\left({ }^{\star *}\right) p<0,01$.

Fonte: 1998: Vox Populi (1998); 2002: Almeida et al. (2002); 2006: Analítica Consultoria (2006).

Quadro 10: Modelo de regressão logística para a ocorrência de voto no PT - PEA $\left({ }^{a}\right)$

\begin{tabular}{|c|c|c|c|c|c|}
\hline & $\begin{array}{l}\text { Modelo } \\
1998\end{array}$ & $\begin{array}{c}\text { Modelo } \\
2002 \\
1^{\circ} \text { turno } \\
\end{array}$ & $\begin{array}{c}\text { Modelo } \\
2002 \\
2^{\circ} \text { turno } \\
\end{array}$ & $\begin{array}{c}\text { Modelo } \\
2006 \\
1^{\circ} \text { turno } \\
\end{array}$ & $\begin{array}{c}\text { Modelo } \\
2006 \\
2^{\circ} \text { turno } \\
\end{array}$ \\
\hline \multicolumn{6}{|l|}{$\begin{array}{l}\text { VARIÁVEIS } \\
\text { SOCIOECONÔMICAS }\end{array}$} \\
\hline PEA & $\begin{array}{c}1,248\left(^{*}\right) \\
(0,1) \\
\end{array}$ & $\begin{array}{c}1,398(* *) \\
(0,1)\end{array}$ & $\begin{array}{c}1,454(* *) \\
(0,1)\end{array}$ & $\begin{array}{c}1,004 \\
(0,1) \\
\end{array}$ & $\begin{array}{c}0,943 \\
(0,1)\end{array}$ \\
\hline $\mathrm{R}^{2}$ & 0,03 & 0,01 & 0,01 & 0 & 0 \\
\hline $\mathrm{N}$ & 3.195 & 2.514 & 2.514 & 1.600 & 2.400 \\
\hline $\begin{array}{l}\text { Casos previstos corretamente } \\
\text { Votos no PT previstos }\end{array}$ & $77 \%$ & $57 \%$ & $56 \%$ & $51 \%$ & $56 \%$ \\
\hline $\begin{array}{l}\text { corretamente } \\
\text { Previsões de voto no PT }\end{array}$ & $0 \%$ & $0 \%$ & $72 \%$ & $100 \%$ & $100 \%$ \\
\hline corretas & $0 \%$ & $0 \%$ & $57 \%$ & $51 \%$ & $56 \%$ \\
\hline Chance na base & $21 \%$ & $37 \%$ & $48 \%$ & $51 \%$ & $57 \%$ \\
\hline
\end{tabular}

Notas: $\left({ }^{a}\right)$ A variável PEA foi operacionalizada da seguinte forma: não-PEA $=0$; PEA $=1 .\left(^{\star}\right) p<0,05$. $\left({ }^{\star *}\right) p<0,01$.

Fonte: 1998: Vox Populi (1998); 2002: Almeida et al. (2002); 2006: Analítica Consultoria (2006).

Nos modelos para a ocorrência de voto no PT, observamos entre 1998 e 2002 maiores chances de voto no partido entre os eleitores que compõem a 
PEA (ver Quadro 10). No segundo turno de 2002, a razão de chance indica probabilidade $45 \%$ maior em comparação com os eleitores fora da PEA. A variável deixa de ter significância em 2006 e passa a indicar, no segundo turno, chance maior de voto no PT entre os eleitores fora da PEA. Exceto pela eleição de 2002, fazer parte ou não da PEA não nos informa nada sobre o voto no PSDB ou no PT.

\subsubsection{Etnia}

As razões de chance de todos os modelos para a ocorrência de voto no PSDB indicam probabilidades maiores de voto no partido entre os eleitores brancos, quando comparados aos não-brancos (ver Quadro 11). Essas diferenças são significativas ao nível de 1\% nos dois turnos de 2002 e de 2006. Na última eleição, a chance de voto no PSDB entre os brancos foi mais de $90 \%$ superior que a entre os não-brancos. Os modelos possuem $\mathrm{R}^{2}$ muito baixos e não conseguem prever corretamente os votos no partido.

Quadro 11: Modelo de regressão logística para a ocorrência de voto no PSDB - Etnia $\left({ }^{a}\right)$

\begin{tabular}{|c|c|c|c|c|c|}
\hline & $\begin{array}{c}\text { Modelo } \\
1994\end{array}$ & $\begin{array}{c}\text { Modelo } \\
2002 \\
1^{\circ} \text { turno } \\
\end{array}$ & $\begin{array}{c}\text { Modelo } \\
2002 \\
2^{\circ} \text { turno } \\
\end{array}$ & $\begin{array}{c}\text { Modelo } \\
2006 \\
1^{\circ} \text { turno }\end{array}$ & $\begin{array}{c}\text { Modelo } \\
2006 \\
2^{\circ} \text { turno }\end{array}$ \\
\hline \multicolumn{6}{|l|}{ VARIÁVEIS SOCIOECONÔMICAS } \\
\hline Branco & $\begin{array}{l}1,034 \\
(0,08)\end{array}$ & $\begin{array}{c}1,447\left({ }^{* *}\right) \\
(0,1)\end{array}$ & $\begin{array}{c}1,217\left(^{*}\right) \\
(0,09)\end{array}$ & $\begin{array}{l}\left.1,9{ }^{* *}\right) \\
(0,13)\end{array}$ & $\begin{array}{c}\left.1,949{ }^{* *}\right) \\
(0,11)\end{array}$ \\
\hline $\mathrm{R}^{2}$ & 0 & 0,01 & 0 & 0,03 & 0,03 \\
\hline $\mathrm{N}$ & 2.500 & 2.514 & 2.514 & 1.600 & 1.600 \\
\hline Casos previstos corretamente & $53 \%$ & $81 \%$ & $75 \%$ & $79 \%$ & $69 \%$ \\
\hline Votos no PT previstos corretamente & $0 \%$ & $0 \%$ & $0 \%$ & $0 \%$ & $0 \%$ \\
\hline Previsões de voto no PT corretas & $0 \%$ & $0 \%$ & $0 \%$ & $0 \%$ & $0 \%$ \\
\hline Chance na base & $46 \%$ & $16 \%$ & $23 \%$ & $16 \%$ & $25 \%$ \\
\hline
\end{tabular}

Notas: $\left(^{a}\right)$ A variável etnia foi operacionalizada da seguinte forma: não branco = 0 e branco $=1$. $\left(^{*}\right) p<0,05 .\left(^{\star *}\right) p<0,01$.

Fonte: 1994: Datafolha (1994); 2002: Almeida et al. (2002); 2006: Analítica Consultoria (2006).

Quanto ao PT, as chances de voto são sempre menores entre os brancos quando comparados aos não-brancos (ver Quadro 12, a seguir). Essas diferenças são significativas ao nível de 1\% apenas nos dois turnos de 2006, quando a probabilidade de um branco votar no PT foi menos da metade da observada entre os não-brancos. Assim como os modelos do PSDB, os do 
PT apresentam $\mathrm{R}^{2}$ muito baixos, mas conseguem prever em torno de $60 \%$ do comportamento em relação ao partido nos dois turnos de 2006.

Quadro 12: Modelo de regressão logística para a ocorrência de voto no PT - Etnia $\left({ }^{\text {a }}\right)$

\begin{tabular}{|c|c|c|c|c|c|}
\hline & $\begin{array}{l}\text { Modelo } \\
1994\end{array}$ & $\begin{array}{c}\text { Modelo } \\
2002 \\
1^{\circ} \text { turno } \\
\end{array}$ & $\begin{array}{c}\text { Modelo } \\
2002 \\
2^{\circ} \text { turno } \\
\end{array}$ & $\begin{array}{c}\text { Modelo } \\
2006 \\
1^{\circ} \text { turno } \\
\end{array}$ & $\begin{array}{c}\text { Modelo } \\
2006 \\
2^{\circ} \text { turno } \\
\end{array}$ \\
\hline \multicolumn{6}{|l|}{$\begin{array}{l}\text { VARIÁVEIS } \\
\text { SOCIOECONÔMICAS }\end{array}$} \\
\hline Branco & $\begin{array}{c}0,939 \\
(0,1)\end{array}$ & $\begin{array}{l}0,934 \\
(0,08)\end{array}$ & $\begin{array}{l}0,912 \\
(0,08)\end{array}$ & $\begin{array}{c}0,493(* *) \\
(0,1)\end{array}$ & $\begin{array}{c}0,495(* *) \\
(0,1)\end{array}$ \\
\hline $\mathrm{R}^{2}$ & 0 & 0 & 0 & 0,04 & 0,04 \\
\hline $\mathrm{N}$ & 2.500 & 2.514 & 2.514 & 1.600 & 1.600 \\
\hline $\begin{array}{l}\text { Casos previstos corretamente } \\
\text { Votos no PT previstos }\end{array}$ & $79 \%$ & $57 \%$ & $54 \%$ & $59 \%$ & $60 \%$ \\
\hline $\begin{array}{l}\text { corretamente } \\
\text { Previsões de voto no PT }\end{array}$ & $0 \%$ & $0 \%$ & $100 \%$ & $68 \%$ & $67 \%$ \\
\hline corretas & $0 \%$ & $0 \%$ & $54 \%$ & $58 \%$ & $63 \%$ \\
\hline Chance na base & $22 \%$ & $44 \%$ & $55 \%$ & $58 \%$ & $63 \%$ \\
\hline
\end{tabular}

Notas: $\left({ }^{a}\right)$ A variável etnia foi operacionalizada da seguinte forma: não branco $=0$ e branco $=1$. $\left.\left.{ }^{*}\right) p<0,05 .{ }^{* *}\right) p<0,01$.

Fonte: 1994: Datafolha (1994); 2002: Almeida et al. (2002); 2006: Analítica Consultoria (2006).

Considerada isoladamente, a cor da pele do eleitor parece ser uma variável importante para a definição do voto nos dois partidos, uma vez que, em todas as eleições estudadas, o PSDB obteve melhor desempenho entre os brancos e o PT entre os não brancos.

\subsubsection{Religião}

A religião é variável importante para a análise do comportamento eleitoral. Tanto nos EUA, como no Brasil, existem conexões entre religião e voto nos partidos. Lá, os católicos sempre foram majoritariamente democratas, enquanto que, aqui, grupos da Igreja Católica, como as comunidades eclesiais de base e as pastorais da terra e dos trabalhadores, estiveram envolvidos na criação do PT. Outro aspecto similar é a mobilidade religiosa, que faz aumentar o número de evangélicos, os quais buscam um posicionamento político claro. Portanto, espera-se que religião e comportamento eleitoral estejam associados em alguma medida, especialmente com o PT. 
Observando inicialmente os modelos do PSDB, temos que as razões de chance entre católicos e não católicos foram significantes ao nível de 1\% no primeiro turno de 2002 e no segundo turno de 2006, ambos os casos indicando maior chance de voto entre os católicos (ver Quadro 13). No segundo turno de 2002 e no primeiro de 2006, a religião foi independente do voto no PSDB. Assim como todos os modelos anteriores, os $\mathrm{R}^{2}$ são muito baixos e as previsões de voto são nulas.

\begin{tabular}{|c|c|c|c|c|}
\hline & $\begin{array}{c}\text { Modelo } \\
2002 \\
1^{\circ} \text { turno }\end{array}$ & $\begin{array}{c}\text { Modelo } \\
2002 \\
2^{\circ} \text { turno }\end{array}$ & $\begin{array}{l}\text { Modelo } \\
2006 \\
1^{\circ} \text { turno }\end{array}$ & $\begin{array}{c}\text { Modelo } \\
2006 \\
2^{\circ} \text { turno }\end{array}$ \\
\hline \multicolumn{5}{|l|}{ VARIÁVEIS SOCIOECONÔMICAS } \\
\hline Católico & $\begin{array}{c}1,657\left(^{\star *}\right) \\
(0,12)\end{array}$ & $\begin{array}{c}0,998 \\
(0,1)\end{array}$ & $\begin{array}{l}0,977 \\
(0,13)\end{array}$ & $\begin{array}{c}1,296(* \star) \\
(0,1)\end{array}$ \\
\hline $\mathrm{R}^{2}$ & 0,01 & 0 & 0 & 0 \\
\hline $\mathrm{N}$ & 2.514 & 2.514 & 1.600 & 2.400 \\
\hline Casos previstos corretamente & $81 \%$ & $75 \%$ & $79 \%$ & $63 \%$ \\
\hline Votos no PSDB previstos corretamente & $0 \%$ & $0 \%$ & $0 \%$ & $0 \%$ \\
\hline Previsões de voto no PSDB corretas & $0 \%$ & $0 \%$ & $0 \%$ & $0 \%$ \\
\hline Chance na base & $14 \%$ & $25 \%$ & $20 \%$ & $33 \%$ \\
\hline
\end{tabular}

Notas: $\left({ }^{\mathrm{a}}\right)$ A variável religião foi operacionalizada da seguinte forma: não católico $=0$; católico $=1$. $\left.{ }^{*}\right) p<0,05 .\left(^{* *}\right) p<0,01$.

Fonte: 2002: Almeida et al. (2002); 2006: Analítica Consultoria (2006).

Para os modelos do PT, a hipótese se confirma (ver Quadro 14, a seguir). De fato, o partido apresenta maiores chances de voto entre os católicos nas duas eleições analisadas, exceto no segundo turno de 2006, quando a razão de chance indica menor probabilidade de voto no PT entre os católicos, mas a diferença não é significante. Todos os $\mathrm{R}^{2}$ são muito baixos; entretanto, os modelos do segundo turno de 2002 e do primeiro turno de 2006 apresentam índices de previsões corretas de voto no partido acima de 50\%.

Comparando os dois modelos, o que chama a atenção são as maiores chances de voto no PSDB e PT entre os católicos no primeiro turno de 2002 , quando o candidato pelo PSB, Anthony Garotinho, apresentava-se como o candidato dos evangélicos, que são maioria entre os não católicos. A presença de Garotinho introduziu episódica polarização religiosa, que deixou PSDB e PT no mesmo campo de disputa. 
Quadro 14: Modelo de regressão logística para a ocorrência de voto no PT - Religião ( ${ }^{\mathrm{a}}$ )

\begin{tabular}{|c|c|c|c|c|}
\hline & $\begin{array}{c}\text { Modelo } \\
2002 \\
1^{\circ} \text { turno } \\
\end{array}$ & $\begin{array}{c}\text { Modelo } \\
2002 \\
2^{\circ} \text { turno } \\
\end{array}$ & $\begin{array}{c}\text { Modelo } \\
2006 \\
1^{\circ} \text { turno } \\
\end{array}$ & $\begin{array}{c}\text { Modelo } \\
2006 \\
2^{\circ} \text { turno } \\
\end{array}$ \\
\hline \multicolumn{5}{|l|}{ VARIÁVEIS SOCIOECONÔMICAS } \\
\hline Católico & $\begin{array}{c}1,876\left(^{* *}\right) \\
(0,09)\end{array}$ & $\begin{array}{c}1,356\left(^{* *}\right) \\
(0,09)\end{array}$ & $\begin{array}{c}1,707(* \star \\
(0,11) \\
\end{array}$ & $\begin{array}{l}0,932 \\
(0,09)\end{array}$ \\
\hline $\mathrm{R}^{2}$ & 0,03 & 0,01 & 0,02 & 0 \\
\hline $\mathrm{N}$ & 2.514 & 2.514 & 1.600 & 2.400 \\
\hline Casos previstos corretamente & $57 \%$ & $55 \%$ & $56 \%$ & $56 \%$ \\
\hline Votos no PT previstos corretamente & $0 \%$ & $73 \%$ & $75 \%$ & $100 \%$ \\
\hline Previsões de voto no PT corretas & $0 \%$ & $57 \%$ & $55 \%$ & $56 \%$ \\
\hline Chance na base & $32 \%$ & $49 \%$ & $42 \%$ & $57 \%$ \\
\hline
\end{tabular}

Notas: $\left(^{a}\right)$ A variável religião foi operacionalizada da seguinte forma: não católico $=0$; católico $=1$. $\left({ }^{*}\right) p<0,05 .\left({ }^{* *}\right) p<0,01$.

Fonte: 2002: Almeida et al. (2002); 2006: Analítica Consultoria (2006).

\subsubsection{Região}

A literatura sobre o comportamento político e eleitoral considera a região onde vive o eleitor como uma das variáveis mais importantes. Esse conceito pode ser operacionalizado de muitas maneiras. Pode ser a oposição entre eleitores da área rural e da área urbana, tal como ocorre nos trabalhos da escola sociológica e sugerem Castro (1994) e Reis (org., 1978); pode ser a distinção entre os eleitores do Norte e do Sul dos EUA, como observado em Miller \& Shanks (1996). Essas mesmas diferenças regionais podem ser observadas em países como a Itália, o Canadá, a Alemanha e o Brasil.

Por aqui também muitos pesquisadores incluíram uma análise regional do comportamento eleitoral. Os trabalhos mais importantes são o de Soares (1973), que compara resultados eleitorais entre um Brasil desenvolvido, o Sudeste, e um Brasil subdesenvolvido, o restante do país, e o de Reis (1976), que em seu modelo de centralidade considera a dimensão rural e urbana. Aqui, a variável será vista, comparando-se as chances de voto no PSDB e no PT nas cinco regiões do país.

Nos modelos do PSDB (ver Quadro 15, a seguir), o traço distintivo são as chances de voto sempre menores no Nordeste, quando comparadas com as do Norte ou do Norte/Centro-Oeste (ver nota no Quadro 15). Essas diferenças são significantes ao nível de $1 \%$ em todas as eleições analisadas, exceto no primeiro turno de 2002. Via de regra, a probabilidade de um eleitor nordestino votar no 
PSDB é cerca da metade da observada para um eleitor do Norte ou do Norte/Centro-Oeste. Quanto às outras regiões, não existe um padrão de comportamento: em algumas ocasiões, o partido tem melhor desempenho e em outras tem pior, em alguma região; em geral, as diferenças não são significativas.

Quadro 15: Modelo de regressão logística para a ocorrência de voto no PSDB - Região $\left({ }^{a}\right)$

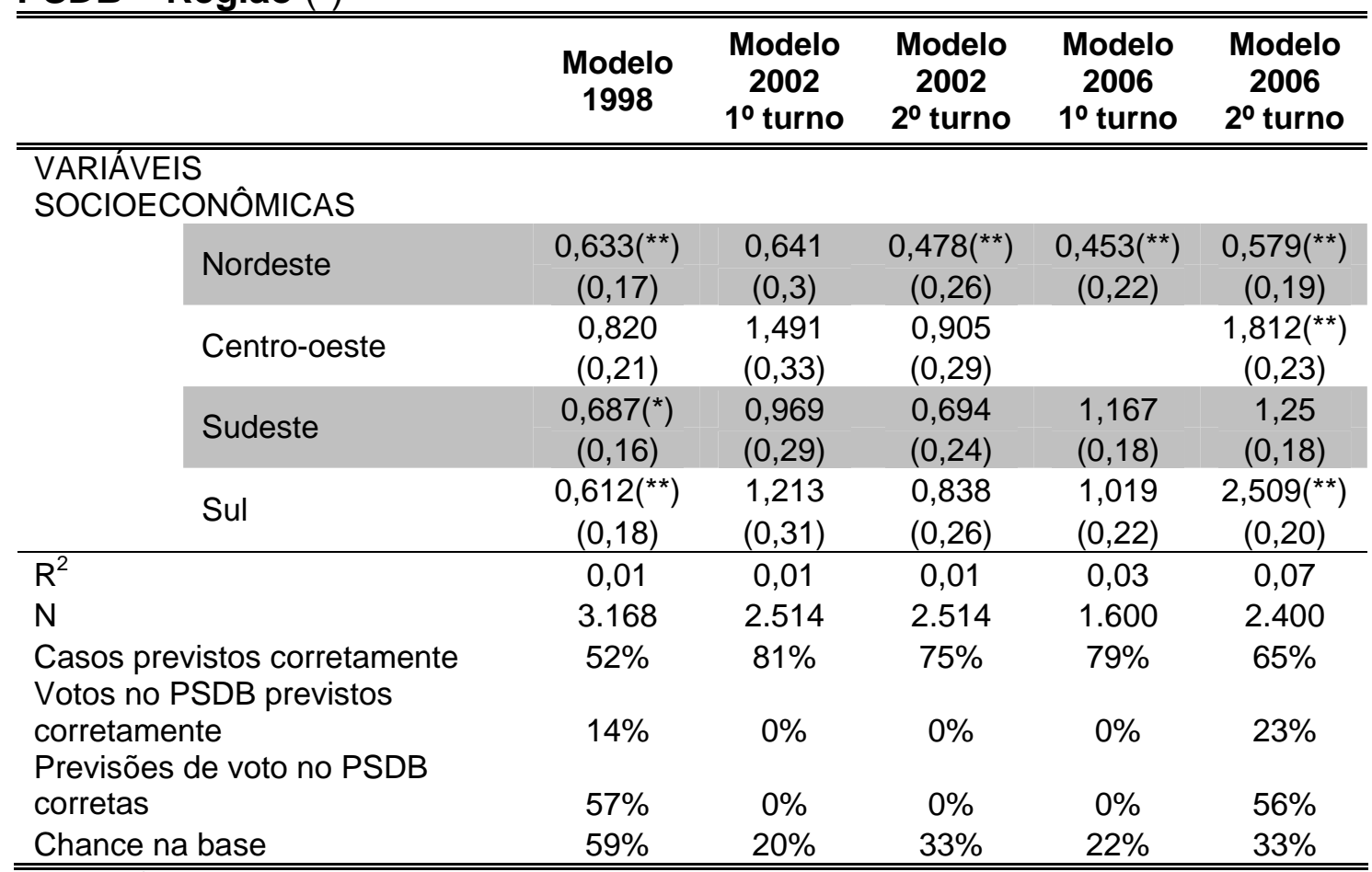

Notas: $\left({ }^{a}\right)$ A variável região foi operacionalizada tendo como base a região Norte, exceto para o modelo referente ao primeiro turno de 2006, que tem como base as regiões Norte e CentroOeste. As variáveis referentes às demais regiões são indicadoras. $\left({ }^{\star}\right) p<0,05 .\left({ }^{\star *}\right) p<0,01$.

Fonte: 1998: Vox Populi (1998); 2002: Almeida et al. (2002); 2006: Analítica Consultoria (2006).

Apenas no segundo turno de 2006 é que, aparentemente, ocorre uma diferença regional importante: as razões de chance são significantes ao nível de 1\% para as diferenças entre as probabilidades de voto no PSDB no Nordeste $(0,579)$, no Centro-Oeste $(1,812)$ e no Sul $(2,509)$, quando comparadas ao Norte.

Ao contrário do PSDB, o PT sempre tem melhores chances de voto no Nordeste, quando comparado ao Norte ou Norte/Centro-Oeste (ver Quadro 16, a seguir). Contudo, essas diferenças foram significantes ao nível de 1\% apenas nos dois turnos de 2006. Nesses pleitos, as diferenças regionais em relação à ocorrência de voto no PT foram importantes. No segundo turno, as razões de chance indicam maior probabilidade de voto no partido no Nordeste 
$(1,714)$ e menores no Centro-Oeste $(0,475)$, no Sul $(0,347)$ e no Sudeste $(0,66)$ — neste último caso ao nível de significância de 5\%.

Quadro 16: Modelo de regressão logística para a ocorrência de voto no PT - Região $\left({ }^{\mathrm{a}}\right)$

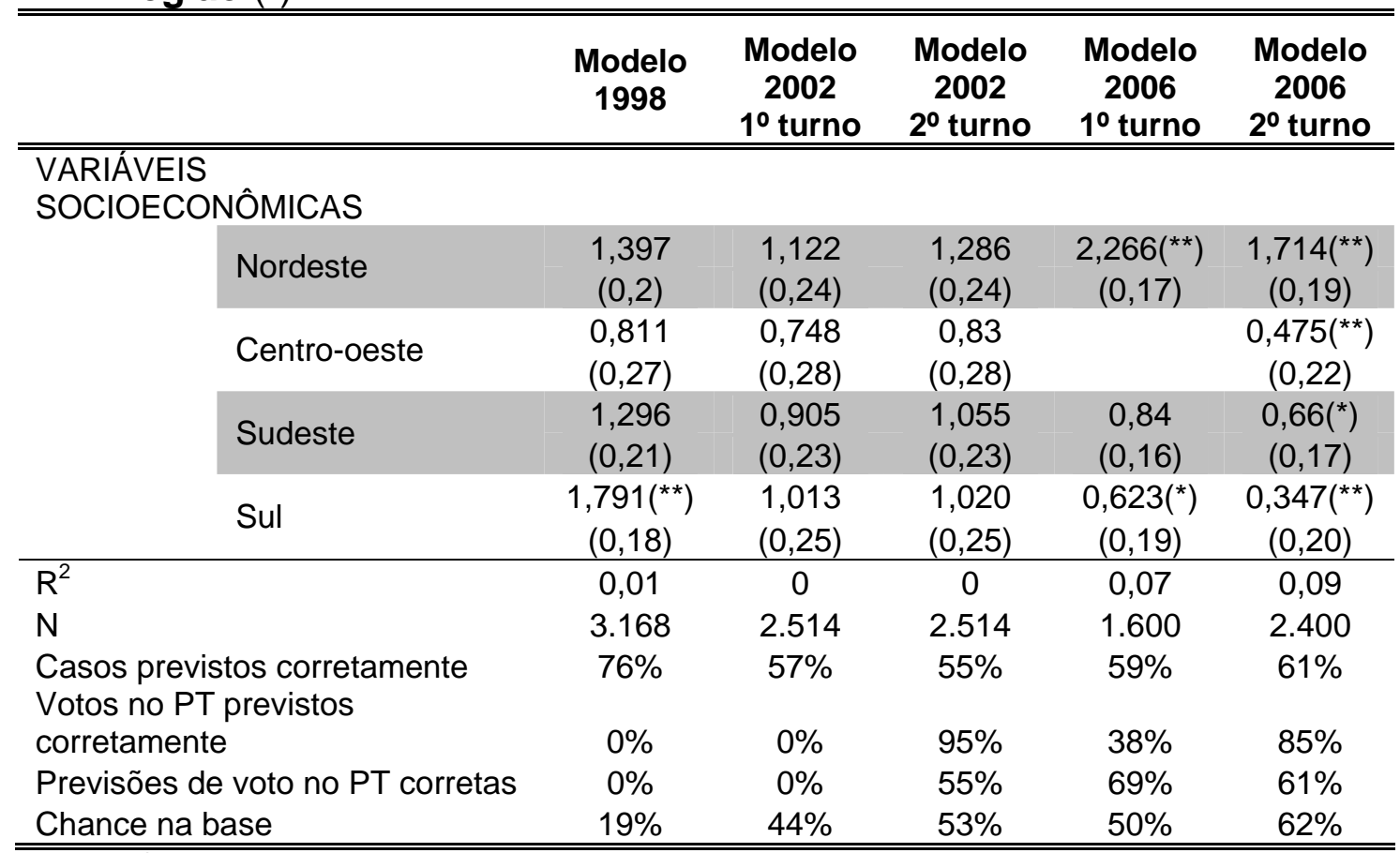

Notas: $\left({ }^{\mathrm{a}}\right)$ A variável região foi operacionalizada tendo como base a região Norte, exceto para o modelo referente ao primeiro turno de 2006, que tem como base as regiões Norte e CentroOeste. As variáveis referentes às demais regiões são indicadoras. $\left(^{\star}\right) p<0,05 .\left({ }^{\star \star}\right) p<0,01$.

Fonte: 1998: Vox Populi (1998); 2002: Almeida et al. (2002); 2006: Analítica Consultoria (2006).

Comparando os modelos do PSDB e do PT, pode-se observar que existem diferenças notáveis entre os desempenhos dos dois partidos nas diferentes regiões do país. A mais importante é observada no Nordeste, onde o PSDB tem sempre pior desempenho e o PT melhor, ainda que essas diferenças não tenham sido sempre estatisticamente significantes. Além disso, em 2006, especialmente no segundo turno, ocorreu uma aparente polarização regional entre os partidos, com o PSDB melhor no Centro-Oeste e no Sul e o PT melhor no Nordeste e no Norte. Os dados permitem indicar que a diferença regional é variável que deve ser considerada nas análises sobre o comportamento eleitoral nas eleições presidenciais.

Além disso, de todos os modelos até aqui abordados, aqueles que têm como covariável a região foram os que apresentaram os maiores $R^{2}$, mas que ainda assim não ultrapassam o valor 0,1. 


\subsubsection{Tipo de cidade}

Outra forma de avaliar os possíveis impactos do local onde vive o eleitor é considerar o tipo de cidade em que ele está inserido. Não se trata de opor o mundo rural do mundo urbano - uma vez que tais distinções perdem sentido em um país cada vez mais urbano como o Brasil —, mas de observar como eleitores de diferentes contextos urbanos se posicionam frente aos partidos na disputa presidencial. As categorias analisadas nesse caso são capitais e regiões metropolitanas. O que se espera encontrar é melhor desempenho do PT nesses casos em comparação a outros tipos de cidade, uma vez que o partido surgiu nas capitais e grandes cidades das regiões metropolitanas, caso do ABCD paulista.

Os modelos do PSDB indicam que o partido tem sempre desempenho pior em capitais e regiões metropolitanas, em comparação com outros tipos de cidade (ver Quadro 17). Em todos os pleitos existem diferenças significativas entre as probabilidades de voto no partido de acordo com o tipo da cidade. Isso é particularmente mais visível nos dois turnos da eleição de 2002, quando a chance de voto do partido em regiões metropolitanas foi cerca de metade da observada nas demais cidades.

Quadro 17: Modelo de regressão logística para a ocorrência de voto no PSDB - Tipo de cidade

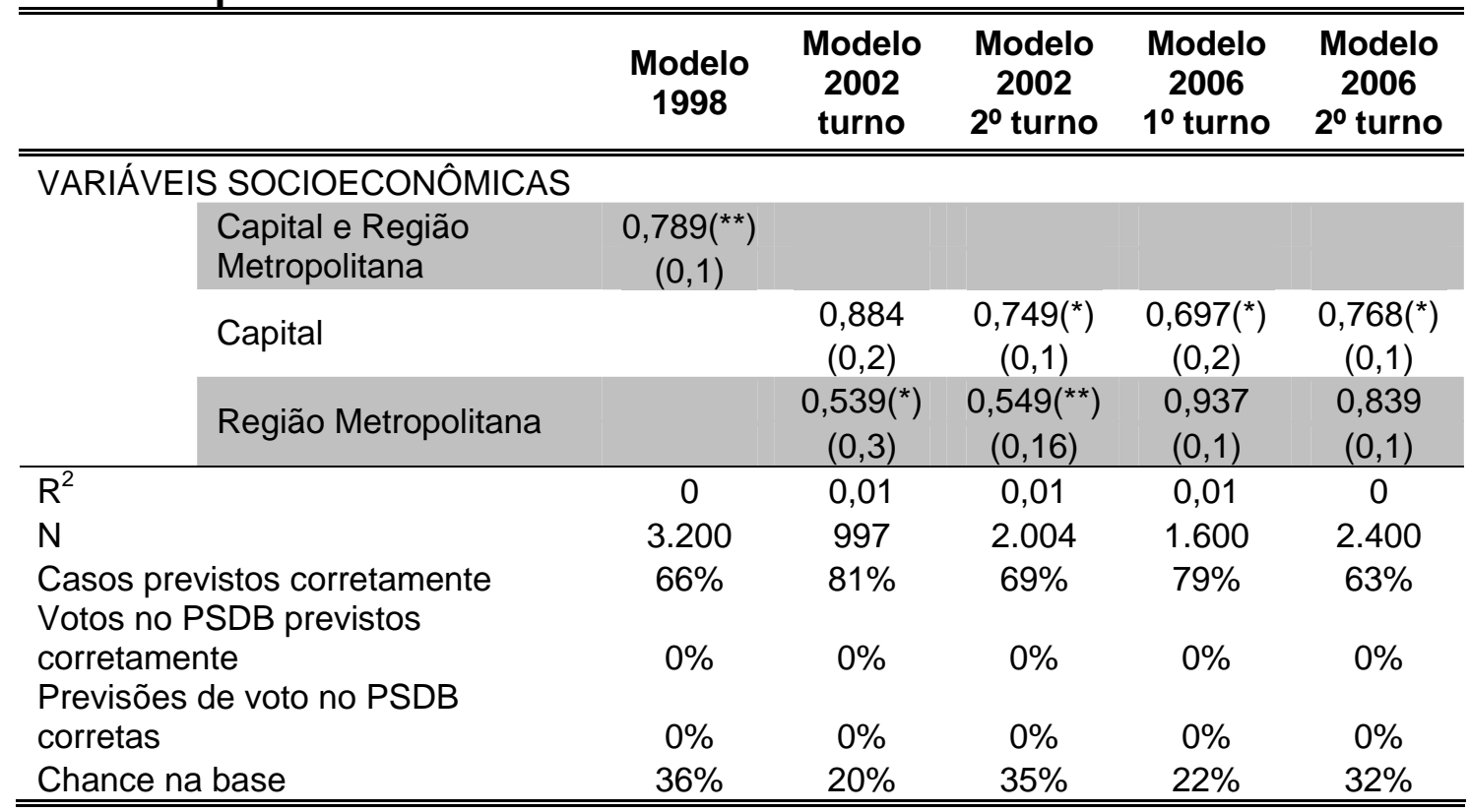

Notas: $\left(^{\star}\right) p<0,05 .\left({ }^{* \star}\right) p<0,01$.

Fonte: 1998: Vox Populi (1998); 2002: Almeida et al. (2002); 2006: Analítica Consultoria (2006). 
Nos modelos para a ocorrência de voto no PT, todas as razões de chance, exceto no primeiro turno de 2006, indicam melhores chances de voto nas capitais e nas regiões metropolitanas (ver Quadro 18). Cabe destacar que as razões de chance são significativas ao nível de 1\% em 1998 e no segundo turno de 2002. Em 2006, as razões de chance não permitem uma análise conclusiva, uma vez que as chances de voto no PT nas capitais são menores no primeiro turno e maiores no segundo, ambas ao nível de 5\%.

Tanto os modelos para o PSDB, como os para o PT, apresentam $\mathrm{R}^{2}$ muito baixos e poder preditivo quase nulo.

Quadro 18: Modelo de regressão logística para a ocorrência de voto no PT - Tipo de cidade

\begin{tabular}{|c|c|c|c|c|c|}
\hline & $\begin{array}{l}\text { Modelo } \\
1998\end{array}$ & $\begin{array}{c}\text { Modelo } \\
2002 \\
1^{\circ} \text { turno } \\
\end{array}$ & $\begin{array}{c}\text { Modelo } \\
2002 \\
2^{\circ} \text { turno } \\
\end{array}$ & $\begin{array}{c}\text { Modelo } \\
2006 \\
1^{\circ} \text { turno } \\
\end{array}$ & $\begin{array}{c}\text { Modelo } \\
2006 \\
2^{\circ} \text { turno } \\
\end{array}$ \\
\hline \multicolumn{6}{|l|}{ VARIÁVEIS SOCIOECONÔMICAS } \\
\hline $\begin{array}{l}\text { Capital e Região } \\
\text { Metropolitana }\end{array}$ & $\begin{array}{c}1,295(* *) \\
(0,08)\end{array}$ & & & & \\
\hline Capital & & $\begin{array}{c}1,298 \\
(0,2)\end{array}$ & $\begin{array}{c}1,337(* *) \\
(0,1)\end{array}$ & $\begin{array}{c}0,79\left(^{*}\right) \\
(0,1)\end{array}$ & $\begin{array}{c}1,278(*) \\
(0,1)\end{array}$ \\
\hline Região Metropolitana & & $\begin{array}{c}1,155 \\
(0,2)\end{array}$ & $\begin{array}{c}1,651(* *) \\
(0,15)\end{array}$ & $\begin{array}{l}0,965 \\
(0,2)\end{array}$ & $\begin{array}{c}1,184 \\
(0,1) \\
\end{array}$ \\
\hline $\mathrm{R}^{2}$ & 0,04 & 0 & 0,01 & 0 & 0 \\
\hline $\mathrm{N}$ & 3.200 & 997 & 2.004 & 1.600 & 2.400 \\
\hline Casos previstos corretamente & $75 \%$ & $56 \%$ & $60 \%$ & $53 \%$ & $56 \%$ \\
\hline Votos no PT previstos corretamente & $0 \%$ & $0 \%$ & $100 \%$ & $77 \%$ & $100 \%$ \\
\hline Previsões de voto no PT corretas & $0 \%$ & $0 \%$ & $60 \%$ & $53 \%$ & $59 \%$ \\
\hline Chance na base & $23 \%$ & $42 \%$ & $57 \%$ & $53 \%$ & $54 \%$ \\
\hline
\end{tabular}

Notas: $\left({ }^{\star}\right) p<0,05 .\left({ }^{*}\right) p<0,01$.

Fonte: 1998: Vox Populi (1998); 2002: Almeida et al. (2002); 2006: Analítica Consultoria (2006).

\subsection{Vista geral sobre os modelos socioeconômicos bivariados}

Foram apresentados 18 quadros com modelos logísticos bivariados, dos quais nove para a ocorrência de voto no PSDB e nove para a ocorrência de voto no PT. O aspecto mais importante a ser destacado é a aparente metamorfose da base eleitoral petista de 1994 até 2006, especialmente na passagem da oposição para o governo. Nas eleições de 1994, 1998 e 2002, as chances de voto no partido tendem a ser maiores entre os mais escolarizados, entre os mais jovens, entre os trabalhadores e entre os católicos. Na eleição de 2006, quando conquista a Presidência da República, as chances de voto no PT tornam-se 
maiores entre os menos escolarizados, entre os mais velhos, entre os de menor renda, entre os não brancos. Os aspectos que permanecem nesse período são as maiores probabilidades de voto entre homens e entre católicos.

Quanto ao PSDB, a passagem do governo à oposição não fez mudar significativamente a composição de seu eleitorado. O partido sempre obteve maiores chances entre os eleitores de maior renda e brancos e menores chances no Nordeste e nas capitais e regiões metropolitanas. A escolaridade passou a ser significante em 2006, o que indica maior probabilidade entre os mais escolarizados. O sexo e a idade do eleitor são variáveis que ora atuam em um sentido, ora em outro, o que não permite considerações conclusivas.

Também foi possível observar uma provável polarização nos dois turnos de 2006 entre PSDB e PT no que diz respeito às variáveis escolaridade, renda, etnia e região. As chances tucanas tornaram-se significativamente maiores entre os mais escolarizados, os de maior renda, os brancos e nas regiões Sul e CentroOeste. As chances petistas cresceram entre os menos escolarizados, os de menor renda, os não brancos e nas regiões Nordeste e Norte.

Tomadas isoladamente, nenhuma variável apresentou algum impacto em um mesmo sentido para os dois partidos no conjunto das eleições. Todas as variáveis ou não exerceram impacto significativo ou trocaram de sinal. Portanto, a princípio não faz sentido falar em bases eleitorais demográficas e socioeconômicas dos partidos. Contudo, para uma conclusão mais segura, é necessário estudar os modelos para a ocorrência de voto em PSDB e PT com o conjunto das variáveis socioeconômicas.

\subsection{Modelos logísticos com o conjunto de variáveis socioeconômicas}

Após o exame das regressões bivariadas para a ocorrência de intenção de voto no PSDB e no PT, cabe agora recorrer à principal qualidade do tipo de modelagem de dados utilizado nesta tese, para considerar simultaneamente todas as covariáveis socioeconômicas.

Quanto aos modelos para o PSDB, sem considerar níveis de significância, vemos que o partido sempre teve menores chances de intenção de voto no Sudeste e Sul, em relação a Norte ou Norte/Centro-Oeste, e em capitais e regiões metropolitanas, em comparação com outros tipos de cidade (ver Quadro 19). 
Quadro 19: Modelo de regressão logística para a ocorrência de voto no PSDB - Conjunto das variáveis socioeconômicas

\begin{tabular}{|c|c|c|c|c|c|c|c|}
\hline & & $\begin{array}{l}\text { Modelo } \\
1994\end{array}$ & $\begin{array}{l}\text { Modelo } \\
1998\end{array}$ & $\begin{array}{l}\text { Modelo } \\
2002 \\
1^{\circ} \text { turno } \\
\end{array}$ & $\begin{array}{l}\text { Modelo } \\
2002 \\
2^{\circ} \text { turno } \\
\end{array}$ & $\begin{array}{l}\text { Modelo } \\
2006 \\
1^{\circ} \text { turno } \\
\end{array}$ & $\begin{array}{l}\text { Modelo } \\
2006 \\
2^{\circ} \text { turno } \\
\end{array}$ \\
\hline \multicolumn{8}{|c|}{$\begin{array}{l}\text { VARIÁVEIS } \\
\text { SOCIOECONÔMICAS }\end{array}$} \\
\hline & Sexo: masculino & $\begin{array}{c}1,183 \\
(0,1)\end{array}$ & $\begin{array}{c}1,19\left(^{*}\right) \\
(0,1)\end{array}$ & $\begin{array}{c}0,909 \\
(0,1)\end{array}$ & $\begin{array}{c}0,826 \\
(0,1)\end{array}$ & $\begin{array}{c}0,843 \\
(0,1)\end{array}$ & $\begin{array}{c}0,599(* \star) \\
(0,1)\end{array}$ \\
\hline & $\begin{array}{l}\text { Idade: faixas } \\
\text { etárias }\end{array}$ & $\begin{array}{l}0,986 \\
(0,03)\end{array}$ & $\begin{array}{c}0,927\left({ }^{* \star}\right) \\
(0,03)\end{array}$ & $\begin{array}{c}1,131(* *) \\
(0,04)\end{array}$ & $\begin{array}{c}1,119\left(^{\star \star}\right) \\
(0,04)\end{array}$ & $\begin{array}{c}0,95 \\
(0,06)\end{array}$ & $\begin{array}{l}0,937 \\
(0,05)\end{array}$ \\
\hline & $\begin{array}{l}\text { Escolaridade: } \\
\text { mais } \\
\text { escolarizados }\end{array}$ & $\begin{array}{c}0,779\left(^{*}\right) \\
(0,1)\end{array}$ & $\begin{array}{l}0,861 \\
(0,1)\end{array}$ & $\begin{array}{l}1,019 \\
(0,1)\end{array}$ & $\begin{array}{l}1,035 \\
(0,1)\end{array}$ & $\begin{array}{l}1,327 \\
(0,2)\end{array}$ & $\begin{array}{l}1,149 \\
(0,1)\end{array}$ \\
\hline \multicolumn{2}{|r|}{$\begin{array}{l}\text { Renda familiar de } \\
\text { cinco salários } \\
\text { mínimos ou mais }\end{array}$} & $\begin{array}{c}1,258\left(^{*}\right) \\
(0,1)\end{array}$ & $\begin{array}{c}1,183\left(^{*}\right) \\
(0,1)\end{array}$ & $\begin{array}{c}1,309\left(^{*}\right) \\
(0,1)\end{array}$ & $\begin{array}{c}1,596\left(^{* \star}\right) \\
(0,1)\end{array}$ & $\begin{array}{l}1,15 \\
(0,2)\end{array}$ & $\begin{array}{l}1,328 \\
(0,2)\end{array}$ \\
\hline \multicolumn{2}{|r|}{ PEA } & & & $\begin{array}{l}0,965 \\
(0,1)\end{array}$ & $\begin{array}{c}0,979 \\
(0,1)\end{array}$ & $\begin{array}{l}0,893 \\
(0,2)\end{array}$ & $\begin{array}{c}1,135 \\
(0,1)\end{array}$ \\
\hline \multicolumn{2}{|r|}{ Branco } & $\begin{array}{l}0,997 \\
(0,04)\end{array}$ & & $\begin{array}{c}1,26\left(^{*}\right) \\
(0,1)\end{array}$ & $\begin{array}{c}1,052 \\
(0,1)\end{array}$ & $\begin{array}{c}1,626(* *) \\
(0,1)\end{array}$ & $\begin{array}{c}1,646(* \star) \\
(0,1)\end{array}$ \\
\hline \multicolumn{2}{|r|}{ Católico } & & & $\begin{array}{c}1,675(* *) \\
(0,1)\end{array}$ & $\begin{array}{l}1,03 \\
(0,1)\end{array}$ & $\begin{array}{l}0,945 \\
(0,1)\end{array}$ & $\begin{array}{c}0,941 \\
(0,1)\end{array}$ \\
\hline \multicolumn{2}{|r|}{ Nordeste } & & $\begin{array}{c}0,597(* *) \\
(0,2)\end{array}$ & $\begin{array}{c}0,579 \\
(0,3)\end{array}$ & $\begin{array}{c}0,492(* *) \\
(0,3)\end{array}$ & $\begin{array}{c}0,416(* \star) \\
(0,2)\end{array}$ & $\begin{array}{c}0,358\left(^{* \star}\right) \\
(0,2)\end{array}$ \\
\hline \multicolumn{2}{|r|}{ Centro-Oeste } & & $\begin{array}{c}0,872 \\
(0,2)\end{array}$ & $\begin{array}{c}1,304 \\
(0,3)\end{array}$ & $\begin{array}{l}0,805 \\
(0,3)\end{array}$ & & \\
\hline \multicolumn{2}{|r|}{ Sudeste } & & $\begin{array}{c}0,706\left(^{*}\right) \\
(0,2)\end{array}$ & $\begin{array}{l}0,806 \\
(0,3)\end{array}$ & $\begin{array}{l}0,617 \\
(0,3)\end{array}$ & $\begin{array}{c}0,941 \\
(0,2)\end{array}$ & $\begin{array}{c}0,784 \\
(0,2)\end{array}$ \\
\hline \multicolumn{2}{|r|}{ Sul } & & $\begin{array}{c}0,613\left({ }^{* *}\right) \\
(0,2)\end{array}$ & $\begin{array}{l}0,888 \\
(0,3)\end{array}$ & $\begin{array}{l}0,712 \\
(0,3)\end{array}$ & $\begin{array}{l}0,751 \\
(0,2)\end{array}$ & $\begin{array}{l}0,936 \\
(0,2)\end{array}$ \\
\hline \multicolumn{2}{|r|}{$\begin{array}{l}\text { Capital e região } \\
\text { metropolitana }\end{array}$} & & $\begin{array}{c}0,765\left(^{* \star}\right) \\
(0,2)\end{array}$ & & & & \\
\hline \multicolumn{2}{|r|}{ Capital } & & & $\begin{array}{c}0,802 \\
(0,1)\end{array}$ & $\begin{array}{c}0,895 \\
(0,1)\end{array}$ & $\begin{array}{c}0,636\left(^{* \star}\right) \\
(0,2)\end{array}$ & $\begin{array}{l}0,859 \\
(0,1)\end{array}$ \\
\hline \multicolumn{2}{|r|}{$\begin{array}{l}\text { Região } \\
\text { metropolitana }\end{array}$} & & & & & $\begin{array}{c}0,897 \\
(0,2) \\
\end{array}$ & $\begin{array}{c}0,977 \\
(0,2)\end{array}$ \\
\hline & 0,01 & 0,02 & 0,04 & 0,03 & 0,07 & 0,1 \\
\hline \multicolumn{2}{|c|}{$\mathrm{N}$} & 2.145 & 3.154 & 2.514 & 2.514 & 1.453 & 1.453 \\
\hline \multicolumn{2}{|c|}{$\begin{array}{l}\text { Casos previstos } \\
\text { corretamente }\end{array}$} & $54 \%$ & $66 \%$ & $81 \%$ & $75 \%$ & $80 \%$ & $71 \%$ \\
\hline \multicolumn{2}{|c|}{ previstos corretamente } & $19 \%$ & $1 \%$ & $0 \%$ & $0 \%$ & $0 \%$ & $12 \%$ \\
\hline \multirow{2}{*}{\multicolumn{2}{|c|}{ PSDB corretas }} & $53 \%$ & $52 \%$ & $0 \%$ & $0 \%$ & $0 \%$ & $62 \%$ \\
\hline & Chance na base & $45 \%$ & $48 \%$ & $14 \%$ & $28 \%$ & $26 \%$ & $39 \%$ \\
\hline
\end{tabular}

Notas: $\left(^{\star}\right) p<0,05 .\left(^{\star \star}\right) p<0,01$.

Fonte: 1994: Datafolha (1994); 1998: Vox Populi (1998); 2002: Almeida et al. (2002); 2006: Analítica Consultoria (2006).

Algumas características importantes, como sexo, idade e escolaridade, exercem efeitos diferentes sobre as chances de voto em cada eleição. Até 1998, as chances de voto no PSDB eram maiores entre os homens e tornaram-se maiores entre as mulheres a partir de 2002. As chances de voto 
cresceram junto com a idade do eleitor apenas nos dois turnos de 2002; nas outras eleições, ocorreu o inverso. A religião indica maior apoio entre os católicos apenas no primeiro turno de 2002.

A análise dos $\mathrm{R}^{2}$ e dos índices de previsões corretas revelam que os modelos socioeconômicos têm baixo poder explicativo e preditivo. Ou seja, conhecer a condição socioeconômica dos eleitores não ajuda muito a compreender seu comportamento em relação ao PSDB. Cabe destacar que, até aqui, o melhor modelo para explicar e prever a intenção de voto no partido é o do segundo turno da eleição em 2006, quando as chances de intenção de voto no partido foram muito superiores entre as mulheres, os brancos e nas regiões Norte/Centro-Oeste.

Os modelos para a ocorrência de intenção de voto no PT mostram que, independentemente do nível de significância, o partido sempre tendeu a ser melhor entre os homens, entre os católicos e na região Nordeste (ver Quadro 20, a seguir). Em todas as eleições, as razões de chance para essas variáveis são maiores que um. Por outro lado, o partido sempre teve piores chances na região Centro-Oeste.

O que mais chama a atenção com relação aos modelos do partido é a inversão nas razões de chance de voto em seis das 14 categorias apresentadas no Quadro 20, quando o partido disputa a reeleição. Até 2002, o partido obtinha melhores chances entre os mais jovens, os mais escolarizados, os pertencentes à PEA, na região Sul e nas capitais e regiões metropolitanas. $\mathrm{Na}$ eleição de 2006, essas chances invertem-se, e o partido passa a obter melhores resultados entre os mais velhos, os menos escolarizados, os que estão fora da PEA, fora da região Sul e fora das capitais e regiões metropolitanas. Isso significa que ocorreu uma transformação profunda na base de apoio socioeconômico do partido quando este se tornou governo. Esse aspecto fica evidenciado quando observamos os valores dos $\mathrm{R}^{2} \mathrm{e}$ os percentuais de previsões de voto corretas. No caso petista de 2006, obtêm-se os maiores $\mathrm{R}^{2}$ dos modelos desse capítulo, que atingem 0,15 no primeiro turno e 0,13 no segundo turno. Também são nesses dois turnos que encontramos os melhores modelos preditivos, com mais de dois terços de previsões de voto 
corretas. Todavia, assim como no caso do PSDB, não se pode falar na existência de uma base socioeconômica de voto no PT.

Quadro 20: Modelo de regressão logística para a ocorrência de voto no PT - Conjunto das variáveis socioeconômicas

\begin{tabular}{|c|c|c|c|c|c|c|}
\hline & $\begin{array}{c}\text { Modelo } \\
1994\end{array}$ & $\begin{array}{c}\text { Modelo } \\
1998\end{array}$ & $\begin{array}{l}\text { Modelo } \\
2002 \\
1^{\circ} \text { turno }\end{array}$ & $\begin{array}{l}\text { Modelo } \\
2002 \\
2^{\circ} \text { turno }\end{array}$ & $\begin{array}{l}\text { Modelo } \\
2006 \\
1^{\circ} \text { turno }\end{array}$ & $\begin{array}{l}\text { Modelo } \\
2006 \\
2^{\circ} \text { turno }\end{array}$ \\
\hline \multicolumn{7}{|l|}{$\begin{array}{l}\text { VARIÁVEIS } \\
\text { SOCIOECONÔMICAS }\end{array}$} \\
\hline Sexo & $\begin{array}{c}1,222 \\
(0,1)\end{array}$ & $\begin{array}{l}1,08 \\
(0,1)\end{array}$ & $\begin{array}{c}1,107 \\
(0,1)\end{array}$ & $\begin{array}{c}1,074 \\
(0,1)\end{array}$ & $\begin{array}{c}1,8(* *) \\
(0,1)\end{array}$ & $\begin{array}{c}1,709(* *) \\
(0,1)\end{array}$ \\
\hline Idade & $\begin{array}{c}0,875(* *) \\
(0,04)\end{array}$ & $\begin{array}{c}0,916\left({ }^{* *}\right) \\
(0,03)\end{array}$ & $\begin{array}{c}0,927\left(^{*}\right) \\
(0,04)\end{array}$ & $\begin{array}{l}0,953 \\
(0,03)\end{array}$ & $\begin{array}{l}1,037 \\
(0,05)\end{array}$ & $\begin{array}{l}1,057 \\
(0,05)\end{array}$ \\
\hline $\begin{array}{l}\text { Escolaridade: } \\
\text { mais } \\
\text { escolarizados }\end{array}$ & $\begin{array}{c}1,567\left(^{\star *}\right) \\
(0,1)\end{array}$ & $\begin{array}{l}1,069 \\
(0,1)\end{array}$ & $\begin{array}{l}1,055 \\
(0,1)\end{array}$ & $\begin{array}{l}1,16 \\
(0,1)\end{array}$ & $\begin{array}{c}0,704(* *) \\
(0,1)\end{array}$ & $\begin{array}{c}0,762\left(^{*}\right) \\
(0,1)\end{array}$ \\
\hline $\begin{array}{l}\text { Renda familiar de } \\
\text { cinco salários } \\
\text { mínimos ou mais }\end{array}$ & $\begin{array}{c}0,928 \\
(0,1)\end{array}$ & $\begin{array}{c}0,708(* \star) \\
(0,09)\end{array}$ & $\begin{array}{l}0,994 \\
(0,1)\end{array}$ & $\begin{array}{c}0,931 \\
(0,1)\end{array}$ & $\begin{array}{c}0,833 \\
(0,2)\end{array}$ & $\begin{array}{l}0,965 \\
(0,2)\end{array}$ \\
\hline PEA & & & $\begin{array}{c}1,275\left(^{*}\right) \\
(0,1)\end{array}$ & $\begin{array}{c}1,357\left(^{* *}\right) \\
(0,1)\end{array}$ & $\begin{array}{c}0,975 \\
(0,1)\end{array}$ & $\begin{array}{l}1,011 \\
(0,1)\end{array}$ \\
\hline Branco & $\begin{array}{l}0,916 \\
(0,01)\end{array}$ & & $\begin{array}{c}0,9 \\
(0,1)\end{array}$ & $\begin{array}{c}0,892 \\
(0,1)\end{array}$ & $\begin{array}{c}0,605\left(^{* *}\right) \\
(0,1)\end{array}$ & $\begin{array}{c}0,588(* *) \\
(0,1)\end{array}$ \\
\hline Católico & & & $\begin{array}{c}1,903\left({ }^{* \star}\right) \\
(0,1)\end{array}$ & $\begin{array}{c}1,384(* \star) \\
(0,1)\end{array}$ & $\begin{array}{c}1,754(* *) \\
(0,1)\end{array}$ & $\begin{array}{c}1,481(* *) \\
(0,1)\end{array}$ \\
\hline Nordeste & & $\begin{array}{c}1,217 \\
(0,2)\end{array}$ & $\begin{array}{c}1,063 \\
(0,2)\end{array}$ & $\begin{array}{c}1,288 \\
(0,2)\end{array}$ & $\begin{array}{c}2,156\left(^{* *}\right) \\
(0,2)\end{array}$ & $\begin{array}{c}2,264(* *) \\
(0,2)\end{array}$ \\
\hline Centro-Oeste & & $\begin{array}{l}0,914 \\
(0,2)\end{array}$ & $\begin{array}{l}0,759 \\
(0,3)\end{array}$ & $\begin{array}{l}0,86 \\
(0,3)\end{array}$ & & \\
\hline Sudeste & & $\begin{array}{l}0,976 \\
(0,2)\end{array}$ & $\begin{array}{l}0,975 \\
(0,2)\end{array}$ & $\begin{array}{c}1,148 \\
(0,2)\end{array}$ & $\begin{array}{l}0,97 \\
(0,2)\end{array}$ & $\begin{array}{c}1,006 \\
(0,2)\end{array}$ \\
\hline Sul & & $\begin{array}{c}1,247 \\
(0,2)\end{array}$ & $\begin{array}{l}1,001 \\
(0,3)\end{array}$ & $\begin{array}{l}1,077 \\
(0,3)\end{array}$ & $\begin{array}{c}0,701 \\
(0,2)\end{array}$ & $\begin{array}{l}0,81 \\
(0,2)\end{array}$ \\
\hline $\begin{array}{l}\text { Capital e região } \\
\text { metropolitana }\end{array}$ & & $\begin{array}{c}1,425(* *) \\
(0,1)\end{array}$ & & & & \\
\hline Capital & & & $\begin{array}{l}0,929 \\
(0,1)\end{array}$ & $\begin{array}{c}1,031 \\
(0,1)\end{array}$ & $\begin{array}{l}0,868 \\
(0,1)\end{array}$ & $\begin{array}{l}0,856 \\
(0,1)\end{array}$ \\
\hline $\begin{array}{l}\text { Região } \\
\text { metropolitana }\end{array}$ & & & & & $\begin{array}{c}1,113 \\
(0,2)\end{array}$ & $\begin{array}{l}0,95 \\
(0,2) \\
\end{array}$ \\
\hline $\mathrm{R}^{2}$ & 0,03 & 0,02 & 0,04 & 0,02 & 0,15 & 0,13 \\
\hline $\mathrm{N}$ & 2.145 & 3.154 & 2.514 & 2.514 & 1.453 & 1.453 \\
\hline $\begin{array}{l}\text { Casos previstos } \\
\text { corretamente } \\
\text { Votos no PT previstos }\end{array}$ & $78 \%$ & $75 \%$ & $58 \%$ & $57 \%$ & $64 \%$ & $63 \%$ \\
\hline $\begin{array}{l}\text { corretamente } \\
\text { Previsões de voto no }\end{array}$ & $0 \%$ & $0 \%$ & $30 \%$ & $79 \%$ & $67 \%$ & $75 \%$ \\
\hline PT corretas & $0 \%$ & $0 \%$ & $52 \%$ & $58 \%$ & $65 \%$ & $66 \%$ \\
\hline Chance na base & $25 \%$ & $27 \%$ & $32 \%$ & $42 \%$ & $40 \%$ & $47 \%$ \\
\hline
\end{tabular}

Notas: $\left.\left(^{\star}\right) p<0,05 .{ }^{* *}\right) p<0,01$.

Fonte: 1994: Datafolha (1994); 1998: Vox Populi (1998); 2002: Almeida et al. (2002); 2006: Analítica Consultoria (2006). 
Considerando os dois modelos, as únicas variáveis que mantêm em todas as eleições e para os dois partidos alguma influência no mesmo sentido são a renda familiar, a cor da pele e a região Nordeste. O PSDB sempre teve melhores chances de voto entre os de maior renda familiar e os brancos e sempre teve piores chances na região Nordeste. O PT, por sua vez, é sempre melhor entre os de menor renda, os não-brancos e no Nordeste. Assim, se é possível falar em diferenças entre os eleitores de PSDB e PT, elas residem nessas características. Contudo, em muitas ocasiões, essas diferenças não são estatisticamente significantes, o que nos dá segurança para afirmar que não existem bases socioeconômicas dos partidos que perdurem ao longo do tempo.

Para encerrar a análise dos efeitos das variáveis demográficas e socioeconômicas sobre o comportamento eleitoral, cabe destacar que, em 2006, fica aparente a polarização social entre as candidaturas tucana e petista, especialmente quando se consideram o sexo, a cor da pele e as regiões do Brasil. Isso indica a formação de possível base de apoio partidário que só poderá ser confirmada em 2010.

\subsection{Considerações finais}

A análise do comportamento eleitoral tem como tradição levar em consideração as características socioeconômicas dos eleitores. Desde os primeiros trabalhos que utilizaram dados agregados até os mais recentes, que recorrem a dados de survey, estes fatores têm merecido atenção especial dos pesquisadores. Isso não ocorre por acaso, uma vez que muitos identificaram relações importantes entre essas características e o voto, a ponto de encontramos nos trabalhos da escola sociológica a afirmação que as características socioeconômicas determinam aquele comportamento. No Brasil, não foram poucos os trabalhos inspirados nessa perspectiva que apontaram para conclusões semelhantes. Muitos ainda indicam que a escolaridade, indicativa de posição social, é central para entender como se comporta o eleitor.

O estudo que aqui fizemos mostra que, no caso brasileiro da disputa entre o PSDB e o PT nas eleições presidenciais, conhecer as características socioeconômicas dos eleitores não ajuda muito a predizer sua decisão política entre os dois partidos. No que diz respeito à escolaridade, o aspecto mais 
importante a ser destacado é que os eleitores menos escolarizados tendem a apoiar o partido do governo, enquanto que os mais escolarizados tendem a apoiar a oposição. Mesmo assim, na maioria dos modelos, a razão de chance entre os mais e os menos escolarizados não é significante. Ou seja, saber a escolaridade não informa nada a respeito do voto no PSDB ou no PT.

As características socioeconômicas mais importantes para distinguir os eleitores dos dois partidos no decorrer de todo o período foram a renda familiar, a cor da pele e a região do país. Contudo, as diferenças observadas entre os partidos, tomando tais características em consideração, são muito pequenas e, exceto em casos de disputa muito equilibrada, o que ainda não ocorreu entre PSDB e PT, não determinam qualquer resultado eleitoral. Apesar disso, os resultados das eleições de 2006 foram os que mais sofreram influências das características socioeconômicas e que mais polarizaram os eleitorados dos dois partidos. Resta saber se, à medida que incorporarmos outras variáveis ao modelo, tal polarização persiste.

Tendo examinado detidamente os efeitos exercidos pelas variáveis socioeconômicas nos modelos probabilísticos de voto no PT e no PSDB, nossa atenção agora se deslocará para outro conjunto de variáveis, classificadas aqui como de longo prazo, quais sejam os partidos e a ideologia. 


\section{Capítulo 2. Modelo partidário e ideológico de decisão de voto}

\subsection{Introdução}

No capítulo precedente, examinamos o impacto das condições demográficas e socioeconômicas na definição do voto entre PSDB e PT nas eleições presidenciais brasileiras de 1994 até 2006 e mostramos que tais condições não são importantes para a direção do voto dos eleitores brasileiros. Devemos agora voltar nossa atenção para outro conjunto de variáveis, também classificadas como de longo prazo, que são apontadas como relevantes para a compreensão do fenômeno que estamos estudando. O estudo do comportamento político e eleitoral nas democracias contemporâneas pede atenção sobre os partidos políticos e as ideologias. Essa exigência decorre do fato de que partidos e ideologias ocupam espaço central na luta pelo poder e na conquista do eleitorado que define quem alcança ou não as posições de comando dentro das nações.

As duas variáveis políticas - partidos e ideologia - têm sido objeto de estudo mais sistemático dos cientistas políticos desde que entraram em cena no mundo ocidental, principalmente a partir de meados do século XIX. Contudo, passaram a ganhar força e destaque nas análises do comportamento eleitoral empreendidas a partir do fim da II Guerra Mundial. Com efeito, é apenas depois de 1945 que partidos e ideologia começaram a se tornar importantes para a grande massa eleitoral que, gradualmente, vieram desempenhar papel de destaque na definição dos destinos políticos dos países democráticos.

A pesquisa do impacto exercido por partidos e ideologia no comportamento eleitoral deve necessariamente considerar dois pontos de vista, quais sejam: dos atores mais diretamente envolvidos nas disputas, os partidos e os políticos; e dos eleitores. As variáveis políticas adquirem conotações diferentes para cada qual desses diferentes atores. Para os primeiros, partidos e ideologia devem ser investigados tendo-se em vista, em especial, as estruturas partidárias e as alianças eleitorais que envolvem 
essas estruturas. Para os eleitores, partidos e ideologias funcionam mais como atalhos de informação a partir dos quais podem decidir em quem votar.

Neste capítulo, investigamos os papéis desempenhados por partidos e ideologias nas eleições presidenciais brasileiras, considerando-os do ponto de vista dos atalhos informacionais que podem estruturar as decisões políticas dos eleitores. Inicialmente, tratamos da literatura nacional e internacional sobre partidos e ideologias na decisão de voto; em seguida, à luz da teoria, expomos os processos que levaram PT e PSDB a liderar as disputas pela Presidência da República, traçando um contexto partidário e ideológico da disputa; por fim, analisamos os dados disponíveis sob a direção da teoria e dos fatos.

\subsection{Partidos e ideologias na literatura internacional sobre $o$ comportamento eleitoral}

Nos estudos sobre o comportamento eleitoral, partidos e ideologias ocupam lugar de destaque. Diversos autores já se dedicaram a essas variáveis. As primeiras investigações importantes sobre o comportamento eleitoral que utilizaram dados de pesquisa quantitativa já tomavam os partidos como elementos centrais para compreender o comportamento político.

Nos EUA, de acordo com os estudos da Escola de Colúmbia (cf. Berelson, Lazarsfeld \& McPhee, 1954, e Lazarsfeld, Berelson \& Gaudet, 1948), os partidários de democratas e republicanos não se diferenciavam apenas nas suas características socioeconômicas, como já vimos. Também exibiam diferenças notáveis no que diz respeito a posicionamentos frente às questões políticas der destaque no debate eleitoral. Os eleitores percebiam que os partidos posicionavam-se de forma desigual, assim como percebiam também as desigualdades nas posições dos candidatos. Na eleição presidencial de 1940, o Partido Democrata e seu candidato Franklin D. Roosevelt representavam o homem comum, o público, o não-isolacionismo, enquanto o Partido Republicano e seu candidato Wendell L. Willkie eram os representantes dos homens de negócio, dos negócios privados e do isolacionismo. Essa era a percepção da maioria do eleitorado, independentemente da filiação partidária.

Apesar das diferenças, os autores de Colúmbia ponderam que são poucos os eleitores absolutamente afinados com as posições de seus 
partidos e que existe grande dose de tolerância política da parte deles. Isso decorre também do comportamento dos dois partidos, uma vez que estes adotam as mesmas posições a respeito de várias questões. Por esse motivo, durante a campanha, os partidos tratam de mostrar os principais e mais fortes pontos de diferenciação com o adversário, bem como de esconder seus pontos fracos. Todavia, a posição dos eleitores frente aos partidos proporcionava um excelente prognóstico da direção que seu voto tomaria ou seja, os que se declaravam republicanos e os que se declaravam democratas tendiam fortemente a votar nos candidatos de seus partidos.

Os partidos políticos também desempenham papel importante na teoria econômica da democracia. Em seu modelo, Downs (1999) reconhece apenas três entidades que tomam decisões políticas: os partidos, os cidadãos individuais e os grupos de interesse corporativos. Para o autor, os partidos são equipes de homens que concordam com todas as suas metas e que buscam controlar o governo, obtendo cargos em eleições devidamente constituídas. O fato de haver metas partidárias com que todos os membros de um partido concordam está relacionado a uma idéia que é central no modelo de Downs. Trata-se do axioma do interesse pessoal, segundo o qual todos os indivíduos agem para obtenção de sua própria segurança e liberdade e pensam mais em si próprios que nos outros. Quando surge um choque entre a segurança e a liberdade própria e as de outrem, o homem pode sacrificar o interesse desse outro alguém em benefício do seu próprio. Assim, sempre que fala em um comportamento racional, Downs se refere a um comportamento racional dirigido principalmente a fins egoístas.

Dessa idéia deriva a concepção de motivação da ação partidária, que nasce apenas porque os membros querem obter renda, prestígio e poder. Assim, os políticos de Downs nunca buscam o poder como meio para executar políticas específicas: "Seu único objetivo é colher as recompensas de ocupar um cargo público per se. Eles tratam as políticas puramente como meios de atingir seus fins privados, que eles conseguem alcançar somente se forem eleitos" (Downs, 1999, p. 50).

Sobre esse ponto se assenta uma das hipóteses centrais de Downs: os partidos formulam políticas para ganhar as eleições e não ganham as 
eleições para formular políticas. Para ele, a análise de governo deve levar em conta os interesses privados dos que o dirigem, não apenas o objetivo formal dos partidos, que seria formular e executar políticas quando estão no poder. Isso leva o autor a afirmar que o objetivo primeiro dos membros de um partido é serem eleitos, que todas as suas ações visam à maximização dos votos e que as políticas constituem o meio para isso.

A tarefa de maximizar votos é complexa, uma vez que o governo deve descobrir qual é a relação entre aquilo que faz e como os cidadãos votam. Se o eleitor é racional, vota no partido que ele acredita que Ihe proporcionará mais benefícios do que qualquer outro. Os benefícios considerados são os obtidos a partir da atividade governamental, são definidos como utilidade. "Diante de diversas alternativas mutuamente exclusivas, um homem racional sempre escolhe aquela que Ihe traz maior utilidade, ceteris paribus; isto é, ele age para seu próprio e maior benefício" (Downs, 1999, p. 57).

No contexto dos EUA, foi Downs quem deu mais peso teórico ao papel da ideologia partidária na decisão de voto. Nos escritos da Escola de Colúmbia e, depois, na de Michigan, a ideologia aparece sem muita relação com o voto ou fica restrita a um pequeno grupo de eleitores mais sofisticados. A maior parcela do eleitorado, nesses casos, não é ideológica, é partidária.

Downs (1999, p. 57) define a ideologia como "uma imagem verbal da boa sociedade e dos principais meios de construir tal sociedade" e a trata como um meio para chegar ao poder. Para ele, a ideologia tem papel importante, tanto para os eleitores, como para os partidos. Para os primeiros, serviria como atalho de informação racional que os livraria do esforço de se manterem sempre informados sobre extensa gama de questões, uma vez que tenderiam a adotar alguma ideologia e a votar de acordo com esta. Para os partidos, ele pondera que não é possível separá-los da ideologia, porque sempre buscariam tomar aquela que acreditam atrair mais votos. Na visão de Downs, existe uma ampla variedade de ideologias à disposição dos partidos, tantas quanto mais heterogênea for a sociedade em que estiverem presentes e quanto mais inevitável for o conflito social. Se a isso for somada a incerteza, que faz com que não se saiba qual combinação ideológica é capaz de formar a maioria, surgiriam muitas opções ideológicas à disposição dos partidos. 
Embora a trate como meio de chegar ao poder, Downs considera que a ideologia deveria ser consistente, tanto internamente, como em relação às políticas concretas adotadas pelos partidos. Nessas condições, o autor afirma que a ideologia dos partidos deveria ser relativamente coerente e imóvel. $O$ que impõe o "relativamente" é que a sociedade é dinâmica e está em constante transformação, novas questões entram em cena, e as ideologias precisariam, de uma forma ou de outra, se adaptar a essas novidades. Normalmente, as ideologias partidárias estariam defasadas em relação ao que de fato acontece na sociedade, e sempre surgiriam, no interior dos partidos, conflitos entre a manutenção da pureza ideológica e a vitória nas eleições.

Downs adapta a noção de mercado espacial para a política. Reduzindo as questões políticas a uma escala esquerda e direita, seria possível avaliar a posição de eleitores e partidos. Existiriam diversas configurações ideológicas possíveis, e cada sociedade teria a sua, dependendo de fatores históricos, sociais, culturais, psicológicos e econômicos. Os eleitores poderiam estar concentrados no centro, nas duas extremidades, em uma das extremidades ou igualmente distribuídos em toda a escala — enfim, muitas configurações seriam possíveis. Dessa distribuição dos eleitores ao longo do contínuo esquerda-direita dependeria o número de partidos em uma dada democracia: quanto mais heterogênea, mais partidos.

O número de partidos depende da sociedade, mas também das regras do jogo. Se existem barreiras legais à criação de novos partidos e se o sistema eleitoral for majoritário, a tendência é o bipartidarismo; se existem poucas barreiras para o surgimento de novos partidos e se o sistema eleitoral for proporcional, a tendência é o pluripartidarismo. No entanto, Downs pondera que o sistema eleitoral pode ser tanto a causa, como o resultado da distribuição dos eleitores ao longo daquela escala.

Fica claro, na análise downsiana, que a distribuição dos eleitores ao longo da escala e o sistema eleitoral são fatores centrais na determinação de quantos partidos uma democracia deve ter. Em sistemas multipartidários, os partidos se acomodariam até estabelecerem entre si uma distância ideológica equivalente, e existiria um empenho da parte dos partidos em se distinguirem 
ideologicamente. Nos sistemas bipartidários, os partidos tenderiam a se aproximar e a se parecer ideologicamente. Para o autor, é mais racional o voto ideológico em sistemas multipartidários, porque nesses casos fica clara qual é a posição de cada partido; para os eleitores em sistemas bipartidários, a distinção é mais difícil e isto pode levá-los a tomar decisões com base em outras questões, como personalidade do candidato, tradição familiar, lealdade a amigos e políticos. Outro aspecto relevante com relação a sistemas multipartidários é que habitualmente conduzem a governos de coalizão. Nesses casos, a ideologia, que seria marcada na plataforma política dos partidos, ficaria esmaecida.

A situação se complicaria para o eleitor votar racionalmente tendo como base a ideologia quando são levados em conta governos de coalizão. Em sistemas pluripartidários, pode ocorrer que nenhum partido tenha a maioria e seja obrigado a compor com outro partido para obtê-la. A eventualidade da realização de coalizões governamentais torna ainda mais difícil a tarefa de selecionar ideologicamente de forma racional um partido ou candidato, porque as combinações possíveis são numerosas e, muitas vezes, não fica claro, para o eleitor, o resultado do seu voto. Custa mais caro e demanda mais tempo estar também informado sobre como votarão os demais eleitores e, a partir daí, calcular o voto.

Há uma pressão contínua para que os eleitores sejam irracionais, isto é, parem de considerar as eleições como mecanismos diretos de seleção de governo. Essa pressão é especialmente forte se o número de coalizões prováveis for grande e se suas variações de políticas forem extensas. Assim, a complexidade de tentar descobrir como construir o governo mais favorável possível pode levar cada eleitor a simplesmente apoiar seu partido favorito e deixar a seleção do governo para a legislatura (Downs, 1999, p. 174).

Outro trabalho importante que concentra foco no papel dos partidos no comportamento eleitoral e na decisão de voto em eleições presidenciais é o The American Voter (Campbell, Converse, Miller \& Stokes, 1960). Os autores, da Escola de Michigan, foram mais longe no tratamento da identificação partidária como variável principal na decisão política. Afinal, argumentam eles, nos regimes democráticos, os elementos mais duradouros costumam ser os partidos políticos. Tal durabilidade faz com que as imagens que os eleitores 
fazem dos partidos estejam relacionadas ao voto. Gostar ou não gostar de um partido e a identificação partidária seriam variáveis distintas que tentam medir o mesmo fenômeno político; seriam indicadores de um partidarismo do qual nenhuma decisão eleitoral seria alheia.

"Partidarismo" não quer dizer que os eleitores participam formalmente dos partidos ou que sempre votam na mesma agremiação. A identificação psicológica a um partido é tratada pelos autores como orientação individual afetiva com relação a um grupo ou objeto de seu ambiente. Os partidos políticos serviriam como grupos, frente aos quais o indivíduo poderia desenvolver uma identificação positiva ou negativa, com algum grau de intensidade. Em seu trabalho, os autores mediram a identificação partidária a partir da opinião dos entrevistados - ou seja, da autoclassificação - e, dessa forma, criaram um contínuo de partidarismo, desde os fortemente democratas até os fortemente republicanos.

Os autores observam também que os partidos têm uma história que se combina com os eventos mais recentes em que estiveram envolvidos. 0 eleitor individual, em certa medida, avaliaria a trajetória do partido e visualizaria as transformações do ambiente político. Assim, faria uma avaliação mais acurada da disputa eleitoral. Vale dizer que, de algum modo, os eleitores saberiam das diferenças e as semelhanças entre os partidos que disputam as eleições, em particular as presidenciais. Saberiam, ainda que vagamente, o que esses partidos fizeram no governo e na oposição e seriam capazes de desenvolver algum tipo de leitura partidária dos candidatos. Esse misto de imagens e informações - ao mesmo tempo polarizadas e semelhantes, tênues e marcantes - influiria nas chances que um eleitor teria de escolher um ou outro candidato na disputa presidencial.

Com relação à ideologia, os autores da Escola de Michigan definem o eleitor ideológico como aquele que estabelece relações lógicas entre questões específicas da política pública e princípios gerais abstratos e que vota de acordo com essa estruturação. Nessa perspectiva, mostram que a ideologia não está presente na cabeça da maioria dos eleitores norteamericanos e que o contínuo liberal-conservador, tão caro aos pesquisadores e analistas políticos dos EUA, não é uma noção comum à qual a maioria do 
eleitorado recorreria para decidir seu voto. As pesquisas realizadas pelos autores apontaram a existência de uma proporção muito baixa de eleitores que estruturam seus votos a partir de considerações ideológicas.

Phillip E. Converse, um dos co-autores de The American Voter, procurou investigar mais a fundo a estrutura ideológica dos eleitores e reforçou as conclusões que seus colegas e ele já haviam chegado (cf. Converse, 1964). Ele procura mostrar que existiria forte associação entre a posse de um sistema de crença ideologicamente estruturado e o nível de educação formal. Dessa forma, só os eleitores mais escolarizados teriam comportamento político-eleitoral ideologicamente estruturado. A grande massa eleitoral, pouco escolarizada, adotaria um sistema de crenças desestruturado e desligado da ideologia.

Essa visão do eleitor dos EUA e do eleitorado em geral como destituído de estruturação ideológica foi alterada a partir do trabalho The Changing American Voter (Nie et al., 1981), no qual os autores procuram mostrar que o processo de radicalização política por que passou os EUA nos anos 60 levou ao aumento da estruturação ideológica. Para eles, questões políticas, como a Guerra do Vietnam e os conflitos raciais, e candidatos mais claramente ideológicos, como o democrata George McGovern e o republicano Barry Goldwater, levaram a considerável aumento no nível de polarização ideológica do eleitorado, que, em comparação com o que se observava na década anterior, praticamente dobrou. Para os autores, isso se deveu a um cenário político mais ideológico, que levou os eleitores a acompanhar essa transformação.

Um trabalho importante apontou para a decadência da centralidade dos partidos dos EUA na definição do voto presidencial. Trata-se de Retrospective Voting in American National Elections, de Morris Fiorina (publicado em 1981). Seu argumento é que a identificação partidária, a qual normalmente surge no processo de socialização do indivíduo, é importante no comportamento eleitoral. Não obstante, tão ou mais importante do que essa identificação, a avaliação que o eleitor faz da experiência que acumula ao longo de sucessivas eleições influi decisivamente na decisão política. Isso ocorre, segundo o autor, porque os cidadãos acompanhariam as promessas 
dos candidatos e as realizações dos governos ao longo do tempo, condensando essas informações em um julgamento sumário que Fiorina designa por identificação partidária. Em outras palavras, a identificação partidária não seria algo estável e imutável; seria apenas um atalho de informação que o eleitor utiliza para avaliar as promessas eleitorais e tomar sua decisão de voto. Assim, sua teoria consegue dar conta tanto da estabilidade, como da mudança, uma vez que a identificação partidária seria o resultado da interação entre uma socialização política prévia, geralmente mais estável, e a avaliação que se faz dos acontecimentos políticos, na medida em que se passa a acumular mais experiência.

Com base nesse argumento, Fiorina defende a idéia de que, se os partidos e os eleitores se posicionam da mesma forma ao longo do tempo de acordo com suas posições socioeconômicas, então deveria se esperar um reforço da identidade partidária. Contudo, se os partidos são inconsistentes ao longo do tempo, adotando posições diversas a cada eleição, se existe uma mobilidade social ponderável e novas questões políticas aparecem no debate público, então a identidade partidária também deveria mudar ou pelo menos flutuar. Seguramente, aponta o autor, a identidade partidária não inclui uma ideologia elaborada nem uma estruturação política em torno de todas ou da maioria das questões políticas relevantes, mas está relacionada ao dia-adia e à experiência dos eleitores.

O estudo The New American Voter (Miller \& Shanks, 1996) faz uma releitura da disputa eleitoral nos EUA a partir dos argumentos das escolas mencionadas e reafirma a importância dos partidos na decisão de voto. Para estes autores, a identificação partidária é uma atitude política durável, de longo prazo, responsável por moldar vasta gama de valores e percepções. Não negam que, à medida que as eleições se sucedem, fica mais claro que aumenta o peso das forças de curto prazo, contrabalançando a identificação partidária. Mas, para os autores, a identificação partidária, se não explica totalmente, pelo menos esclarece boa parte dos resultados eleitorais.

No cenário internacional, mais recentemente, analistas do comportamento eleitoral passaram a reposicionar os partidos políticos nos modelos que construíam (cf. Dalton \& Wattenberg, 2000, Dalton \& Wattenberg, 
1993, e Dalton, McAllister \& Wattenberg, 2003). Em boa parte das democracias ocidentais, enfraquece a identificação partidária. Se os estudos citados mais atrás, especialmente os das décadas de 40 a 60, mostravam que a identificação partidária era estável e central para a definição do voto nas eleições presidenciais, a partir dos anos 70 novos trabalhos apontam e apresentam evidências do declínio da influência exercida pelos partidos sobre os eleitores. Novos dados empíricos indicam considerável declínio nas taxas de identificação partidária e de aumento no voto dividido, ou seja, o voto em candidatos de partidos diferentes para os diferentes cargos em disputa, nos EUA, na Grã-Bretanha, na Itália, na Alemanha, isto é, em quase todos os países democráticos ocidentais com regimes estáveis.

Essa queda nos índices de identificação partidária decorre de questões que surgiram na agenda dos governos e deslocaram a atenção do eleitor para aspectos não diretamente relacionados aos partidos políticos. Isso não significa dizer que os partidos não busquem se posicionar frente às novidades que adentram a arena pública. Se uma dada posição puder ser utilizada para ganhar mais votos, certamente tomarão a decisão de adotá-la. Os adversários talvez ajam da mesma forma, o que torna a novidade e a atitude partidária menos influentes no resultado eleitoral.

A revisão que fizemos mostra que, na literatura internacional, o papel exercido por partidos e ideologia na decisão do voto é importante, mas perdeu muito de sua capacidade explicativa com o passar dos anos, especialmente em virtude do enfraquecimento do embate ideológico e do movimento centrípeto observado nos sistemas partidários eleitorais de diversas democracias ocidentais. Os partidos de esquerda e de direita aproximaram muito suas plataformas eleitorais, e essas dimensões já não fazem tanto sentido para o cidadão. Além disso, os partidos deixaram de ser os veículos mais importantes na disseminação das mensagens políticoeleitorais: o avanço dos meios de comunicação de massa, em grande medida, promoveu a destituição do partido do papel de principal responsável pela circulação das informações políticas. 


\subsection{Os partidos na decisão do voto no Brasil}

Nos regimes democráticos, os partidos políticos são organizações que atuam em duas arenas distintas e interligadas. Estão presentes na arena decisória, participando ativamente na formulação e na implementação de políticas públicas; esse papel é conquistado e renovado na arena eleitoral pelo voto popular. A participação na tomada de decisões e nas disputas eleitorais faz com que os partidos possam ser vistos como elementos de ligação entre a sociedade e o Estado, como os responsáveis pelas políticas e controláveis pelos eleitores. A realidade brasileira, contudo, tem mostrado que a atuação partidária está algo distante dessa visão.

Os estudos que focalizam os partidos brasileiros na arena decisória têm apontado para uma direção algo positiva. Sobre a atuação no Poder Legislativo, até meados dos anos 90, autores como Amorim Neto (1994) e Mainwaring (1997) afirmavam que os partidos eram indiferenciados e indisciplinados e o que valia era a vontade do parlamentar individual, o que gerava sérias dificuldades à governabilidade. No mesmo momento, outros autores, como Figueiredo \& Limongi (1999), Kinzo (1993) e Rodrigues (2002), produziam pesquisas que passaram a mostrar que os partidos, no Parlamento, adotam posições políticas e ideológicas distintas. Ainda que a diferença entre um partido e outro possa ser tênue, no conjunto da representação existem diferenças marcantes entre os dois. Afinal, o Parlamento é muito permeável à representação de minorias, o que sempre acarreta algum tipo de polarização ideológica.

Quanto aos partidos no Poder Executivo, o trabalho de Meneghello (1998) analisa a formação dos gabinetes ministeriais e mostra que os partidos políticos são organizações capazes de integrar coalizões governamentais ideologicamente coerentes e de entabular negociações de alto nível com o Parlamento e outros participantes da sociedade organizada. Os governos presidencialistas, como regra, são livres para nomear seus ministros sem qualquer interferência externa; no Brasil, contudo, os ministérios são constituídos a partir da necessidade de formação de maiorias parlamentares capazes de dar sustentação política ao governo no Congresso Nacional. Isso mostra que os partidos políticos necessariamente são parceiros do governo, tanto no Executivo, 
como no Legislativo. Essa parceria normalmente rende frutos para os partidos participantes da coalizão, uma vez que obtêm vantagens competitivas oriundas do controle de parte do aparato governamental, e isso fortalece a organização partidária a partir de bases nacionais.

Se na arena decisória os partidos políticos tendem a ser vistos como organizações centrais e diferenciadas, na eleitoral a visão é outra. As principais tarefas de um partido político nessa arena consistem em

estruturar a disputa eleitoral, ou seja, definir e diferenciar as opções a serem oferecidas ao eleitor, facilitando o ato de votar e possibilitando a construção de identidades políticas; e mobilizar o eleitorado, isto é, incentivar o eleitor a ir às urnas e a votar em uma das opções oferecidas, opções que se constituem como agregações de preferências, ou seja, representação de interesses (Kinzo, 2004, p. 25).

De acordo com essa visão, vamos procurar mostrar que os partidos políticos brasileiros não estão conseguindo desempenhar essas tarefas de forma satisfatória. As evidências para isso serão extraídas da análise da bibliografia e dos dados de pesquisa utilizados nesta tese.

A bibliografia brasileira sobre os partidos na arena eleitoral trata basicamente de dois diferentes tipos de dados. De um lado, existem pesquisas que privilegiam a utilização de dados eleitorais agregados e recorrem a indicadores como a fragmentação partidária e a volatilidade eleitoral. De outro lado, há trabalhos que utilizam apenas dados de pesquisas de opinião por amostragem e tratam principalmente dos níveis de partidarismo em distintas operacionalizações desse conceito. Também ocorrem autores que buscam combinar os dois tipos de dados, o que será feito aqui, com maior ênfase no segundo tipo.

\subsubsection{Dados agregados na análise dos partidos na arena eleitoral}

O Brasil possui um sistema eleitoral complexo. Aqui são realizadas eleições para três níveis de governo - municipal, estadual e federal - e para escolher os representantes dos Poderes Legislativo e Executivo, cada qual com sistemas diferentes. Para os cargos legislativos, o sistema é o de 
representação proporcional com lista aberta, e a disputa acontece em amplas circunscrições eleitorais, entre diversos partidos e coligações de partidos diferentes, o que gera grande quantidade de candidatos. Para a eleição de senadores, o sistema é o majoritário de turno único, e a magnitude é igual a um ou dois. Ainda que os partidos detenham o monopólio na apresentação de postulantes a cargos eletivos, as campanhas em geral são personalizadas, na base do "cada um por si", e bancadas pelos próprios candidatos ou por grupos de interesse a eles vinculados. Dessa forma, é difícil identificar quem os representantes representam, especialmente quando se considera que os padrões de votação dos candidatos são mais dispersos que concentrados, como mostram Kinzo, Martins Jr. \& Borin (2003 e 2004).

Para os cargos executivos, o sistema é o majoritário em turno único, para a eleição de prefeitos em municípios até 200.000 eleitores, ou em dois turnos, para os prefeitos de cidades maiores, de governadores dos estados e do Distrito Federal, e para a Presidência da República. Nesses casos, com magnitudes sempre iguais a um, o número de candidatos é muito menor, o que torna os partidos elementos mais visíveis. Quase sempre, os mais importantes candidatos a cargos no Executivo são indivíduos historicamente ligados aos partidos aos quais pertencem. Contudo, assim como nas eleições para o Legislativo, naquelas para o Executivo são formadas alianças partidárias amplas, que obscurecem as diferenças partidárias. Dantas mostra que, nas eleições municipais de 2000 e 2004, respectivamente, o PT e o PSDB, principais adversários nas eleições presidenciais, celebraram nada menos que 451 e 901 alianças eleitorais. ${ }^{1}$

Desde a publicação do clássico trabalho de Duverger (1980), sabe-se que diferentes sistemas eleitorais geram diferentes incentivos à fragmentação. Sistemas majoritários tendem ao bipartidarismo e sistemas proporcionais, ao multipartidarismo. O número esperado de partidos em uma disputa é igual à magnitude do distrito mais um $(M+1)$, o que, em nosso caso faz, com que seja teoricamente esperada a existência de até 95 partidos políticos, considerando-se a maior magnitude observada, que é a eleição para a

${ }^{1}$ Esse dado consta da futura tese de doutorado do autor, que tem título provisório de Coligações em eleições majoritárias em municípios: a lógica do alinhamento dos partidos. 
Assembléia Legislativa paulista. A excessiva fragmentação possível só não ocorre porque a realização das eleições para o Legislativo e o Executivo é simultânea, o que gera certos controles à excessiva fragmentação.

O resultado final dessa fórmula complexa em termos de fragmentação partidária é que, a despeito da realização de quatro eleições casadas desde 1994, o sistema partidário brasileiro continua um dos mais fragmentados do mundo. O resultado esperado, caso os partidos cumprissem suas tarefas, seria a redução da fragmentação no período, mas isso não foi observado. 0 trabalho de Braga (2006) apresenta dados relativos ao número de partidos efetivos, ${ }^{2}$ nas eleições para presidente, governador e deputado federal entre 1994 e 2002. A média dos valores observados nos estados, nessas disputas, mostra um aumento do indicador para os três cargos. Segundo dados analisados por Kinzo (2004), o número de partidos efetivos na Câmara dos Deputados oscilou entre 9 e 8,5 no período de 1990 até 2002, concluindo-se que "o sistema partidário continua tão fragmentado como no início da década de 90" (Kinzo, 2004, p. 31). Na eleição de 2006, diminuiu o número de partidos efetivos nas eleições majoritárias realizadas nos estados. Talvez essa menor fragmentação seja decorrente da reeleição, uma vez que essa tendência já havia sido observada em 1998.

Tabela 2: Partidos e candidatos efetivos em eleições majoritárias

\begin{tabular}{|l|c|c|c|c|}
\hline Partidos efetivos na disputa para presidente nos estados & $\mathbf{1 9 9 4}$ & $\mathbf{1 9 9 8}$ & $\mathbf{2 0 0 2}$ & $\mathbf{2 0 0 6}$ \\
\hline \hline até 2 & 2 & 1 & 0 & 7 \\
\hline entre 2 e 2,5 & 16 & 11 & 0 & 17 \\
\hline entre 2,5 e 3 & 6 & 12 & 10 & 3 \\
\hline mais de 3 & 3 & 2 & 17 & 0 \\
\hline Candidatos efetivos a governador & $\mathbf{1 9 9 4}$ & $\mathbf{1 9 9 8}$ & $\mathbf{2 0 0 2}$ & $\mathbf{2 0 0 6}$ \\
\hline até 2 & 2 & 3 & 1 & 4 \\
\hline entre 2 e 2,5 & 9 & 13 & 10 & 14 \\
\hline entre 2,5 e 3 & 9 & 8 & 8 & 6 \\
\hline mais de 3 & 7 & 3 & 8 & 3 \\
\hline
\end{tabular}

Fonte: TSE e Nicolau (1998).

Outros importantes indicadores, criados a partir de dados eleitorais agregados, para aferir qualitativamente como os partidos estão cumprindo suas principais tarefas, são o índice de volatilidade partidária proposto por

\footnotetext{
${ }^{2}$ Medido pelo índice de fragmentação (N) de Laakso \& Taagepera (1979).
} 
Pedersen (cf. Pedersen, 1980 e 1990) e o índice de volatilidade ideológica de Bartolini \& Mair (1990).

O trabalho coletivo organizado por Lima Jr. (org., 1997) foi um dos pioneiros na análise desse indicador para apontar uma tendência de queda na volatilidade total, entre e intrablocos ideológicos, de 1982 a 1994. O autor observa que

a volatilidade entre os blocos de partidos é sempre inferior à volatilidade dentro dos blocos partidários. Esse fato mostra que a probabilidade de segmentos do eleitorado transferirem seu voto de um partido para outro é maior quando os partidos se situam no mesmo bloco ideológico do que quando pertencem a blocos diferentes (Lima Jr., org., 1997, p. 308).

Não fosse apenas pela elevada volatilidade partidária, a volatilidade ideológica revela a fragilidade dos partidos, que não conseguem reter sequer os eleitores situados no mesmo campo ideológico que procuram ocupar.

Os trabalhos de Peres (2000 e 2002) indicam que os padrões de volatilidade no Brasil ainda estão acima dos índices dos países europeus e da América Latina. Não obstante, ao estudar os dados de volatilidade no caso dos estados brasileiros ao longo tempo, ele afirma que "mostram uma queda significativa no grau de instabilidade eleitoral, com uma dinâmica diferenciada quando comparamos estados e regiões entre si" (Peres, 2002, p. 40). O autor chama atenção para o fato de que, no Brasil, a volatilidade partidária é mais alta que a volatilidade ideológica e conclui que

a coexistência de volatilidade eleitoral partidária relativamente elevada com volatilidade eleitoral ideológica relativamente baixa significa que o sistema partidário estrutura as preferências em termos ideológicos e que existe uma competição elevada entre os partidos que pertencem ao mesmo bloco (Peres, 2002, p. 42).

Tal conclusão parece contraditória: afinal, como afirmar que o sistema partidário estrutura as preferências em termos ideológicos, se os partidos não conseguem manter suas bases de apoio nesses mesmos termos? 
Apesar do diagnóstico de queda desse indicador, o trabalho de Nicolau (1998) expõe dados que indicam volatilidade eleitoral média superior a 30\% durante o período de 1982 e 1998, taxa mais elevada que a observada em qualquer democracia consolidada ou emergente. Outra pesquisadora que analisou detalhadamente o indicador foi Braga (2006). Os dados que mostra revelam, assim como os autores lembrados, uma elevada volatilidade eleitoral de 1990 até 2002. Além disso, não é possível identificar um padrão declinante claro, sendo mais correto classificá-lo como flutuante.

Em suma, a análise dos dados agregados das eleições brasileiras, especialmente quando se consideram os resultados ao nível parlamentar, mostram que o sistema partidário eleitoral continua fragmentado e volátil. Esses são aspectos importantes, que indicam que os partidos políticos não conseguiram estabelecer um padrão definido de apoio. Ao nível do Executivo, a situação parece ser um pouco diferente, uma vez que a disputa é mais concentrada e os partidos, apesar das alianças, são mais visíveis. Tanto é assim que PSDB e PT dominam a eleição presidencial desde 1994, apesar da alta fragmentação e volatilidade. Talvez a resposta para isso possa ser encontrada ao nível do eleitor, não ao nível agregado.

\subsubsection{Dados de pesquisa de opinião na análise dos partidos na arena} eleitoral

O interesse central aqui é entender os efeitos que as opiniões dos eleitores em relação aos partidos políticos exercem sobre o comportamento eleitoral - em especial no que diz respeito à disputa entre PSDB e PT na eleição presidencial - e recai sobre as pesquisas nacionais realizadas entre 1994 e 2006. Para compreender melhor o papel desempenhado pelo partidarismo na decisão de voto no Brasil, cabe abordar, ainda que brevemente, os trabalhos que trataram das eleições realizadas nos períodos do pluripartidarismo (1945 a 1965) e do bipartidarismo (1965 a 1979).

Uma das obras mais importantes para a compreensão do sistema partidário entre 1945 e 1964 é a de Lavareda (1991). Para este autor, o registro constante de crescimento dos níveis de identificação partidária e de sua congruência com as opções eleitorais são indicadores importantes do 
grau de consolidação do vínculo entre os partidos e a sociedade no período. Seu trabalho apresenta uma extensa análise sobre a identidade partidária, cujas conclusões mais importantes indicam uma taxa média da ordem de 64\% em sete grandes capitais no ano de 1964 e um padrão crescente de identificação em cidades como Rio de Janeiro, Belo Horizonte e Porto Alegre. Mais do que isso, a autor mostra elevada sintonia entre a identificação partidária e o voto nas eleições presidenciais de 1955 e 1960 (cf. Lavareda, 1991, p. 161). Em poucas palavras, o sistema estaria em franco processo de consolidação, porque a identificação partidária entre os eleitores aumentava progressivamente, e cada vez mais isso fazia sentido para as opções eleitorais que tomavam.

$\mathrm{Na}$ fase do bipartidarismo, uma série de trabalhos importantes já citados (Lamounier \& Cardoso, 1978, Lamounier, 1980, e Reis, org., 1978) apontou que parcelas significativas do eleitorado apresentavam identificação partidária, até mesmo ao se considerar diferentes contextos socioeconômicos, como já vimos. Essas identificações eram excelentes instrumentos de predição do voto, uma vez que os eleitores se identificavam com um dos dois partidos em disputa e votavam de acordo com essa identificação. Não obstante, a maioria dos eleitores, especialmente os de nível educacional mais baixo, apresentava identificação partidária difusa, baseada especialmente em opiniões que contrapunham governo e oposição ou, ainda, elite e povo, desvinculadas do debate político institucional, ou seja, sem conteúdo propriamente partidário.

A ausência de partidos que emprestassem algum conteúdo à disputa política levou Santos (1978) a salientar que a identificação partidária observada no período do bipartidarismo imposto pelos militares em 1965 não poderia ser comparada ao apoio estável a um partido, tal como encontrado em outros países, em especial nos EUA, na mesma época. Para o autor, essa identificação não compõe uma imagem correta da realidade dos eleitores brasileiros. Diferentemente do que ocorre nos EUA, no Brasil a adesão a uma das siglas, MDB ou Arena, expressaria apenas um sentimento genérico de oposição ou adesão ao regime militar. O apoio ao MDB, em 
particular, seria decorrente da disposição do brasileiro para votar sempre na oposição, seja qual for o governo.

Durante o período do regime militar e após a abertura política, Lamounier (1975; 1978; org., 1980; e 1989, entre outros) publicou diversos trabalhos em que mostrava a existência de uma clara relação entre o eleitorado e os partidos, que se manteve até mesmo após a abertura política e a introdução de novo sistema partidário. Segundo este autor, para a maioria dos eleitores, ao menos nas grandes cidades, forjou-se uma relação entre partidos e cidadãos que, mesmo não tendo a mesma força e o mesmo significado que em outros países, estava longe de ser destituída, seja de força, seja de significado. Mesmo quando identifica tal relação, Lamounier segue trilha idêntica à de Reis e Santos em sua visão pessimista das possibilidades de consolidação de um sistema partidário no qual os partidos se diferenciassem programática ou ideologicamente. Já durante o regime democrático e com certeza influenciados pela campanha e pelo governo de Fernando Collor, Baquero (1994), Meneghello (1994) e Singer (1990) mantinham essa visão quanto ao insucesso da construção de identidades partidárias e indicavam uma tendência ao personalismo e ao populismo, aspectos que serão examinados no próximo capítulo.

As primeiras análises sobre a identificação partidária no atual sistema político, até meados dos anos 90, são precárias para medir o impacto dos partidos sobre o eleitorado, uma vez que o sistema ainda estava em formação. Ainda assim, são importantes, porque revelam o baixo nível de identificação partidária que marcou o início da nova experiência democrática brasileira como o trabalho de Kinzo (1992), que mostra a existência apenas 23\% de eleitores identificados com os partidos em Presidente Prudente, na eleição presidencial de 1989, e o de Meneghello (1995), que relata uma tendência declinante na identificação partidária entre 1989 e 1994.

Já no século XXI, Carreirão \& Kinzo (2004) utilizam dados de pesquisas do Datafolha para analisar a preferência partidária no Brasil no período entre 1989 e 2002. Nesse intervalo de tempo, a taxa de identificação partidária variou entre $41 \%$ e $54 \%$ do eleitorado nacional, com média de $46 \%$. A análise dos dados feita pelos autores mostra que não existe uma tendência de crescimento das identificações, o que deveria se esperar com a 
continuidade da experiência democrática. O que ocorre são oscilações negativas e positivas que não configuram qualquer tendência. Naquele período, apenas dois partidos, o PMDB e o PT, apresentam taxas de identificação superiores a 10\%, em média 14\%, sendo que o primeiro declina e o segundo ascende. Os autores indicam que existem influências importantes sobre a identificação partidária decorrentes das conjunturas eleitorais; assim, as preferências pelo Partido da Renovação Nacional (PRN) aumentam e diminuem junto com o prestígio de Fernando Collor, as preferências pelo PSDB crescem junto com Fernando Henrique em 1994, assim como ocorre com as preferências pelo PT e pelo Partido da Frente Liberal (PFL) em 2002, em acordo com o crescimento da candidatura de Lula e da pré-candidatura de Roseana Sarney. De qualquer forma, os índices de identificação partidária ficam sempre muito abaixo dos índices de intenção de voto dos candidatos. "Fora do período eleitoral, as variações ao longo do tempo são lentas, refletindo talvez avaliações dos eleitores em relação a práticas partidárias e/ou ações dos principais líderes partidários nos diversos níveis da federação" (Carreirão \& Kinzo, 2004, p. 147). Ainda que as identificações não sejam altas, são estáveis ao longo do tempo.

Em outro artigo, Kinzo (2005) examina dados de pesquisa sobre os partidos, realizada em 2002, junto ao eleitorado da Grande São Paulo, que revelam baixo nível de fixidez dos partidos políticos, dos quais o PT e o PMDB parecem ser as exceções, uma vez que são os únicos conhecidos por mais de $50 \%$ dos eleitores. Além disso, a proporção de entrevistados que errou ao vincular políticos tradicionais, como Antonio Carlos Magalhães, Leonel Brizola e José Dirceu, entre outros, aos partidos variou entre $76 \%$ e 97\%, revelando-se por outro ângulo a fragilidade dos laços partidários.

O fato de o nível das identificações partidárias ter se mantido praticamente estável durante todo o período da disputa entre PSDB e PT demonstra que os partidos têm dificuldades em fixar sua imagem junto ao eleitorado. Outra maneira de observar a aderência dos partidos no eleitorado é estudar a relação entre identificação partidária e voto. Diversos analistas dentre os quais Almeida (2006), Carreirão \& Barbetta (2004), Carreirão \& Kinzo (2004), Castro (1994), Kinzo (1992) e Singer (2000) — já observaram 
que medidas de partidarismo (que abordaram de variadas formas), como identificação, preferência, simpatia, rejeição, gostar ou não do partido, estão significativamente associadas ao voto.

O artigo de Kinzo (1992) e a tese de Castro (1994) apresentam um quadro ainda matizado, mas indicam uma correlação entre preferência partidária e voto. Os trabalhos seguintes, Singer (2000) e Carreirão \& Kinzo (2004), desenvolvem análises das relações entre intenção de voto e preferência partidária que consideram os campos ideológicos. Essa abordagem revela forte influência na decisão de voto, com os eleitores identificados com partidos de esquerda votando majoritariamente em candidatos de esquerda, o mesmo ocorrendo com os eleitores de centro, que votam em candidatos de centro, e com os de direita, que votam em candidatos de direita. Essas correlações são feitas a partir do agrupamento dos partidos e dos candidatos em campos ideológicos e não mostram se o eleitor identificado com algum partido vota no candidato do mesmo partido; além disso, consideram apenas os eleitores que no momento da pesquisa tinham simultaneamente alguma preferência por partido e por candidato presidencial, eleitores que em geral representam menos de $50 \%$ do eleitorado.

Carreirão \& Kinzo (2004) avançam para além da simples análise por campo ideológico e distinguem entre os eleitores: os que não possuem preferência partidária (cerca de 60\% do eleitorado entre 1989 e 2002); os que possuem preferência e votam no candidato do partido (22\%); e os que possuem preferência e votam ou em candidato de outro partido, ou em branco, ou nulo, ou estavam indecisos (16\%). Sob esse ponto de vista, na melhor das hipóteses, existiriam apenas 30\% de eleitores para quem a preferência partidária poderia ter influência sobre o voto nas quatro eleições consideradas. Só isso já tornaria a identificação partidária um instrumento pouco confiável de predição do voto.

Os autores também consideram a hipótese de que a rejeição tenha algum significado na decisão de voto. No total, segundo dados de pesquisa da Fundação Perseu Abramo, 10\% dos eleitores não têm preferência, mas rejeitam algum partido. Nesses casos, quase a totalidade dos eleitores não vota no partido rejeitado. Isso faz supor que a rejeição tenha realmente um 
significado na decisão de voto. De maneira geral, os autores indicam que $58 \%$ dos eleitores não são influenciados pelos partidos políticos, enquanto que os demais 42\%, percentual nada desprezível, são influenciados, seja pela preferência, seja pela rejeição partidária.

O trabalho de Carreirão \& Barbetta (2004) sobre a eleição presidencial de 2002 propôs uma forma alternativa de medir e avaliar os efeitos exercidos pelos partidos na decisão de voto. Tendo como universo de pesquisa os eleitores da Grande São Paulo, os autores adotam a análise de regressão logística para testar simultaneamente um conjunto amplo de hipóteses presentes na literatura, especialmente aquelas referentes às características socioeconômicas, às inclinações e aos sentimentos partidários, combinando preferência, simpatia e rejeição aos partidos, à identidade ideológica e às avaliações de governo e candidatos.

As conclusões dos autores a partir dos modelos de voto de cada candidato revelaram, entre outros aspectos, que os sentimentos partidários foram especialmente relevantes para determinar as chances de voto, especialmente no caso do PT. Para o PSDB, o modelo envolveu mais variáveis - inclusive socioeconômicas, como escolaridade e renda - e explicou menos o comportamento com relação ao partido. Para ambos os partidos, os resultados também indicaram a importância das avaliações de governo e dos candidatos na direção do voto. Mesmo considerando que um amplo conjunto de variáveis tenha sido significante nos modelos dos principais candidatos, fica muito clara a aderência do voto entre os eleitores que têm sentimentos partidários.

Os dados do Estudo Eleitoral Brasileiro (Eseb), colhidos de uma amostra nacional de eleitores em 2002, referentes à eleição presidencial daquele ano, foram estudados por Almeida (2006). O autor, cujo principal interesse é explicar a vitória de Lula naquela eleição, utiliza análises estatísticas multivariadas para entender a vantagem de Lula sobre seus adversários e para identificar os fatores mais importantes na previsão do comportamento do eleitor em relação a sua candidatura; no total, arrola as 16 variáveis que mais influenciaram na vantagem de Lula sobre Serra no primeiro turno do pleito, especialmente as avaliações das características 
pessoais, das posições frente aos temas da política pública e do governo e a ideologia. Apontam-se ainda os 14 fatores que mais ajudam a prever 0 comportamento do eleitor, dos quais os três mais importantes são considerar o candidato confiável, gostar do PT e considerar que o candidato tem bom plano de governo (Almeida, 2006, p. 268-269). Nesse modelo, a avaliação do governo Fernando Henrique Cardoso foi a $11^{\mathrm{a}}$ na lista das mais importantes para o voto no PT.

Em suma, os pesquisadores que investigaram o papel do partidarismo na decisão do voto mostram a existência de patamares estáveis em torno de $45 \%$ de eleitores com identidade partidária, além de parcelas mais expressivas que não se identificam com partidos, mas que têm simpatia ou rejeição ou simplesmente os avaliam de modo positivo ou negativo. Além disso, ficou evidenciado também que os eleitores com opiniões sobre os partidos tendem a considerá-las no momento do voto.

Retomando o que foi dito sobre as tarefas que o partido deve desempenhar na arena eleitoral, vimos que, quanto à análise dos dados eleitorais agregados a partir dos indicadores de fragmentação partidária e volatilidade eleitoral, a situação parece muito distante do satisfatório, especialmente quando consideramos as eleições proporcionais. Com relação aos trabalhos que baseiam suas análises em dados de pesquisa de opinião, ainda não está suficientemente claro quais foram os efeitos que o partidarismo teria exercido sobre o comportamento eleitoral na disputa presidencial. Esclarecer melhor essa questão é central para compreender como foi possível, diante da fragmentação, da volatilidade e da maioria de eleitores que não se identifica com partidos, que PSDB e PT tenham dominado a corrida presidencial no período de 1994 a 2006. É certo que a identidade partidária não é alta, mas quais são seus efeitos sobre o voto no PT e no PSDB? Como se posicionam nessa disputa os eleitores que se identificam com os outros dois grandes partidos, PMDB e PFL? E a avaliação que os eleitores fazem dos partidos explica mais o voto que a identidade? Essas questões serão respondidas na próxima seção. 


\subsection{Partidarismo na disputa presidencial entre PSDB e PT}

Os dados das pesquisas quantitativas utilizadas nesta tese confirmam os utilizados nas análises realizadas por outros autores, em especial por Carreirão \& Kinzo (2004), no que se refere à estabilidade em baixo patamar das taxas de preferência partidária durante o período da disputa entre PSDB e PT. Também confirmam uma tendência de crescimento no índice de identificação com o PT e de queda no índice de identificação com o PMDB, ainda que o mais correto seja afirmar que os índices dos quatro principais partidos oscilaram muito próximos à média observada, considerando-se todos os levantamentos. O PT obteve 15\% das preferências, seguido pelo PMDB, com 7\%, pelo PSDB, com 5\%, e pelo PFL, com 3\%. Segundo nossos dados, cerca de dois em cada três eleitores não têm preferência partidária, o que significa que, seguramente, serão baixos os efeitos desta variável sobre o resultado final das eleições.

Tabela 3: Preferência partidária nos anos de realização de eleição presidencial $^{3}$

\begin{tabular}{|l|c|c|c|c|c|c|c|c|c|}
\hline Partido & $\mathbf{1 9 9 4}$ & $\begin{array}{c}\mathbf{1 9 9 8} \\
\text { r1 }\end{array}$ & $\begin{array}{c}\mathbf{1 9 9 8} \\
\text { r2 }\end{array}$ & $\begin{array}{c}\mathbf{2 0 0 2} \\
\text { I r6.1 }\end{array}$ & $\begin{array}{c}\mathbf{2 0 0 2 -} \\
\text { I r6.2 }\end{array}$ & $\begin{array}{c}\mathbf{2 0 0 2} \\
\text { I r8 }\end{array}$ & $\begin{array}{c}\mathbf{2 0 0 2} \\
\text { E }\end{array}$ & $\begin{array}{c}\mathbf{2 0 0 6} \\
\text { r1 }\end{array}$ & $\begin{array}{c}\mathbf{2 0 0 6} \\
\text { r3 }\end{array}$ \\
\hline PT & 11,3 & 10,0 & 10,6 & 15,6 & 27,6 & 17,0 & 25,6 & 17,2 & 15,4 \\
\hline PSDB & 6,5 & 4,7 & 4,4 & 2,9 & 5,7 & 2,3 & 4,5 & 7,6 & 4,8 \\
\hline PMDB & 12,3 & 8,1 & 10,4 & 6,1 & 10,2 & 4,5 & 7,2 & 5,4 & 6,5 \\
\hline PFL & 2,8 & 3,2 & 3,1 & 3,1 & 4,7 & 3,2 & 3,4 & 1,4 & 1,5 \\
\hline Outros & 7,4 & 5,2 & 6,0 & 4,2 & 9,1 & 4,0 & 4,0 & 4,0 & 3,0 \\
\hline $\begin{array}{l}\text { Nenhum/Não } \\
\text { sabe }\end{array}$ & 59,7 & 68,9 & 65,6 & 68,0 & 42,7 & 69,0 & 55,3 & 64,4 & 68,7 \\
\hline
\end{tabular}

Fonte: 1994: Datafolha; 1998: Vox Populi; 2002 I: Ipsos Opinion; 2002 E: ESEB; 2006: Analítica Consultoria.

Se a preferência partidária nos quatro principais partidos dificilmente ultrapassa o índice de 30\%, é necessário analisar os efeitos do partidarismo

\footnotetext{
${ }^{3}$ Pergunta 1994: Qual é o seu partido de preferência? Pergunta 1998: Você tem simpatia por algum partido político? Se sim, qual? Pergunta 2002 - Ipsos Opinion r6.1 e r8: O(a) Sr(a) diria que tem um partido político, assim como ter um time de futebol que, aconteça o que acontecer, o Sr(a) sempre apóia e torce por ele ? Se sim, qual? Pergunta 2002 - Ipsos Opinion r6.2: Desses partidos, qual o sr(a) prefere? (estimulada); Pergunta 2002 - ESEB: De modo geral, existe algum partido político que o sr(a) goste? Se sim, qual? Pergunta 2006: $\mathrm{O}$ (a) $\mathrm{Sr}(\mathrm{a})$ tem preferência ou simpatia por algum partido político ?
} 
sobre o comportamento eleitoral de uma forma diferente. Para isso, serão consideradas também as opiniões, positivas, negativas ou neutras, que os eleitores têm com relação aos partidos políticos. O principal problema dessa variável é que dispomos dela apenas para análise das eleições de 2002 e 2006, o que impedirá uma análise longitudinal mais acurada.

Tabela 4: Avaliação dos partidos ${ }^{4}$

\begin{tabular}{|l|c|c|c|c|c|}
\hline Opinião sobre os partidos & $\begin{array}{c}\mathbf{2 0 0 2} \\
\text { ESEB }\end{array}$ & $\begin{array}{c}\mathbf{2 0 0 2} \\
\text { I r1 }\end{array}$ & $\begin{array}{c}\mathbf{2 0 0 6} \\
\text { r1 }\end{array}$ & $\begin{array}{c}\mathbf{2 0 0 6} \\
\text { r3 }\end{array}$ & média \\
\hline PT \\
\hline Negativa & 25,8 & 28,5 & 33,5 & 32,6 & 30,1 \\
\hline Neutra & 26,2 & 15,7 & 26,2 & 25,1 & 23,3 \\
\hline Positiva & 48,1 & 55,8 & 40,3 & 42,3 & 46,6 \\
\hline \multicolumn{5}{|c|}{ PSDB } \\
\hline Negativa & 35,5 & 39,7 & 23,3 & 38,1 & 34,2 \\
\hline Neutra & 44,2 & 30,8 & 43,7 & 31,3 & 37,5 \\
\hline Positiva & 20,3 & 29,5 & 33,0 & 30,7 & 28,4 \\
\hline \multicolumn{7}{|c|}{ PMDB } \\
\hline Negativa & 32,3 & 34,4 & 22,5 & 37,1 & 31,6 \\
\hline Neutra & 39,7 & 24,8 & 39,0 & 25,7 & 32,2 \\
\hline Positiva & 27,9 & 40,8 & 38,5 & 37,3 & 36,1 \\
\hline \multicolumn{7}{|c|}{ PFL } \\
\hline Negativa & 39,4 & 39,4 & 28,1 & 39,1 & 36,5 \\
\hline Neutra & 43,1 & 29,1 & 50,4 & 38,6 & 40,3 \\
\hline Positiva & 17,5 & 31,4 & 21,5 & 22,3 & 23,2 \\
\hline
\end{tabular}

Fonte: 2002 I: Ipsos Opinion; 2002 E: ESEB; 2006: Analítica Consultoria

Os dados referentes à avaliação dos partidos em 2002 e 2006 revelam que o PT é o partido sobre o qual repousam as maiores parcelas de avaliações positivas. Mesmo durante a eleição de 2006, após a série de escândalos políticos em que se envolvera, mais de 40\% dos entrevistados o avaliam positivamente. A média observada nos quatro levantamentos é de

\footnotetext{
${ }^{4}$ Pergunta 2002 ESEB: Agora gostaria de saber com mais detalhes o que o(a) Sr(a) pensa de alguns partidos políticos. Por favor, use uma nota de 0 a 10 para indicar o quanto o(a) $\operatorname{Sr}(a)$ gosta do partido que eu vou mencionar. Zero significa que o(a) $\operatorname{Sr}(a)$ NÃO gosta do partido e dez que o(a) Sr(a) gosta muito. Quando eu falar o nome de um partido que o(a) Sr(a) não conhece, apenas diga que não o conhece. Pergunta 2002 Ipsos Opinion: Para cada partido que eu mencionar, por favor, diga-me se o(a) $\mathrm{Sr}(\mathrm{a})$ tem uma impressão muito positiva, positiva, negativa ou muito negativa. Pergunta 2006: Para cada partido que eu citar, por favor diga-me se a impressão que ele passa para o(a) Sr(a) é: muito boa, boa, regular, ruim ou muito ruim?
} 
$47 \%$ de avaliações positivas, $23 \%$ neutras e $30 \%$ negativas. O PMDB é o segundo partido com maior média de avaliações positivas, com 36\%, seguido de PSDB, com 28\%, e pelo PFL, com 23\%. Com relação às avaliações negativas, o PFL é o que obtém a maior média, com 37\%, seguido do PSDB, com 34\%, e do PMDB, com 32\%. A partir desses dados, percebe-se que a maioria dos eleitores brasileiros é capaz de avaliar os partidos e, provavelmente, essa avaliação tem maior poder explicativo e preditivo sobre o comportamento eleitoral.

A partir da revisão da literatura sobre os partidos na arena eleitoral, a formulação de uma hipótese sobre essa questão não é fácil. O Brasil passa por uma situação em que é importante consolidar partidos. Estes, contudo, nas democracias atualmente consolidadas, já não fazem mais tanto sentido para os eleitores quanto faziam no passado. Por outro lado, a continuidade da disputa entre PSDB e PT não apenas sugere que o partidarismo tem relevância, como nos faz esperar que tal relevância seja crescente. Assim, a hipótese aqui é que as diferenças entre os eleitores com e sem identificação partidária devem ser crescentes, assim como a capacidade explicativa e preditiva dos modelos partidários de decisão de voto.

\subsubsection{Modelos logísticos para ocorrência de voto em PSDB e PT com preferência partidária}

O modelo de regressão logística para a ocorrência de voto no PSDB apenas com a covariável indicadora da preferência por este partido mostra que saber se o eleitor é ou não tucano explica muito pouco o voto no partido. Durante todo o período, as chances de um eleitor que tem preferência pelo PSDB votar no partido foram entre 6,5 e 12 vezes maiores que as chances de um eleitor sem essa preferência. Essa grande diferença entre as chances não faz com que o modelo tenha sequer razoável capacidade de explicar ou de prever o voto no partido. Os modelos não chegaram a obter $R^{2}$ superiores a 0,1 , e os votos no PSDB previstos corretamente pelo modelo nunca ultrapassaram os 16\%. Ao longo do tempo, essas características pouco se alteram, mas os melhores modelos são observados em 2006 e os piores em 2002. 
Quadro 21: Modelo de regressão logística para a ocorrência de voto no PSDB - Preferência pelo PSDB $\left({ }^{a}\right)$

\begin{tabular}{|c|c|c|c|c|c|c|}
\hline & $\begin{array}{c}\text { Modelo } \\
1994\end{array}$ & $\begin{array}{c}\text { Modelo } \\
1998\end{array}$ & $\begin{array}{c}\text { Modelo } \\
2002 \\
1^{\circ} \text { turno } \\
\end{array}$ & $\begin{array}{c}\text { Modelo } \\
2002 \\
2^{\circ} \text { turno } \\
\end{array}$ & $\begin{array}{c}\text { Modelo } \\
2006 \\
1^{\circ} \text { turno } \\
\end{array}$ & $\begin{array}{c}\text { Modelo } \\
2006 \\
2^{\circ} \text { turno } \\
\end{array}$ \\
\hline \multicolumn{7}{|l|}{$\begin{array}{l}\text { VARIÁVEIS } \\
\text { PARTIDÁRIAS }\end{array}$} \\
\hline $\begin{array}{l}\text { Preferência } \\
\text { pelo PSDB }\end{array}$ & $\begin{array}{c}10,913(* *) \\
(0,26)\end{array}$ & $\begin{array}{c}10,680(* *) \\
(0,23)\end{array}$ & $\begin{array}{c}6,489(* *) \\
(0,2)\end{array}$ & $\begin{array}{c}6,431(* *) \\
(0,2)\end{array}$ & $\begin{array}{c}10,246\left(^{(\star *}\right) \\
(0,26)\end{array}$ & $\begin{array}{c}11,225\left(^{* *}\right) \\
(0,3)\end{array}$ \\
\hline $\begin{array}{l}\mathrm{R}^{2} \\
\mathrm{~N}\end{array}$ & $\begin{array}{c}0,07 \\
2.500\end{array}$ & $\begin{array}{c}0,07 \\
3.200\end{array}$ & $\begin{array}{c}0,06 \\
2.512\end{array}$ & $\begin{array}{c}0,05 \\
2.512\end{array}$ & $\begin{array}{c}0,09 \\
1.600\end{array}$ & $\begin{array}{c}0,08 \\
1.600\end{array}$ \\
\hline $\begin{array}{l}\text { Casos previstos } \\
\text { corretamente } \\
\text { Votos no PSDB }\end{array}$ & $58 \%$ & $69 \%$ & $82 \%$ & $77 \%$ & $81 \%$ & $72 \%$ \\
\hline $\begin{array}{l}\text { previstos corretamente } \\
\text { Previsões de voto no }\end{array}$ & $12 \%$ & $11 \%$ & $14 \%$ & $12 \%$ & $16 \%$ & $13 \%$ \\
\hline PSDB corretas & $90 \%$ & $83 \%$ & $57 \%$ & $66 \%$ & $69 \%$ & $82 \%$ \\
\hline Chance na base & $44 \%$ & $32 \%$ & $17 \%$ & $23 \%$ & $18 \%$ & $28 \%$ \\
\hline
\end{tabular}

Notas: $\left({ }^{a}\right)$ A preferência pelos partidos foi operacionalizada da seguinte forma: sem preferência $=0$; com preferência $=1 .\left({ }^{*}\right) p<0,05 .\left({ }^{* *}\right) p<0,01$.

Fonte: 1994: Datafolha (1994); 1998: Vox Populi (1998); 2002: Almeida et al. (2002); 2006: Analítica Consultoria (2006).

Apenas a informação sobre a preferência pelo PSDB restringe demais o possível impacto da preferência partidária para explicar e prever o voto no partido, uma vez que importa saber como se posicionam os demais partidários. Nesse caso, considerando que o PSDB foi apoiado pelo PFL, em 1994, 1998 e 2006 e pelo PMDB, em 2002, deveríamos observar a formação de uma frente desses partidos contra o PT.

O acréscimo das covariáveis indicadoras das preferências pelo PT, pelo PMDB e pelo PFL melhora consideravelmente a qualidade explicativa e preditiva do modelo de voto no PSDB. Todas as razões de chance indicam a formação da frente em apoio ao candidato do partido, e a maioria é significativa pelo menos ao nível de 5\%. É possível perceber, pelos níveis de significância, que a realização de um segundo turno mitiga o apoio de peemedebistas e pefelistas ao PSDB. Isso parece uma indicação de que as alianças partidárias construídas no primeiro turno se enfraquecem ao longo da campanha.

Os $\mathrm{R}^{2}$ observados elevam-se significativamente, em comparação ao modelo bivariado, porém são praticamente constantes ao longo do tempo, e o percentual de votos no PSDB previstos corretamente é declinante. Ou seja: ao menos para o voto no PSDB, o partidarismo parece ter perdido força entre 1994 e 2006, o que contraria nossas expectativas com relação ao papel eleitoral dos partidos. 
Quadro 22: Modelo de regressão logística para a ocorrência de voto no PSDB - Preferência pelo PT, PSDB, PMDB e PFL $\left(^{a}\right)$

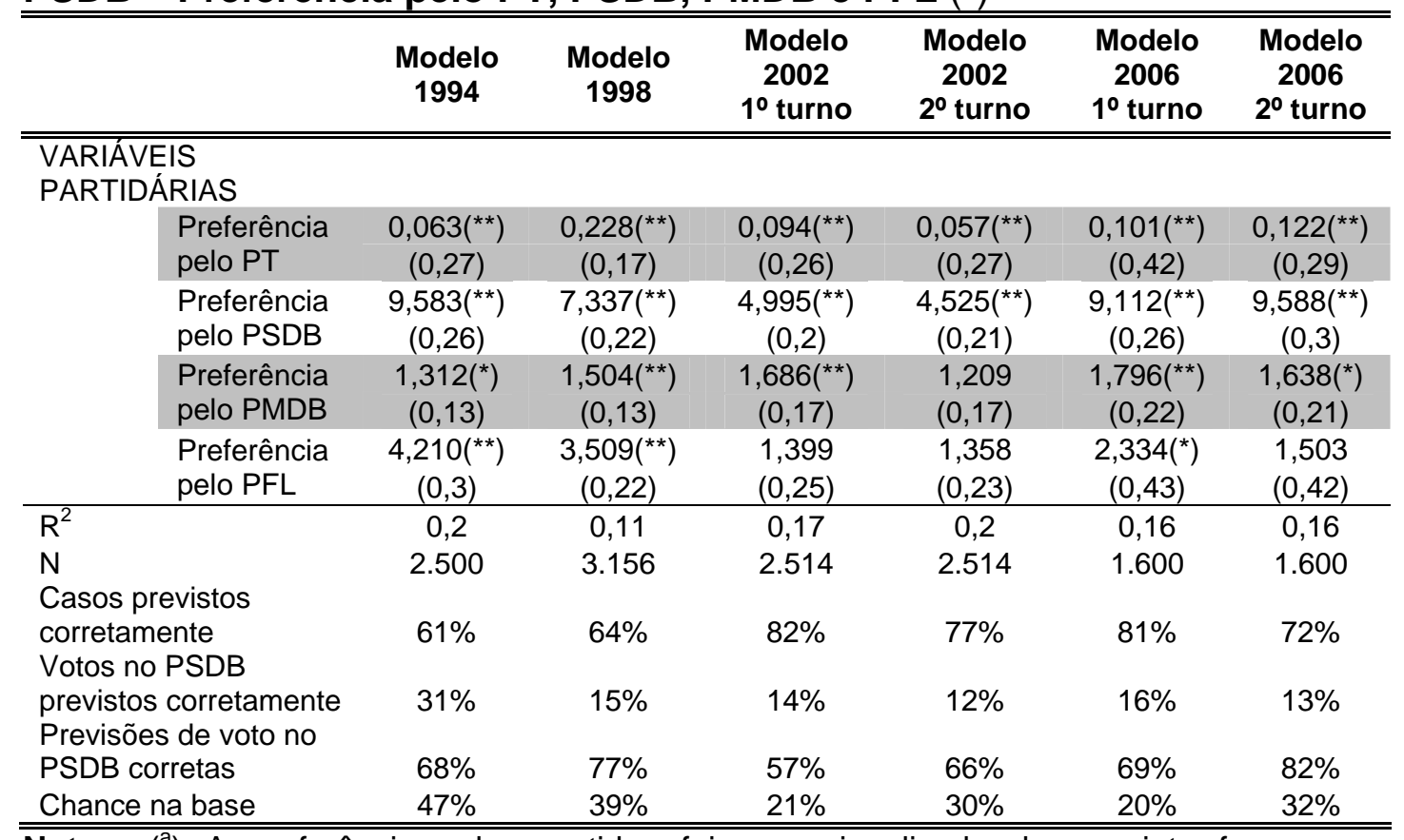

Notas: $\left({ }^{a}\right)$ A preferência pelos partidos foi operacionalizada da seguinte forma: sem preferência $=0$; com preferência $\left.=1 .{ }^{*}\right) p<0,05 .\left({ }^{* *}\right) p<0,01$.

Fonte: 1994: Datafolha (1994); 1998: Vox Populi (1998); 2002: Almeida et al. (2002); 2006: Analítica Consultoria (2006).

O PT sempre foi considerado pelos analistas como um partido diferenciado em nosso sistema político. Muito se falou sobre sua capacidade política e organizativa, que lhe permitiu constantemente conquistar mais e melhores cargos abertos à disputa eleitoral. Além disso, como vimos, é o partido com mais adesões e que goza de melhor avaliação entre os eleitores. Contudo, o papel exercido pelos petistas no modelo de voto do partido é francamente declinante.

Na primeira eleição aqui analisada, um eleitor petista tem chance 39 vezes maior de votar no partido do que um não petista. O modelo bivariado consegue explicar e prever consistentemente o comportamento em relação ao partido em 1994, entretanto, na medida em que as eleições se sucedem e o eleitorado que vota no PT se torna maior, o eleitor petista se torna menos relevante para o resultado obtido pelo partido. 
Quadro 23: Modelo de regressão logística para a ocorrência de voto no PT - Preferência pelo PT $\left({ }^{a}\right)$

\begin{tabular}{|c|c|c|c|c|c|c|}
\hline & $\begin{array}{l}\text { Modelo } \\
1994\end{array}$ & $\begin{array}{l}\text { Modelo } \\
1998\end{array}$ & $\begin{array}{l}\text { Modelo } \\
2002 \\
1^{\circ} \text { turno }\end{array}$ & $\begin{array}{l}\text { Modelo } \\
2002 \\
2^{\circ} \text { turno }\end{array}$ & $\begin{array}{l}\text { Modelo } \\
2006 \\
1^{\circ} \text { turno }\end{array}$ & $\begin{array}{l}\text { Modelo } \\
2006 \\
2^{\circ} \text { turno }\end{array}$ \\
\hline \multicolumn{7}{|l|}{$\begin{array}{l}\text { VARIÁVEIS } \\
\text { PARTIDÁRIAS }\end{array}$} \\
\hline $\begin{array}{l}\text { Preferência } \\
\text { pelo PT } \\
\end{array}$ & $\begin{array}{c}39,085(* \star \\
(0,18) \\
\end{array}$ & $\begin{array}{c}16,863(* *) \\
(0,15) \\
\end{array}$ & $\begin{array}{c}5,561(* \star) \\
(0,1)\end{array}$ & $\begin{array}{c}4,566(* *) \\
(0,1) \\
\end{array}$ & $\begin{array}{c}6,658(* *) \\
(0,18) \\
\end{array}$ & $\begin{array}{c}11,981\left(^{* *}\right) \\
(0,24)\end{array}$ \\
\hline $\mathrm{R} 2$ & 0,35 & 0,21 & 0,16 & 0,12 & 0,11 & 0,14 \\
\hline $\begin{array}{l}\mathrm{N} \\
\text { Casos previstos }\end{array}$ & 2.500 & 3.156 & 2.514 & 2.514 & 1.600 & 1.600 \\
\hline $\begin{array}{l}\text { corretamente } \\
\text { Votos no PT previstos }\end{array}$ & $87 \%$ & $83 \%$ & $69 \%$ & $61 \%$ & $60 \%$ & $57 \%$ \\
\hline $\begin{array}{l}\text { corretamente } \\
\text { Previsões de voto no }\end{array}$ & $45 \%$ & $33 \%$ & $44 \%$ & $37 \%$ & $25 \%$ & $25 \%$ \\
\hline PT corretas & $86 \%$ & $79 \%$ & $73 \%$ & $79 \%$ & $86 \%$ & $92 \%$ \\
\hline Chance na base & $13 \%$ & $18 \%$ & $32 \%$ & $46 \%$ & $45 \%$ & $50 \%$ \\
\hline
\end{tabular}

Notas: $\left({ }^{a}\right)$ A preferência pelos partidos foi operacionalizada da seguinte forma: sem preferência $=0$; com preferência $=1 .\left({ }^{*}\right) p<0,05 .\left({ }^{* *}\right) p<0,01$.

Fonte: 1994: Datafolha (1994); 1998: Vox Populi (1998); 2002: Almeida et al. (2002); 2006: Analítica Consultoria (2006).

O modelo de regressão logística para a ocorrência de voto no PT com as indicadoras dos quatro principais partidos como covariáveis acrescenta muito pouco ao modelo, quando comparado ao bivariado, diferentemente do que se observa no modelo do PSDB. Além disso, saber se o eleitor tem preferência ou não por PMDB e PFL informa muito pouco sobre o voto no partido. Ainda que as razões de chance sejam quase todas no sentido esperado, nenhuma é significante ao nível de 5\%, o que nos permite afirmar que o voto no PT é independente da preferência pelo PMDB e pelo PFL. Da mesma forma que o modelo bivariado, ser petistas se torna progressivamente menos importante para a decisão de voto no PT.

Os dados apresentados sugerem uma erosão das bases eleitorais partidárias nas eleições presidenciais. Se para o PSDB essa variável nunca foi muito importante, para o PT deixa de ser durante o período em que ambos protagonizaram a disputa. Com relação ao PMDB e ao PFL, verifica-se que o apoio desses partidos à candidatura tucana não acrescenta muito aos modelos, perde força ao longo do tempo e, principalmente, parece perder ainda mais nas decisões em segundo turno, justamente quando deveriam ser mais importantes. 
Quadro 24: Modelo de regressão logística para a ocorrência de voto no PT - Preferência pelo PT, PSDB, PMDB e PFL $\left(^{\mathrm{a}}\right)$

\begin{tabular}{|c|c|c|c|c|c|c|}
\hline & $\begin{array}{c}\text { Modelo } \\
1994\end{array}$ & $\begin{array}{l}\text { Modelo } \\
1998\end{array}$ & $\begin{array}{c}\text { Modelo } \\
2002 \\
1^{\circ} \text { turno }\end{array}$ & $\begin{array}{c}\text { Modelo } \\
2002 \\
2^{\circ} \text { turno }\end{array}$ & $\begin{array}{c}\text { Modelo } \\
2006 \\
1^{\circ} \text { turno }\end{array}$ & $\begin{array}{c}\text { Modelo } \\
2006 \\
2^{\circ} \text { turno }\end{array}$ \\
\hline \multicolumn{7}{|l|}{$\begin{array}{l}\text { VARIÁVEIS } \\
\text { PARTIDÁRIAS }\end{array}$} \\
\hline $\begin{array}{l}\text { Preferência } \\
\text { pelo PT }\end{array}$ & $\begin{array}{c}35,218(* *) \\
(0,18)\end{array}$ & $\begin{array}{c}15,680(* *) \\
(0,15)\end{array}$ & $\begin{array}{c}5,211(* *) \\
(0,1)\end{array}$ & $\begin{array}{c}4,310\left(^{* *}\right) \\
(0,11)\end{array}$ & $\begin{array}{c}6,161(* *) \\
(0,19)\end{array}$ & $\begin{array}{c}10,966(* *) \\
(0,25)\end{array}$ \\
\hline $\begin{array}{l}\text { Preferência } \\
\text { pelo PSDB }\end{array}$ & $\begin{array}{c}0,203(* \star) \\
(0,44)\end{array}$ & $\begin{array}{c}0,28(* *) \\
(0,35)\end{array}$ & $\begin{array}{c}0,348\left(^{\star *}\right) \\
(0,27)\end{array}$ & $\begin{array}{c}0,254(* \star) \\
(0,25)\end{array}$ & $\begin{array}{c}0,215(* \star) \\
(0,32)\end{array}$ & $\begin{array}{c}0,170\left(^{* *}\right) \\
(0,32)\end{array}$ \\
\hline $\begin{array}{l}\text { Preferência } \\
\text { pelo PMDB }\end{array}$ & $\begin{array}{l}0,855 \\
(0,19)\end{array}$ & $\begin{array}{l}0,844 \\
(0,18)\end{array}$ & $\begin{array}{l}0,996 \\
(0,17)\end{array}$ & $\begin{array}{l}1,147 \\
(0,16)\end{array}$ & $\begin{array}{l}0,956 \\
(0,21)\end{array}$ & $\begin{array}{c}0,953 \\
(0,2)\end{array}$ \\
\hline $\begin{array}{l}\text { Preferência } \\
\text { pelo PFL }\end{array}$ & $\begin{array}{l}0,583 \\
(0,42)\end{array}$ & $\begin{array}{l}0,642 \\
(0,30)\end{array}$ & $\begin{array}{l}0,740 \\
(0,25)\end{array}$ & $\begin{array}{l}0,981 \\
(0,22)\end{array}$ & $\begin{array}{l}0,857 \\
(0,41)\end{array}$ & $\begin{array}{l}0,913 \\
(0,41)\end{array}$ \\
\hline $\mathrm{R}^{2}$ & 0,36 & 0,22 & 0,17 & 0,14 & 0,14 & 0,18 \\
\hline $\mathrm{N}$ & 2.500 & 3.156 & 2.514 & 2.514 & 1.600 & 1.600 \\
\hline $\begin{array}{l}\text { Casos previstos } \\
\text { corretamente } \\
\text { Votos no PT previstos }\end{array}$ & $87 \%$ & $82 \%$ & $69 \%$ & $61 \%$ & $60 \%$ & $60 \%$ \\
\hline $\begin{array}{l}\text { corretamente } \\
\text { Previsões de voto no }\end{array}$ & $45 \%$ & $33 \%$ & $44 \%$ & $44 \%$ & $25 \%$ & $97 \%$ \\
\hline PT corretas & $86 \%$ & $79 \%$ & $73 \%$ & $73 \%$ & $85 \%$ & $58 \%$ \\
\hline Chance na base & $15 \%$ & $19 \%$ & $34 \%$ & $47 \%$ & $47 \%$ & $52 \%$ \\
\hline
\end{tabular}

Notas: $\left({ }^{a}\right)$ A preferência pelos partidos foi operacionalizada da seguinte forma: sem preferência $=0$; com preferência $=1 .\left(^{*}\right) p<0,05 .\left({ }^{* *}\right) p<0,01$.

Fonte: 1994: Datafolha (1994); 1998: Vox Populi (1998); 2002: Almeida et al. (2002); 2006: Analítica Consultoria (2006).

\subsubsection{Modelos logísticos para ocorrência de voto em PSDB e PT com} avaliação dos partidos

Como a hipótese sobre a consolidação dos partidos na eleição presidencial não se confirma a partir da análise da preferência partidária, uma vez que esta progressivamente se torna menos influente nos resultados eleitorais, cabe buscar uma medida mais ampla de partidarismo. Como foi sugerido por Almeida (2006) e por Carreirão \& Barbetta (2004), é necessário tomar indicadores mais flexíveis, para que possamos descartar ou não a influência eleitoral dos partidos sob o ponto de vista dos eleitores. Nesse sentido, o sentimento partidário pode ser uma forma melhor, porque mais ampla, para explicar o comportamento eleitoral.

De fato, tanto no caso do PSDB, como no do PT, a adoção das covariáveis com a avaliação dos partidos melhorou o ajuste dos modelos, que explicam mais e prevêem melhor, mas não o suficiente para explicar mais de $30 \%$ do comportamento eleitoral. 
No caso dos modelos do PSDB, as razões de chance indicam que avaliações negativas do PT e positivas do PSDB e PMDB sempre favorecem o candidato tucano. Contudo, o voto no PSDB em 2006 é independente da avaliação que o eleitor faz do PFL, ainda que naquele ano os dois partidos estivessem aliados. Diferentemente do que ocorria quando considerávamos a preferência partidária, no caso do PSDB a avaliação dos partidos é uma explicação melhor no segundo turno das eleições. Nesses casos, os $\mathrm{R}^{2}$ ultrapassam 0,2 e os modelos prevêem mais de um terço dos votos no partido.

Quadro 25: Modelo de regressão logística para a ocorrência de voto no PSDB - Avaliação do PT, PSDB, PMDB e PFL ( $\left.{ }^{a}\right)$

\begin{tabular}{|c|c|c|c|c|c|}
\hline & & $\begin{array}{c}\text { Modelo } \\
2002 \\
1^{\circ} \text { turno }\end{array}$ & $\begin{array}{c}\text { Modelo } \\
2002 \\
2^{\circ} \text { turno }\end{array}$ & $\begin{array}{c}\text { Modelo } \\
2006 \\
1^{\circ} \text { turno }\end{array}$ & $\begin{array}{c}\text { Modelo } \\
2006 \\
2^{\circ} \text { turno }\end{array}$ \\
\hline \multicolumn{6}{|c|}{ VARIÁVEIS PARTIDÁRIAS } \\
\hline & Avaliação do PT & $\begin{array}{c}0,386(* *) \\
(0,1)\end{array}$ & $\begin{array}{c}0,3(\star \star \\
(0,1)\end{array}$ & $\begin{array}{c}0,380(* *) \\
(0,1)\end{array}$ & $\begin{array}{c}0,341(* *) \\
(0,1)\end{array}$ \\
\hline & Avaliação do PSDB & $\begin{array}{c}1,488 \text { (**) } \\
(0,1)\end{array}$ & $\begin{array}{c}1,68(* \star) \\
(0,1)\end{array}$ & $\begin{array}{c}2,023(* *) \\
(0,1)\end{array}$ & $\begin{array}{c}\left.1,908{ }^{* *}\right) \\
(0,1)\end{array}$ \\
\hline & Avaliação do PMDB & $\begin{array}{c}1,186\left(^{*}\right) \\
(0,1)\end{array}$ & $\begin{array}{c}1,302\left(^{* *}\right) \\
(0,1)\end{array}$ & $\begin{array}{c}1,247\left(^{*}\right) \\
(0,1)\end{array}$ & $\begin{array}{c}\left.1,305^{(* *}\right) \\
(0,1)\end{array}$ \\
\hline & Avaliação do PFL & $\begin{array}{c}1,199\left(^{*}\right) \\
(0,1)\end{array}$ & $\begin{array}{c}1,274\left(^{* \star}\right) \\
(0,1)\end{array}$ & $\begin{array}{c}0,976 \\
(0,1)\end{array}$ & $\begin{array}{c}1,012 \\
(0,1)\end{array}$ \\
\hline \multicolumn{2}{|l|}{$\mathrm{R}^{2}$} & 0,18 & 0,29 & 0,19 & 0,23 \\
\hline \multicolumn{2}{|c|}{$\mathrm{N}$} & 2.514 & 2.514 & 1.600 & 1.600 \\
\hline \multicolumn{2}{|c|}{ Casos previstos corretamente } & $81 \%$ & $80 \%$ & $81 \%$ & $75 \%$ \\
\hline \multicolumn{2}{|c|}{ Previsões de voto no PSDB } & $10 \%$ & $42 \%$ & $23 \%$ & $35 \%$ \\
\hline \multicolumn{2}{|c|}{ corretas } & $47 \%$ & $66 \%$ & $57 \%$ & $69 \%$ \\
\hline \multicolumn{2}{|c|}{ Chance na base } & $20 \%$ & $32 \%$ & $19 \%$ & $30 \%$ \\
\hline
\end{tabular}

Notas: $\left({ }^{a}\right)$ Nesta variável, o zero foi definido como avaliação neutra, -1 como negativa e 1 como positiva. $\left(^{\star}\right) p<0,05$. $\left({ }^{*}\right) p<0,01$.

Fonte: 2002: Almeida et al. (2002); 2006: Analítica Consultoria (2006).

Comparativamente, os modelos para o PT são ligeiramente superiores aos modelos para o PSDB. Ou seja: conhecer as opiniões sobre os partidos informa mais sobre o voto no PT do que sobre o voto no PSDB. Assim como os modelos com as covariáveis indicadoras da preferência partidária, as avaliações de PMDB e PFL pouco dizem respeito ao comportamento com relação ao PT, e a maior parte das razões de chance não é estatisticamente significante. 
Quadro 26: Modelo de regressão logística para a ocorrência de voto no PT - Avaliação do PT, PSDB, PMDB e PFL $\left({ }^{\mathrm{a}}\right)$

\begin{tabular}{|c|c|c|c|c|c|}
\hline & & $\begin{array}{c}\text { Modelo } \\
2002 \\
1^{\circ} \text { turno }\end{array}$ & $\begin{array}{c}\text { Modelo } \\
2002 \\
2^{\circ} \text { turno }\end{array}$ & $\begin{array}{c}\text { Modelo } \\
2006 \\
1^{\circ} \text { turno }\end{array}$ & $\begin{array}{c}\text { Modelo } \\
2006 \\
2^{\circ} \text { turno }\end{array}$ \\
\hline \multicolumn{6}{|c|}{ VARIÁVEIS PARTIDÁRIAS } \\
\hline & Avaliação do PT & $\begin{array}{c}3,085(* *) \\
(0,1)\end{array}$ & $\begin{array}{l}2,820(* \star \\
(0,1)\end{array}$ & $\begin{array}{c}3,489(* *) \\
(0,1)\end{array}$ & $\begin{array}{c}3,291\left({ }^{* *}\right) \\
(0,1)\end{array}$ \\
\hline & Avaliação do PSDB & $\begin{array}{c}0,698(* *) \\
(0,1)\end{array}$ & $\begin{array}{c}0,644(* *) \\
(0,1)\end{array}$ & $\begin{array}{c}0,644(* *) \\
(0,1)\end{array}$ & $\begin{array}{c}0,625(* *) \\
(0,1)\end{array}$ \\
\hline & Avaliação do PMDB & $\begin{array}{c}0,893 \\
(0,1)\end{array}$ & $\begin{array}{c}0,876\left(^{*}\right) \\
(0,1)\end{array}$ & $\begin{array}{c}0,935 \\
(0,1)\end{array}$ & $\begin{array}{c}0,911 \\
(0,1)\end{array}$ \\
\hline & Avaliação do PFL & $\begin{array}{c}0,795(* *) \\
(0,1)\end{array}$ & $\begin{array}{c}0,884 \\
(0,1)\end{array}$ & $\begin{array}{c}1,001 \\
(0,1)\end{array}$ & $\begin{array}{c}1,038 \\
(0,1)\end{array}$ \\
\hline \multicolumn{2}{|l|}{$\mathrm{R}^{2}$} & 0,25 & 0,24 & 0,28 & 0,26 \\
\hline \multicolumn{2}{|c|}{$\mathrm{N}$} & 2.514 & 2.514 & 1.600 & 1.600 \\
\hline \multicolumn{2}{|c|}{$\begin{array}{l}\text { Casos previstos corretamente } \\
\text { Votos no PT previstos }\end{array}$} & $71 \%$ & $69 \%$ & $72 \%$ & $68 \%$ \\
\hline \multicolumn{2}{|c|}{$\begin{array}{l}\text { corretamente } \\
\text { Previsões de voto no PT }\end{array}$} & $66 \%$ & $73 \%$ & $67 \%$ & $77 \%$ \\
\hline \multirow{2}{*}{\multicolumn{2}{|c|}{$\begin{array}{l}\text { corretas } \\
\text { Chance na base }\end{array}$}} & $65 \%$ & $71 \%$ & $75 \%$ & $70 \%$ \\
\hline & & $32 \%$ & $46 \%$ & $48 \%$ & $54 \%$ \\
\hline
\end{tabular}

Notas: $\left({ }^{a}\right)$ Nesta variável, o zero foi definido como avaliação neutra, -1 como negativa e 1 como positiva. $\left(^{*}\right) p<0,05$. $\left(^{* *}\right) p<0,01$.

Fonte: 2002: Almeida et al. (2002); 2006: Analítica Consultoria (2006).

Com os dados disponíveis apenas para 2002 e 2006, não é possível observar tendências, mas é possível reforçar a conclusão de que, sob o ponto de vista do eleitor, os partidos contam pouco na decisão de voto. Mesmo adotando uma medida mais ampla, pode-se explicar menos de um terço das intenções de voto. Em outras palavras, as posições que os eleitores adotam frente aos partidos importam pouco para os resultados eleitorais nas eleições presidenciais.

Em resumo, com relação ao papel dos partidos na decisão de voto no Brasil, pode-se afirmar com segurança que, ao nível do eleitor, o sistema partidário e suas diversas siglas não fazem sentido na arena eleitoral. Isso se expressa claramente na fragmentação partidária, na volatilidade eleitoral, nos baixos patamares de identificação partidária e da fraca aderência desta ao voto. Se não é o partido que importa no momento do voto, talvez a ideologia seja. 


\subsection{Ideologia na decisão do voto no Brasil}

Não foram poucos os pesquisadores que salientaram a importância da ideologia em um modelo de decisão do voto - afinal, é uma das variáveis explicativas mais importantes da ciência política. De certa forma, a ideologia pode ser vista como um conjunto de valores fundamentais com as quais as pessoas se socializam desde a infância e no decorrer de sua vida, na escola, no trabalho, etc., ou seja, no ambiente social em que estão inseridas. Esse longo processo de socialização cria nos indivíduos certos valores que podem se tornar mais ou menos liberais, autoritários, moralistas, etc. No Brasil, diversas pesquisas importantes trataram das relações entre ideologia e voto. Desde o inicio da década de 60 até os dias atuais, os pesquisadores buscam entender melhor como se estabelecem e funcionam essas relações.

O primeiro trabalho importante é o de Soares (1961a). O autor examina dados de uma pesquisa amostral realizada na cidade do Rio de Janeiro e procura demonstrar que o voto em Carlos Lacerda seria consistentemente orientado pela ideologia. Assim, do ponto de vista econômico, quanto mais liberal o eleitor, maior a chance de votar em Lacerda, e quanto mais nacionalista, menor a chance. Dessa forma, existiria certo grau de coerência e previsibilidade no comportamento do eleitor.

Para o período do bipartidarismo, os trabalhos mais importantes, no que se refere à associação entre ideologia e voto, foram os organizados por Lamounier \& Cardoso (coords., 1978) e Reis (org., 1978). Em ambas as obras, o que se busca é a existência de algum padrão ideológico estruturado entre os eleitores brasileiros. De maneira geral, a conclusão dos autores é que a estruturação ideológica é algo restrito a uma camada diferenciada da população, em termos de maior grau de escolaridade ou maior capacidade cognitiva. Ainda que isso ocorra, não quer dizer que o eleitor brasileiro seja inconsistente ou incoerente; os pesquisadores apontam, por exemplo, que, quanto maior o apoio ao autoritarismo, maior a chance de voto na Arena e menor a chance de sufragar o MDB. Ideologicamente, as principais distinções entre os dois partidos adotadas pelo eleitorado são as generalizações do tipo elite versus povo, ou governo 
versus oposição, muito genéricas, destituídas de estruturação e sem matizes políticos mais complexos.

Os mesmos dados utilizados em Reis (org., 1978) foram estudados por Mettenhein (1995). Este autor procura elementos ideológicos mais amplos para sua análise e trata de enfatizar aspectos relacionados com nossa própria tradição política, dentre os quais o personalismo e o patrimonialismo. Também mostra dados para o Sudeste, sugerindo que o autoposicionamento em uma escala de esquerda a direita faz sentido para menos de um terço dos eleitores. Nesse grupo restrito de eleitores, observa-se coerência entre a posição ideológica e o voto.

Entretanto, o autor que busca analisar mais a fundo a questão do autoposicionamento ideológico em uma escala de esquerda a direita é Singer (2000). Sua tese é sobre o impacto do autoposicionamento no comportamento eleitoral nas eleições presidenciais de 1989 e 1994. Recorrendo a dados de pesquisa de opinião, o autor defende a idéia de que naquelas duas eleições a maioria do eleitorado soube se localizar em um contínuo esquerda-direita e que esse posicionamento estava fortemente associado à escolha do candidato em quem votar. Também observa 0 impacto da preferência partidária na definição do voto e mostra que, dentre as variáveis de longo prazo, foi a que se revelou mais associada à escolha do candidato. Contudo, apesar de ser excelente instrumento de predição do voto, o partidarismo tinha abrangência restrita a uma parcela pequena do eleitorado, cerca de 40\%. Assim, comparando partidarismo e ideologia, o autor defende a preponderância desta última, uma vez que consegue abarcar mais de $80 \%$ do eleitorado, e afirma que, "quando comparada a outras variáveis preditivas do voto naquelas ocasiões, a identificação ideológica revelou-se das mais fortes" (Singer, 2000, p. 17).

Uma crítica geral ao trabalho de Singer é que não foram utilizadas técnicas de análise multivariada, o que permitiria controlar as variáveis e saber qual peso explicativo cada uma tem na explicação do voto. Os estudos mais recentes têm utilizado novas técnicas e procurado investigar novas medidas, para dar conta da complexidade da ideologia como conceito importante para a compreensão do comportamento político. 
Com relação a esses dois aspectos, o trabalho de Almeida \& Young (2002) representa importante avanço. Influenciados por Reis (org., 1978) e Soares (1961a e 1961b) e diferentemente de Singer (2000), eles investigam a ideologia para além do contínuo esquerda-direita, utilizam baterias de perguntas que medem valores fundamentais relacionados à presença do estado na economia, ao autoritarismo com relação aos direitos individuais e a uma cidadania impessoal e secular, e adotam técnicas de análise multivariada. Os diversos constructos são analisados a partir de uma tipologia que combina as dimensões esquerda-direita e delegativo-não delegativo. A partir deles, são elaborados modelos explicativos para o voto em Lula em 1998 e em 2002, para o voto em Fernando Henrique em 1998 e Roseana em 2002, e para Garotinho e Ciro em 2002. Os autores concluem que "é possível diferenciar o eleitorado segundo características de visão de mundo, que variáveis dessa natureza são importantes para explicar o voto a presidente (explicam aproximadamente 30\% do voto), e que as dimensões ideológicas relevantes não se resumem apenas ao contínuo esquerda - direita, tradicionalmente utilizado nos países desenvolvidos, mas que há um outro contínuo igualmente relevante para o modelo explicativo, o eixo delegativo não-delegativo" (cf. Almeida \& Young, p. 17, 2002).

O trabalho de Almeida \& Young (2002) apresenta dados de pesquisa realizada no Rio de Janeiro em 2001 que serviu como piloto para a Pesquisa Social Brasileira (Pesb) e para o Estudo Eleitoral Brasileiro (Eseb) em 2002. Camargo (2005) utilizou os dados do Eseb e procurou reproduzir o que Almeida \& Young (2002) haviam feito, chegando a conclusões semelhantes: ou seja, mesmo tendo como universo o conjunto do eleitorado brasileiro, certos valores ideológicos - como o liberalismo, o patrimonialismo e o fatalismo - são significantes para o comportamento eleitoral.

Em suma, diversos autores apontam para a importância das posições ideológicas para a decisão de voto. Ainda que não consigam explicar muito o voto, todas as medidas adotadas estão, em alguma medida, associadas ao comportamento eleitoral. 


\subsubsection{Ideologia na disputa PSDB-PT}

A análise de Downs (1999) é de grande valia para a compreensão do processo eleitoral brasileiro a partir de 1994. Apesar de vivenciarmos um sistema multipartidário, no qual os partidos deveriam assumir posições ideológicas mais claras, a experiência eleitoral e governamental que temos dilui as ideologias partidárias. Sem dúvida, PT e PSDB sempre visaram à diferenciação ideológica, especialmente o primeiro. Contudo, a busca pela vitória nas eleições e pela governabilidade levou-os a construir alianças eleitorais e coalizões governamentais que, ao nível federal, aproximam nosso sistema pluripartidário de um sistema bipartidário. É claro que essa aproximação ocorre notadamente na disputa presidencial, mas a verticalização das alianças promove uma espécie de bipartidarismo também em muitos estados, em particular naqueles em que esses dois partidos se tornaram mais fortes, como São Paulo, Rio Grande do Sul e Pará.

A diluição ideológica causada pelas alianças eleitorais de petistas e tucanos também levou essas agremiações a viverem importantes conflitos internos que opuseram os defensores da coesão ideológica e os que advogavam a ampliação das alianças como meio para se chegar ao poder. Se os partidos e os eleitores estão dispostos em um contínuo esquerdadireita e se a maior parcela dos eleitores brasileiros se posiciona nesse contínuo próxima do centro, os partidos precisam ocupar esse espaço para obter êxito eleitoral. Isso significa dizer que as diversas agremiações que compõem o sistema partidário brasileiro, realizando sempre alianças eleitorais e coalizões governamentais, não conseguem se distinguir com clareza aos olhos dos eleitores, fazendo esperar que a ideologia não seja muito relevante para a decisão eleitoral. É claro que certas posições ideológicas do PT e do PSDB, pelo menos ao nível do discurso, se mantêm. No entanto, as amplas alianças e coalizões formadas por esses partidos desde 1994 tornaram essas posições muito esmaecidas para a grande maioria do eleitorado. Por conta disso, devemos crer que outras variáveis tenham maior peso que a ideologia na definição do voto, ainda que esta não possa ser totalmente desprezada sem uma análise mais acurada da realidade eleitoral brasileira. 
Um aspecto revelador da descrença com relação à ideologia como fator explicativo do voto é a ausência de questões específicas para medi-la na maioria das pesquisas de opinião eleitoral. De todos os bancos de dados de que dispomos, apenas dois, ambos construídos em 2002, contêm perguntas sobre o autoposicionamento ideológico. Nos dados de 1994, 1998 e 2006 não existe essa variável.

No caso de 1998, o problema foi contornado com a utilização de um constructo que media a opinião do eleitor sobre a privatização dos serviços públicos, que - como apontam Almeida \& Young (2002) e Camargo (2005) - está associada ao voto e pode medir duas dimensões ideológicas importantes, o liberalismo e o nacionalismo. Para 2006, a medida utilizada foi a que mais se aproximava de algum tipo de ideologia, o autoritarismo; neste caso, uma opinião a respeito da melhor maneira de combater o crime: oferecer melhores condições sociais ou enrijecer o tratamento dispensado aos criminosos.

Das três medidas utilizadas, o autoposicionamento ideológico é a que apresenta o maior índice de não resposta. Nos dados disponíveis, cerca de um quarto dos eleitores não sabe se posicionar em um contínuo esquerdadireita. Em 1998, cerca de 15\% dos entrevistados não souberam responder a perguntas sobre as privatizações; em 2006, apenas 3\% não responderam à questão sobre o combate ao crime. Isso significa que os modelos para 2002 serão mais restritos, uma vez que consideram apenas os que responderam à pergunta do autoposicionamento.

Em 1998, a maior parcela do eleitorado tinha posições indiferentes com relação às privatizações. A privatização das empresas do Sistema Telebrás era vista mais positivamente por $40 \%$ dos eleitores, e a venda de bancos brasileiros a empresas estrangeiras era considerada negativa por $36 \%$. A opinião sobre a privatização em geral, que é a variável utilizada na análise de regressão, aponta que quase metade do eleitorado era indiferente ao processo em curso. 
Tabela 5: Opiniões sobre privatizações e venda de bancos a estrangeiros em 1998 (em \%)

\begin{tabular}{|l|c|c|c|}
\hline \multirow{2}{*}{ Opinião } & \multicolumn{3}{|c|}{ Assunto } \\
\cline { 2 - 4 } & $\begin{array}{c}\text { Privatização } \\
\text { em geral }\end{array}$ & $\begin{array}{c}\text { Privatização das } \\
\text { telefônicas }\end{array}$ & $\begin{array}{c}\text { Venda de bancos } \\
\text { para estrangeiros }\end{array}$ \\
\hline \hline Negativa & 23,1 & 25,0 & 35,7 \\
\hline Indiferente & 47,8 & 35,2 & 40,1 \\
\hline Positiva & 29,1 & 39,8 & 24,2 \\
\hline Total & $\mathbf{1 0 0 , 0}$ & $\mathbf{1 0 0 , 0}$ & $\mathbf{1 0 0 , 0}$ \\
\hline
\end{tabular}

Fonte: Vox Populi (1998).

O Estudo Eleitoral Brasileiro (Eseb), realizado em 2002, pedia que os eleitores se posicionassem em uma escala esquerda-direita de 10 pontos. Para efeito de análise, essa escala foi reordenada para apenas três pontos. ${ }^{5}$ Assim, dos eleitores que se posicionaram, 33\% colocaram-se à esquerda, $30 \%$ ao centro e $36 \%$ à direita. Esses resultados diferem dos obtidos por Singer (2000), nos quais uma parcela maior de eleitores localizava-se ao centro e à direita do espectro político. Talvez essa "esquerdização" do eleitorado seja decorrente da liderança e da vitória de Lula na campanha eleitoral, mas essa hipótese não será testada aqui.

Tabela 6: Autoposicionamento ideológico em 2002

\begin{tabular}{|l|c|}
\hline Autoposicionamento ideológico & $\%$ \\
\hline \hline Esquerda & 33,4 \\
\hline Centro & 30,4 \\
\hline Direita & 36,2 \\
\hline Total & $\mathbf{1 0 0}$ \\
\hline
\end{tabular}

Fonte: Almeida et al. (2002).

Para 2006, a única medida para ideologia disponível é a opinião do entrevistado a respeito da melhor maneira para combater o crime e a violência. Pouco mais de dois terços dos eleitores (69\%) acreditam que a solução é melhorar a educação e os programas sociais de ajuda aos mais

\footnotetext{
${ }^{5} \mathrm{O}$ Eseb utiliza escalas de 0 até 10 . Em metade dos questionários, o zero é a extrema esquerda e o 10 é a extrema direita; na outra metade, a situação se inverte. Nossa recodificação agrupou os quatro pontos nas extremidades como esquerda ou direita $(0,1,2$, 3 ou $7,8,9,10)$ e os três centrais como centro $(4,5$ e 6$)$.
} 
pobres e pouco menos de um terço (32\%) crê que o melhor caminho é construir mais presídios e tratar os presos com mais rigidez.

Tabela 7: Opinião sobre o combate ao crime e a violência em 2006

\begin{tabular}{|l|c|}
\hline Opinião sobre o combate ao crime e a violência & $\mathbf{\%}$ \\
\hline Melhorar a educação e os programas sociais de ajuda aos mais pobres & 68,5 \\
\hline Construir mais presídios e tratar os presos com mais rigidez & 31,5 \\
\hline Total & $\mathbf{1 0 0}$ \\
\hline
\end{tabular}

Fonte: Analítica Consultoria (2006).

\subsubsection{Modelos de regressão com ideologia}

A hipótese presente em todos os modelos de decisão eleitoral que consideram a ideologia é que esta é significante para explicar o voto. Por um lado, todos os autores que fizeram análises considerando a ideologia mostraram que, de algum modo, está sempre relacionada ao comportamento do eleitor. Por outro lado, o pragmatismo ideológico de PSDB e PT deve ter obscurecido qualquer possível impacto que a ideologia exerça sobre o eleitor. Assim, a ideologia deve ser significante para o voto no PSDB e no PT, mas deve explicar pouco o comportamento.

De fato, o Quadro 27, a seguir, mostra que a probabilidade de voto no PSDB é sempre maior entre os eleitores que apóiam o programa de privatizações, entre os que se situam à direita no espectro político e os que são favoráveis à adoção de medidas mais duras contra os criminosos. Essas diferenças são significantes para as duas primeiras posições, mas não para a terceira. Apesar das diferentes chances observadas entre os grupos de eleitores, a ideologia é uma variável com baixa capacidade explicativa e capacidade preditiva nula. Ou seja, a ideologia importa para o comportamento com relação ao PSDB, mas as diferenças observadas entre os eleitores de diferentes campos ideológicos são muito pequenas para decidir eleições, exceto em cenários muito equilibrados. Os $\mathrm{R}^{2}$ indicam que $\mathrm{o}$ melhor modelo com a ideologia é o do segundo turno de 2002, quando atingiu apenas 0,05.

Para os modelos do PT, a conclusão é exatamente a mesma que para os do PSDB (ver Quadro 28). 
Quadro 27: Modelo de regressão logística para a ocorrência de voto no PSDB - Variáveis ideológicas $\left(^{a}\right)$

\begin{tabular}{|c|c|c|c|c|c|}
\hline & $\begin{array}{c}\text { Modelo } \\
1998\end{array}$ & $\begin{array}{c}\text { Modelo } \\
2002 \\
1^{\circ} \text { turno } \\
\end{array}$ & $\begin{array}{c}\text { Modelo } \\
2002 \\
2^{\circ} \text { turno } \\
\end{array}$ & $\begin{array}{c}\text { Modelo } \\
2006 \\
1^{\circ} \text { turno } \\
\end{array}$ & $\begin{array}{c}\text { Modelo } \\
2006 \\
2^{\circ} \text { turno } \\
\end{array}$ \\
\hline \multicolumn{6}{|l|}{ VARIÁVEIS IDEOLÓGICAS } \\
\hline Apoio à privatização & $\begin{array}{c}1,664(* *) \\
(0,05)\end{array}$ & & & & \\
\hline Autoposição ideológica & & $\begin{array}{c}1,539\left(^{* *}\right) \\
(0,07)\end{array}$ & $\begin{array}{c}1,702\left(^{\star *}\right) \\
(0,07)\end{array}$ & & \\
\hline Combate à violência & & & & $\begin{array}{l}1,142 \\
(0,13)\end{array}$ & $\begin{array}{l}1,101 \\
(0,12)\end{array}$ \\
\hline $\mathrm{R}^{2}$ & 0,04 & 0,03 & 0,05 & 0 & 0 \\
\hline $\mathrm{N}$ & 3.200 & 1.883 & 1.883 & 1.548 & 1.548 \\
\hline $\begin{array}{l}\text { Casos previstos corretamente } \\
\text { Votos no PSDB previstos }\end{array}$ & $66 \%$ & $81 \%$ & $74 \%$ & $79 \%$ & $69 \%$ \\
\hline $\begin{array}{l}\text { corretamente } \\
\text { Previsões de voto no PSDB }\end{array}$ & $0 \%$ & $0 \%$ & $0 \%$ & $0 \%$ & $0 \%$ \\
\hline corretas & $0 \%$ & $0 \%$ & $0 \%$ & $0 \%$ & $0 \%$ \\
\hline Chance na base & $33 \%$ & $19 \%$ & $25 \%$ & $20 \%$ & $30 \%$ \\
\hline
\end{tabular}

Notas: $\left({ }^{a}\right)$ A variável apoio à privatização foi operacionalizada assim: contrário $=-1$, neutro = 0 e favorável = 1; a variável autoposição ideológica foi operacionalizada assim: esquerda $=-1$, centro $=0$ e direita $=1$; a variável combate à violência foi operacionalizada assim: melhorar a educação e ampliar programas sociais $=0$ e endurecer com os criminosos $=1 .\left(^{*}\right) p<0,05$. $(* *) p<0,01$.

Fonte: 1998: Vox Populi (1998); 2002: Almeida et al. (2002); 2006: Analítica Consultoria (2006).

Quadro 28: Modelo de regressão logística para a ocorrência de voto no PT - Variáveis ideológicas $\left({ }^{\mathrm{a}}\right)$

\begin{tabular}{|c|c|c|c|c|c|}
\hline & $\begin{array}{c}\text { Modelo } \\
1998\end{array}$ & $\begin{array}{c}\text { Modelo } \\
2002 \\
1^{\circ} \text { turno }\end{array}$ & $\begin{array}{c}\text { Modelo } \\
2002 \\
2^{\circ} \text { turno }\end{array}$ & $\begin{array}{c}\text { Modelo } \\
2006 \\
1^{\circ} \text { turno }\end{array}$ & $\begin{array}{c}\text { Modelo } \\
20062^{\circ} \\
\text { turno }\end{array}$ \\
\hline \multicolumn{6}{|l|}{ VARIÁVEIS IDEOLÓGICAS } \\
\hline Apoio à privatização & $\begin{array}{c}0,738(* *) \\
(0,06)\end{array}$ & & & & \\
\hline Autoposição ideológica & & $\begin{array}{c}0,618(* *) \\
(0,1)\end{array}$ & $\begin{array}{c}0,595(* *) \\
(0,1)\end{array}$ & & \\
\hline Combate à violência & & & & $\begin{array}{c}0,926 \\
(0,1)\end{array}$ & $\begin{array}{c}0,948 \\
(0,1)\end{array}$ \\
\hline $\mathrm{R}^{2}$ & 0,01 & 0,05 & 0,06 & 0 & 0 \\
\hline $\mathrm{N}$ & 3.200 & 1.883 & 1.883 & 1.548 & 1.548 \\
\hline $\begin{array}{l}\text { Casos previstos corretamente } \\
\text { Votos no PT previstos }\end{array}$ & $75 \%$ & $61 \%$ & $60 \%$ & $51 \%$ & $56 \%$ \\
\hline $\begin{array}{l}\text { corretamente } \\
\text { Previsões de voto no PT }\end{array}$ & $0 \%$ & $36 \%$ & $76 \%$ & $70 \%$ & $100 \%$ \\
\hline corretas & $0 \%$ & $54 \%$ & $62 \%$ & $52 \%$ & $56 \%$ \\
\hline Chance na base & $25 \%$ & $58 \%$ & $71 \%$ & $52 \%$ & $57 \%$ \\
\hline
\end{tabular}

Notas: $\left({ }^{\mathrm{a}}\right)$ A variável apoio à privatização foi operacionalizada assim: contrário $=-1$, neutro $=$ 0 e favorável =1; a variável autoposição ideológica foi operacionalizada assim: esquerda $=-1$, centro $=0$ e direita $=1$; a variável combate à violência foi operacionalizada assim: melhorar a educação e ampliar programas sociais $=0$ e endurecer com os criminosos $\left.=1 .{ }^{*}\right) p<0,05$. $(* *) p<0,01$.

Fonte: 1998: Vox Populi (1998); 2002: Almeida et al. (2002); 2006: Analítica Consultoria (2006).

A ideologia em suas diferentes medidas é significante para o voto no partido, mas as diferenças entre os eleitores de acordo com essas posições 
nos informam muito pouco sobre como deve se comportar o eleitor. Os modelos possuem baixa capacidade explicativa e preditiva. Assim como para o PSDB, o melhor modelo foi o do segundo turno de 2002, quando o R2 atinge 0,06. Ou seja, a ideologia tem relação com o voto, mas ela é muito tênue e não consegue dar conta adequadamente do comportamento eleitoral, especialmente no que diz respeito ao voto no PSDB ou no PT.

\subsection{Combinando variáveis socioeconômicas com político-ideológicas}

Em quase todos os modelos de decisão do voto existe, implícita ou explicitamente, a hipótese de que as condições socioeconômicas influenciam as posições políticas e ideológicas dos eleitores. Essa temática foi analisada no capítulo anterior, quando mostramos que faz pouco sentido falar em bases eleitorais socioeconômicas de PSDB e PT. Também vimos nas seções anteriores deste capítulo que partidos e ideologias estão associados ao voto, mas não conseguem explicar mais que 30\% do comportamento eleitoral, além de ter influência declinante sobre o voto. Agora, resta saber se a consideração simultânea de características sociais, econômicas e políticas altera as conclusões que chegamos até aqui.

Muitos pesquisadores já trataram de analisar quais efeitos as condições sociais e econômicas exercem sobre o comportamento político. Uma das hipóteses mais importantes da escola sócio-psicológica sobre a participação política, em geral, e eleitoral, em particular, é o que se convencionou chamar de modelo de centralidade. As posições são definidas por duas dimensões: a objetiva, definida pelas condições socioeconômicas, como renda, escolaridade ou ocupação; e a subjetiva, ligada ao sentimento de estar no centro dos acontecimentos e ao alargamento do horizonte intelectual-psicológico resultante da maior exposição a informações de todo o tipo. A posição do indivíduo nesse modelo de centralidade define muitos aspectos: quanto mais central, mais informado ele é sobre política, mais participativo, interessado e envolvido no processo político (cf. Pizzorno, 1970, e Reis, 1988). Ademais, 
os indivíduos em posição central são os que apresentam os maiores índices em todos os indicadores de participação eleitoral: mais se envolvem em nas campanhas políticas, mais comparecem para votar, etc.; são também aqueles entre os quais se pode observar grau maior de estruturação ideológica, expressa na relação que fazem entre as opiniões sobre as diversas questões em discussão na arena política e na escolha eleitoral (Castro, 1994, p. 123).

Existe uma idéia generalizada na ciência política brasileira, já apresentada em diversos estudos, de que a consistência ideológica do eleitorado, expressa pelas relações entre as opiniões políticas e com os partidos, só encontra força entre eleitores de melhor condição social, com renda, escolaridade e ocupação mais altas. Os trabalhos sobre as eleições no atual período democrático também adotam essa perspectiva. Castro (1994), por exemplo, defende a tese da centralidade da sofisticação política para o comportamento eleitoral. Segundo esta autora, apenas os mais sofisticados apresentam comportamento previsível de acordo com suas posições políticas e ideológicas, e a sofisticação depende "fundamentalmente da situação social dos indivíduos, em especial do seu grau de escolarização" (Castro, 1994, p. 212).

Em sua principal crítica à tese da identificação ideológica defendida por Singer, Carreirão (2002) procura mostrar que a identificação ideológica e os efeitos que exerce sobre o comportamento eleitoral estão relacionados ao nível de escolaridade. Ele defende que entre os eleitores menos escolarizados o autoposicionamento no contínuo esquerda-direita não guarda associação com o comportamento eleitoral, enquanto que entre os eleitores mais escolarizados a associação é forte e na direção esperada (Carreirão, 2002, p. 110).

Borges (2004) volta-se para os diferentes significados que os eleitores dão às categorias esquerda e direita. Mostra, com apoio de dados de survey com eleitores da Grande São Paulo, que a grande maioria destes não sabe definir o que significam esses conceitos ou thes atribui significados que, do ponto da vista da ciência política, são totalmente equivocados. Segundo o autor, apenas entre os eleitores mais escolarizados existe uma posição ideológica com significado realmente político. 
Outra investigação que utiliza os mesmos dados de pesquisa foi realizada por Pimentel Jr. (2004) e mostra a existência de relação entre conhecimento político e o voto partidário. Os eleitores com alto nível de conhecimento teriam forte propensão a votar partidariamente; já entre os de nível mais baixo a tendência é muito mais personalista. O nível de conhecimento não é definido pela escolaridade, mas, em grande medida, está associado a esta.

Com dados do Eseb, Martins Jr. \& Dantas (2004) criaram um índice de participação político-eleitoral a partir de indicadores de participação social em campanhas eleitorais e informação política. Os resultados sugeriram que o eleitor brasileiro participa muito pouco da política e que a variável mais intensamente associada aos níveis de participação é a escolaridade do eleitor. O índice também está associado ao sexo, à idade e ao pertencimento à população economicamente ativa.

Com relação à identidade partidária, Balbachevski (1992) e Carreirão \& Kinzo (2004) já mostraram que existe uma tendência a se encontrar níveis mais altos de identificação entre os eleitores de escolaridade média.

Kinzo (2005) demonstra que a identificação partidária em geral aumenta com a escolaridade, mas que a diferença entre os grupos é pouco significativa. Considerando-se apenas os dois partidos com mais altos níveis de identificação, esta autora mostra que os petistas tendem a conhecer mais os partidos, a ser mais democráticos, a trabalhar fora e a ser mais escolarizados, enquanto os peemedebistas têm propensão a conhecer mais partidos, a ser menos democráticos e menos escolarizados.

Em suma, diversos autores apontam para a associação entre condições socioeconômicas e posições políticas e ideológicas. O elemento cognitivo, a escolaridade, em particular, é o aspecto central para o qual muitos apontam como responsável maior pelo baixo nível do eleitorado e pela conseqüente baixa inteligibilidade do sistema político. Não obstante, ainda não se sabe como as variáveis de longo prazo atuam conjuntamente em um modelo de decisão de voto. Pelo que vimos até aqui, variáveis socioeconômicas e políticoideológicas deveriam exercer efeitos independentes sobre o comportamento eleitoral. 
2.6.1. Modelos de regressão com o conjunto de variáveis de longo prazo

Os modelos de regressão logística para a ocorrência de voto no PSDB e no PT com o conjunto de covariáveis de longo prazo mostram que, até este ponto da análise, a preferência partidária é o aspecto mais importante para a decisão de voto. Contudo, a cada eleição diminui sua importância e cresce, especialmente em 2006, a importância das características demográficas e socioeconômicas. Também chama a atenção o fato de que a escolaridade não tenha sido significante para a direção do voto ao longo de todo o período.

Para o caso do PSDB, os modelos são semelhantes aos que já foram apresentados (ver Quadro 29, a seguir). Verificam-se tendências de apoio maior entre as mulheres, entre os de maior renda, os brancos, os peessedebistas, peemedebistas e pefelistas e entre os que se posicionam à direita. Contudo, essas tendências não se cristalizam em razões de chance estatisticamente significantes. Os modelos têm $R^{2}$ entre 0,20 e 0,29 , e o percentual de votos no PSDB previstos corretamente nunca ultrapassa 50\%. Em outros termos, apesar da grande quantidade de covariáveis, os modelos de longo prazo explicam pouco e prevêem mal o voto no PSDB.

Aparentemente, o voto presidencial no PT, ao longo do tempo, sofreu transformações maiores que o voto presidencial no PSDB (ver Quadro 30, mais adiante). Em geral, as chances de voto no partido tendem a ser maiores entre os homens, entre os com renda mais baixa, os não brancos, os católicos, os nordestinos, os petistas e os posicionados à esquerda; mas nem sempre as razões de chance são significantes. À medida que o eleitorado do PT cresce, o petismo tem sua força esvaziada, os eleitores que têm preferência pelo partido perdem força na explicação do voto desde 1994 até 2002. 
Quadro 29: Modelo de regressão logística para a ocorrência de voto no PSDB - Conjunto das variáveis de longo prazo

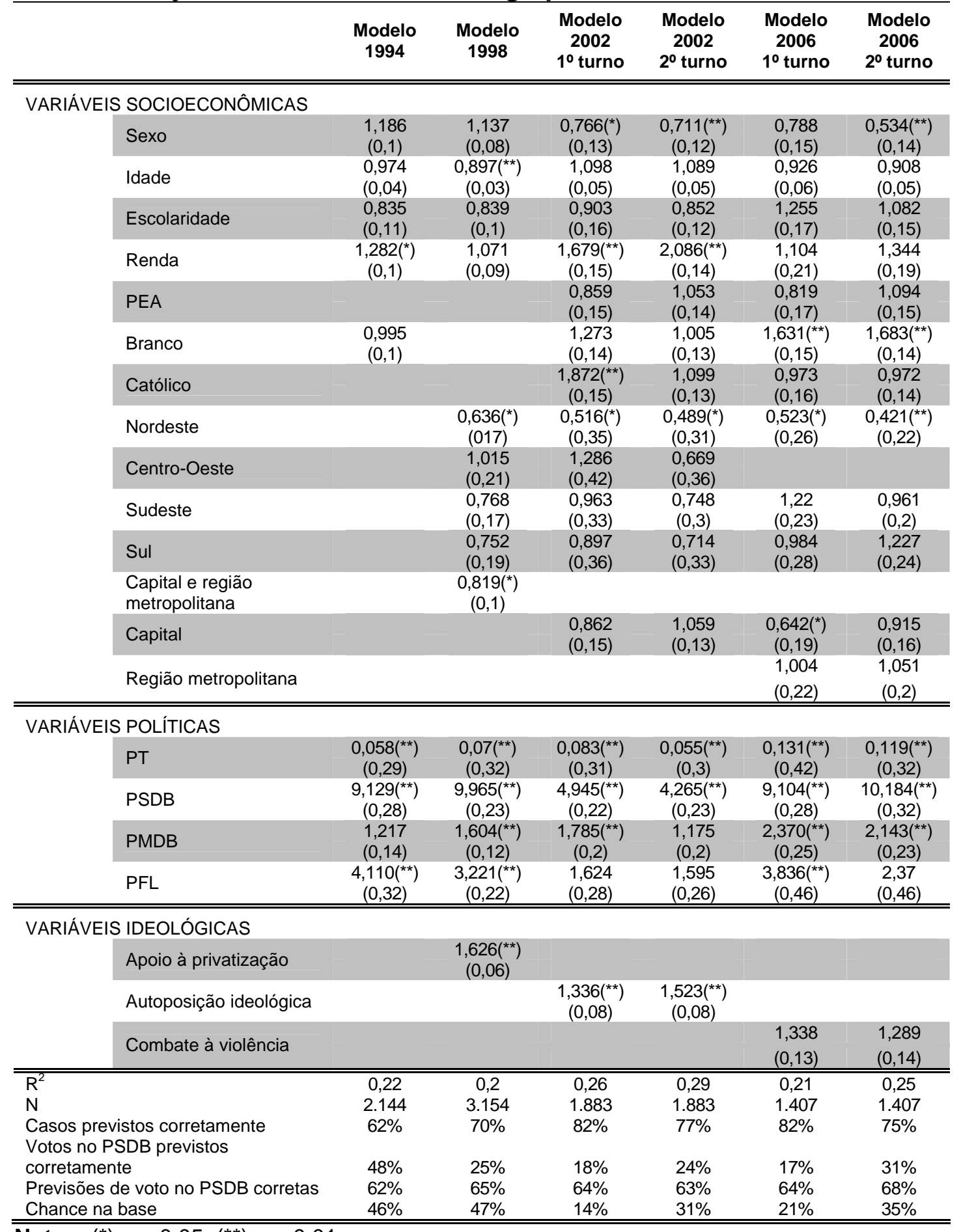

Notas: $\left(^{\star}\right) p<0,05$. $\left(^{* *}\right) p<0,01$.

Fonte: 1994: Datafolha (1994); 1998: Vox Populi (1998); 2002: Almeida et al. (2002); 2006: Analítica Consultoria (2006).

Na eleição de 2006, há certa recuperação do partidarismo, acrescida de uma polarização social inédita. Parece surgir um novo petismo, muito 
diferente do petismo oposicionista. O petismo governista torna-se majoritariamente masculino, não branco, católico e nordestino.

Quadro 30: Modelo de regressão logística para a ocorrência de voto no PT - Conjunto das variáveis de longo prazo

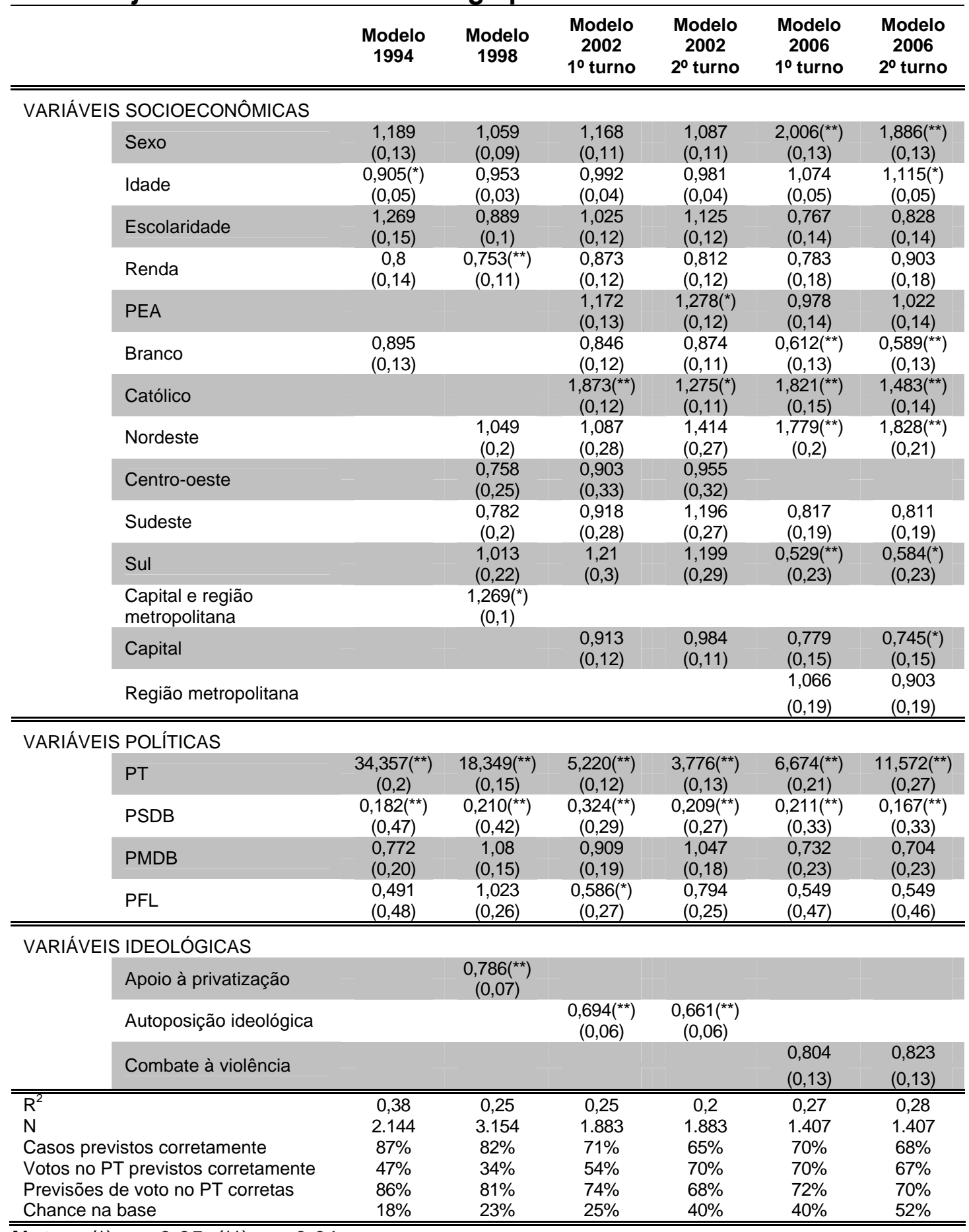

Notas: $\left(^{\star}\right) p<0,05 .\left(^{* \star}\right) p<0,01$.

Fonte: 1994: Datafolha (1994); 1998: Vox Populi (1998); 2002: Almeida et al. (2002); 2006: Analítica Consultoria (2006). 
Esse novo petismo parece ter feito recrudescer diferenças regionais importantes entre o Sul/Sudeste desenvolvido e 0 Norte/Nordeste subdesenvolvido. Também é importante destacar que o voto no partido tem sido independente da escolaridade, do local de moradia e da preferência pelo PMDB e pelo PFL. Dessa maneira, os modelos apresentam $R^{2}$ entre 0,20 e 0,38 e chegam a prever corretamente $70 \%$ dos votos no partido.

\subsection{Considerações finais}

Nos dois primeiros capítulos da tese, procuramos testar as principais hipóteses sobre o comportamento eleitoral que levam em conta aspectos de longo prazo. Verificamos a hipótese de que as características socioeconômicas influenciam o comportamento eleitoral e mostramos que, de maneira geral, explicam muito pouco o voto no PSDB ou no PT nas eleições presidenciais entre 1994 e 2006 - ressalvando que, no último pleito, foram encontrados indícios de maior polarização partidária entre grupos sociais.

Com relação ao partidarismo, nossa hipótese era que sua força seria crescente, uma vez que as contínuas reedições da disputa entre PSDB e PT enrijeceriam as lealdades partidárias. Mostramos que a preferência partidária foi a variável de longo prazo que melhor explicou o comportamento eleitoral, mas sua força tem sido declinante, especialmente com relação aos petistas. Apontá-la como a variável que melhor explicou pode fazer pensar que tenha sido muito importante para o resultado eleitoral, mas não é disso que se trata. $\mathrm{Na}$ verdade, o poder explicativo do partidarismo dificilmente ultrapassa os $25 \%$, mesmo considerando-se medidas mais flexíveis.

Assim como o partidarismo, a ideologia parece ser importante, mas tem âmbito muito restrito. Sem dúvida, as posições ideológicas conduzem a comportamentos eleitorais diversos; essa diversidade, porém, está distante de determinar o resultado eleitoral.

A combinação dos modelos socioeconômico e partidário ideológico eleva a capacidade explicativa para quase 30\% do comportamento eleitoral - o que é muito pouco, considerando-se que foram utilizadas 12 variáveis independentes. Dessa forma, podemos descartar a superioridade de um 
modelo de voto que considere apenas variáveis de longo prazo, não existem bases sólidas de apoio aos partidos nas eleições presidenciais. Isso significa que a explicação para o voto deve ser buscada em aspectos mais conjunturais. O próximo capítulo desta tese irá explorar esses aspectos, principalmente os relacionados aos candidatos presidenciais e às questões presentes na campanha eleitoral. 


\section{Capítulo 3. Modelo racional de decisão de voto}

Até aqui, foram examinadas as variáveis de longo prazo e testadas as principais hipóteses sobre o comportamento eleitoral relacionadas a tais variáveis. Vimos que as características socioeconômicas e políticoideológicas explicam pouco o comportamento eleitoral nas disputas entre PSDB e PT nas eleições presidenciais de 1994 até 2006. Do amplo conjunto de variáveis consideradas, a que se revelou mais importante foi o partidarismo, seja a preferência partidária, seja a avaliação dos partidos. Essa importância não deve ser sobrevalorizada, uma vez que apresenta tendência declinante $\mathrm{e}$ insuficiente capacidade explicativa para fazer compreender por que esses dois partidos se mantêm na liderança da corrida presidencial sem possuir sólidas bases sociais e políticas.

Não surpreende que seja assim. A ausência de tais bases decorre de diversos aspectos, dentre os quais se destacam a fórmula de disputa, que permite a formação de alianças eleitorais, a indiferenciação ideológica (que faz com que os partidos sejam parecidos uns com os outros) e os governos de coalizão (os quais permitem que certos partidos ocupem indefinidamente posições de governo). Esses aspectos dificultam a criação de vínculos, seja de que natureza for, entre os eleitores e os partidos.

As campanhas eleitorais de massa e a primazia dos candidatos fatos que foram e estão sendo vividos em todas as democracias ocidentais consolidadas - exigem que os analistas busquem encontrar novos caminhos de pesquisa que possam indicar com mais precisão como o eleitor decide seu voto. A teoria sobre o comportamento eleitoral que aborda aspectos mais conjunturais, relacionados às questões que permeiam toda campanha eleitoral democrática, ganhou força a partir da publicação, em 1957, da primeira edição original de Teoria econômica da democracia (Downs, 1999). A partir dessa obra, foram estabelecidas novas bases para as pesquisas na área, especialmente aquelas relacionadas a questões políticas, das quais se destacam as avaliações que os eleitores fazem dos governos e dos candidatos. Assim, abriu-se nova vertente de análise a partir da qual as 
características demográficas, socioeconômicas e político-ideológicas não saem de cena, mas perdem em importância para os aspectos conjunturais.

Não faremos aqui uma revisão abrangente dos trabalhos que se destacaram na análise da teoria da escolha racional, apenas daqueles que levantaram aspectos de curto prazo da decisão eleitoral. O objetivo é revisar a literatura internacional e nacional sobre o papel das questões políticas na decisão de voto, a fim de estabelecer um enquadramento mais adequado da problemática, assim como da formulação e dos testes de hipótese que serão apresentados e examinados.

\subsection{Racionalidade na decisão de voto}

Um dos aspectos mais importantes nas análises dos fatores de curto prazo na decisão de voto é a racionalidade do eleitor. Esse aspecto foi um dos que suscitou debates acalorados, especialmente nos EUA, a partir de meados do século XX. Especialmente após o The American Voter (Campbell et al., 1960), muitos analistas apontaram a ausência de estruturação ideológica do eleitorado, e não foram poucos os que afirmaram que a decisão eleitoral poderia ser encarada quase como aleatória. Entretanto, a partir do trabalho de Downs, os pressupostos da racionalidade do voto foram relaxados.

Segundo Downs, para tomar uma decisão de voto racional, todo eleitor precisa estar informado - ou seja, sem informação não existe racionalidade. Quem vota deve saber o que quer, como conseguir o que quer e quais as conseqüências disso. O autor apresenta os sete principais passos para uma decisão racional de como votar: 1) reunir informação relevante a cada questão sobre quais importantes decisões políticas foram ou serão tomadas; 2) para cada questão, selecionar, de toda informação reunida, aquela que será usada na decisão de voto; 3) para cada questão, analisar os fatos selecionados, para chegar a conclusões factuais específicas sobre questões políticas alternativas e suas conseqüências; 4) para cada questão, estimar as conseqüências de todas as políticas prováveis, à luz das metas relevantes; 5) coordenar as apreciações de cada questão numa avaliação líquida de cada partido que concorre na eleição; 6) tomar a decisão do voto, comparando as avaliações líquidas de cada partido e pesando-as para futuras eventualidades; 
7) realmente votar ou se abster. Nesse percurso com tantos passos, convenha-se que é difícil tomar uma decisão de fato racional. No entanto, esses passos e seus custos podem ser transferidos para outrem. Apenas o passo 7 é intransferível, mas Downs pondera que os passos 4,5 e 6 envolvem juízos de valor que podem tornar a delegação irracional.

A quantidade de informação que uma pessoa pode coletar e processar é limitada, mesmo com o auxílio de modernas parafernálias eletrônicas. Isso faz com que seja necessária uma seleção dos dados disponíveis à tomada de decisão. Essa seleção é fundamental, porque determina que tipo de informação pode ser utilizado e porque molda as decisões. Segundo Downs, toda informação é reunida de acordo com certos princípios de seleção, que são

regras empregadas para determinar do que fazer uso e do que não. Pessoas diferentes usam regras diferentes, mas todas devem usar alguma regra até mesmo a seleção aleatória segue uma regra. Portanto, toda informação é, por natureza, tendenciosa porque é uma seleção de dados a partir de uma vasta quantidade existente, dos quais outros poderiam ter sido selecionados (Downs, 1999, p. 231).

O eleitor racional consegue construir seus princípios de seleção por tentativa e erro, buscando os meios, os veículos e os homens de comunicação que esposam dos mesmos princípios que ele.

A quantidade de informação que um eleitor racional deve reunir depende de três fatores principais: do quanto ele está interessado em tomar a decisão correta, da relevância e do custo da informação. A isso se deve acrescentar que os eleitores, para economizar recursos, tendem a utilizar um mecanismo de concentração de atenção em áreas diferenciais de decisão. Estas são áreas nas quais os partidos de oposição contestam o governo, ou áreas em que o governo mudou a política que estava sendo adotada anteriormente, ou áreas com que os governos anteriores não tiveram que lidar e que o atual tem. Com os informantes, as fontes de informação e as áreas de decisão, os eleitores podem construir um sistema pessoal de aquisição de informação. "Para ser racional, esse sistema deveria ter o viés apropriado, estar bem focalizado, fornecer dados adequados, mas não supérfluos e conter alguma pluralidade interna" (Downs, 1999, p. 238). 
Os cidadãos racionais precisam reduzir o custo de adquirir informação. Nenhuma informação deixa de ter custo, e o tempo para assimilá-la é um custo não transferível. Não obstante, existem diversas fontes de informação gratuitas, tais como o governo, os partidos, os grupos de interesse, as empresas de comunicação de massa e entretenimento e outros cidadãos. Exceto por estes últimos, todos são fornecedores especializados, possuindo ampla capacidade de reunir as informações e concentrá-las nas áreas diferenciais de decisão e têm grande interesse em influenciar os rumos eleitorais. Para Downs, a fonte mais provável de dados gratuitos que um homem racional utiliza é o contato pessoal com outros que possuem informações. Essa fonte tem vantagens adicionais com relação às demais, porque esse tipo de contato é mais agradável e possibilita a obtenção mais precisa daquilo que o eleitor busca.

A informação que o eleitor obtém durante uma campanha pode ser acidental ou buscada. No primeiro caso, é um subproduto das atividades nãopolíticas e tem custos muito mais baixos que as informações buscadas. A quantidade de informação gratuita recebida por um cidadão depende de diversos aspectos, dentre os quais a renda, a classe social e até mesmo o tipo de entretenimento. Quanto ao primeiro aspecto, diferentes níveis de renda possibilitam acessos diversos aos canais de informação gratuita; quanto ao segundo, a posição de classe pode ter influência decisiva sobre a natureza dos contatos informais estabelecidos no dia-a-dia, no trabalho ou no lazer; quanto ao último, o eleitor pode se distrair, lendo os cadernos de política dos jornais, ou pode ser obrigado a utilizar os transportes e espaços públicos para as atividades de entretenimento. Esse conjunto de fatores possibilita o recebimento de ampla e múltipla gama de informações gratuitas. Além disso, a quantidade de informações gratuitas depende também do grau em que o eleitor é afetado pelas ações do governo, de forma que, quanto mais afetado, mais informações deve receber.

As informações políticas são úteis para os eleitores nos campos eleitoral e governamental. Ajudam a formar a decisão do voto e permitem a formação de opiniões que podem influenciar as políticas governamentais. No modelo de Downs, o homem racional vota para selecionar o melhor governo possível. Isso 
significa que ele vota porque tem um diferencial partidário, ou seja, prefere um partido aos demais concorrentes. Se o eleitor é indiferente, ou seja, se o diferencial partidário é igual a zero, não é racional investir em informação política.

Downs afirma que a decisão do voto é dinâmica e que deve ser considerada como um processo que ocorre no tempo e com distintos passos - o primeiro é estimar o diferencial partidário, seja por meio das informações gratuitas adquiridas cotidianamente, seja por meio de dados obtidos especificamente para esse fim. Um eleitor racional se interessa apenas pela informação que poderia mudar sua decisão preliminar de voto. Assim, quanto mais apoiar um partido, mais difícil será que adquira informações em quantidade suficiente para mudar de opinião. Já o eleitor indiferente tem mais incentivo para se informar, porque, com pouca informação, pode se decidir, mas é improvável que faça. Downs afirma que ninguém tem incentivo grande para adquirir informação política, o que aumenta a probabilidade de que o eleitor confie exclusivamente no fluxo de informação gratuita que recebe diariamente em suas atividades habituais.

Existem outros motivos racionais que podem levar um homem a adquirir informação política. O mais destacado é o desejo de influenciar as políticas de governo. Os bem informados influenciam mais as políticas que um governo adotará - desde que informem ao governo suas preferências. Isso faz com que o governo ignore a opinião dos cidadãos mal informados. A partir desse ponto, Downs inicia uma análise um tanto pessimista das condições de igualdade política dentro de uma democracia. Para ele, os bem informados estão em posição privilegiada e se tornam influenciadores. O tamanho da influência depende de quanto o influenciador pode arcar com o custo da comunicação. Quem pode mais, influencia mais. O mesmo raciocínio leva-o a afirmar que os produtores sempre serão mais influentes no governo do que os consumidores. Essas deduções downsianas baseiam-se diretamente na sua noção do papel desempenhado pela informação e pela divisão do trabalho na tomada de decisão governamental.

Um autor que desenvolveu o conceito de racionalidade de Downs foi Popkin (1994). A idéia de atalho de informação desenvolvida em seu trabalho Reasoning Voter é derivada do trabalho do autor de Teoria econômica da 
democracia. Para Popkin, o eleitor não tem incentivos para se manter informado todo o tempo sobre o que diz respeito ao governo, à política e às eleições; não tem interesse, tempo e recursos para tanto. Para tentar compensar a falta de informação mais acabada, mais detalhada, o eleitor utiliza atalhos de informação. Para Downs, como vimos, um dos atalhos mais importantes é a ideologia. Esta ajuda a diferenciar os partidos, poupando o eleitor do custo de estar informado sobre uma ampla gama de questões. Para Popkin, os atalhos de informação têm a mesma utilidade que para Downs, qual seja, economizar recursos. Contudo, Popkin desenvolve o conceito em outra linha, deixando de lado a ideologia e apontando que os atalhos utilizados pelos eleitores incorporam as experiências passadas, a vida cotidiana, a mídia e a campanha política. São informações mais simples, básicas, chamadas de "baixa racionalidade", que servem como substitutas de informações mais elaboradas, complexas e, conseqüentemente, mais dispendiosas. O eleitor costuma medir junto a outras pessoas a validade de suas informações, por meio da busca da opinião de outros eleitores que o cercam, seja em casa, seja no trabalho, no lazer ou mesmo na mídia e durante uma campanha eleitoral.

Podem existir diferentes tipos de atalhos informacionais, dependendo da vida cotidiana de cada eleitor, uma vez que as informações adquiridas no dia-a-dia funcionam como atalhos. A maneira como ele utiliza e combina seus diversos atalhos tem peso importante na definição de seu voto, porque são aplicados a seus julgamentos e decisões políticas. Assim como Downs, Popkin afirma que a maior parte da informação que os eleitores usam quando votam é adquirida como subproduto das atividades que desempenham e fazem parte de suas vidas diárias. A mídia é importante, porque as pessoas combinam as informações que adquirem no dia-a-dia com as informações dos meios de comunicação. As pessoas vivem, trabalham, locomovem-se, compram, pagam impostos, utilizam serviços públicos e privados: em todas essas situações, recolhem impressões que são parte integrante e muito importante da composição da decisão de voto.

Existem diversos caminhos para tomar uma decisão de voto racional, o que nada mais é do que tomar a melhor decisão possível com o menor custo. 
Isso significa que o eleitor presta maior atenção apenas aos aspectos mais salientes da disputa eleitoral, em especial aqueles mais diretamente ligados à sua vida privada. Seguramente, esses aspectos envolvem a avaliação de governo e dos candidatos. Essas são as questões políticas de mais baixo custo de obtenção, porque são adquiridas no cotidiano, sem necessidade de investimento específico.

A seguir, são apresentados e analisados os mais importantes trabalhos que trataram dos efeitos dos aspectos de curto prazo sobre a decisão de voto.

\subsubsection{Avaliação de desempenho governamental}

Como já anotamos, Downs considera que, se o eleitor é racional, então vota no partido que, acredita este autor, Ihe proporcionará mais benefícios do que qualquer outro. Os benefícios considerados são os obtidos a partir da atividade governamental, que são definidos como utilidade.

Em um mundo hipotético, com informações completas e sem custo, o eleitor racional votaria de acordo com o seu diferencial partidário, que é o resultado de um calculo em que avalia 1) o fluxo de utilidade que recebeu durante o governo atual, descontando o que imagina que receberia se a oposição estivesse no poder, e 2) o que espera receber caso o governo seja reeleito, descontando o que espera receber caso a oposição vença a eleição. Se o resultado for positivo, vota no governo; se for negativo, vota na oposição; se for zero, se abstém.

O eleitor deve comparar uma renda de utilidade presente real e uma hipotética, ou duas rendas de utilidade futuras hipotéticas. Parece claro que a primeira alternativa é mais plausível e racional, uma vez que o eleitor tem um parâmetro baseado diretamente nos fatos presentes, não em especulações sobre o futuro.

A decisão baseada em fatos presentes não significa que os eleitores ignoram o futuro quando votam. Isso seria irracional, já que o objetivo de votar é selecionar um futuro governo. Dois aspectos importantes auxiliam o eleitor racional a tomar essa decisão. O primeiro está relacionado com os acontecimentos politicamente relevantes ocorridos durante o período eleitoral 
atual. O segundo, com uma comparação entre o que o governo está fazendo e o que o eleitor gostaria de estar recebendo, se o governo que ele julga ideal estivesse no poder. "Cada homem pode usar seu conceito particular de governo ideal para atribuir uma avaliação de desempenho ao partido no governo ou a qualquer outro partido" (Downs, 1999, p. 64).

Os eleitores desenvolvem seus padrões de avaliação de desempenho a partir de suas experiências com outros governos. Essa medida os ajuda a descobrir como os ocupantes dos cargos públicos se saíram em sua tarefa de governar. Na visão de Downs, as avaliações de desempenho são úteis, porque permitem comparar governos que funcionam em períodos de tempo diferentes ou mesmo em áreas diferentes. Para o autor, usam-se as avaliações de desempenho apenas quando os diferenciais partidários atuais são iguais a zero. Isso significa que, antes da abstenção, caso os diferenciais partidários atuais sejam iguais a zero, o eleitor considera a avaliação de desempenho.

Se Downs afirma que o eleitor racional se decide a partir de uma avaliação retrospectiva e prospectiva, Key (1966) reforça em sua análise o conteúdo retrospectivo: o eleitor busca resultados do governo que são observados e medidos a partir do nível de bem-estar conquistado, independente de como ele foi atingido, porque não é capaz de avaliar comparativamente a eficácia de diferentes políticas públicas. Ou seja, o voto é um instrumento racional para punir ou premiar os governos, segundo seu desempenho no período que se encerra no dia da eleição. De forma geral, o trabalho de Key defende a idéia de que bons tempos costumam premiar o governo e dificultar 0 caminho da oposição, e os maus tempos costumam fazer substituir os governos.

O autor também delineou um modelo simples de comportamento político denominado de "teoria da câmara de eco", cujo argumento central é que a decisão de cada pessoa, como integrante do povo, não passa de uma seleção reflexiva dentre as alternativas e possibilidades que the são apresentadas. Vale dizer, o eleitor reage ao que lhe é oferecido, de tal forma que o que sai da "câmara de eco" depende diretamente do que entra. Dessa forma, na visão de Key, as clivagens sociais exercem impacto sobre os resultados eleitorais apenas quando são salientes durante a campanha. 
Fiorina (1981) é um dos principais autores que desenvolveram seus trabalhos à luz do que Downs propôs. Ele buscou integrar, em um mesmo modelo de voto, avaliações retrospectivas e prospectivas, considerando que as avaliações explicam melhor o voto quando comparadas à identificação partidária, especialmente para os mais interessados em política. Este autor distingue dois tipos de avaliação retrospectiva: SRE (simple retrospective evaluation) e MRE (mediated retrospective evaluation). A primeira inclui itens como situação financeira pessoal, negociações externas, direitos civis e outros que parecem refletir experiências diretas ou impressões de eventos e condições políticas. A segunda, itens como avaliação do desempenho presidencial e do desempenho econômico do governo. Para Fiorina, o que faz a mediação da avaliação desses itens são as fontes de informação, as opiniões de lideranças e as predisposições políticas, e o conceito de questão política e as avaliações de candidato podem muito bem ser traduzidos em avaliações retrospectivas e prospectivas.

Seja qual for o tipo de avaliação feita pelo eleitor, é importante porque, segundo Fiorina, o voto retrospectivo está distribuído de forma mais ou menos uniforme entre os diversos níveis de educação, ocupação e informação. Ele pondera que isso pode significar que o julgamento do desempenho da atual administração seja a melhor informação de que qualquer um dispõe no mundo altamente incerto da política e, nessas condições, pode ser utilizado por todos os indivíduos. Também pode simplesmente refletir um tipo de consistência entre desempenho e questões políticas, de forma que o voto baseado em um parece ser também um voto baseado no outro - ou seja, as avaliações de governo e de questões se combinam e se complementam.

\subsubsection{Avaliação de candidatos}

Por muitos motivos, nas décadas recentes, as análises sobre a disputa política nos EUA deixaram de ter como preocupação central a política bipartidária e deram ênfase cada vez maior à disputa que gira em torno dos candidatos. Quando as pesquisas de Colúmbia e Michigan tiveram início, os Partidos Democrata e Republicano eram as mais antigas instituições das 
democracias ocidentais, com uma história centenária e sem interrupções. Para a política dos EUA, a identificação partidária foi importante como em nenhum outro lugar do mundo. Conforme o século XX chegava ao fim, entretanto, os partidos nos EUA perderam muito de seu controle centralizado sobre o processo de nomeação presidencial e perderam muito da lealdade de seus eleitores.

Para compreensão do comportamento eleitoral, saber se a atual política presidencial dos EUA é ou não mais bem caracterizada como concentrada no candidato é menos importante que a atenção mais sistemática que tem recebido o papel exercido pelas avaliações que os eleitores fazem dos candidatos nos modelos de decisão de voto. O fato é que o tema tornou-se mais presente quando os analistas políticos e a mídia adotaram o tema da centralidade do candidato. Os partidos norte-americanos podem até não ter perdido tanta importância para o eleitor, mas claramente desempenham papel menos importante no recrutamento e na promoção dos candidatos a cargos públicos, desde a adoção das eleições primárias e do desenvolvimento de uma indústria de campanhas e eleições independente das organizações partidárias. Recentemente, muitos esforços têm sido feitos para entender o papel das características dos candidatos em um modelo de voto. Esse componente é importante para melhor entender o ato de votar.

No trabalho citado, Key (1966) argumenta que a estrutura do debate político tem papel determinante na maneira como os eleitores avaliam as questões políticas e fazem suas escolhas. Com a fragilidade partidária e a ascensão da mídia, em especial a televisão, a campanha concentrou-se nos candidatos e o debate, agora mais concentrado em questões, encaminhou-se para aspectos de curto prazo. Se os candidatos presidenciais ficam cada vez mais livres dos partidos, tornam-se, conseqüentemente, mais livres para tomar posições diferentes das partidárias e mais visíveis para o eleitorado.

O artigo de Miller, Wattenberg \& Malanchuk (1986) aplica a teoria da cognição social na investigação das dimensões avaliativas dos candidatos utilizada pelos eleitores norte-americanos. Uma descrição empírica das representações cognitivas dos candidatos presidenciais feita pelos eleitores, derivadas de perguntas abertas presentes no American National Election Studies entre 1952 e 1984, revela que as percepções dos candidatos em 
geral se focalizam em características pessoais, mais do que em questões políticas ou filiações partidárias. Diferentemente do que já tinha sido observado, os autores mostram que os eleitores mais educados têm maior probabilidade de utilizar categorias pessoais do que posições em questões como justificativas do voto. Isto é: o voto baseado na personalidade do candidato pode não ser indicador de superficialidade ou de irracionalidade. Os dados examinados pelos autores indicam que as avaliações pessoais refletem critérios relevantes para o desempenho presidencial, tais como competência, integridade e confiança. Estes pesquisadores mostram também que as avaliações pessoais seguem um esquema razoavelmente estruturado, que é aplicado nas ocasiões necessárias. Assim, reinterpretam a idéia da inconsistência de um voto baseado em características pessoais e argumentam que as avaliações desse tipo podem refletir uma representação cognitiva dos candidatos a partir da qual decisões podem ser tomadas.

A presença cada vez mais importante dos candidatos presidenciais nos EUA foi analisada por Wattenberg (1991). Para ele, na medida em que declinavam as forças tendentes a estabilizar o voto, os acadêmicos passaram a prestar mais atenção nas influências econômicas sobre o voto. O autor sugere que uma pergunta derivada do trabalho de Downs - "o que você tem feito por mim ultimamente?" - consegue abarcar um eleitorado mais amplo que nos estudos de Colúmbia, segundo os quais os eleitores votam com seu grupo social, e Michigan, em que a identificação partidária é determinante. Ou seja, o voto econômico passou a ter maior peso que o voto sociológico ou partidário. Wattenberg mostra que, entre 1952 e 1988, a maior parte dos eleitores passou a justificar seu voto presidencial em termos econômicos, enquanto que as justificativas partidárias caíram pela metade. Na eleição presidencial de 1984, nada menos que $60 \%$ dos eleitores deram respostas econômicas como justificativas de voto. Assim, os candidatos presidenciais se tornam cada vez mais suscetíveis aos humores da economia. Em reeleições, o que se espera é um efeito ainda mais forte da vinculação entre estado da economia, avaliação do governo, popularidade do presidente e índices de intenção de voto.

Segundo Miller \& Shanks (1996), forças de curto prazo, em especial as avaliações dos candidatos, exercem alguma ativação temporária nas 
predisposições estáveis e em aspectos da campanha eleitoral. As avaliações de candidatos nascem de considerações a respeito de qualidades pessoais específicas que presumivelmente representam o acúmulo de muitas impressões, positivas e negativas, sobre um candidato. As fontes dessas impressões são os diversos episódios dos últimos anos, que envolvem governo e oposição, e a campanha eleitoral em curso, em que aspectos relevantes dos candidatos tornam-se visíveis para os eleitores (cf. Miller \& Shanks, 1996, p. 416).

Com relação às questões políticas, os autores as distinguem em dois principais tipos, as conflitivas e as consensuais. No primeiro tipo, as impressões dos eleitores baseiam-se em uma oposição entre o certo e o errado, ou seja, se o candidato tem a proposta certa ou errada para a questão; no outro, o que importa para o eleitor é o sucesso ou o fracasso do candidato ou do partido no tratamento da questão. Um dos principais focos de análise recai sobre a opinião dos eleitores com relação aos principais problemas do país e seus efeitos eleitorais. Miller \& Shanks destacam que avaliações sobre áreas das políticas públicas que são consensuais estão claramente relacionadas com o voto, mesmo quando controladas pela avaliação partidária, e só perdem capacidade explicativa quando as avaliações das qualidades do presidente entram no modelo. Ao fim, parece não restar muitas dúvidas de que a avaliação das qualidades do presidente ganhou muito peso na definição do voto.

As avaliações de governo e de candidatos devem estar mais fortemente vinculadas em reeleições, quando as características do governo podem se confundir com as do candidato-presidente. De qualquer forma, os autores afirmam que decisões de voto baseadas em avaliações de governo e de candidatos são decisões racionais, uma vez que os eleitores retiram as informações necessárias para esses julgamentos de suas vidas cotidianas e as aplicam em suas decisões políticas de forma coerente e previsível.

\subsubsection{Avaliação de questões}

O voto baseado em questões tem sido um dos objetos de pesquisa mais importante na ciência política dos EUA. Há décadas a dimensão do efeito das questões sobre as escolhas eleitorais é motivo de debate. Isso se 
torna ainda mais importante em um cenário político em que os candidatos presidenciais têm proeminência sobre o partido. Como vimos, o capital político de um presidenciável baseia-se atualmente mais sobre suas qualidades pessoais do que sobre seu partido. Da mesma maneira, as questões políticas passam a desempenhar papel independente dos partidos e se tornam centrais para o voto.

Um aspecto relevante apontado por Downs com relação às estratégias governamentais está relacionado à importância política das maiorias apaixonadas, que prevalece se existe algum consenso na sociedade, seja de intensidade, seja de opiniões. Segundo o autor, um consenso de intensidade ocorre quando a maioria dos cidadãos concorda em relação a quais questões são muito importantes, mesmo que discorde quanto a que política seguir em relação a essas questões; isto é, o eleitor importa-se muito quanto à adoção da política correta, embora possa ter idéias diferentes sobre quais sejam as políticas corretas. Já um consenso de opiniões ocorre quando, em relação a qualquer questão, uma maioria apóia uma alternativa mais que outras, ou seja, tem a mesma opinião sobre qual política é correta (cf. Downs, 1999, p. 87). O regime de maioria apaixonada tem expressivas repercussões sobre as posições políticas assumidas pelos partidos no governo e na oposição. Assim, a democracia leva à preponderância das opiniões da maioria sempre que os integrantes desta concordam mais do que discordam entre si - da mesma forma que os partidos tendem a convergir sempre que existe algum tipo de consenso sobre alguma questão.

Basicamente, os dois tipos de consensos apontados por Downs estão associados às questões centrais no debate público, capaz de informar minimamente a maioria dos cidadãos. Entretanto, o baixo grau de informação dos eleitores sobre as especificidades das políticas públicas faz com que os consensos de intensidade, formados em torno de questões amplas, sejam mais importantes para a decisão de voto.

Certamente, o trabalho seminal no que diz respeito às questões políticas é o The American Voter (Campbell et al., 1960). Como já observamos, depois de examinar os partidos, os autores mudam seu foco para o que consideram um objeto político de importância fundamental para o 
comportamento eleitoral. Segundo eles, o comportamento político do cidadão, em alguma medida, afeta o curso da política pública, e as questões da política pública afetam o comportamento político do cidadão. Isso significa dizer que, para os autores de Michigan, as questões políticas deveriam ter peso importante na definição do voto.

Não há dúvida que as questões que surgem no debate eleitoral estão relacionadas aos partidos políticos e que as lealdades partidárias influenciam a formação de atitudes frente a tais questões. Assim, se o seguidor de um partido o vê tomando uma posição com relação a uma questão política, tende a ser influenciado por essa posição; mas, se tem alguma firme posição com relação a uma questão e vê seu partido conflitar com ela, tende a mudar de partido, como também procurou mostrar Key (1966). Vale ressaltar que essa congruência entre partidos e questões não é tão clara na cabeça do eleitor, e a massa do eleitorado pode encontrar dificuldades em transladar o que pensa sobre as questões políticas para motivações eleitorais.

Os autores reconhecem que o comportamento político é instrumental. Para eles, o ato de votar não é um fim em si mesmo, mas uma escolha de meios para atingir outros fins. É muito freqüente o fato de que esses fins estejam intimamente relacionados a eventos e aspectos da vida cotidiana dos eleitores, que, no âmago, não são políticos, tais como desemprego, inflação e desigualdades econômica e social. Portanto, essas fontes não políticas da decisão do voto não podem ser negligenciadas.

Ainda para aqueles autores, o papel que uma questão política exerce na decisão do voto é limitado por diversos motivos. Raramente uma única questão consegue prevalecer, na decisão do voto, sobre partidos e candidatos; estes reúnem em si posições com relação a inúmeras questões e têm suas características próprias. No The American Voter são apresentadas três condições que devem ser satisfeitas para que uma questão possa influenciar o voto de um cidadão: 1) a questão precisa ser conhecida de alguma forma, 2) deve suscitar algum sentimento e 3) precisa ser acompanhada da percepção de que um candidato ou partido representa melhor a posição do eleitor do que outros candidatos e partidos. 
Sem dúvida, essas condições limitam muito a extensão das questões como importantes para o comportamento eleitoral. A primeira condição está relacionada à familiaridade dos eleitores com as questões. $O$ termo familiaridade refere-se apenas à existência de uma opinião com algum tipo de significado político. Os autores mostram que questões importantes no debate público, inclusive nos meios de comunicação de massa, passam despercebidas por parcelas significativas de eleitores e que existe uma relação positiva entre anos de escola e familiaridade com as questões.

A segunda condição está relacionada à intensidade das opiniões com relação às questões. Uma questão que não desperta mais que sentimentos difusos entre os eleitores não é politicamente relevante. Claramente, familiaridade e intensidade não são termos intercambiáveis. O primeiro termo traduz o fato de alguém possuir ou não certo tipo de qualidade na opinião com relação a uma questão. As qualidades que definem a familiaridade são a compreensão da questão e a de sua relevância política. O segundo é definido no contexto do primeiro, uma vez que apenas entre os que apresentam familiaridade com alguma questão pode-se observar sua intensidade. Em poucas palavras, o primeiro é cognição e o segundo é avaliação. A diferença observada na intensidade das opiniões sobre as questões está relacionada aos valores que as pessoas Ihes atribuem. Isso significa dizer que valores mais importantes despertam opiniões com maior intensidade.

A terceira condição aponta que as questões seriam irrelevantes para a decisão de voto se as pessoas não conseguissem identificar diferenças entre as políticas dos partidos sobre tais questões. Em muitos casos, as posições dos partidos são ambíguas, diferentes lideranças fazem pronunciamentos contraditórios sobre o mesmo tema, e a distância entre as posições dos partidos sempre varia através do tempo.

De acordo com os pesquisadores, na maioria das questões, menos de um terço dos eleitores preenche as essas três condições, situação reveladora de que geralmente não é clara para os eleitores a identificação entre as questões importantes e divisoras e os partidos e/ou candidatos. Uma das conclusões dos autores é que a articulação entre o programa partidário, as opiniões dos membros do partido e a decisão política individual é fraca. 
Muitas pessoas desconhecem a existência das questões; se conhecem, não estão envolvidas com essas questões; e, se estão envolvidas, não sabem quais são os posicionamentos de partidos e candidatos em relação a elas.

Essa situação decorre de diversos fatores, dentre os quais se destacam as diversas facetas dos partidos políticos, que podem adotar posturas distintas nos âmbitos municipal, estadual e federal, além de divergências internas entre as principais lideranças sobre quais rumos devem ser seguidos. Poucas questões são consensuais no interior de uma legenda partidária. Isso torna importante investigar qual é a posição frente às questões adotadas pelos candidatos à Presidência. Essas pessoas são as que têm maior visibilidade durante as campanhas e personificam os partidos para os eleitores.

Não raramente, os eleitores podem estar muito familiarizados com uma questão específica, podem saber as posições dos partidos em relação a elas, mas podem estar completamente alienados em relação a outras questões. Um exemplo disso pode ser o eleitor que utiliza o transporte público em seus deslocamentos diários para o trabalho, mas não recorre aos serviços públicos de saúde. Ele pode conhecer profundamente os problemas do transporte, mas pode não saber nada do que acontece no interior de um hospital público, porque isso está fora do seu foco de análise.

Poucos dos cidadãos entrevistados na pesquisa de Campbell et al. (1960) mostraram conhecer as posições dos partidos com relação às questões políticas. Mesmo entre aqueles familiarizados com as políticas, os autores encontraram escassa convergência sobre as posições que os partidos adotam. Isso espelharia a similitude das posições dos partidos em diversas questões, assim como a amplitude de opiniões dentro dos partidos. Também mostraria que até cidadãos relativamente informados prestam pouca atenção à formação de políticas públicas específicas. Disso resulta que quase todo o eleitorado não tem informação sobre a tomada de decisões governamentais.

A qualidade com que o eleitorado consegue acompanhar a formulação de políticas públicas tem duas conseqüências correlatas. Primeiro, implica que a decisão do eleitorado será tipicamente ambígua sobre quais atos específicos o governo deveria tomar. Segundo, acarreta que os formuladores das políticas públicas gozam de ampla liberdade para tomar suas decisões. É 
óbvio que os formuladores sofrem pressões emanadas de grupos organizados limitados, porém influentes, dada a ausência de participação de um público mais amplo na tomada de decisões.

Um outro estudo importante nessa linha de análise é o livro The Responsible Electorate, de V. O. Key, Jr. (1966). Com dados de pesquisa do Gallup e do National Opinion Research Center, o autor procura mostrar que o voto estava longe de ser independente das questões políticas. Os eleitores tendiam a votar nos candidatos presidenciais cujos partidos adotavam posições semelhantes às suas nas questões mais importantes suscitadas durante a campanha eleitoral.

Com relação à vitória republicana em 1952, com o general Dwigth Eisenhower, Key afirma que sua vitória deu-se a partir da formação de uma maioria reunida em torno de questões políticas diferentes das que haviam predominado nas eleições anteriores. Nas cinco vitórias democratas desde 1932, haviam sido construídas maiorias em torno de questões econômicas de âmbito doméstico, que muitas vezes envolviam as relações entre capital e trabalho, nas quais os republicanos estavam em desvantagem. Em 1952, as questões de política internacional tornaram-se mais importantes e o candidato presidencial do Partido Republicano parecia aos olhos do eleitorado mais capaz de fazer um bom trabalho nessa área. A maioria formada em torno dessa nova questão exibia um perfil socioeconômico muito mais heterogêneo, porque atraia igualmente eleitores de todos os estratos.

Depois do estudo Key, foi publicada uma série de trabalhos sobre o voto baseado em questões. Muitos — dentre os quais Nie et al. (1981), Pomper (1988) e RePass (1971) - procuram avançar teórica e metodologicamente sobre a temática. Pomper mostra que, entre 1956 e 1968, aumentou consideravelmente a correlação entre a identificação partidária e a opinião em questões políticas relacionadas às eleições presidenciais e que, além disso, cresceu muito a percepção dos eleitores com relação às diferentes posições adotados por democratas e republicanos. RePass procura demonstrar que, quando as atitudes dos eleitores com relação a diferentes questões importantes apontam na direção de um partido, eles votam nesse partido independentemente de sua preferência partidária. Este autor afirma que 
"questões importantes têm quase o mesmo peso que a identificação partidária na previsão da escolha partidária" (RePass, 1971, p. 400).

Em The Changing American Voter, Nie et al. procuraram identificar e interpretar as principais mudanças ocorridas nas características dos eleitores dos EUA entre 1952 e 1972. Entre essas mudanças, eles localizam o declínio do partidarismo; o aumento do número de eleitores que conceitualizam a política, avaliam os candidatos e partidos a partir de critérios ideológicos ou sofisticados; o aumento no nível de força e abrangência da consistência com relação às questões políticas; o aumento do voto baseado em questão, com os eleitores crescentemente utilizando suas posições com relação a questões para avaliar os candidatos; e o aumento da polarização partidária em torno de questões.

O aumento nos níveis de conceitualização do eleitor dos EUA apontada por Nie et al. foi interpretado a partir de uma hipótese ambientalista, na qual o contexto político-eleitoral exerce impacto considerável sobre os eleitores. As eleições presidenciais nos EUA, entre 1964 e 1972, apresentaram debates marcadamente mais ideológicos do que os das décadas anteriores, exatamente pela presença de candidatos e de questões políticas marcadamente mais ideológicas.

Margolis (1977) procura enfatizar que esses autores - Nie et al. (1981), Pomper (1988) e RePass (1971) - afrouxaram demais as condições do voto por questão estabelecida no The American Voter, assim como também avançaram demais em suas análises. Retomando os dados utilizados por RePass, Margolis mostra que o partidarismo expresso por posições em questões políticas conta apenas 5\% na variância observada na decisão de voto. Em geral, a relevância do voto baseado em questões políticas é dependente do contexto eleitoral. O surgimento de novas questões ou de novas posições a respeito de antigas questões, a importância desempenhada pela mídia e as posições políticas dos candidatos seriam os desencadeadores da aparente mudança observada entre os eleitores.

Com relação às questões políticas, Fiorina (1981) discute outro aspecto importante, que é a distinção, já presente em Stokes (1966), entre as de valência e de posição. As questões de posição são aquelas em que o governo defende uma ação dentre um conjunto de ações alternativas 
possíveis definidas pela distribuição das preferências dos eleitores; já as questões de valência são aquelas que apenas ligam os partidos com alguma posição que pode ser positiva ou negativamente avaliada pelos eleitores. Para Stokes (1966), as questões de valência mais importantes e que têm papel importante na decisão de voto nos EUA são as que envolvem depressão e recuperação econômica, guerra e paz, e corrupção. A economia é a questão de valência principal. Não existe uma distribuição de preferências; todos os cidadãos querem que a economia vá bem. Fiorina acredita que o grupo das questões de valência é menor que o das de posição, e que mesmo as de valência, como a boa economia, podem ter meios que conduzem a diferentes tipos de consenso.

As questões políticas, na visão de Fiorina, têm a ver com aquilo sobre o qual os partidos e candidatos discordam durante uma campanha. Isso é central, porque os aspectos mais importantes para análise são aqueles que dividem candidatos, partidos e eleitores. Uma questão que é indiferente para estes três deve ser indiferente para a definição do voto. Além disso, um julgamento feito retrospectivamente sobre uma situação ou resultado anterior é uma questão e, freqüentemente, as características pessoais dos candidatos podem ser questões. Mais habitualmente, uma questão diz respeito a aspectos específicos das políticas públicas, leis e programas, cuja preocupação pode ser tanto retrospectiva, quanto prospectiva. Vale destacar que o conceito de questão não aparece diretamente no modelo proposto por Fiorina. Nele, o que é comumente chamado de questão se divide entre avaliações retrospectivas e expectativas futuras.

Como vimos, foram muitas as pesquisas desenvolvidas nos EUA a partir de um conceito flexível de racionalidade. Muitos autores perceberam que não era possível exigir demais do eleitor. O cidadão nas democracias contemporâneas está muito distante do cidadão desejado pelos cientistas políticos, que muitas vezes Ihe atribuem certas qualidades racionais absolutamente irrealistas. Em outras palavras, o cidadão comum não é sofisticado ou informado e não possui padrão logicamente estruturado de decisão política em torno de ideologias ou de visões de mundo claras e cognitivamente coerentes. As pesquisas mostram que são poucos os eleitores assim. 
Normalmente, para o cidadão comum, é a própria vida cotidiana que determina a avaliação que faz do contexto eleitoral, do governo que encerra seu mandato, dos candidatos que se apresentam à disputa e das questões políticas que norteiam o debate, em especial aquelas em que os candidatos parecem ser diferentes. Em conseqüência, essa visão, que muitas vezes não é firme nem clara, exerce papel importante na tomada de decisão que ele irá adotar nas urnas.

De maneira geral, os eleitores são distantes da política e tendem a basear seus votos em atalhos de informação. No passado, esses atalhos estavam mais relacionados às ideologias e aos partidos, que refletiam clivagens socioeconômicas. Entretanto, tais clivagens enfraqueceram-se, e os partidos e as ideologias também, o que abriu espaço para outro tipo de decisão eleitoral.

No que diz respeito ao papel exercido pelas avaliações de governo, candidatos e questões, a principal distinção entre os EUA e o Brasil é que lá os partidos políticos foram centrais e ainda mantêm patamares consideráveis de identificação partidária que influenciam as avaliações; enquanto que, aqui, do ponto de vista dos eleitores, os partidos nunca foram centrais nas disputas eleitorais e não fazem a mediação entre as avaliações e o voto. Isso tem impactos consideráveis na maneira como os analistas brasileiros trataram dos aspectos relacionados à racionalidade do eleitor.

\subsection{Racionalidade e fatores de curto prazo na decisão de voto no Brasil}

No Brasil, a primeiro trabalho importante que adotou a perspectiva downsiana da racionalidade foi o de Figueiredo (1991). Este autor estuda como as diferentes escolas do comportamento eleitoral trataram a questão da participação eleitoral, procurando demarcar claramente as diferenças de abordagem entre elas. Por um lado, as interpretações sociológicas e psicológicas, que "não permitem captar as motivações que estão por trás das decisões políticas dos indivíduos" (Figueiredo, 1991, p. 192); por outro, a teoria da escolha racional, que busca "entender qual o significado político dos resultados agregados de decisões individuais" (Figueiredo, 1991, p. 143). A opção do autor é francamente pela abordagem da teoria racional. Ele rejeita 
as análises apoiadas na teoria sócio-psicológica, afirmando que conceitos caros a esta, como marginalidade subjetiva, falsa consciência, dever cívico, alienação, emoção e sofisticação - enfim, problemas ou qualidades de qualquer espécie —, servem apenas para descrever uma realidade política, não para explicá-la.

Segundo ele,

o cálculo racional que um eleitor pode fazer não é necessariamente o mesmo em eleições para cargos executivos, no regime presidencialista, ou para o parlamento, no regime parlamentarista. No tocante às eleições locais, regionais ou nacionais, a situação decisória também se altera (Figueiredo, 1991, p. 122).

Com isso, busca destacar que as decisões sempre são tomadas contextualmente. Ou seja: são sempre condicionais, dependem do cenário, do ambiente em que estão inseridas. Nessas condições, a teoria da escolha racional espera que "sob as mesmas condições os indivíduos tomem exatamente as mesmas decisões. E supõe também que, ao se alterarem as condições - 0 contexto - também se alterem as decisões" (Figueiredo, 1991, p. 122).

Este mesmo autor acredita que a decisão eleitoral é sempre conjuntural e que

as respostas eleitorais populares variam diretamente em função do nível de competitividade política e do ordenamento das preferências políticas individuais, condicionados à expectativa acerca do comportamento dos demais (n-1) eleitores (Figueiredo, 1991, p. 185).

A decisão eleitoral consiste na solução do dilema do eleitor, em que cada eleitor avalia a eficiência do seu ato sob a condição de incerteza sobre o que os demais farão e decide antecipando as decisões dos demais. A participação eleitoral racional é condicionada pela incerteza do jogo eleitoral, de tal forma que, quanto maior a incerteza, maior o incentivo à participação.

Apenas a partir do trabalho de Figueiredo é que se estabelece uma discussão acerca da racionalidade do eleitor no Brasil. Até então, os analistas procuravam sempre destacar as deficiências do eleitorado, Figueiredo sugere que essas deficiências não fazem muita diferença na decisão de voto e 
mostra que, de fato, a direção do voto é independente da "qualidade" do eleitor. Contudo, seu trabalho tem como preocupação central a participação eleitoral, não a direção do voto.

Uma das principais críticas ao trabalho de Figueiredo partiu de Castro (1994). Para a autora, o principal problema da proposta de Figueiredo é que, dada o baixo nível de estruturação ideológica e de baixa informação, "é no mínimo difícil imaginar" (Castro 1994, p. 44) que o eleitor seja capaz de tomar sua decisão do voto a partir de um cálculo complicado, em que pondera as chances de cada candidato e as expectativas com relação ao comportamento dos outros eleitores. Isso não significa que, para ela, os eleitores tenham comportamento irracional, mas que a racionalidade depende da sofisticação. Uma vez que a maioria dos eleitores não é sofisticada, pode-se deduzir que ela não acredita na racionalidade do eleitor ou acredita que está limitada a uma parcela restrita do eleitorado.

Silveira (1996) busca analisar a transição que considera ter ocorrido entre um modelo de decisão do voto em que predominava o clientelismo para um modelo em que o centro é a imagem do candidato, algo que durante a campanha se constitui em uma questão política. Após definir 11 diferentes perfis de eleitores, o autor os enquadra em três tipos: 1) o eleitor não racional tradicional, cujos princípios são a lealdade e a tradição e o caráter é durável e dependente da interação social; 2) o novo eleitor não racional, cujos princípios são a sensibilidade, o gosto e a intuição, o caráter é instável e a decisão é autônoma e individual; e 3) o eleitor racional, cujos princípios são a racionalidade de interesse e de valores, o caráter é instável e a decisão é autônoma e individual. Ele considera que o tipo predominante no Brasil é o eleitor do segundo tipo.

Para Silveira, o novo eleitor não racional não pensa em política nem dispõe de instrumentos e recursos lógicos para avaliar e julgar politicamente os eventos eleitorais, não consegue identificar seus interesses e os interesses relevantes no jogo político nem articular de modo lógico idéias políticas, e não toma suas decisões políticas com base em um corpo estruturado de idéias, propostas e programas. Se o novo eleitor não racional não é tudo isso que o autor descreve, ele busca se amparar politicamente 
naquilo que acredita serem as características e atributos simbólicos mais desejados. As bases mais importantes para a decisão de voto nesse caso são os meios de comunicação de massa, as campanhas e as modificações conjunturais, em que cada candidato tenta trazer o debate para o terreno que considera mais favorável. O novo eleitor não racional só acompanha os acontecimentos eleitorais nos momentos decisivos, e as imagens e informações mais relevantes são captadas principalmente através da mídia e, secundariamente, através de conversas com familiares, amigos e outras pessoas próximas. Os acontecimentos da campanha eleitoral e os fatores conjunturais exercem grande influência.

A partir da leitura da tese de Silveira, surge a pergunta: por que é irracional acompanhar apenas os acontecimentos eleitorais nos momentos decisivos, captar imagens e informações mais relevantes através da mídia e de conversas com familiares, amigos e outras pessoas próximas, e deixar-se influenciar pelos acontecimentos da campanha eleitoral e com os fatores conjunturais? Ao contrário, segundo a teoria da escolha racional tal como proposta por Downs, é exatamente isso que é ser um eleitor racional.

\subsubsection{Avaliação de desempenho e voto presidencial no Brasil}

Em A decisão do voto nas eleições presidenciais brasileiras (Carreirão, 2002), examinam-se as eleições presidenciais de 1989, 1994 e 1998, buscando avaliar as influências que exercem sobre a decisão de voto a avaliação de governo, a avaliação dos candidatos e as imagens que o eleitor forma dos partidos e candidatos. Dentre esses aspectos, as imagens - em termos ideológicos de um contínuo entre esquerda e direita ou em termos da avaliação dos candidatos como representantes de interesses sociais, especialmente de categorias difusas, como o povo ou os trabalhadores têm peso importante, mas com efeitos restritos a camadas diferentes da população. As imagens ideológicas funcionam melhor para os mais escolarizados; as imagens dos candidatos importam mais para os menos escolarizados.

Mais importante que esses dois aspectos são as avaliações de desempenho do governo em exercício e a avaliação das qualidades pessoais 
dos candidatos. Com relação à avaliação de desempenho, o autor observa um efeito crescente dessa variável sobre a decisão de voto nas três eleições focalizadas. A explicação para esse fenômeno é dada pelo aumento da polarização entre o governo e a oposição, por uma mais clara vinculação entre o governo e o seu candidato e pelo grau de importância, para a avaliação geral do candidato governista, do fato dele ser o representante da continuidade do governo em exercício (Carreirão, 2002, p. 207). Ele também afirma que o voto econômico, em que o eleitor tende a votar no governo quando a situação vai bem e na oposição quando a situação vai mal, "foi uma das motivações centrais nas três eleições presidenciais" (Carreirão, 2002, p. 208).

No que se refere à avaliação das qualidades pessoais dos candidatos, ele conclui que os eleitores as consideram também em sua decisão de voto, e que seu peso varia conforme o contexto eleitoral. De qualquer forma, os atributos mais desejáveis em candidatos presidenciais são a experiência administrativa, a honestidade, a sinceridade e a credibilidade, quesitos semelhantes aos que já haviam sido destacados por Miller, Wattenberg \& Malanchuk (1986) e Miller \& Shanks (1996).

O trabalho de Carreirão tem como principal qualidade a tentativa de analisar as eleições presidenciais ao longo do tempo, ressaltando que o voto econômico parece ser a variável mais importante no período. Apesar da grande quantidade de dados à disposição do autor, o livro não apresenta análises multivariadas, o que reduz significativamente o alcance dos seus achados. Ao final, ele não consegue avaliar qual das variáveis tem maior efeito sobre a decisão do voto.

O fato é que a avaliação de governo ainda não foi suficientemente analisada para aferir seu impacto sobre a decisão do voto nas eleições presidenciais. Os dados que serão apresentados mostram que Carreirão (2002) está correto, e a avaliação do governo é excelente para explicar e prever o comportamento eleitoral, especialmente em contextos reeleitorais.

\subsubsection{Avaliação de candidatos e voto presidencial no Brasil}

Existem dois conceitos centrais para a compreensão do comportamento político do brasileiro que estão associados à avaliação dos candidatos. Trata- 
se do populismo e do personalismo. Não se fará aqui a análise desses conceitos, apenas apontaremos seus aspectos mais fundamentais.

O populismo é caracterizado por uma relação direta entre o líder político e a massa eleitoral, sem o vínculo partidário ou com um vínculo apenas instrumental. Um líder populista é aquele que adota um discurso de confronto contra forças ocultas que se opõem ao povo, utilizando categorias destituídas de conteúdo classista, e que tende a conquistar uma parcela marginalizada do eleitorado. Existiram e existem, na América Latina, dúzias de exemplos desse tipo de liderança, cujo principal expoente brasileiro foi Getúlio Vargas.

Como já vimos, os partidos contam pouco na disputa eleitoral, abrindo espaço para uma atuação política personalista por parte dos candidatos. São inúmeros os incentivos institucionais para isso nas regras eleitorais e de financiamento de campanha. No Brasil, mais que em outros países, o que se espera é o predomínio do candidato na campanha eleitoral. Em campanhas presidenciais, é mais freqüente encontrar candidatos fortes ligados a partidos, caso claro de PSDB e PT; muitos candidatos, porém, são dissidentes dos principais partidos, como Ciro Gomes, Cristovam Buarque e Heloísa Helena, além de um claramente outsider, Anthony Garotinho. Por um lado, isso parece indicar que o predomínio de PSDB e PT nas eleições presidenciais não estaria ligado tanto aos partidos, mas aos candidatos; por outro, nenhum dos candidatos dissidentes ou outsiders logrou êxito em alicerçar uma campanha que ameaçasse os candidatos dos dois partidos. Isso nos faz acreditar que, apesar da importância das qualidades pessoais dos candidatos para os eleitores, apenas estas não são suficientes para o sucesso eleitoral, que, em grande medida, depende de uma estrutura partidária ampla e coesa em torno de seu candidato presidencial.

Esta ênfase no personalismo foi o modo como Singer (1990) interpretou a vitória de Collor em 1989. O autor acredita que, naquela eleição presidencial,

um grande contingente de eleitores da última periferia deve ter passado de uma identificação partidária com o antigo partido de oposição, o PMDB, para uma identificação de tipo personalista que em um dado momento apareceu como diagnosticador preciso e como o proponente das soluções mais diretas 
para os graves problemas sociais e econômicos daqueles votantes (Singer, 1990, p. 149).

Em Collor, o autor identificava o renascimento do populismo, nos seus discursos de confronto contra a elite e com seu apoio entre as massas urbanas. Mas também apontava para mecanismos institucionais que dariam margem a esse tipo de fenômeno, especialmente a eleição presidencial solteira. De fato, desde a adoção das eleições casadas em 1994, a disputa não saiu mais do controle dos partidos maiores, aspecto revelador do impacto das regras do jogo sobre seus resultados finais.

A tese de Castro (1994) também atribui peso importante para os candidatos na decisão de voto. Para a autora, apenas uma pequena parcela de eleitores sofisticados vota orientada por opiniões sobre questões políticas diversas e pela preferência partidária baseada em uma visão informada sobre os partidos e os candidatos. A maioria não sofisticada é desinformada e não tem opinião sobre as grandes questões do debate político; ademais, "tende a atribuir a seus candidatos as qualidades as opiniões que mais the agradam" (Castro, 1994, p. 180). Assim, a orientação principal dos não sofisticados, a maioria do eleitorado, seriam as imagens vagas e difusas que eles fariam dos candidatos. Essas imagens não são imprevisíveis ou aleatórias: são baseadas na capacidade que o candidato tem de transmitir uma imagem de defensor dos pobres e dos trabalhadores.

Em artigo já citado de Carreirão \& Barbetta (2004), os autores apresentam uma análise multivariada do comportamento eleitoral, mas apenas com dados de 2002, ou seja, sem a perspectiva temporal, e da Grande São Paulo. No trabalho, a avaliação do governo - a qual, na tese de Carreirão (2002), é apontada como principal variável explicativa para o voto - parece ser menos importante que os sentimentos partidários e as avaliações dos candidatos, em especial quanto à honestidade e à competência administrativa, importantes para todos os concorrentes naquela eleição. A perda de poder explicativo da avaliação de governo na eleição de 2002 não surpreende, quando temos em vista que naquela ocasião não existia uma vinculação clara entre o governo e seu candidato. Durante toda a campanha eleitoral de José Serra, as conquistas e os avanços obtidos 
durante o governo de Fernando Henrique Cardoso foram pouco explorados; o candidato buscou ocupar um espaço próprio, desvinculando sua imagem da do presidente, que teve uma participação muito discreta. Nessas circunstâncias, a avaliação do governo ficou em segundo plano na decisão do voto, e os sentimentos partidários e, principalmente, a avaliação dos candidatos assumiram o primeiro plano.

Análise semelhante a essa foi feita por Almeida (2006), em seu livro sobre a eleição presidencial de 2002. Para ele, a vantagem de Lula sobre Serra foi um fenômeno complexo por várias causalidades. Inicialmente, destaca-se o caráter personalista do voto em 2002, quando, na disputa entre o candidato do governo e o da oposição, o eleitorado fez valer em primeiro lugar as características pessoais dos dois. Para o autor, em reeleições, tal como a de 1998, o voto tende a ser menos personalizado. Todavia, a situação de 2002, quando o candidato presidencial do governo não era o próprio presidente, "era mais racional para o eleitor avaliá-los em bases mais pessoais e menos institucionais" (Almeida, 2006, p. 266).

O trabalho de Almeida é o único que considera em suas análises as questões suscitadas durante a campanha eleitoral. Ele mostra que as opiniões dos eleitores sobre os temas da campanha exerciam influências sobre o comportamento dos eleitores. Isso significa que faz diferença para o comportamento eleitoral saber qual problema enfrentado pelo país o eleitor considera mais importante. No caso da eleição de 2002, os eleitores que consideravam a estabilidade econômica e o combate à inflação aspectos importantes apresentavam menor probabilidade de voto no candidato do PT, enquanto que entre os que se preocupavam com a melhoria da saúde pública e com o combate a fome e à miséria apresentavam maior probabilidade de voto em Lula. Para Almeida, a grande sorte do candidato do PT residiu no fato de que os temas em relação aos quais suas posições eram mais frágeis não dominaram a campanha, como nas eleições anteriores. Ele afirma que, na campanha de 2002, a inflação não foi um tema importante. Isso "contribuiu para a vitória do PT, pois, da mesma maneira como ocorrido nas eleições anteriores, a inflação era o terreno no qual predominava o adversário de Lula, fosse ele FH ou Serra" (Almeida, 2006, p. 266). 
A análise da bibliografia brasileira sobre o tema revela que existe uma lacuna importante com relação à consideração de aspectos de curto prazo na decisão do voto. De todos os trabalhos aqui tratados, o único que apresenta essa preocupação é o trabalho de Carreirão, no qual a avaliação de desempenho aparece como principal variável. Sem dúvida, muito pode ser percorrido, tendo como preocupação central os aspectos de curto prazo da decisão do voto. Temos como certo que o eleitor brasileiro em geral não se preocupa muito com a política, não se identifica partidariamente e é inconsistente ideologicamente. Assim, devemos buscar outras respostas, mais ligadas aos aspectos suscitados durante a campanha e mais relacionados à vida cotidiana do eleitor, para aumentar o poder explicativo de um modelo de comportamento eleitoral e para os modelos de decisão de voto entre PSDB e PT.

O pressuposto desta tese é o da racionalidade do eleitor. Não a racionalidade no sentido da escola sócio-psicológica que exige demais do eleitor, mas a racionalidade downsiana, reforçada por Popkin, que relaxa as condições. A teoria da escolha racional defende que é o dia-a-dia do eleitor que condiciona quais questões são importantes para ele, qual é a avaliação que faz dos candidatos frente a essas questões, quanto de informação é necessário para tomar a decisão e quais são os outros eleitores com os quais procurará checar a qualidade das informações e da decisão de voto tomada. Não é preciso alto grau de sofisticação ou de cognição, menos ainda perder muito tempo para fazer esse raciocínio, uma vez que a campanha é curta e o horário gratuito de propaganda eleitoral (HGPE) dura atualmente apenas seis semanas.

Será nesse veio de análise que essa tese buscará propor e testar sua principal hipótese que é a da superioridade explicativa dos aspectos de curto prazo sobre os de longo prazo sobre a decisão do voto.

\subsection{Análise do impacto das avaliações de governo nas eleições presidenciais brasileiras}

A Tabela 8 apresenta dados referentes à avaliação do governo durante as campanhas eleitorais de 1994 até 2006. O primeiro aspecto a ser 
considerado é a ausência, nos bancos de dados utilizados nesta tese, de resultados de perguntas únicas sobre o assunto.

Tabela 8: Avaliação de desempenho do governo nas campanhas de 1994 a $2006(\mathrm{em} \%)^{1}$

\begin{tabular}{|l|c|c|c|c|c|c|c|c|c|c|c|}
\hline \multirow{2}{*}{$\begin{array}{c}\text { Avaliação de } \\
\text { governo }\end{array}$} & $\mathbf{1 9 9 4}$ & \multicolumn{3}{|c|}{$\mathbf{1 9 9 8}$} & \multicolumn{4}{c|}{ 2002 } & \multicolumn{3}{|c|}{ 2006 } \\
\hline \hline Positiva & 78 & r2 & r5 & r7 & r1 & r6 & r8 & eseb & r1 & r3 & r6 \\
\hline Neutra & 13 & 40 & 45 & 22 & 22 & 20 & 41 & 40 & 44 & 51 \\
\hline Negativa & 9 & 27 & 18 & 17 & 38 & 37 & 46 & 45 & 20 & 20 & 11 \\
\hline
\end{tabular}

Fonte: 1994: Datafolha (1994); 1998: Vox Populi (1998); 2002: Almeida et al. (2002) e Ipsos Opinion (2002); 2006: Analítica Consultoria (2006).

Em 1994, a única pergunta disponível é sobre a avaliação do eleitor sobre o Plano Real. Nesse caso, a grande maioria dos eleitores (78\%) avalia o impacto do Plano como positivo para o país, enquanto apenas 9\% exprimiram avaliação negativa. A avaliação do Plano é uma boa aproximação da avaliação do governo em geral, uma vez que grande parte da avaliação de um governo pode ser creditada ao seu desempenho na condução da economia — de forma que, se a economia vai bem, o governo também deve ir bem.

Nas rodadas de pesquisas realizadas pelo Vox Populi em 1998 que continham a pergunta sobre o desempenho do presidente Fernando Henrique Cardoso à frente do governo, o principal aspecto a ser destacado é o aumento do índice de eleitores que o avaliaram positivamente. Na rodada 2, realizada em maio de 1998, portanto antes do início da campanha eleitoral, apenas 30\% dos eleitores fizeram avaliação positiva do governo, percentual

\footnotetext{
${ }^{1}$ Perguntas: 1994: Você acha que o plano Real está sendo bom ou ruim para o país? 1998: Como você avalia o desempenho do Presidente Fernando Henrique Cardoso: está sendo ótimo, bom, regular, ruim ou péssimo? 2002/Eseb: Na sua opinião, de uma maneira geral o Governo Fernando Henrique nos últimos 4 anos foi ótimo, bom, ruim ou péssimo? Nesse caso, a resposta regular era espontânea. 2002/Ipsos Opinion Rodada 1: Como o(a) Sr.(a) avaliaria a administração do Presidente Fernando Henrique Cardoso até o momento, diria que vem sendo: ótima, boa, regular, ruim ou péssima? 2002/Pergunta Ipsos Opinion Rodadas 6 e 8: E que nota, de zero a dez, o(a) Sr.(a) daria aos últimos 3 anos e meio da administração do Presidente, depois da reeleição? Nesse caso as notas de 0 a 3=negativo; de 4 a 6= neutro; e de 7 a 10=positivo. 2006/Analítica Consultoria: E como o(a) Sr.(a) acha que o governo de Lula foi até hoje: ótimo, bom, regular pra bom, regular pra ruim, ruim ou péssimo?
} 
que passa para 40\% em agosto de 1998 e atinge 45\% em setembro. O crescimento da avaliação positiva se dá às expensas das avaliações neutras e negativas, que caem durante o período eleitoral.

Em 2002, observam-se três formulações diferentes para as quatro pesquisas que contém perguntas sobre a avaliação do governo. Como se pode observar na Tabela 8, as diferentes formulações conduziram resultados diferentes, especialmente quando comparamos os resultados da Ipsos Opinion com os do Eseb. O baixo índice de avaliações neutras do Eseb decorre da ausência do estimulo ao eleitor para essa posição. De qualquer forma, o aspecto mais importante a ser destacado nessa eleição são os patamares elevados de avaliações negativas. Com efeito, de todas as pesquisas de que dispomos, a avaliação do governo em 2002 é a pior observada, além de apresentar tendência crescente, ao contrário do que se observou nas eleições de 1998 e 2006 . Talvez isso possa ser explicado pela ausência, durante a campanha, de algum candidato com perfil claramente governista, que apresentasse e defendesse as realizações do governo que encerrava seu ciclo.

Em 2006, observa-se o mesmo padrão que em 1998, qual seja, o de crescimento nos índices de avaliação positiva. De fato, a avaliação do governo Lula passa de $40 \%$ em junho, antes do início da campanha oficial, para 55\% em outubro, antes da realização do segundo turno da eleição.

Os dados de 1998 e 2006 mostram que, até aqui, existe uma tendência clara de aumento nas avaliações positivas do governo durante a campanha eleitoral quando há um candidato à reeleição. Tanto Fernando Henrique, como Lula procuraram, durante a campanha, reforçar suas conquistas e seus avanços e ocultar suas deficiências. Os índices de avaliação de desempenho revelam que ambos foram bem-sucedidos.

\subsubsection{Modelos de regressão com avaliação de governo}

A análise do impacto da avaliação do governo sobre as intenções de voto com a utilização de modelos de regressão logística revela que essa variável é central para o comportamento eleitoral. Tanto para o PSDB, como 
para o PT, as diferenças entre as chances de voto segundo a avaliação do governo são significantes. Também nos dois casos, os modelos são melhores nos anos em que ocorreram reeleições.

Quadro 31: Modelo de regressão logística para a ocorrência de voto no PSDB - Avaliação de governo $\left({ }^{a}\right)$

\begin{tabular}{|c|c|c|c|c|c|c|}
\hline & $\begin{array}{l}\text { Modelo } \\
1994\end{array}$ & $\begin{array}{l}\text { Modelo } \\
1998\end{array}$ & $\begin{array}{c}\text { Modelo } \\
2002 \\
1^{\circ} \text { turno }\end{array}$ & $\begin{array}{c}\text { Modelo } \\
2002 \\
2^{\circ} \text { turno }\end{array}$ & $\begin{array}{c}\text { Modelo } \\
2006 \\
1^{\circ} \text { turno }\end{array}$ & $\begin{array}{c}\text { Modelo } \\
2006 \\
2^{\circ} \text { turno }\end{array}$ \\
\hline \multicolumn{7}{|c|}{ AVALIAÇÃO DE GOVERNO } \\
\hline $\begin{array}{l}\text { Avaliação de } \\
\text { governo }\end{array}$ & $\begin{array}{c}3,264(* *) \\
(0,09) \\
\end{array}$ & $\begin{array}{c}7,276(* \star) \\
(0,08)\end{array}$ & $\begin{array}{c}1,989(* *) \\
(0,06) \\
\end{array}$ & $\begin{array}{c}1,861(* *) \\
(0,05) \\
\end{array}$ & $\begin{array}{c}0,274(* \star) \\
(0,09)\end{array}$ & $\begin{array}{c}0,118(* *) \\
(0,09)\end{array}$ \\
\hline $\mathrm{R}^{2}$ & 0,13 & 0,38 & 0,09 & 0,08 & 0,21 & 0,4 \\
\hline $\begin{array}{l}\mathrm{N} \\
\text { Casos previstos }\end{array}$ & 2.446 & 3.152 & 2.462 & 2.462 & 1.600 & 2.400 \\
\hline $\begin{array}{l}\text { corretamente } \\
\text { Votos no PSDB previstos }\end{array}$ & $61 \%$ & $76 \%$ & $81 \%$ & $75 \%$ & $79 \%$ & $76 \%$ \\
\hline $\begin{array}{l}\text { corretamente } \\
\text { Previsões de voto no }\end{array}$ & $91 \%$ & $68 \%$ & $0 \%$ & $0 \%$ & $0 \%$ & $83 \%$ \\
\hline PSDB corretas & $56 \%$ & $74 \%$ & $0 \%$ & $0 \%$ & $0 \%$ & $63 \%$ \\
\hline Chance na base & $27 \%$ & $30 \%$ & $17 \%$ & $24 \%$ & $21 \%$ & $55 \%$ \\
\hline
\end{tabular}

Notas: $\left({ }^{a}\right)$ A avaliação de desempenho neutra é igual a zero, a positiva é igual a um e a negativa é igual a menos um. $\left(^{\star}\right) p<0,05 .\left(^{* \star}\right) p<0,01$.

Fonte: 1994: Datafolha (1994); 1998: Vox Populi (1998); 2002: Almeida et al. (2002); 2006: Analítica Consultoria (2006).

No caso do PSDB (ver Quadro 31), em 1994, as chances de voto no partido são cerca de três vezes maiores entre os que avaliam o Plano Real de forma neutra, em comparação com os que o avaliam negativamente, e três vezes maiores entre os que o avaliam positivamente, em relação aos que o avaliam de forma neutra. Em 1998, as chances aumentam sete vezes, quando se passa da avaliação negativa para a neutra e desta para a positiva. Nos dois turnos de 2002, como esperado, o impacto da avaliação do governo foi menor, mas ainda assim as chances de voto praticamente dobravam na passagem da avaliação negativa para a neutra e desta para a positiva. Em 2006, quando o partido estava na oposição ao governo, as chances de voto eram cerca de quatro vezes menores entre os que avaliavam o governo de forma neutra, em relação aos que o avaliavam negativamente, e quatro vezes menores entre os que o avaliavam de forma positiva, em relação aos que o avaliavam de forma neutra. Essa situação tornou-se ainda mais forte no segundo turno, quando as diferenças entre as chances de voto entre os três 
grupos foi a maior observada em todo o período, chegando a atingir quase dez vezes.

Com relação à qualidade dos modelos, observa-se que são melhores nas reeleições e nos segundos turnos. Nessas ocasiões, fica sempre mais claro o embate entre governo e oposição representados por PSDB e PT. Em 1994 e nos dois turnos de 2002, a capacidade explicativa dos modelos foi baixa.

No caso do PT, a avaliação de governo exerce enorme impacto sobre as chances de voto no partido quando este buscou a reeleição. Nas eleições anteriores a 2006, as razões de chance são sempre significativas e no sentido esperado, o que indica menores chances de voto entre os que avaliam o governo de forma neutra, em comparação aos que o avaliam negativamente, e entre os que o avaliam de forma neutra, em comparação aos que avaliam positivamente. Essa diferença é maior em 1998 e menor no primeiro turno de 2002.

Na eleição de 2006, especialmente no primeiro turno, a avaliação do desempenho do governo explica mais da metade do comportamento eleitoral com relação ao partido. No segundo turno, observa-se uma queda na razão de chance entre os grupos e no poder explicativo e preditivo do modelo, mas ainda assim é muito grande.

Até este ponto da análise, a avaliação do governo revelou-se a variável mais importante para explicar e prever o comportamento eleitoral em relação ao PSDB e ao PT. De modo geral, a força dessa variável é maior em reeleições e nos segundos turnos, momentos em que a vinculação dos candidatos nos campos governista e oposicionista torna-se mais clara. A avaliação do governo foi menos importante para explicar e prever o voto na eleição de 2002, quando foi mais difícil a identificação, por parte do eleitor, de quem era o candidato governista, tanto pela maior quantidade de candidatos relevantes, quanto pela distância que o candidato do PSDB procurou manter do governo de seu partido. 
Quadro 32: Modelo de regressão logística para a ocorrência de voto no PT - Avaliação de governo $\left(^{\mathrm{a}}\right)$

\begin{tabular}{|c|c|c|c|c|c|c|}
\hline & $\begin{array}{l}\text { Modelo } \\
1994\end{array}$ & $\begin{array}{l}\text { Modelo } \\
1998\end{array}$ & $\begin{array}{c}\text { Modelo } \\
2002 \\
1^{\circ} \text { turno }\end{array}$ & $\begin{array}{c}\text { Modelo } \\
2002 \\
2^{\circ} \text { turno }\end{array}$ & $\begin{array}{c}\text { Modelo } \\
2006 \\
1^{\circ} \text { turno }\end{array}$ & $\begin{array}{c}\text { Modelo } \\
2006 \\
2^{\circ} \text { turno }\end{array}$ \\
\hline \multicolumn{7}{|c|}{ AVALIAÇÃO DE GOVERNO } \\
\hline $\begin{array}{l}\text { Avaliação de } \\
\text { governo }\end{array}$ & $\begin{array}{c}0,499(* \star) \\
(0,07)\end{array}$ & $\begin{array}{c}0,325(* *) \\
(0,07)\end{array}$ & $\begin{array}{c}0,715(* *) \\
(0,05)\end{array}$ & $\begin{array}{c}0,652(* \star) \\
(0,05)\end{array}$ & $\begin{array}{c}14,409(\star \star) \\
(0,12)\end{array}$ & $\begin{array}{c}10,808\left(^{* *}\right) \\
(0,09)\end{array}$ \\
\hline $\mathrm{R}^{2}$ & 0,06 & 0,16 & 0,03 & 0,05 & 0,56 & 0,45 \\
\hline $\begin{array}{l}\mathrm{N} \\
\text { Casos previstos }\end{array}$ & 2.446 & 3.152 & 2.462 & 2.462 & 1.600 & 2.400 \\
\hline $\begin{array}{l}\text { corretamente } \\
\text { Votos no PT previstos }\end{array}$ & $79 \%$ & $77 \%$ & $58 \%$ & $60 \%$ & $81 \%$ & $78 \%$ \\
\hline $\begin{array}{l}\text { corretamente } \\
\text { Previsões de voto no }\end{array}$ & $0 \%$ & $38 \%$ & $53 \%$ & $67 \%$ & $75 \%$ & $77 \%$ \\
\hline PT corretas & $0 \%$ & $49 \%$ & $51 \%$ & $62 \%$ & $87 \%$ & $83 \%$ \\
\hline Chance na base & $29 \%$ & $25 \%$ & $43 \%$ & $54 \%$ & $33 \%$ & $32 \%$ \\
\hline
\end{tabular}

Notas: $\left(^{a}\right)$ A avaliação de desempenho neutra é igual a zero, a positiva é igual a um e a negativa é igual a menos um. $\left.\left(^{*}\right) p<0,05 .{ }^{* *}\right) p<0,01$.

Fonte: 1994: Datafolha (1994); 1998: Vox Populi (1998); 2002: Almeida et al. (2002); 2006: Analítica Consultoria (2006).

\subsection{Análise do impacto das avaliações dos candidatos nas eleições presidenciais brasileiras}

3.4.1. Qualidades que um presidente deve ter

Nossa análise sobre o impacto exercido pela avaliação dos candidatos nas chances de voto no PSDB e no PT nas eleições presidenciais não inclui a eleição de 1994, porque o banco de dados de que dispomos para essa eleição não contém perguntas dessa natureza. Assim, a análise ficará restrita às eleições de 1998, 2002 e 2006. Se, por um lado, essa ausência compromete a análise longitudinal mais acurada, por outro, as evidências que serão apresentadas são suficientes para nos convencer da importância dessa variável nos cálculos que o eleitor faz para tomar sua decisão de voto.

Na eleição de 1998, as principais qualidades que um político deveria ter para ser presidente, na opinião dos eleitores brasileiros, eram a honestidade, a capacidade comprovada para governar e a sinceridade. Ao longo da campanha, as características mais desejadas pelos eleitores sofreram pouca alteração. Em dezembro de 1997, na primeira rodada de 
pesquisa, os eleitores consideravam que era mais importante o presidente ser honesto (29\%) do que ter capacidade comprovada para governar (15\%). Com o andamento da campanha eleitoral, a honestidade perdeu um pouco de importância (21\%) e a capacidade passou a ser a característica mais desejada pelos eleitores (24\%).

Tabela 9: Principais qualidades que um candidato deve ter - campanha de $1998(\mathrm{em} \mathrm{\%})^{2}$

\begin{tabular}{|l|c|c|c|c|}
\hline Qualidade (1998) & $12 / 97$ & $06 / 98$ & $08 / 98$ & $09 / 98$ \\
\hline \hline Ser honesto & 29 & 28 & 25 & 21 \\
\hline Ter capacidade comprovada para governar & 15 & 22 & 22 & 24 \\
\hline Ser sincero & 8 & 15 & 14 & 12 \\
\hline Trazer progresso e desenvolvimento para o Brasil & 10 & 5 & 6 & 9 \\
\hline Ter empenho para melhorar a situação dos mais pobres & 7 & 6 & 7 & 7 \\
\hline Ser trabalhador & 6 & 5 & 6 & 6 \\
\hline Ter visão de futuro & 4 & 3 & 3 & 4 \\
\hline Outros & 14 & 15 & 16 & 17 \\
\hline Nenhuma delas/outra & 1 & 1 & 1 & 0 \\
\hline NS/NR & 6 & 2 & 1 & 2 \\
\hline Total & $\mathbf{1 0 0}$ & $\mathbf{1 0 0}$ & $\mathbf{1 0 0}$ & $\mathbf{1 0 0}$ \\
\hline
\end{tabular}

Fonte: Vox Populi (1998).

Essa mudança durante a campanha deve ser creditada ao clima de instabilidade financeira que o país vivia naquela conjuntura eleitoral. Com efeito, durante o segundo semestre de 1998, ocorreu grave ameaça à estabilidade da moeda nacional, na esteira de uma crise econômica internacional. A oposição passou a apontar a política econômica do governo como a principal causa da fragilidade da economia frente às incertezas econômicas internacionais; 0 governo, por sua vez, defendeu-se afirmando que a crise não era causada por decisões internas, mas por uma crise externa, e que perante esta seria fundamental um presidente capaz e experiente. $O$ argumento principal da campanha governista era que FHC já havia derrotado a inflação e que era o candidato mais capaz de manter a estabilidade da moeda.

A Tabela 10 mostra que, em 1998, os eleitores consideravam que FHC reunia mais qualidades para ser presidente do que seu principal adversário. Isso fica ainda mais claro no que diz respeito à capacidade para governar. A

\footnotetext{
${ }^{2}$ Pergunta: Dentre estas qualidades qual é, na sua opinião, a principal qualidade que um político deve ter para ser Presidente da República?
} 
maior parcela dos eleitores (42\%) considerava que FHC tinha e Lula não tinha essa qualidade, enquanto apenas 11\% acreditam, pelo contrário, que Lula tinha e FHC não. Outros 19\% acreditam que ambos tinham a qualidade, e $28 \%$ diziam que nenhum dos dois tinha capacidade para governar o Brasil. Isso significa que essa qualidade propiciava ao presidente-candidato uma grande vantagem competitiva frente a Lula. Nas duas outras qualidades mais importantes, a diferença entre FHC e Lula não era tão grande, e a maior parcela dos eleitores acreditava que nenhum dos dois era honesto e sincero.

Tabela 10: Opinião dos eleitores sobre quem tem as principais qualidades para ser presidente em 1998 (em \%)

\begin{tabular}{|l|c|c|c|}
\hline Opinião/Qualidade & Capacidade comprovada para governar & Honestidade & Sinceridade \\
\hline \hline FHC tem e Lula não tem & 42 & 23 & 27 \\
\hline Lula tem e FHC não tem & 11 & 14 & 17 \\
\hline Ambos têm & 19 & 15 & 14 \\
\hline Nenhum tem & 28 & 47 & 42 \\
\hline
\end{tabular}

Fonte: Vox Populi (1998), Rodada 5, ago./98.

Os modelos de regressão logística para a ocorrência de intenção de voto no PSDB e no PT, em 1998, tendo como covariáveis a opinião dos eleitores sobre os candidatos, com relação às qualidades que um presidente deve ter, revelam que as opiniões sobre os candidatos exercem importante influência sobre a direção do voto. Para a candidatura de FHC, as características que mais influenciam positivamente as chances de voto foram trazer o progresso e o desenvolvimento, ser confiável, brigar pelo Brasil, ter empenho em melhorar a vida dos mais pobres, ser sincero, ter capacidade comprovada para governar, ter visão de futuro e ter a cara do Brasil. Acreditar que FHC tinha essas características aumentava significativamente as chances de voto no PSDB, entre 42\%, para quem acreditava que ele tinha a cara do Brasil, e $160 \%$, entre os que acreditavam que ele iria trazer progresso e desenvolvimento para o país. Acreditar que FHC empenhava-se em melhorar a situação dos ricos e que era poderoso diminuía as chances de intenção de voto pela metade. 
Quadro 33: Modelo de regressão logística para a ocorrência de voto no PSDB e no PT em 1998 - Qualidades e características do candidato

\begin{tabular}{|c|c|c|c|}
\hline & & Modelo PSDB & Modelo PT \\
\hline \multicolumn{4}{|c|}{ VARIÁVEIS DAS QUALIDADES E CARACTERÍSTICAS DO CANDIDATO } \\
\hline \multirow{2}{*}{\multicolumn{2}{|c|}{ Tem capacidade comprovada para governar }} & $1,592(* \star)$ & $2,127(* *)$ \\
\hline & & $(0,18)$ & $(0,17)$ \\
\hline \multirow{2}{*}{\multicolumn{2}{|c|}{ É sincero }} & $1,641(* \star)$ & 1,305 \\
\hline & & $(0,14)$ & $(0,19)$ \\
\hline \multirow{2}{*}{\multicolumn{2}{|c|}{ É honesto }} & $0,717\left(^{*}\right)$ & 1,01 \\
\hline & & $(0,15)$ & $(0,18)$ \\
\hline \multirow{2}{*}{\multicolumn{2}{|c|}{ É realizador }} & 1,125 & 1,278 \\
\hline & & $(0,15)$ & $(0,17)$ \\
\hline \multirow{2}{*}{\multicolumn{2}{|c|}{ É confiável }} & $2,487(* \star)$ & $2,279(* \star)$ \\
\hline & & $(0,15)$ & $(0,18)$ \\
\hline \multirow{2}{*}{\multicolumn{2}{|c|}{ É trabalhador }} & 0,896 & $0,583(*)$ \\
\hline & & $(0,15)$ & $(0,21)$ \\
\hline \multirow{2}{*}{\multicolumn{2}{|c|}{ É decidido }} & 0,877 & 0,94 \\
\hline & & $(0,17)$ & $(0,2)$ \\
\hline \multirow{2}{*}{\multicolumn{2}{|c|}{ É sério }} & 0,962 & 0,965 \\
\hline & & $(0,16)$ & $(0,21)$ \\
\hline \multirow{2}{*}{\multicolumn{2}{|c|}{ Tem visão de futuro }} & $1,506(\star \star)$ & $2,112(* \star)$ \\
\hline & & $(0,15)$ & $(0,18)$ \\
\hline \multirow{2}{*}{\multicolumn{2}{|c|}{ Vai trazer progresso e desenvolvimento para o Brasil }} & $2,612(* *)$ & $2,908(* *)$ \\
\hline & & $(0,14)$ & $(0,18)$ \\
\hline \multirow{2}{*}{\multicolumn{2}{|c|}{ Entende problemas das pessoas como você }} & 1,238 & 1,323 \\
\hline & & $(0,14)$ & $(0,19)$ \\
\hline \multirow{2}{*}{\multicolumn{2}{|c|}{ Tem empenho para melhorar a situação dos mais pobres }} & $1,832(* \star)$ & 0,793 \\
\hline & & $(0,14)$ & $(0,2)$ \\
\hline \multirow{2}{*}{\multicolumn{2}{|c|}{ Tem a cara do Brasil }} & $1,424(\star \star)$ & $1,461\left(^{\star}\right)$ \\
\hline & & $(0,13)$ & $(0,18)$ \\
\hline \multirow{2}{*}{\multicolumn{2}{|c|}{ Tem empenho para melhorar a situação dos mais ricos }} & $0,463(* \star)$ & $0,500(* \star)$ \\
\hline & & $(0,11)$ & $(0,15)$ \\
\hline \multirow{2}{*}{\multicolumn{2}{|c|}{ Tem preparo para governar }} & 0,738 & $1,998(* \star)$ \\
\hline & & $(0,18)$ & $(0,18)$ \\
\hline \multirow{2}{*}{\multicolumn{2}{|c|}{ Vai brigar pelos direitos do Brasil }} & $1,844(* \star)$ & 0,875 \\
\hline & & $(0,15)$ & $(0,2)$ \\
\hline \multirow{2}{*}{\multicolumn{2}{|c|}{ É poderoso }} & $0,450(* *)$ & 0,885 \\
\hline & & $(0,15)$ & $(0,15)$ \\
\hline \multicolumn{2}{|l|}{$\mathrm{R}^{2}$} & 0,42 & 0,49 \\
\hline \multicolumn{2}{|c|}{$\mathrm{N}$} & 3.195 & 3.195 \\
\hline \multicolumn{2}{|c|}{ Casos previstos corretamente } & $77 \%$ & $87 \%$ \\
\hline \multicolumn{2}{|c|}{ Votos no PSDB previstos corretamente } & $71 \%$ & $67 \%$ \\
\hline \multicolumn{2}{|c|}{ Previsões de voto no PSDB corretas } & $76 \%$ & $74 \%$ \\
\hline \multicolumn{2}{|c|}{ Chance na base } & $22 \%$ & $6 \%$ \\
\hline
\end{tabular}

Notas: $\left(^{\star}\right) p<0,05 .\left(^{(*}\right) p<0,01$.

Fonte: Vox Populi (1998).

Saber a opinião dos eleitores sobre as qualidades de FHC possibilita explicar cerca de $42 \%$ das intenções de voto no partido e permitia ao modelo prever corretamente mais de $70 \%$ dos votos no partido. 
Para as chances de voto em Lula, as características mais influentes foram trazer progresso e desenvolvimento, ser confiável, ter capacidade comprovada para governar, ter visão de futuro e ter preparo. Quando o eleitor acreditava que Lula era dotado dessas características, as chances de voto aumentavam significativamente entre $100 \%$, para os que acreditavam que o candidato tinha preparo para governar o Brasil, e 190\%, entre os que consideravam que ele iria trazer progresso e desenvolvimento para o país. Acreditar que Lula era trabalhador e que se empenhava em melhorar a vida dos ricos fazia diminuir as chances de voto no PT pela metade. O modelo para o PT com as covariáveis das opiniões dos eleitores sobre Lula tem maior poder explicativo do que o modelo para o PSDB e consegue explicar quase metade das intenções de voto e prever mais de dois terços das intenções de voto.

Em 2002, as principais qualidades que um candidato a presidente deveria ter, segundo a opinião dos eleitores, praticamente não sofreram alterações durante a campanha eleitoral. De fato, a corrida eleitoral daquele ano transcorreu sem grandes eventos significativos que pudessem alterar os rumos das campanhas. Apesar da aparente tranqüilidade, essa eleição foi marcada por maior disputa entre os diversos candidatos. Ainda antes das definições oficiais das candidaturas, entre os meses finais de 2001 e os iniciais de 2002, a pré-candidata pelo PFL, Roseana Sarney, apareceu com força nas pesquisas eleitorais: especialmente em fevereiro de 2002, segundo dados do Datafolha, ela ficava tecnicamente empatada com Lula na simulação do primeiro turno e à frente dele na simulação do segundo turno. Essa boa posição nas pesquisas tornava a candidatura de Roseana quase irreversível, uma vez que se apresentava como a mais forte entre os governistas. Contudo, a força pré-eleitoral de Roseana ruiu após a divulgação pela imprensa da noticia da apreensão de uma pilha de notas de $\mathrm{R} \$ 50,00$, totalizando mais de $\mathrm{R} \$ 1,3$ milhão, na sede da empresa Lunus, de propriedade da candidata em sociedade com seu marido. Existem várias versões que procuraram dar conta da origem da operação policial que abortou a candidatura própria do PFL. Independentemente de tais versões, o que importa foi que a operação justificou o rompimento do PFL com o 
governo e a implosão da aliança eleitoral e governamental PSDB-PFL, que havia se mantido durante os oito anos de FHC.

A queda de Roseana abriu espaço para o crescimento da candidatura de Ciro Gomes. Esse dissidente do PSDB lançou sua candidatura por uma aliança partidária formada pelo Partido Popular Socialista (PPS), pelo Partido Trabalhista Brasileiro (PTB) e pelo Partido Democrático Trabalhista (PDT). Já no início de julho de 2002, ele conseguia empate técnico com Serra, com $20 \%$ das intenções de voto, ultrapassando-o durante o mês e atingindo, ao final deste, $28 \%$ das intenções de voto. Além disso, nas simulações para o segundo turno, Ciro chegou a aparecer à frente de Lula. Essa situação manteve-se estável até o início do horário gratuito de propaganda eleitoral, quando pesados ataques oriundos da campanha do PSDB derrubaram rapidamente os índices de intenção de voto do candidato. A partir de agosto, a disputa praticamente se estabilizou, com a consolidação da candidatura de Lula e com o fortalecimento da de Serra.

Do ponto de vista do eleitor, as características mais desejadas para um presidente eram fazer mais pelos mais pobres, defender os interesses dos trabalhadores e ter um bom plano de governo. Essas opiniões fazem acreditar nos argumentos apresentados na tese de Castro (1994), especialmente porque existe uma relação de dependência entre considerar essa característica a mais importante e a renda do eleitor, de forma que essa resposta foi muito mais freqüente entre os com renda abaixo de cinco salários mínimos - ou seja: os mais pobres eram os que consideravam mais importante um presidente fazer mais pelos mais pobres. Os de renda mais alta, acima de cinco salários mínimos, desejavam mais um presidente que tivesse um bom plano de governo e experiência administrativa. Todas as outras respostas são independentes da renda do eleitor. 
Tabela 11: Principais qualidades que um candidato deve ter - campanha de $2002(\mathrm{em} \mathrm{\% )})^{3}$

\begin{tabular}{|l|c|c|c|c|c|c|c|c|}
\hline Qualidade - 2002 & $04 / 02$ & $05 / 02$ & $05 / 02$ & $06 / 02$ & $07 / 02$ & $08 / 02$ & $09 / 02$ & $10 / 02$ \\
\hline \hline $\begin{array}{l}\text { Fará mais pelos mais } \\
\text { pobres }\end{array}$ & 11 & 37 & 31 & 33 & 31 & 33 & 30 & 34 \\
\hline $\begin{array}{l}\text { Defenderá os interesses dos } \\
\text { trabalhadores }\end{array}$ & 4 & 12 & 12 & 11 & 12 & 12 & 13 & 11 \\
\hline Bom plano de governo & 11 & 9 & 10 & 11 & 10 & 11 & 13 & 12 \\
\hline $\begin{array}{l}\text { Conhece os problemas da } \\
\text { população }\end{array}$ & 4 & 10 & 9 & 11 & 10 & 10 & 10 & 8 \\
\hline Pulso forte, decidido & 17 & 5 & 7 & 6 & 6 & 6 & 5 & 5 \\
\hline $\begin{array}{l}\text { Brigar pelos interesses do } \\
\text { Brasil no exterior }\end{array}$ & 12 & 3 & 4 & 3 & 2 & 3 & 5 & 4 \\
\hline Passado limpo & 3 & 4 & 4 & 5 & 5 & 4 & 4 & 4 \\
\hline Preparo para ser presidente & 7 & 3 & 3 & 4 & 5 & 5 & 3 & 4 \\
\hline $\begin{array}{l}\text { Fazer uma campanha limpa } \\
\text { (sem atacar os adversários) }\end{array}$ & 5 & 3 & 4 & 3 & 5 & 3 & 5 & 4 \\
\hline $\begin{array}{l}\text { Experiência administrativa } \\
\text { para ser Presidente }\end{array}$ & 5 & 4 & 4 & 4 & 3 & 3 & 3 & 3 \\
\hline $\begin{array}{l}\text { Preocupar-se com pessoas } \\
\text { como o(a) Sr.(a) }\end{array}$ & 8 & 2 & 2 & 2 & 2 & 3 & 2 & 2 \\
\hline Outros & 11 & 7 & 7 & 6 & 7 & 6 & 7 & 8 \\
\hline Nenhuma delas & 0 & 0 & 0 & 0 & 1 & 0 & 0 & 0 \\
\hline NS NR & 1 & 1 & 1 & 1 & 1 & 1 & 0 & 1 \\
\hline Total & 100 & 100 & 100 & 100 & 100 & 100 & 100 \\
\hline
\end{tabular}

Fonte: Ipsos Opinion (2002).

Tabela 12: Opinião dos eleitores sobre quem tem as principais qualidades para ser presidente em 2002 (em \%)

\begin{tabular}{|l|c|c|c|}
\hline Opinião/Qualidade & Ajudar os mais pobres & Defender os trabalhadores & Ter plano de governo \\
\hline \hline Serra tem e Lula não tem & 17 & 15 & 39 \\
\hline Lula tem e Serra não tem & 46 & 51 & 23 \\
\hline Ambos têm & 30 & 30 & 30 \\
\hline Nenhum tem & 7 & 4 & 8 \\
\hline
\end{tabular}

Fonte: Ipsos Opinion (2002), rodada 8, out./2002.

A Tabela 12 mostra que a grande maioria dos eleitores considerava que Lula tinha as características mais importantes para um presidente. Nada menos que $76 \%$ acreditavam que ele ajudaria os mais pobres, $81 \%$ que ele defenderia os trabalhadores e 53\% que ele tinha plano de governo. Com relação a José Serra, menos da metade dos eleitores acreditava que ele tinha as duas principais qualidades, e mais de dois terços consideravam que ele tinha bom plano de governo. Ou seja, Lula tinha uma posição mais segura

3 Pergunta: Agora, vou ler algumas características ou qualidades que um candidato a Presidente poderia ter. Destas, qual o(a) Sr.(a) considera a mais importante na hora de escolher em quem vai votar para Presidente? 
que seu adversário, tendo em vista as qualidades que os eleitores julgavam importantes. Sem dúvida, essa percepção por parte do eleitorado contribuiu para a vitória petista naquela eleição.

O modelo de regressão logística para a intenção de voto no PSDB, com as covariáveis referentes às opiniões dos eleitores sobre as qualidades de José Serra, mostra que suas chances de voto aumentavam de modo significativo entre aqueles que acreditavam que ele tinha a qualidade de defender os trabalhadores, que tinha plano de governo, que era sensato e equilibrado, que ajudaria os mais pobres e traria tranqüilidade ao país. Acreditar que José Serra era dono dessas qualidades fazia as chances de voto no PSDB aumentarem entre $78 \%$, no caso de trazer tranqüilidade ao país, até $328 \%$, no caso de defender os trabalhadores. Acreditar que Serra teria a qualidade de defender o Brasil e de ser experiente não foram significantes para as chances de intenção de voto no partido. Enquanto isso, entre os que consideravam que ele tinha a "qualidade" de defender os interesses dos ricos, a chance de intenção de voto era cerca de $34 \%$ da observada entre os que não compartilhavam dessa opinião. Conhecer as opiniões dos eleitores sobre José Serra com respeito a essas qualidades permite ao modelo explicar 58\% das intenções de voto no PSDB e prever corretamente mais de $80 \%$ dos votos no partido.

Para as chances de intenção de voto em Lula, as características que mais as influenciaram foram ter plano de governo, defender o Brasil, trazer tranqüilidade, ser sensato e equilibrado e ter experiência. O impacto sobre as chances variou entre $129 \%$, para aqueles que acreditam que Lula tinha experiência para ser presidente, e 313\%, entre os que consideravam que ele tinha plano de governo. Acreditar que Lula teria a qualidade de ajudar os mais pobres e defender os trabalhadores não foram significantes para as chances de intenção de voto no partido, porque a grande maioria dos eleitores acreditava nisso e essas opiniões não distinguiam o eleitorado. Entre os que tinham a opinião de que Lula defenderia os interesses dos ricos, a chance de intenção de voto no PT representava $29 \%$ daquela observada entre os que não tinham essa opinião. Conhecer as posições dos eleitores 
sobre Lula a respeito a essas qualidades permite ao modelo explicar $71 \%$ das intenções de voto no PT e prever corretamente 95\% dos votos no partido.

Quadro 34: Modelo de regressão logística para a ocorrência de voto no PSDB e no PT em 2002 - Qualidade e características do candidato

\begin{tabular}{|c|c|c|c|}
\hline & & $\begin{array}{c}\text { Modelo PSDB } \\
2^{\circ} \text { turno }\end{array}$ & $\begin{array}{c}\text { Modelo PT } \\
2^{\circ} \text { turno } \\
\end{array}$ \\
\hline \multicolumn{4}{|c|}{ VARIÁVEIS DAS QUALIDADES E CARACTERÍSTICAS DO CANDIDATO } \\
\hline & Ajudará os mais pobres & $\begin{array}{c}1,941(* *) \\
(0,2)\end{array}$ & $\begin{array}{l}1,476 \\
(0,33)\end{array}$ \\
\hline & Defenderá os trabalhadores & $\begin{array}{c}4,277(* \star \\
(0,2)\end{array}$ & $\begin{array}{l}1,379 \\
(0,36)\end{array}$ \\
\hline & É sensato e equilibrado & $\begin{array}{c}2,466\left(^{* *}\right) \\
(0,25)\end{array}$ & $\begin{array}{c}2,347\left(^{* *}\right) \\
(0,22)\end{array}$ \\
\hline & Tem plano de governo & $\begin{array}{c}3,725(\star \star \\
(0,23)\end{array}$ & $\begin{array}{c}4,125(* *) \\
(0,25)\end{array}$ \\
\hline & Tem experiência & $\begin{array}{l}1,103 \\
(0,26)\end{array}$ & $\begin{array}{c}2,290(* *) \\
(0,18)\end{array}$ \\
\hline & Defenderá os ricos & $\begin{array}{c}0,339\left({ }^{*}\right) \\
(0,14)\end{array}$ & $\begin{array}{c}0,290\left({ }^{* *}\right) \\
(0,17)\end{array}$ \\
\hline & Trará tranqüilidade & $\begin{array}{c}1,781(* *) \\
(0,21)\end{array}$ & $\begin{array}{c}3,532(* *) \\
(0,22)\end{array}$ \\
\hline & Vai defender o Brasil & $\begin{array}{l}1,318 \\
(0,23) \\
\end{array}$ & $\begin{array}{c}3,619(* *) \\
(0,22) \\
\end{array}$ \\
\hline \multicolumn{2}{|l|}{$\mathrm{R}^{2}$} & 0,58 & 0,71 \\
\hline \multicolumn{2}{|c|}{$\mathrm{N}$} & 2.004 & 2.004 \\
\hline \multicolumn{2}{|c|}{ Casos previstos corretamente } & $84 \%$ & $89 \%$ \\
\hline \multirow{2}{*}{\multicolumn{2}{|c|}{ Votos no PSDB previstos corretamente }} & $83 \%$ & $95 \%$ \\
\hline & & $70 \%$ & $88 \%$ \\
\hline \multicolumn{2}{|c|}{ Chance na base } & $3 \%$ & $3 \%$ \\
\hline
\end{tabular}

Notas: $\left({ }^{*}\right) p<0,05 .(* \star) p<0,01$.

Fonte: Fonte: Ipsos Opinion (2002).

Assim como em 2002, a campanha de 2006 transcorreu sem alterações significativas nas principais qualidades que os eleitores julgavam serem importantes para um presidente da República. Contudo, diferentemente de 2002, a principal qualidade passou a ser o combate a corrupção. A emergência dessa qualidade como a mais importante em 2006 não ocorreu sem motivações fortes. A despeito da excelente avaliação do governo Lula durante a reta final da campanha eleitoral, diversas denúncias de corrupção vinham atingindo o governo desde 2004. A primeira envolveu o então assessor da Casa Civil Waldomiro Diniz, flagrado em vídeo no momento de receber propina de um empresário ligado à operação de bingos e jogos de azar. Supostamente, esse dinheiro seria utilizado para financiar 
campanhas eleitorais de candidatos do Rio de Janeiro. Para investigar essa suposição, o Senado Federal instalou no final de junho de 2005 a Comissão Parlamentar de Inquérito dos Bingos. Isso ocorreu após inúmeras tentativas governistas de abafar o caso.

Também conhecida como "CPI do Fim do Mundo", aquela comissão passou a investigar todo tipo de denúncia contra o governo, como a suposta ligação entre o assassinato do prefeito Celso Daniel (PT) e o esquema de financiamento de campanhas, as possíveis irregularidades na Prefeitura de Ribeirão Preto durante a gestão de Antonio Palocci, a suposta doação de casas de bingo ou a remessa de dólares vindos de Cuba para a campanha de Lula, entre outros temas explosivos.

A situação para o governo ficou ainda pior quando, em março de 2006, a CPI ouviu o caseiro Francenildo Costa, que desmentiu Palocci, ao afirmar que o ex-ministro freqüentava uma mansão em Brasília usada por lobistas para fechar negócios suspeitos e promover festas com prostitutas. O local, conhecido como "República de Ribeirão Preto", havia sido alugado por ex-assessores de Palocci. O depoimento de Costa deflagrou outro escândalo, pois ele teve seu sigilo bancário ilegalmente violado logo após participar da CPI. Informações protegidas pelo sigilo bancário foram divulgadas pela imprensa, revelando que o caseiro havia recebido cerca de $\mathrm{R} \$$ 35.000,00 em depósitos, quantia incompatível com sua renda mensal de $\mathrm{R} \$ 700,00$. A denúncia tinha como intuito desqualificar as declarações do caseiro, sugerindo a idéia de que ele teria recebido esse dinheiro para mentir na $\mathrm{CPI}$ e prejudicar o então ministro da Fazenda. Depois, soube-se que tais depósitos haviam sido feitos pelo pai de Costa, empresário do setor de transportes. Embora negasse a paternidade, decorrente de relação extraconjugal, o empresário confirmou ter feito o depósito. Esclarecida essa situação, o foco passou a ser a quebra do sigilo bancário de Costa - ato ilegal, feito sem o aval da Justiça. O nome de Palocci foi logo envolvido nesse processo, o que levou a sua saída do Ministério.

Em junho de 2005, outro escândalo atingiu o governo Lula. Dessa vez, o então funcionário dos Correios Maurício Marinho também foi flagrado em vídeo ao negociar propina em nome do então deputado federal pelo PTB Roberto Jefferson. Entregue à própria sorte, Jefferson denunciou deputados 
da base governista que recebiam um "mensalão" de $\mathrm{R} \$ 30.000,00$ do tesoureiro do PT Delúbio Soares. Segundo Jefferson afirmou à época, o dinheiro do "mensalão" viria de empresas estatais e privadas e seria entregue aos parlamentares por operadores como o publicitário Marcos Valério e o líder do Partido Progressista (PP) na Câmara José Janene. A partir disso, foi deflagrada a CPI dos Correios, para investigar o envolvimento de empresas estatais para alimentar os recursos do "mensalão". As denúncias de Jefferson atingiram diretamente a cúpula do PT e nomes como o do ministro da Casa Civil José Dirceu, o então presidente do PT José Genoíno e o secretário geral do PT Sílvio Pereira, além de Delúbio Soares. Os desgastes provocados por essas acusações levaram à queda de Dirceu, até então principal figura do governo Lula, e de Genoíno, umas das principais lideranças históricas do PT. As revelações de Jefferson envolviam indiretamente também o presidente. Segundo o ex-deputado, Lula, desde o começo de 2005, tinha ciência dos fatos ocorridos, mas até então não tinha adotado nenhuma providência. Todavia, neste caso, o impacto foi quase nulo. Para a população, parece ter sido suficiente a declaração do presidente de que "não sabia de nada" do que estava acontecendo e que, se soubesse, teria tomado as atitudes cabíveis.

A Analítica Consultoria incluiu perguntas em suas pesquisas eleitorais para tentar levantar e medir as percepções dos eleitores em relação ao envolvimento de Lula nesses escândalos de corrupção. Para a grande maioria dos entrevistados, nenhuma prova foi encontrada contra Lula (81\%) e, quando se provou que seus colaboradores estavam envolvidos, Lula não hesitou em demiti-los (77\%). Há também uma maioria que concorda que Lula se livrou dos problemas, seja fingindo não ter nada a ver com os fatos acontecidos (63\%), seja pondo a culpa dos erros nos outros (55\%).

Do ponto de vista do eleitor, além da qualidade de combater a corrupção, um presidente deveria ajudar os mais pobres, conhecer os problemas do Brasil, ter preparo para o cargo e boas propostas para resolver os problemas do país. A opinião a respeito do quesito "combate à corrupção" é dependente da renda do eleitor: eleitores com renda acima de cinco salários mínimos desejam mais essa qualidade que os eleitores com renda abaixo desse patamar. Assim como em 2002, o desejo de um presidente que 
ajude os mais pobres é dependente da renda do eleitor, de forma que os mais pobres desejam mais essa qualidade.

Tabela 13: Principais qualidades que um candidato deve ter - campanha de $2006\left(\right.$ em \%) ${ }^{4}$

\begin{tabular}{|l|c|c|c|c|c|}
\hline Qualidade (2006) & $07 / 06$ & $08 / 06$ & $09 / 06$ & $09 / 06$ & $10 / 06$ \\
\hline \hline Vai combater a corrupção & 20 & 22 & 26 & 27 & 25 \\
\hline Vai ajudar os mais pobres & 17 & 13 & 13 & 14 & 12 \\
\hline Conhece os problemas do Brasil & & & 12 & 11 & 16 \\
\hline Preparo para o cargo & 14 & 17 & 10 & 8 & 8 \\
\hline Tem boas propostas para resolver os problemas do Brasil & 11 & 11 & 8 & 8 & 9 \\
\hline É sincero & 8 & 9 & 5 & 5 & 5 \\
\hline Respeita o povo & 9 & 7 & 3 & 4 & \\
\hline Outros & 19 & 20 & 23 & 22 & 24 \\
\hline Não sabe/Não respondeu & 2 & 2 & 0 & 1 & 1 \\
\hline Total & $\mathbf{1 0 0}$ & $\mathbf{1 0 0}$ & $\mathbf{1 0 0}$ & $\mathbf{1 0 0}$ & $\mathbf{1 0 0}$ \\
\hline
\end{tabular}

Fonte: Analítica Consultoria (2006).

A Tabela 14 mostra que quase metade dos eleitores acreditava que tanto Alckmin (46\%), como Lula (47\%) tinham a qualidade de combater a corrupção. Ou seja, no que tange à principal qualidade desejada pelos eleitores, existia um equilíbrio entre os candidatos do PSDB e do PT. Nas outras duas qualidades mais importantes para os eleitores, Lula estava mais bem posicionado que seu principal adversário: $75 \%$ dos eleitores acreditavam que Lula ajudaria os mais pobres, contra 47\% para Alckmin, e 65\% consideravam Lula preparado para o cargo, contra 60\% para Alckmin. Dessa forma, mais uma vez, assim como em 2002, Lula aparecia como o melhor candidato frente às qualidades que os eleitores julgavam mais importantes para um presidente da República.

Tabela 14: Opinião dos eleitores sobre quem tem as principais qualidades para ser presidente em 2006 (em \%)

\begin{tabular}{|l|c|c|c|}
\hline Opinião/Qualidade & $\begin{array}{c}\text { Vai combater a } \\
\text { corrupção }\end{array}$ & $\begin{array}{c}\text { Ajudar os mais } \\
\text { pobres }\end{array}$ & $\begin{array}{c}\text { Tem preparo para o } \\
\text { cargo }\end{array}$ \\
\hline \hline Alckmin tem e Lula não tem & 29 & 18 & 29 \\
\hline Lula tem e Alckmin não tem & 30 & 46 & 34 \\
\hline Ambos têm & 17 & 29 & 31 \\
\hline Nenhum tem & 24 & 6 & 6 \\
\hline
\end{tabular}

Fonte: Analítica Consultoria (2006), rodada 6, out./2006.

\footnotetext{
${ }^{4}$ Pensando agora em todas essas características, para o(a) Sr.(a) qual destas tem mais importância na hora de escolher um novo Presidente?
} 
O modelo de regressão logística para a intenção de voto no PSDB com as covariáveis referentes a opiniões dos eleitores sobre as qualidades de Alckmin mostra que suas chances de voto aumentavam significativamente entre aqueles que acreditavam que ele tinha a qualidade de dar esperança de uma vida melhor, de saber governar, de combater a corrupção, de melhorar a vida das pessoas, de não deixar seus auxiliares roubarem e de ajudar os mais pobres. Acreditar que Alckmin tinha essas qualidades fazia as chances de voto no PSDB aumentar entre $63 \%$, no caso de ajudar os mais pobres, até $154 \%$, no caso de dar esperança de uma vida melhor. Conhecer as opiniões dos eleitores sobre Alckmin com respeito às qualidades permite ao modelo explicar $64 \%$ das intenções de voto no PSDB e prever corretamente mais de $80 \%$ dos votos no partido.

As características que mais influenciaram as chances de intenção de voto em Lula foram dar esperança de uma vida melhor, saber governar, ter preparo para o cargo, melhorar a vida das pessoas, ajudar os pobres, não fazer promessas que não vai cumprir e ser sincero. O impacto sobre as chances variou entre $70 \%$, para aqueles que acreditavam que Lula era sincero, e $223 \%$, entre os que consideravam que ele dava esperança de uma vida melhor. Conhecer as posições dos eleitores sobre Lula a respeito dessas qualidades permite ao modelo explicar $72 \%$ das intenções de voto no PT e prever corretamente quase $90 \%$ dos votos no partido.

Como revela a análise que fizemos, as principais qualidades que, na opinião dos eleitores, deve ter um presidente da República tiveram grande impacto na decisão do voto. Os eleitores selecionam seus candidatos a partir de critérios objetivos, ou seja, tendem a votar naqueles que acreditam que tem as qualidades necessárias. Poder-se-ia objetar que se trata de um raciocínio tautológico, uma vez que se poderia afirmar que o eleitor tende a atribuir a seu candidato as qualidades e capacidades que admira. Entretanto, não parece que seja assim, uma vez que parcelas ponderáveis dos eleitores acreditam que ambos os candidatos possuem as qualidades que desejam e que muitas vezes as opiniões sobre a existência das qualidades nos candidatos superam em muito seus índices de intenção de voto. Isso quer dizer que muitos eleitores não votam nos candidatos simplesmente porque estes parecem possuir certas qualidades. As correlações entre as intenções de voto no PSDB e no PT e as opiniões sobre 
as qualidades dos candidatos mostram que essas variáveis não são as mesmas.

Para que isso fosse verdade, as correlações deveriam ter valores acima de 0,6.

Os dados mostram que a grande maioria fica abaixo desse valor.

Quadro 35: Modelo de regressão logística para a ocorrência de voto no PSDB e no PT em 2006 - Qualidades e características do candidato

\begin{tabular}{|c|c|c|c|}
\hline & & $\begin{array}{l}\text { Modelo PSDB } \\
2^{\circ} \text { turno }\end{array}$ & $\begin{array}{l}\text { Modelo PT } \\
2^{\circ} \text { turno }\end{array}$ \\
\hline \multicolumn{4}{|c|}{ VARIÁVEIS DAS QUALIDADES E CARACTERÍSTICAS DO CANDIDATO } \\
\hline & Vai combater a corrupção & $\begin{array}{c}1,802(* \star) \\
(0,15)\end{array}$ & $\begin{array}{c}1,439\left(^{*}\right) \\
(0,17)\end{array}$ \\
\hline & Conhece os problemas do Brasil & $\begin{array}{l}0,914 \\
(0,18)\end{array}$ & $\begin{array}{l}0,949 \\
(0,21)\end{array}$ \\
\hline & Preparo para o cargo & $\begin{array}{c}1,523\left({ }^{*}\right) \\
(0,19)\end{array}$ & $\begin{array}{c}2,285(* *) \\
(0,2)\end{array}$ \\
\hline & Não vai deixar os outros roubarem & $\begin{array}{c}1,723(* *) \\
(0,15)\end{array}$ & $\begin{array}{c}1,452\left(^{*}\right) \\
(0,18)\end{array}$ \\
\hline & Vai ajudar os mais pobres & $\begin{array}{c}1,632(* *) \\
(0,16)\end{array}$ & $\begin{array}{c}1,820(* *) \\
(0,23)\end{array}$ \\
\hline & $\begin{array}{l}\text { Tem boas propostas para resolver os } \\
\text { problemas do Brasil }\end{array}$ & $\begin{array}{c}1,469\left(^{*}\right) \\
(0,19)\end{array}$ & $\begin{array}{c}1,604\left(^{*}\right) \\
(0,19)\end{array}$ \\
\hline & Sabe escolher seus ministros e auxiliares & $\begin{array}{l}1,266 \\
(0,16)\end{array}$ & $\begin{array}{l}0,875 \\
(0,19)\end{array}$ \\
\hline & Não faz promessas que não vai cumprir & $\begin{array}{c}1,366\left(^{*}\right) \\
(0,15)\end{array}$ & $\begin{array}{c}1,732(* *) \\
(0,17)\end{array}$ \\
\hline & É gente como a gente & $\begin{array}{l}1,334 \\
(0,15)\end{array}$ & $\begin{array}{c}0,657\left(^{*}\right) \\
(0,21)\end{array}$ \\
\hline & $\begin{array}{l}\text { Vai melhorar a vida que você e sua família } \\
\text { levam }\end{array}$ & $\begin{array}{c}1,782(* *) \\
(0,16)\end{array}$ & $\begin{array}{c}1,849(* *) \\
(0,19)\end{array}$ \\
\hline & É sincero & $\begin{array}{l}1,149 \\
(0,16)\end{array}$ & $\begin{array}{c}1,699(* *) \\
(0,18)\end{array}$ \\
\hline & $\begin{array}{l}\text { Tem um passado limpo, sem acusações de } \\
\text { corrupção }\end{array}$ & $\begin{array}{l}1,197 \\
(0,15)\end{array}$ & $\begin{array}{l}0,895 \\
(0,17)\end{array}$ \\
\hline & $\begin{array}{l}\text { Faz a gente ter esperança de uma vida } \\
\text { melhor }\end{array}$ & $\begin{array}{c}2,544(* *) \\
(0,18)\end{array}$ & $\begin{array}{c}3,232(* *) \\
(0,2)\end{array}$ \\
\hline & Já mostrou que sabe governar & $\begin{array}{c}2,024(* *) \\
(0,17)\end{array}$ & $\begin{array}{c}2,763(* *) \\
(0,2)\end{array}$ \\
\hline & $\begin{array}{l}\text { Tem controle sobre seus assessores e } \\
\text { ministros }\end{array}$ & $\begin{array}{l}0,888 \\
(0,17)\end{array}$ & $\begin{array}{l}1,276 \\
(0,2)\end{array}$ \\
\hline & Tem autoridade e pulso firme & $\begin{array}{l}1,416 \\
(0,18) \\
\end{array}$ & $\begin{array}{l}1,338 \\
(0,18) \\
\end{array}$ \\
\hline \multicolumn{2}{|l|}{$\mathrm{R}^{2}$} & 0,64 & 0,72 \\
\hline \multicolumn{2}{|c|}{ N } & 2.400 & 2.400 \\
\hline \multicolumn{2}{|c|}{ Casos previstos corretamente } & $86 \%$ & $89 \%$ \\
\hline \multicolumn{2}{|c|}{ Votos no PSDB previstos corretamente } & $83 \%$ & $92 \%$ \\
\hline \multicolumn{2}{|c|}{ Previsões de voto no PSDB corretas } & $80 \%$ & $88 \%$ \\
\hline \multicolumn{2}{|c|}{$\begin{array}{l}\text { Chance na base } \\
\end{array}$} & $2 \%$ & $3 \%$ \\
\hline
\end{tabular}

Notas: $\left(^{*}\right) p<0,05 .\left({ }^{* *}\right) p<0,01$.

Fonte: Analítica Consultoria (2006). 
3.4.2. Capacidade dos candidatos para resolver os principais problemas do país

A análise da influência que a opinião sobre os candidatos tem sobre a intenção do voto não fica completa se não considerarmos outro conjunto de variáveis, as quais também devem exercer impacto naquela intenção. Referimo-nos às posições dos eleitores quanto aos principais problemas do país e às suas opiniões sobre quais candidatos são capazes de solucioná-los.

Tabela 15: Principais problemas do país nas campanhas eleitorais de 1998, 2002 e 2006

\begin{tabular}{|c|c|c|c|c|c|c|c|c|c|c|c|c|c|c|c|c|c|}
\hline \multirow{2}{*}{$\begin{array}{l}\text { Principais } \\
\text { problemas do } \\
\text { país nas } \\
\text { campanhas } \\
\text { presidenciais }\end{array}$} & \multicolumn{3}{|c|}{$1998^{5}$} & \multicolumn{8}{|c|}{$2002^{6}$} & \multicolumn{6}{|c|}{$2006^{7}$} \\
\hline & $12 / 97$ & $06 / 98$ & $07 / 98$ & $04 / 02$ & $05 / 02$ & $05 / 02$ & $06 / 02$ & $07 / 02$ & $08 / 02$ & $09 / 02$ & $10 / 02$ & $06 / 06$ & $07 / 06$ & $08 / 06$ & $09 / 06$ & $09 / 06$ & $10 / 6$ \\
\hline Saúde & 39 & 38 & 38 & 6 & 3 & 4 & 6 & 9 & 8 & 8 & 8 & 23 & 31 & 28 & 47 & 48 & 48 \\
\hline Emprego & 37 & 35 & 40 & 45 & 53 & 49 & 46 & 44 & 47 & 43 & 43 & 12 & 8 & 9 & 16 & 14 & 16 \\
\hline Educação & 3 & 3 & 3 & 3 & 4 & 4 & 6 & 4 & 4 & 6 & 5 & 19 & 26 & 26 & 10 & 9 & 11 \\
\hline $\begin{array}{l}\text { Fome e } \\
\text { pobreza }\end{array}$ & 4 & 6 & 4 & 4 & 4 & 4 & 7 & 8 & 6 & 8 & 9 & 4 & 6 & 7 & 5 & 5 & 4 \\
\hline Segurança & 6 & 5 & 4 & 15 & 17 & 16 & 14 & 15 & 16 & 12 & 11 & 9 & 12 & 13 & 6 & 8 & 5 \\
\hline Corrupção & 3 & 2 & 2 & 6 & 4 & 6 & 3 & 3 & 1 & 2 & 2 & 4 & 1 & 2 & 3 & 3 & 3 \\
\hline $\begin{array}{l}\text { Soma dos } 6 \\
\text { principais }\end{array}$ & 91 & 89 & 91 & 78 & 84 & 83 & 81 & 82 & 82 & 80 & 79 & 71 & 85 & 85 & 87 & 87 & 87 \\
\hline
\end{tabular}

Fonte: 1998: Vox Populi (1998); 2002: Ipsos Opinion (2002); 2006: Analítica Consultoria (2006).

Ao longo das campanhas eleitorais de 1998, 2002 e 2006, apenas seis temas principais dominaram as atenções dos eleitores e, juntos, foram mencionados por pelo menos $71 \%$ dos entrevistados nas 17 rodadas de pesquisas nacionais que continham perguntas sobre os maiores problemas do país. Em 1998, os dois problemas capitais, segundo os eleitores, eram saúde e emprego, que receberam entre 35\% e 40\% das menções. Em 2002, o tema do emprego dominou as preocupações dos eleitores; em 2006, a saúde voltou a ser o problema mais importante. Os outros temas de importância foram educação (principalmente em 2006), fome e pobreza, segurança (mais freqüentes em 2002) e corrupção, que nunca recebeu mais que $6 \%$ das menções.

\footnotetext{
${ }^{5}$ Pergunta: Dentre estas áreas de atuação do governo, nas quais o Brasil vem enfrentando problemas de maior ou menor gravidade, qual, na sua opinião, é o problema mais grave do Brasil, atualmente?

${ }^{6}$ Pergunta: Agora, pensando no Brasil como um todo, qual dos problemas desta lista o novo Presidente deveria tentar resolver primeiro durante o seu governo?

${ }^{7}$ Pergunta: Por favor, me diga em qual das áreas que eu vou ler o próximo Presidente deveria dar mais atenção, em primeiro lugar?
} 
A Tabela 16 mostra que, com relação aos candidatos presidenciais do PSDB, não ocorreram mudanças significativas relacionadas às opiniões dos eleitores sobre a capacidade deles para resolver os principais problemas do país. Entre 1998 e 2006, pouco se alteram os percentuais de eleitores que julgam que o candidato do PSDB tem e o do PT não tem tal capacidade. Em 1998, considerando-se apenas os dois principais problemas, 28\% acreditam que FHC seria capaz de resolver o problema da saúde e Lula não o seria, e 24\% tinham a mesma posição com relação ao emprego. Em 2002, esses percentuais foram iguais a $28 \%$ e $20 \%$ e, em 2006 , de $33 \%$ e $30 \%$, respectivamente.

Tabela 16: Opinião dos eleitores sobre qual candidato presidencial tem capacidade para resolver os principais problemas do país (em \%)

\begin{tabular}{|c|l|c|c|c|c|c|c|}
\hline \multirow{2}{*}{ Ano } & \multicolumn{1}{|c|}{$\begin{array}{c}\text { Opinião/Capacidade em } \\
\text { resolver }\end{array}$} & Saúde & Emprego & Educação & $\begin{array}{c}\text { Fome e } \\
\text { pobreza }\end{array}$ & Segurança & Corrupção \\
\hline \hline \multirow{4}{*}{1998} & FHC tem e Lula não tem & 28 & 24 & 29 & 22 & 28 & 21 \\
\cline { 2 - 9 } & Lula tem e FHC não tem & 18 & 24 & 12 & 20 & 15 & 17 \\
\cline { 2 - 8 } & Ambos têm & 17 & 14 & 19 & 18 & 16 & 11 \\
\cline { 2 - 8 } & Nenhum tem & 37 & 37 & 41 & 41 & 41 & 51 \\
\hline \hline \multirow{4}{*}{2002} & Serra tem e Lula não tem & 28 & 20 & 23 & 23 & 21 & 7 \\
\cline { 2 - 8 } & Lula tem e Serra não tem & 31 & 40 & 34 & 34 & 37 & 14 \\
\cline { 2 - 8 } & Ambos têm & 36 & 29 & 36 & 36 & 29 & 7 \\
\cline { 2 - 8 } & Nenhum tem & 6 & 11 & 7 & 7 & 13 & 72 \\
\hline \hline \multirow{3}{*}{2006} & Alckmin tem e Lula não tem & 33 & 30 & 29 & 29 & 31 & 32 \\
\cline { 2 - 8 } & Lula tem e Alckmin não tem & 28 & 40 & 33 & 33 & 30 & 31 \\
\cline { 2 - 8 } & Ambos têm & 31 & 21 & 31 & 31 & 15 & 13 \\
\cline { 2 - 8 } & Nenhum tem & 9 & 9 & 6 & 6 & 25 & 25 \\
\hline
\end{tabular}

Fonte: 1998: Vox Populi (1998), rodada 5, ago./98 (exceto Educação), rodada 1, dez./97; 2002: Ipsos Opinion (2002), rodada 8, out./2002 (exceto Corrupção), rodada 1, abr./2002; 2006: Analítica Consultoria (2006), rodada 6, out./2006.

Entre 1998 e 2002, houve mudanças significativas quanto à opinião dos eleitores sobre a capacidade de Lula para resolver os mais importantes problemas do país. Na eleição de 1998, mais de 38\% dos eleitores acreditavam que ele não seria capaz de solucionar nenhum dos problemas considerados. A partir de 2002, mais de $60 \%$ dos eleitores acreditavam que Lula seria capaz de solucionar os problemas mais importantes, exceto a corrupção e a segurança.

Vale destacar que, em 1998, mais de um terço dos eleitores - até metade deles, no caso da corrupção - acreditava que nenhum dos dois principais candidatos tinha capacidade para resolver os problemas mais 
importantes. A queda nesses índices ocorreu em conjunto com o aumento nas taxas dos que acreditavam que Lula era capaz e que o candidato do PSDB, Serra ou Alckmin, não eram capazes; ou seja, aumentou de maneira significativa a crença de que Lula seria capaz de resolver os problemas do país. Sem dúvida, essa crença contribuiu muito para sua vitória em 2002, quando $49 \%$ acreditavam que Serra seria capaz de resolver o principal problema apontado naquela eleição, o desemprego, enquanto que 69\% acreditavam que Lula não era capaz. O dado mais surpreendente relacionase com a opinião dos eleitores sobre a capacidade de resolver o problema da corrupção. Com efeito, tanto em 1998, quanto em 2002, a maioria acreditava que nem o candidato tucano nem o petista seriam capazes de resolver esse problema. Em 2006, no entanto, mesmo com todos os casos de corrupção que antecederam o pleito, 45\% acreditavam em Alckmin e 44\% que Lula para resolver o problema, e apenas $25 \%$ indicavam que nenhum dos dois teria essa capacidade.

Finalmente, com relação aos dados apresentados na Tabela 16, não se observam diferenças significativas entre Alckmin e Lula no que diz respeito às capacidades atribuídas pelos eleitores. A maior diferença observada é com relação ao emprego, que, em 2006, já havia deixado de ser o problema mais importante. Naquele ano, o candidato do PSDB aparecia como mais capaz que o candidato do PT para resolver o principal problema do país, a saúde.

Os modelos de regressão logística para a ocorrência de intenção de voto no PSDB nas eleições entre 1998 e 2006, tendo como covariáveis as opiniões dos eleitores sobre a capacidade dos candidatos do partido em resolver os principais problemas do país, revelam que a cada eleição tais opiniões se tornam mais importantes. Em 1998, as opiniões sobre a capacidade de Fernando Henrique de resolver os principais problemas do país explicavam apenas $29 \%$ e previam cerca de dois terços das intenções de voto no candidato. Acreditar que FHC era capaz de resolver o desemprego aumentava as chances em 121\%; acreditar que ele resolveria o problema da fome e a da pobreza aumentava as chances em 97\%; acreditar que ele resolveria a saúde aumentava as chances em 93\%; e acreditar que ele resolveria o problema da corrupção aumentava as chances em 37\%. Em 2002, o modelo explica 43\% e 
prevê quase $80 \%$ das intenções de voto. As chances aumentavam expressivamente entre os que acreditavam que Serra era capaz de resolver os problemas da saúde (252\%), do emprego (222\%) e da educação (143\%).

O modelo com melhor ajuste foi observado em 2006, quando foi capaz de explicar $57 \%$ e prever mais de $80 \%$ das intenções de voto no partido. A capacidade mais importante para aumentar as chances de voto no partido foi a de resolver o emprego (238\%), seguida de resolver o problema da fome e da pobreza (184\%), a saúde (152\%), a corrupção (149\%) e a educação (110\%). De maneira geral, a capacidade de resolver o emprego foi mais importante em 1998 e em 2006, e a capacidade de resolver a saúde foi mais importante em 2002.

Quadro 36: Modelo de regressão logística para a ocorrência de voto no PSDB - Capacidade do candidato

\begin{tabular}{|c|c|c|c|c|}
\hline \multicolumn{3}{|c|}{$\begin{array}{rr} & \text { Modelo } 1998 \\
\end{array}$} & Modelo 2002 & Modelo 2006 \\
\hline \multicolumn{5}{|c|}{ VARIÁVEIS DAS CAPACIDADES DO CANDIDATO } \\
\hline & \multirow{2}{*}{ 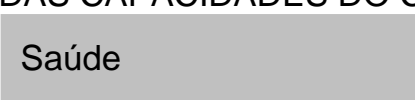 } & $1,926\left(^{* \star}\right)$ & $3,521(* \star)$ & $2,519(* \star)$ \\
\hline & & $(0,12)$ & $(0,28)$ & $(0,18)$ \\
\hline & \multirow{2}{*}{ Emprego } & $2,217(* \star)$ & $3,224(* \star)$ & $3,376\left({ }^{* \star}\right)$ \\
\hline & & $(0,12)$ & $(0,16)$ & $(0,16)$ \\
\hline & \multirow{2}{*}{ Educação } & & $2,434\left({ }^{* \star}\right)$ & $\left.2,0955^{(\star *}\right)$ \\
\hline & & & $(0,26)$ & $(0,18)$ \\
\hline & \multirow{2}{*}{ Fome e pobreza } & $1,968\left(^{* \star}\right)$ & 1,439 & $2,841(* \star)$ \\
\hline & & $(0,12)$ & $(0,19)$ & $(0,15)$ \\
\hline & \multirow{2}{*}{ Segurança } & 1,171 & 1,738 & 1,316 \\
\hline & & $(0,12)$ & $(0,18)$ & $(0,15)$ \\
\hline & \multirow{2}{*}{ Corrupção } & $1,368(* *)$ & & $2,488(* \star)$ \\
\hline & & $(0,12)$ & & $(0,15)$ \\
\hline \multicolumn{2}{|l|}{ 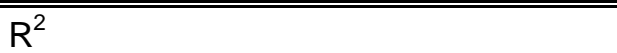 } & 0,29 & 0,43 & 0,57 \\
\hline \multicolumn{2}{|c|}{ N } & 3.195 & 2.004 & 2.400 \\
\hline \multicolumn{2}{|c|}{ Casos previstos corretamente } & $73 \%$ & $78 \%$ & $83 \%$ \\
\hline \multicolumn{2}{|c|}{ Votos no PSDB previstos corretamente } & $66 \%$ & $79 \%$ & $84 \%$ \\
\hline \multicolumn{2}{|c|}{ Previsões de voto no PSDB corretas } & $71 \%$ & $62 \%$ & $74 \%$ \\
\hline \multicolumn{2}{|c|}{ Chance na base } & $21 \%$ & $2 \%$ & $2 \%$ \\
\hline
\end{tabular}

Notas: $\left({ }^{\star}\right) p<0,05 .\left({ }^{\star \star}\right) p<0,01$.

Fonte: 1998: Vox Populi (1998); 2002: Ipsos Opinion (2002); 2006: Analítica Consultoria (2006).

No caso do PT, os modelos com as opiniões dos eleitores sobre a capacidade de Lula para resolver os principais problemas do país explicam e prevêem melhor a intenção de voto no partido do que os modelos para o PSDB. Em 1998, o modelo explica 35\% e prevê 56\% das intenções de voto; esses índices aumentam para 64\% e 95\% em 2002 e para 66\% e 91\% em 
2006. Ou seja: assim como para o PSDB, conhecer as capacidades de resolução de problemas que os eleitores atribuíam ao candidato petista a cada ano se torna mais importante para a decisão de voto no PT.

Em todos os modelos, a crença na capacidade de Lula para resolver o emprego foi a variável que mais aumentou as chances de voto no PT, variando entre 139\% em 1998, 455\% em 2002 e 257\% em 2006. Nessas condições, é possível dizer que a questão do emprego fez grande diferença para a vitória de Lula em 2002. Essa era a principal preocupação do brasileiro naquele ano, e Lula era considerado o candidato mais capaz de resolver esse problema - entre os que acreditavam nisso, suas chances de intenção voto aumentavam quase cinco vezes.

Quadro 37: Modelo de regressão logística para a ocorrência de voto no PT - Capacidade do candidato

\begin{tabular}{|c|c|c|c|c|}
\hline \multicolumn{3}{|c|}{$\begin{array}{lr}\text { Modelo } 1998 \\
\end{array}$} & Modelo 2002 & Modelo 2006 \\
\hline \multicolumn{5}{|c|}{ VARIÁVEIS DAS CAPACIDADES DO CANDIDATO } \\
\hline & \multirow{2}{*}{ Saúde } & $2,220\left(^{* *}\right)$ & $3,823(* \star)$ & $2,983(* \star)$ \\
\hline & & $(0,15)$ & $(0,2)$ & $(0,15)$ \\
\hline & \multirow{2}{*}{ Emprego } & $2,394(* \star)$ & $5,548(\star \star)$ & $3,573(* \star)$ \\
\hline & & $(0,16)$ & $(0,19)$ & $(0,16)$ \\
\hline & \multirow{2}{*}{ Educação } & & $3,293(* \star)$ & $3,341\left(^{* \star}\right)$ \\
\hline & & & $(0,25)$ & $(0,18)$ \\
\hline & \multirow{2}{*}{ Fome e pobreza } & 1,337 & $2,107(* \star)$ & $2,160(* \star)$ \\
\hline & & $(0,16)$ & $(0,24)$ & $(0,19)$ \\
\hline & \multirow{2}{*}{ Segurança } & $\left.1,817^{(* *}\right)$ & $\left.1,7099^{(* *}\right)$ & $\left.1,893^{(* *}\right)$ \\
\hline & & $(0,14)$ & $(0,21)$ & $(0,17)$ \\
\hline & \multirow{2}{*}{ Corrupção } & $\left.1,833^{(* *}\right)$ & & $\left.1,870^{(* *}\right)$ \\
\hline & & $(0,14)$ & & $(0,17)$ \\
\hline \multicolumn{2}{|l|}{ 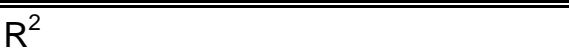 } & 0,35 & 0,64 & 0,66 \\
\hline \multicolumn{2}{|c|}{$\mathrm{N}$} & 3.195 & 2.004 & 2.400 \\
\hline \multicolumn{2}{|c|}{ Casos previstos corretamente } & $83 \%$ & $86 \%$ & $87 \%$ \\
\hline \multicolumn{2}{|c|}{ Votos no PT previstos corretamente } & $56 \%$ & $95 \%$ & $91 \%$ \\
\hline \multicolumn{2}{|c|}{ Previsões de voto no PT corretas } & $65 \%$ & $84 \%$ & $86 \%$ \\
\hline \multicolumn{2}{|c|}{ Chance na base } & $6 \%$ & $3 \%$ & $4 \%$ \\
\hline
\end{tabular}

Notas: $\left(^{\star}\right) p<0,05 .\left(^{\star \star}\right) p<0,01$.

Fonte: 1998: Vox Populi (1998); 2002: Ipsos Opinion (2002); 2006: Analítica Consultoria (2006).

\subsection{Considerações finais}

Até aqui, examinamos a maioria das hipóteses mais importantes relacionadas ao comportamento eleitoral que sugerem as literaturas nacional e 
internacional. Consideramos a hipótese do comportamento eleitoral baseado em características demográficas e socioeconômicas, defendidas pela escola sociológica de Colúmbia (Berelson, Lazarsfeld \& McPhee, 1954, e Lazarsfeld, Berelson \& Gaudet, 1948) e também exploradas por Castro (1994), no caso brasileiro. Testamos a hipótese do comportamento eleitoral baseado em posições partidárias e ideológicas, sugerida principalmente pela escola sócio-psicológica de Michigan (Campbell et al., 1960) e examinada, no caso do Brasil, pela tese de Singer (2000). Por fim, foram testadas as hipóteses sugeridas pela teoria da escolha racional (Downs, 1999, Fiorina, 1981, Key, 1966, e Popkin, 1994) e pela tese de Carreirão (2002), que defendem a superioridade explicativa de aspectos mais conjunturais da decisão de voto, em especial quando relacionados à avaliação de desempenho do governo e às características dos candidatos.

Antes de procedermos à análise de todas essas variáveis em conjunto, é necessário comparar o poder explicativo dos diversos modelos apresentados até aqui, para que possamos apontar qual dos conjuntos de variáveis isoladamente explica melhor o voto presidencial no Brasil (ver Quadro 38).

Quadro 38: Comparativo dos $\mathbf{R}^{\mathbf{2}}$ obtidos nos modelos
\begin{tabular}{|l|c|c|c|c|}
\hline $\mathbf{R}^{2}$ de Nagelkerk para os modelos do PSDB & $\mathbf{1 9 9 4}$ & $\mathbf{1 9 9 8}$ & $\mathbf{2 0 0 2}$ & $\mathbf{2 0 0 6}$ \\
\hline Conjunto de variáveis demográficas e socioeconômicas & 0,01 & 0,02 & 0,03 & 0,1 \\
\hline Conjunto de variáveis partidárias & 0,2 & 0,11 & 0,2 & 0,16 \\
\hline Conjunto de variáveis ideológicas & $\mathrm{n} / \mathrm{d}$ & 0,04 & 0,05 & 0 \\
\hline Conjunto de variáveis com efeitos de longo prazo & 0,22 & 0,2 & 0,29 & 0,25 \\
\hline Conjunto de variáveis de avaliação do governo & 0,13 & 0,38 & 0,23 & 0,4 \\
\hline Conjunto de variáveis com as qualidades dos candidatos & $\mathrm{n} / \mathrm{d}$ & 0,42 & 0,58 & 0,64 \\
\hline Conjunto de variáveis com as capacidades dos candidatos & $\mathrm{n} / \mathrm{d}$ & 0,29 & 0,43 & 0,57 \\
\hline $\mathbf{R}^{2}$ de Nagelkerk para os modelos do PT & $\mathbf{1 9 9 4}$ & $\mathbf{1 9 9 8}$ & $\mathbf{2 0 0 2}$ & $\mathbf{2 0 0 6}$ \\
\hline Conjunto de variáveis demográficas e socioeconômicas & 0,03 & 0,02 & 0,02 & 0,13 \\
\hline Conjunto de variáveis partidárias & 0,36 & 0,22 & 0,14 & 0,18 \\
\hline Conjunto de variáveis ideológicas & $\mathrm{n} / \mathrm{d}$ & 0,01 & 0,06 & 0 \\
\hline Conjunto de variáveis com efeitos de longo prazo & 0,38 & 0,25 & 0,2 & 0,28 \\
\hline Conjunto de variáveis de avaliação do governo & 0,06 & 0,16 & 0,18 & 0,45 \\
\hline Conjunto de variáveis com as qualidades dos candidatos & $\mathrm{n} / \mathrm{d}$ & 0,49 & 0,71 & 0,72 \\
\hline Conjunto de variáveis com as capacidades dos candidatos & $\mathrm{n} / \mathrm{d}$ & 0,35 & 0,64 & 0,66 \\
\hline
\end{tabular}

De todos os modelos analisados para o PSDB e para o PT, os que alcançaram maior poder explicativo foram aqueles que continham covariáveis referentes a aspectos de curto prazo da decisão de voto, especialmente os relacionados às qualidades dos candidatos. Contudo, a comparação do poder 
explicativo de cada modelo não deve nos levar à conclusão de que esse conjunto de variáveis é o mais importante, antes que possamos verificar todos os modelos conjuntamente. 


\section{Capítulo 4. Modelos gerais de decisão de voto}

Até agora foram examinados detidamente os possíveis efeitos sobre a ocorrência de intenção de voto no PSDB e no PT das variáveis que representam os fatores de longo e curto prazo da decisão de voto. Verificouse que, observadas isoladamente, as variáveis, em sua maioria, apresentaram-se acompanhadas de alterações significativas nas chances de voto de cada partido. Esses efeitos são mais fracos com relação às características demográficas e socioeconômicas e mais fortes com relação às opiniões sobre os candidatos.

Se esses resultados conferem legitimidade à escolha das variáveis feitas até aqui, ainda não permitem testar com a devida consistência a hipótese central dessa pesquisa, qual seja, que os fatores de curto prazo são mais determinantes que os de longo prazo para as chances de intenção de voto no PSDB e no PT. Para tanto, é necessário observar simultaneamente todas as variáveis independentes, a fim de que seus efeitos sejam analisados em conjunto e possam se controlar uns aos outros. Com isso, será possível verificar quais variáveis mantêm sua associação com o comportamento eleitoral e quais a perdem, assim como avaliar quais estão relacionadas com as maiores probabilidades de voto em cada um dos partidos.

O procedimento adotado para realizar o teste dessa hipótese é o mesmo que foi adotado desde o início deste trabalho, isto é, a elaboração de modelos multivariados de regressão logística. Como ressalvamos, esses modelos permitem a análise simultânea de diversas variáveis independentes, qualidade fundamental para o teste aqui proposto. Esse procedimento permite encontrar, entre as diversas combinações possíveis de variáveis, aquelas que elevem ao máximo a capacidade explicativa e preditiva dos modelos, proporcionando que sejam identificados, conforme exige a hipótese, quais fatores são mais determinantes para o comportamento eleitoral nas eleições presidenciais.

Assim como nas regressões anteriores, todos os modelos gerais que são apresentados foram elaborados e seus resultados calculados por meio 
do programa SPSS, versão 14. Mas, antes de apresentar esses resultados, cabe especificar brevemente como será feita a modelagem.

A. Fatores de longo prazo na decisão eleitoral: características demográficas e socioeconômicas - Sob essa classificação estão as variáveis referentes às condições de vida mais objetivas dos eleitores.

- Sexo: mulher $=0$ e homem $=1$.

- Idade: cinco faixas etárias: mais jovens $=0$ até mais velhos $=4$.

- Escolaridade: até fundamental completo $=0$ e médio incompleto ou mais $=1$.

- Renda familiar: até cinco salários mínimos $=0$ e acima de cinco salários mínimos $=1$.

- Participação na população economicamente ativa: não-PEA = 0 e PEA $=1$.

- Etnia: não-branco $=0$ e branco $=1$.

- Religião: não-católico $=0$ e católico $=1$.

- Região do país: a referência em alguns modelos é a região Norte e em outros a região Norte mais o Centro-Oeste; as outras regiões são representadas por variáveis indicadoras.

- Local de moradia: nos modelos baseados nas rodadas 1 e 5 do Vox Populi para 1998 , zona rural $=0$ e zona urbana $=1$; no modelo baseado na rodada 2 do Vox Populi para 1998, não capital e não região metropolitana $=0$ e capital ou região metropolitana $=1$; nos modelos baseados nos dados do Estudo Eleitoral Brasileiro (Eseb) para 2002, não capital $=0$ e capital $=1$; nos modelos baseados nos dados da Analítica Consultoria para 2006, a referência é não capital, nem região metropolitana $=0$, capital e região metropolitana são representadas por variáveis indicadoras.

Vimos no primeiro capítulo que essas variáveis são responsáveis por impacto estatisticamente significante nas chances de voto dos partidos em ao menos uma das eleições analisadas. Sexo, escolaridade, renda familiar, etnia, religião e região do país, consideradas tanto isoladamente, como em conjunto com as outras características demográficas e socioeconômicas, são as que 
apresentam maiores associações com o comportamento eleitoral, ainda que não tenha sido possível identificar bases de apoio sólidas aos partidos. No modelo geral, será possível verificar se as conclusões provisórias que fizemos no primeiro capítulo se sustentam.

B. Fatores de longo prazo na decisão eleitoral: características políticas e ideológicas - Sob esta classificação estão aquelas variáveis referentes às posições partidárias e ideológicas dos eleitores.

- Preferência partidária: eleitores sem preferência pelos quatro grandes partidos $=0$ e variáveis indicadoras de preferência com PSDB, PT, PMDB e PFL.

- Ideologia: nos modelos baseados nos dados das rodadas 2 e 5 do Vox Populi para 1998, são utilizadas como proxy de ideologia as opiniões dos eleitores sobre as privatizações realizadas no governo de Fernando Henrique Cardoso, assim operacionalizadas: opiniões contrárias à privatização: -1 , opiniões neutras $=0$ e opiniões favoráveis $=1$; nos modelos para 2002, baseados em dados do Eseb, a variável utilizada é o autoposicionamento ideológico em uma escala de 0 até 10, na qual 0 representa extrema esquerda e 10 representa extrema direita, assim operacionalizada: valores entre 0 e $3=$ esquerda $=-1$, valores entre 4 e $6=$ centro $=0$ e valores entre 7 e $10=$ direita $=1$; nos modelos baseados nos dados da rodada 3 da Analítica Consultoria para a eleição de 2006, a proxy de ideologia adotada é a opinião dos eleitores sobre a melhor forma de combater o crime e a violência, assim operacionalizada: melhorar a educação e os programas sociais de ajuda aos mais pobres $=0$ e construir mais presídios e tratar os presos com mais rigidez $=1$.

Vimos no Capítulo 2 que essas variáveis exercem impacto significativo sobre o comportamento eleitoral. Contudo, contrariando as expectativas com relação ao aumento da importância do partidarismo ao longo do período, parece ter havido uma erosão das bases de apoio partidárias. Com relação à ideologia, observamos que é estatisticamente significante, exceto em 2006, quando a proxy adotada parece não captar adequadamente o conceito. De forma geral, as variáveis partidárias e ideológicas exerceram impacto maior sobre o comportamento eleitoral do que as demográficas e socioeconômicas. 
No modelo geral será possível verificar se as conclusões parciais do segundo capítulo se sustentam.

C. Fatores de curto prazo na decisão eleitoral: avaliação de governo e dos candidatos.

- Avaliação de governo: no modelo para a eleição de 1994, foi utilizado como proxy de avaliação do governo a avaliação do Plano Real, que foi operacionalizada da mesma forma que a avaliação do governo, ou seja: negativa $=-1$, regular $=0$ e positiva $=1$.

- Avaliação dos candidatos: o candidato não tem a principal qualidade que um presidente deve ter na opinião da maior parcela dos eleitores $=0$ e o candidato tem essa qualidade $=1$ (as principais qualidades foram: em 1998, honestidade; em 2002, fazer mais pelos pobres; em 2006, combater a corrupção); o candidato não tem capacidade para resolver o principal problema do país na opinião da maior parcela dos eleitores $=0$ e 0 candidato tem essa capacidade $=1$ (os principais problemas do país foram: em 1998, saúde; em 2002, emprego; em 2006, saúde).

Vimos no Capítulo 3 que essas variáveis exercem impacto estatisticamente significativo sobre o comportamento eleitoral. Quando analisadas isoladamente, tanto a avaliação do governo, quanto a avaliação dos candidatos resultam em modelos que explicam e prevêem melhor o comportamento eleitoral. Resta saber se, quando analisadas com maior parcimônia e em conjunto com as demais variáveis, essa capacidade explicativa e preditiva se mantém.

O eleitor-base dos modelos apresentados é uma mulher, jovem, com baixa escolaridade, baixa renda, fora da PEA, não branca, não católica, moradora do interior da região Norte (ou Norte/Centro-Oeste), sem preferência pelos grandes partidos, posicionada no centro do espectro ideológico, com avaliação regular do governo e que não acredita que os candidatos do PSDB e do PT têm a qualidade mais importante para ser presidente nem capacidade para resolver o problema mais importante do país. 


\subsection{Modelos gerais de regressão logística multivariados para o PSDB}

Quadro 39: Modelos gerais de regressão logística para a ocorrência de voto no PSDB

\begin{tabular}{|c|c|c|c|c|c|c|c|c|c|c|}
\hline & $\begin{array}{c}\text { Modelo } \\
1994\end{array}$ & $\begin{array}{l}\text { Modelo } \\
1998 \text { r1 }\end{array}$ & $\begin{array}{l}\text { Modelo } \\
1998 \text { r2 }\end{array}$ & $\begin{array}{l}\text { Modelo } \\
1998 \text { r5 }\end{array}$ & $\begin{array}{c}\text { Modelo } \\
2002 \\
1^{\circ} \text { turno } \\
\mathrm{e} \\
\end{array}$ & $\begin{array}{c}\text { Modelo } \\
2002 \\
2^{\circ} \text { turno } \\
\mathrm{e} \\
\end{array}$ & $\begin{array}{c}\text { Modelo } \\
2006 \\
1^{\circ} \text { turno } \\
\mathrm{r} 1 \\
\end{array}$ & $\begin{array}{c}\text { Modelo } \\
2006 \\
1^{\circ} \text { turno } \\
r 3 \\
\end{array}$ & $\begin{array}{c}\text { Modelo } \\
2006 \\
1^{\circ} \text { turno } \\
\text { r3 } \\
\end{array}$ & $\begin{array}{c}\text { Modelo } \\
2006 \\
2^{\circ} \text { turno } \\
\text { r6 } \\
\end{array}$ \\
\hline \multicolumn{11}{|c|}{ VARIÁVEIS DEMOGRÁFICAS E SOCIOECONÔMICAS } \\
\hline Sexo & $\begin{array}{c}1,1 \\
(0,1)\end{array}$ & $\begin{array}{c}0,876 \\
(0,1)\end{array}$ & $\begin{array}{c}1,234\left(^{*}\right) \\
(0,1)\end{array}$ & $\begin{array}{c}0,997 \\
(0,1)\end{array}$ & $\begin{array}{c}0,83 \\
(0,15)\end{array}$ & $\begin{array}{c}0,745\left(^{*}\right) \\
(0,14)\end{array}$ & $\begin{array}{l}0,911 \\
(0,22)\end{array}$ & $\begin{array}{l}0,676 \\
(0,25)\end{array}$ & $\begin{array}{l}1,062 \\
(0,25)\end{array}$ & $\begin{array}{l}0,874 \\
(0,14)\end{array}$ \\
\hline Idade & $\begin{array}{l}1,009 \\
(0,04)\end{array}$ & $\begin{array}{c}0,914\left({ }^{* \star}\right) \\
(0,03)\end{array}$ & $\begin{array}{c}0,933\left({ }^{*}\right) \\
(0,03)\end{array}$ & $\begin{array}{l}0,952 \\
(0,03)\end{array}$ & $\begin{array}{c}1,09 \\
(0,06)\end{array}$ & $\begin{array}{l}1,094 \\
(0,05)\end{array}$ & $\begin{array}{l}0,876 \\
(0,09)\end{array}$ & $\begin{array}{c}1,074 \\
(0,1)\end{array}$ & $\begin{array}{c}0,875 \\
(0,1)\end{array}$ & $\begin{array}{l}1,042 \\
(0,06)\end{array}$ \\
\hline Escolaridade & $\begin{array}{l}0,841 \\
(0,12)\end{array}$ & $\begin{array}{l}0,866 \\
(0,11)\end{array}$ & $\begin{array}{l}0,897 \\
(0,11)\end{array}$ & $\begin{array}{c}0,82 \\
(0,11)\end{array}$ & $\begin{array}{l}1,024 \\
(0,18)\end{array}$ & $\begin{array}{l}0,929 \\
(0,16)\end{array}$ & $\begin{array}{l}1,307 \\
(0,23)\end{array}$ & $\begin{array}{l}1,515 \\
(0,27)\end{array}$ & $\begin{array}{l}0,915 \\
(0,27)\end{array}$ & $\begin{array}{c}1,21 \\
(0,15)\end{array}$ \\
\hline Renda & $\begin{array}{l}1,211 \\
(0,11)\end{array}$ & $\begin{array}{l}0,944 \\
(0,11)\end{array}$ & $\begin{array}{l}1,074 \\
(0,11)\end{array}$ & $\begin{array}{l}1,195 \\
(0,11)\end{array}$ & $\begin{array}{c}1,734\left({ }^{\star \star}\right) \\
(0,17)\end{array}$ & $\begin{array}{c}2,201\left({ }^{\star *}\right) \\
(0,15)\end{array}$ & $\begin{array}{l}1,077 \\
(0,31)\end{array}$ & $\begin{array}{c}1,1 \\
(0,35)\end{array}$ & $\begin{array}{l}0,843 \\
(0,33)\end{array}$ & $\begin{array}{l}1,214 \\
(0,19)\end{array}$ \\
\hline PEA & & & & $\begin{array}{c}0,817\left(^{*}\right) \\
(0,1)\end{array}$ & $\begin{array}{l}0,811 \\
(0,17)\end{array}$ & $\begin{array}{l}1,077 \\
(0,16)\end{array}$ & $\begin{array}{l}1,274 \\
(0,25)\end{array}$ & $\begin{array}{l}0,841 \\
(0,27)\end{array}$ & $\begin{array}{l}0,824 \\
(0,28)\end{array}$ & $\begin{array}{l}0,961 \\
(0,15)\end{array}$ \\
\hline Branco & $\begin{array}{c}1,001 \\
(0,1)\end{array}$ & & & & $\begin{array}{c}1,439\left(^{*}\right) \\
(0,16)\end{array}$ & $\begin{array}{l}1,007 \\
(0,14)\end{array}$ & $\begin{array}{c}1,28 \\
(0,23)\end{array}$ & $\begin{array}{l}1,148 \\
(0,25)\end{array}$ & $\begin{array}{l}1,512 \\
(0,25)\end{array}$ & \\
\hline Católico & & & & & $\begin{array}{c}1,820\left({ }^{* *}\right) \\
(0,16)\end{array}$ & $\begin{array}{l}1,036 \\
(0,14)\end{array}$ & & $\begin{array}{l}0,925 \\
(0,27)\end{array}$ & $\begin{array}{l}0,898 \\
(0,27)\end{array}$ & $\begin{array}{l}1,217 \\
(0,15)\end{array}$ \\
\hline Nordeste & & $\begin{array}{c}0,949 \\
(0,2)\end{array}$ & $\begin{array}{c}0,635\left(^{*}\right) \\
(0,22)\end{array}$ & $\begin{array}{c}0,532(* *) \\
(0,21)\end{array}$ & $\begin{array}{l}0,675 \\
(0,39)\end{array}$ & $\begin{array}{l}0,642 \\
(0,34)\end{array}$ & $\begin{array}{l}0,862 \\
(0,36)\end{array}$ & $\begin{array}{c}0,601 \\
(0,4)\end{array}$ & $\begin{array}{l}1,236 \\
(0,44)\end{array}$ & $\begin{array}{l}1,023 \\
(0,29)\end{array}$ \\
\hline Centro-oeste & & $\begin{array}{c}1,52 \\
(0,24)\end{array}$ & $\begin{array}{l}0,831 \\
(0,26)\end{array}$ & $\begin{array}{l}1,054 \\
(0,26)\end{array}$ & $\begin{array}{l}1,407 \\
(0,43)\end{array}$ & $\begin{array}{l}0,665 \\
(0,39)\end{array}$ & & & & $\begin{array}{c}2,090\left(^{*}\right) \\
(0,33)\end{array}$ \\
\hline Sudeste & & $\begin{array}{l}1,248 \\
(0,19)\end{array}$ & $\begin{array}{l}0,803 \\
(0,21)\end{array}$ & $\begin{array}{c}\left.0,478{ }^{(\star *}\right) \\
(0,2)\end{array}$ & $\begin{array}{l}1,177 \\
(0,37)\end{array}$ & $\begin{array}{l}0,925 \\
(0,33)\end{array}$ & $\begin{array}{c}2,391\left({ }^{\star *}\right) \\
(0,32)\end{array}$ & $\begin{array}{l}1,077 \\
(0,35)\end{array}$ & $\begin{array}{l}1,824 \\
(0,41)\end{array}$ & $\begin{array}{l}1,225 \\
(0,29)\end{array}$ \\
\hline Sul & & $\begin{array}{l}0,682 \\
(0,22)\end{array}$ & $\begin{array}{l}0,859 \\
(0,23)\end{array}$ & $\begin{array}{c}\left.0,558{ }^{(\star \star}\right) \\
(0,23)\end{array}$ & $\begin{array}{c}0,983 \\
(0,4)\end{array}$ & $\begin{array}{l}0,796 \\
(0,36)\end{array}$ & $\begin{array}{l}1,361 \\
(0,38)\end{array}$ & $\begin{array}{l}0,631 \\
(0,43)\end{array}$ & $\begin{array}{l}1,102 \\
(0,47)\end{array}$ & $\begin{array}{c}2,014\left(^{*}\right) \\
(0,31)\end{array}$ \\
\hline Zona urbana & & $\begin{array}{l}1,128 \\
(0,12)\end{array}$ & & $\begin{array}{c}0,9 \\
(0,12)\end{array}$ & & & & & & \\
\hline $\begin{array}{l}\text { Capital e região } \\
\text { metropolitana }\end{array}$ & & & $\begin{array}{l}0,958 \\
(0,11)\end{array}$ & & & & & & & \\
\hline Capital & & & & & $\begin{array}{l}0,915 \\
(0,16)\end{array}$ & $\begin{array}{c}1,15 \\
(0,15)\end{array}$ & $\begin{array}{l}1,227 \\
(0,26)\end{array}$ & $\begin{array}{c}0,485\left(^{*}\right) \\
(0,31)\end{array}$ & $\begin{array}{l}0,599 \\
(0,31)\end{array}$ & $\begin{array}{c}0,77 \\
(0,16)\end{array}$ \\
\hline $\begin{array}{l}\text { Região } \\
\text { metropolitana }\end{array}$ & & & & & & & $\begin{array}{l}0,652 \\
(0,33) \\
\end{array}$ & $\begin{array}{c}0,84 \\
(0,39) \\
\end{array}$ & $\begin{array}{l}1,147 \\
(0,35) \\
\end{array}$ & $\begin{array}{l}0,768 \\
(0,23) \\
\end{array}$ \\
\hline \multicolumn{11}{|l|}{ VARIÁVEIS POLÍTICAS } \\
\hline 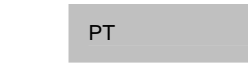 & $\begin{array}{c}0,065\left({ }^{* \star}\right) \\
(0,29)\end{array}$ & $\begin{array}{c}0,238(* *) \\
(0,2)\end{array}$ & $\begin{array}{c}0,113\left({ }^{* *}\right) \\
(0,33)\end{array}$ & & $\begin{array}{c}0,117(* *) \\
(0,31)\end{array}$ & $\begin{array}{c}0,069(* \star) \\
(0,3)\end{array}$ & $\begin{array}{c}0,141(* *) \\
(0,5)\end{array}$ & $\begin{array}{c}0,306\left(^{*}\right) \\
(0,56)\end{array}$ & $\begin{array}{c}0,221\left(^{*}\right) \\
(0,75)\end{array}$ & \\
\hline PSDB & $\begin{array}{c}7,963\left({ }^{* *}\right) \\
(0,29)\end{array}$ & $\begin{array}{c}3,406(* *) \\
(0,25)\end{array}$ & $\begin{array}{c}\left.5,439{ }^{(*}\right) \\
(0,27)\end{array}$ & & $\begin{array}{c}3,728\left({ }^{\star *}\right) \\
(0,25)\end{array}$ & $\begin{array}{c}3,027\left({ }^{\star *}\right) \\
(0,25)\end{array}$ & $\begin{array}{c}5,693\left({ }^{*}\right) \\
(0,39)\end{array}$ & $\begin{array}{c}6,821(\star *) \\
(0,49)\end{array}$ & $\begin{array}{c}6,286\left({ }^{*}\right) \\
(0,43)\end{array}$ & \\
\hline PMDB & $\begin{array}{l}1,226 \\
(0,14)\end{array}$ & $\begin{array}{c}1,413(*) \\
(0,16)\end{array}$ & $\begin{array}{c}\left.1,486{ }^{(*}\right) \\
(0,15)\end{array}$ & & $\begin{array}{l}1,439 \\
(0,23)\end{array}$ & $\begin{array}{l}0,864 \\
(0,22)\end{array}$ & $\begin{array}{c}1,16 \\
(0,38)\end{array}$ & $\begin{array}{c}2,559\left(^{*}\right) \\
(0,42)\end{array}$ & $\begin{array}{l}1,411 \\
(0,42)\end{array}$ & \\
\hline PFL & $\begin{array}{c}3,818\left({ }^{(\star)}\right) \\
(0,34) \\
\end{array}$ & $\begin{array}{c}2,472\left({ }^{* *}\right) \\
(0,28) \\
\end{array}$ & $\begin{array}{c}\left.3,171{ }^{(\star *}\right) \\
(0,26) \\
\end{array}$ & & $\begin{array}{r}1,43 \\
(0,31) \\
\end{array}$ & $\begin{array}{l}1,357 \\
(0,29) \\
\end{array}$ & $\begin{array}{l}2,281 \\
(0,75) \\
\end{array}$ & $\begin{array}{c}2,405 \\
(0,9) \\
\end{array}$ & $\begin{array}{l}3,458 \\
(0,65) \\
\end{array}$ & \\
\hline \multicolumn{11}{|l|}{ VARIÁVEIS IDEOLÓGICAS } \\
\hline Ideologia & & & $\begin{array}{c}1,422(* \star) \\
(0,07) \\
\end{array}$ & $\begin{array}{c}1,399\left(^{\star \star}\right) \\
(0,06) \\
\end{array}$ & $\begin{array}{l}1,185 \\
(0,09) \\
\end{array}$ & $\begin{array}{c}1,425\left(^{\star \star}\right) \\
(0,08) \\
\end{array}$ & & $\begin{array}{l}1,413 \\
(0,25) \\
\end{array}$ & $\begin{array}{l}1,165 \\
(0,26) \\
\end{array}$ & \\
\hline \multicolumn{11}{|c|}{ AVALIAÇÃO DE GOVERNO } \\
\hline $\begin{array}{l}\text { Avaliação do } \\
\text { governo }\end{array}$ & $\begin{array}{c}3,036\left(^{* \star}\right) \\
(0,1) \\
\end{array}$ & $\begin{array}{c}4,053\left({ }^{* \star}\right) \\
(0,08) \\
\end{array}$ & $\begin{array}{c}8,198\left(^{\star \star *}\right) \\
(0,09) \\
\end{array}$ & $\begin{array}{c}5,036\left(^{* *}\right) \\
(0,08) \\
\end{array}$ & $\begin{array}{c}1,614\left(^{\star \star}\right) \\
(0,08) \\
\end{array}$ & $\begin{array}{c}1,569\left(^{(\star}\right) \\
(0,07) \\
\end{array}$ & $\begin{array}{c}\left.0,3511^{(*}\right) \\
(0,21) \\
\end{array}$ & $\begin{array}{c}0,413\left(^{* *}\right) \\
(0,16) \\
\end{array}$ & $\begin{array}{c}0,265\left(^{(\star *}\right) \\
(0,18) \\
\end{array}$ & $\begin{array}{c}\left.0,143{ }^{(\star *}\right) \\
(0,11) \\
\end{array}$ \\
\hline \multicolumn{11}{|c|}{ AVALIAÇÃO DO CANDIDATO } \\
\hline $\begin{array}{l}\text { Principal } \\
\text { qualidade }\end{array}$ & & $\begin{array}{c}2,345\left({ }^{\star \star}\right) \\
(0,11)\end{array}$ & & $\begin{array}{c}1,945\left({ }^{\star *}\right) \\
(0,11)\end{array}$ & $\begin{array}{c}4,423\left({ }^{*}\right) \\
(0,16)\end{array}$ & $\begin{array}{c}3,544\left({ }^{\star *}\right) \\
(0,16)\end{array}$ & $\begin{array}{c}4,288\left({ }^{(\star)}\right) \\
(0,23)\end{array}$ & $\begin{array}{c}7,140(* \star) \\
(0,25)\end{array}$ & & $\begin{array}{c}\left.7,004{ }^{(*}\right) \\
(0,14)\end{array}$ \\
\hline $\begin{array}{l}\text { Principal } \\
\text { problema }\end{array}$ & & $\begin{array}{c}3,281(* \star) \\
(0,1) \\
\end{array}$ & & $\begin{array}{c}2,641\left(^{\star \star}\right) \\
(0,1) \\
\end{array}$ & $\begin{array}{c}2,442\left(^{(\star *}\right) \\
(0,17) \\
\end{array}$ & $\begin{array}{c}3,001\left(^{\star \star}\right) \\
(0,16) \\
\end{array}$ & $\begin{array}{c}4,027\left(^{(\star}\right) \\
(0,25) \\
\end{array}$ & & $\begin{array}{c}\left.6,440{ }^{(*}\right) \\
(0,33) \\
\end{array}$ & $\begin{array}{c}\left.6,763{ }^{(\star \star}\right) \\
(0,18) \\
\end{array}$ \\
\hline $\mathrm{R}^{2}$ & 0,3 & 0,49 & 0,51 & 0,47 & 0,4 & 0,42 & 0,56 & 0,46 & 0,41 & 0,64 \\
\hline $\begin{array}{l}\mathrm{N} \\
\text { Casos previstos }\end{array}$ & 2.108 & 3.156 & 3.051 & 3.152 & 1.862 & 1.862 & 913 & 712 & 695 & 2.203 \\
\hline $\begin{array}{l}\text { corretamente } \\
\text { Votos no PSDB previstos }\end{array}$ & $68 \%$ & $79 \%$ & $81 \%$ & $77 \%$ & $85 \%$ & $83 \%$ & $85 \%$ & $84 \%$ & $86 \%$ & $85 \%$ \\
\hline $\begin{array}{l}\text { corretamente } \\
\text { Previsões de voto no }\end{array}$ & $88 \%$ & $70 \%$ & $67 \%$ & $74 \%$ & $44 \%$ & $51 \%$ & $68 \%$ & $52 \%$ & $45 \%$ & $75 \%$ \\
\hline PSDB corretas & $61 \%$ & $76 \%$ & $75 \%$ & $74 \%$ & $68 \%$ & $74 \%$ & $74 \%$ & $67 \%$ & $69 \%$ & $83 \%$ \\
\hline Chance na base & $27 \%$ & $19 \%$ & $6 \%$ & $35 \%$ & $6 \%$ & $17 \%$ & $4 \%$ & $10 \%$ & $5 \%$ & $6 \%$ \\
\hline
\end{tabular}

Notas: $\left(^{\star}\right) p<0,05 .\left({ }^{* \star}\right) p<0,01$.

Fonte: 1994: Datafolha (1994); 1998: Vox Populi (1998); 2002: Almeida et al. (2002) e Ipsos

Opinion (2002); 2006: Analítica Consultoria (2006). 
O modelo para a eleição de 1994 é o que contém o menor número de variáveis, porque o banco de dados disponível é muito limitado. Ainda assim, inclui cinco variáveis demográficas e socioeconômicas, as quatro variáveis indicadoras de preferência partidária e a variável relacionada à avaliação do governo. São quatro as variáveis que apresentam significância estatística, sendo três indicativas de preferência partidária e a referente à avaliação do governo. As que apresentam maior impacto sobre as chances de voto são as variáveis partidárias, de tal forma que as chances de voto no candidato Fernando Henrique Cardoso aumentam 7,9 vezes quando o eleitor tem preferência pelo PSDB e 3,8 vezes quando tem preferência pelo PFL, em comparação com as chances observadas entre os que não têm preferência pelos grandes partidos. A avaliação positiva do Plano Real faz aumentar três vezes as chances de voto no PSDB, em comparação com a avaliação regular. Quando o eleitor tem preferência pelo PT, as chances de voto representam apenas 6,5\% daquelas observadas quando ele não tem essa preferência. Nessas condições, em 1994, mesmo considerando que a porção de eleitores partidários é inferior à parcela que avalia o governo, o partidarismo foi a variável mais importante dentre as observadas para as chances de intenção de voto no PSDB e a avaliação do Plano Real exerceu menor influência.

Na parte inferior do quadro estão algumas informações importantes. O $\mathrm{R}^{2}$ do modelo de 1994 tem valor razoável $(0,3)$, indicando que esse modelo explica cerca de $30 \%$ da variância da ocorrência de intenção de voto no PSDB. O modelo prevê corretamente $68 \%$ de todos os casos e $88 \%$ das intenções de voto no PSDB, uma proporção elevada. Dos que efetivamente declararam intenção de voto no partido, o modelo prevê corretamente 61\%.

Para 1998, foram construídos três modelos diferentes, porque nenhum dos bancos de dados para aquele ano incluía todas as variáveis propostas para análise. Assim, o primeiro modelo para 1998 não contém a variável referente à ideologia, o segundo não apresenta as variáveis referentes aos candidatos e o terceiro não tem as variáveis indicadoras dos partidos. No primeiro modelo, apresentaram significância estatística oito variáveis: uma demográfica, as quatro indicadoras dos principais partidos, a avaliação do governo e as duas referentes à avaliação dos candidatos. Dentre todas estas 
variáveis, a que tem maior magnitude é a avaliação do governo, de tal forma que eleitores com avaliação positiva têm chance quatro vezes maior de intenção de voto, seguida pela identificação com o PSDB (3,4 vezes), pela opinião sobre a capacidade de resolução do principal problema do candidato (3,3 vezes), pela preferência pelo PFL (2,5 vezes), pela opinião sobre a qualidade para ser presidente (2,3 vezes) e pela identificação com o PMDB (1,4 vezes). As outras duas variáveis significantes implicam diminuição das chances de voto. Entre os eleitores identificados com o PT, a chance é 24\% (ou quatro vezes menor) que a observada entre os não identificados com o partido, e a cada faixa etária a chance é 91\% da observada na faixa anterior, ou seja, quanto mais velho, menor a chance de voto no PSDB.

No segundo modelo de 1998, sem as variáveis referentes aos candidatos, são observadas nove estatisticamente significantes: três demográficas, as quatro indicadoras de partidos, a ideologia e a avaliação do governo. Considerando as magnitudes, os maiores impactos positivos sobre as chances de voto são observados na avaliação do governo, de tal forma que os eleitores que o avaliam positivamente têm chance 8,2 vezes maior de intenção de voto no PSDB, seguida da preferência pelo PSDB (5,4 vezes), pelo PFL (3,2 vezes), pelo PMDB (1,5 vez), pela ideologia (eleitores que avaliam positivamente as privatizações têm chance 1,4 vez maior que os que são neutros) e pelo sexo (chance 1,2 vez maior entre os homens). As demais variáveis exercem impacto negativo sobre as chances de voto. Ser identificado com o PT reduz as chances para 11\% da observada entre os que não se identificam com o partido. A cada faixa etária, a chance é $93 \%$ da observada na faixa anterior. Na região Nordeste do país, a chance é $64 \%$ da observada na região Norte.

No terceiro modelo para 1998, sem as variáveis indicadoras dos partidos, são observadas oito variáveis estatisticamente significantes: quatro demográficas e socioeconômicas, a ideologia, a avaliação do governo e as duas de avaliação dos candidatos. A razão de chance de maior magnitude é a da avaliação de governo - eleitores que o avaliam positivamente têm probabilidade cinco vezes maior de votar no PSDB que os eleitores que fazem avaliação regular —, seguida da avaliação da capacidade do candidato para 
solucionar o principal problema do país (2,6 vezes), da opinião sobre a principal qualidade para ser presidente (1,9 vez) e da ideologia expressa na opinião sobre as privatizações (1,4 vez). Todas as variáveis demográficas e socioeconômicas significantes implicam diminuição das chances de voto. Entre os eleitores que compõem a PEA, a chance é $82 \%$ daquela observada entre os que estão fora da PEA. Nas regiões Nordeste, Sudeste e Sul, as chances são cerca de metade da observada na região Norte.

$\mathrm{Na}$ parte inferior do quadro, vê-se que os $\mathrm{R}^{2}$ desses modelos são próximos de 0,5; isso indica que explicam cerca de $50 \%$ da variância da ocorrência de intenção de voto no PSDB. Os modelos prevêem corretamente cerca de $80 \%$ de todos os casos, e $70 \%$ das intenções de voto no PSDB. Dos que efetivamente declararam intenção de voto no partido, o modelo prevê corretamente em torno de $75 \%$ dos votos.

Para 2002, foram duas modelagens, uma para cada turno da eleição presidencial, ambas com dados do Eseb. No primeiro turno, oito variáveis foram estatisticamente significantes: uma demográfica, duas socioeconômicas, duas indicadoras de partidos, a avaliação do governo e as duas avaliações do candidato. No segundo turno, também foram oito variáveis estatisticamente significantes: uma demográfica, uma socioeconômica, duas indicadoras de partidos, a ideologia, a avaliação do governo e as duas avaliações do candidato.

Os maiores impactos positivos sobre as chances de intenção de voto nos dois turnos decorreram da opinião sobre a principal qualidade para ser presidente. Acreditar que Serra tinha a qualidade de fazer mais pelos mais pobres aumentava as chances de voto no PSDB em 4,4 vezes no primeiro turno e 3,5 vezes no segundo turno, em comparação com não acreditar que ele possuía essa qualidade.

Também exerceram impacto positivo semelhante, nos dois turnos, a identificação com o PSDB (3,7 vezes no primeiro e três vezes no segundo), a opinião sobre a capacidade de resolução do principal problema $(2,4$ vezes no primeiro e três vezes no segundo), a renda familiar (eleitores com renda acima de cinco salários mínimos apresentaram chance de voto 1,7 vez no primeiro turno e 2,2 vezes no segundo turno maior que os com renda abaixo desse patamar) e a avaliação de governo (entre os que avaliavam positivamente, a 
chance foi em torno de 1,6 vez maior nos dois turnos, em comparação com quem fazia avaliação regular). A etnia e a religião exerceram impacto significativo apenas no primeiro turno, de forma que os brancos apresentaram chance 1,4 vez superior aos não brancos e os católicos apresentaram chance 1,8 vez superior aos não católicos. A ideologia foi importante apenas no segundo turno, quando a chance entre os que se posicionavam à direita foi 1,4 vez superior aos que se posicionavam no centro.

O principal impacto negativo sobre as chances de voto no PSDB em 2002 veio da preferência pelo PT. A chance de um eleitor com essa característica votar no PSDB era 10 vezes menor do que a de um eleitor sem essa preferência. Finalmente, no segundo turno, a chance entre os homens representava $75 \%$ da chance observada entre as mulheres.

Os $\mathrm{R}^{2}$ desses modelos são próximos de 0,4, indicando que explicam cerca de $40 \%$ da variância da ocorrência de intenção de voto no PSDB. Os modelos prevêem corretamente mais de $80 \%$ de todos os casos, e cerca de $50 \%$ das intenções de voto no PSDB. Dos que efetivamente declararam intenção de voto no partido, o modelo prevê corretamente em torno de $70 \%$.

Para a eleição de 2006, são apresentados quatro modelos. Os motivos são os mesmos que justificaram as três modelagens para 1998: nenhum dos bancos de dados disponíveis continha todas as variáveis propostas no modelo. O primeiro não tem variável referente à ideologia, o segundo não tem a opinião do eleitor sobre a capacidade de resolução do principal problema, o terceiro não tem a opinião sobre a principal qualidade para ser presidente e o último não tem as variáveis indicadoras de preferência partidária.

No primeiro modelo, apresentaram significância estatística seis variáveis, das quais uma demográfica, duas indicadoras dos principais partidos, a avaliação do governo e as duas referentes à avaliação dos candidatos. A variável com maior magnitude é a preferência pelo PSDB, de tal forma que os eleitores tucanos têm chance 5,7 vezes maior, quando comparados aos sem identificação com os quatro maiores partidos. Em seguida, aparecem as variáveis referentes à avaliação do candidato. Acreditar que Alckmin tinha a qualidade de combater a corrupção fazia aumentar a chance de intenção de voto no PSDB em 4,3 vezes; acreditar que 
ele tinha capacidade para resolver o problema da saúde fazia aumentar a chance em quatro vezes. Entre os eleitores do Sudeste, a chance era 2,4 vezes maior que entre os das regiões Norte e Centro-Oeste. Exerceram impacto negativo sobre as chances de intenção de voto no PSDB a preferência pelo PT, que reduzia para 14\% da observada entre os que não se identificavam com o partido, e a avaliação positiva do governo Lula, que reduzia para 35\% da observada entre os que o avaliavam de forma regular.

No segundo e no terceiro modelo de 2006, foram utilizados splits diferentes do mesmo banco de dados. Um continha perguntas sobre as qualidades dos candidatos; o outro, sobre a capacidade dos candidatos para resolver os problemas do país. Em ambos os modelos, a avaliação do candidato, seja da principal qualidade, seja da capacidade para resolver o principal problema, foi a que apresentou a maior razão de chance, entre 6,4 vezes, entre os eleitores que consideravam Alckmin capaz de resolver a saúde e 7,1 vezes entre os que acreditam que ele tinha a qualidade de combater a corrupção. Nos dois modelos, a preferência pelo PSDB fazia aumentar em mais de seis vezes a chance de voto, mas em ambos os casos a magnitude da razão de chance foi menor que a observada com referência à avaliação do candidato. Outro traço comum aos dois modelos foram as menores chances de voto no PSDB entre os petistas (razão de chance igual a 0,14 no segundo e 0,31 no terceiro modelo) e entre os que avaliavam o governo positivamente $(0,41$ no primeiro e 0,27 no segundo modelo).

As diferenças mais importantes entre os dois modelos referem-se à significância estatística das variáveis indicadoras da região Sudeste e da preferência pelo PMDB no segundo modelo, que incluía a pergunta sobre a qualidade do candidato. Os eleitores de capitais apresentavam chance $50 \%$ inferior e os peemedebistas, 2,6 vezes superior de intenção de voto no PSDB.

No quarto modelo para 2006, sem as variáveis indicadoras dos partidos, são observadas cinco variáveis estatisticamente significantes: duas indicadoras de regiões do país, a avaliação do governo e as duas de avaliação dos candidatos. As razões de chance de maiores magnitudes são as referentes às avaliações do candidato, seja com relação à principal qualidade (sete vezes), seja com relação à capacidade de resolução do 
principal problema (6,7 vezes). Os eleitores do Centro-Oeste e do Sul apresentavam chance duas vezes maior de intenção de votar no PSDB que os eleitores da região Norte.

Entretanto, a variável que exerceu maior impacto sobre as chances de voto no PSDB em 2006 atuou de forma a reduzir as chances de voto no partido. Com efeito, entre os eleitores que avaliavam positivamente o governo Lula, a chance de intenção de voto era cerca de $14 \%$ da observada entre os que faziam avaliação regular do governo.

Os $R^{2}$ dos modelos para 2006 variam entre 0,41 e 0,64, indicando que explicam entre $41 \%$ e $64 \%$ da variância da ocorrência de intenção de voto no PSDB. Os modelos prevêem corretamente mais de $80 \%$ de todos os casos, entre $45 \%$ e $75 \%$ das intenções de voto no PSDB, e dos que efetivamente declararam intenção de voto no partido, o modelo prevê de modo correto entre $67 \%$ e $83 \%$.

De maneira geral, os modelos de regressão logística para a ocorrência de intenção de voto no PSDB indicam a superioridade explicativa e preditiva da preferência partidária pelo PSDB e pelo PT, da avaliação do governo e das avaliações do candidato. Observando-se os dados de forma longitudinal, é possível destacar que o partidarismo perde força ao longo do tempo, tendo em vista especialmente o fato de que a preferência pelo PT deixa de ser significante ao nível de $1 \%$ e mantém significância apenas ao nível de 5\% nos dois últimos modelos com a variável, e o aumento dos erros-padrão referentes às variáveis indicadoras da preferência pelo PSDB e pelo PT. Dessa forma, as variáveis que mais exerceram impacto na intenção de voto no PSDB durante todo o período analisado foram as avaliações dos governos e dos candidatos. 
4.2. Modelos gerais de regressão logística multivariados para o PT

Quadro 40: Modelos gerais de regressão logística para a ocorrência de voto no PT

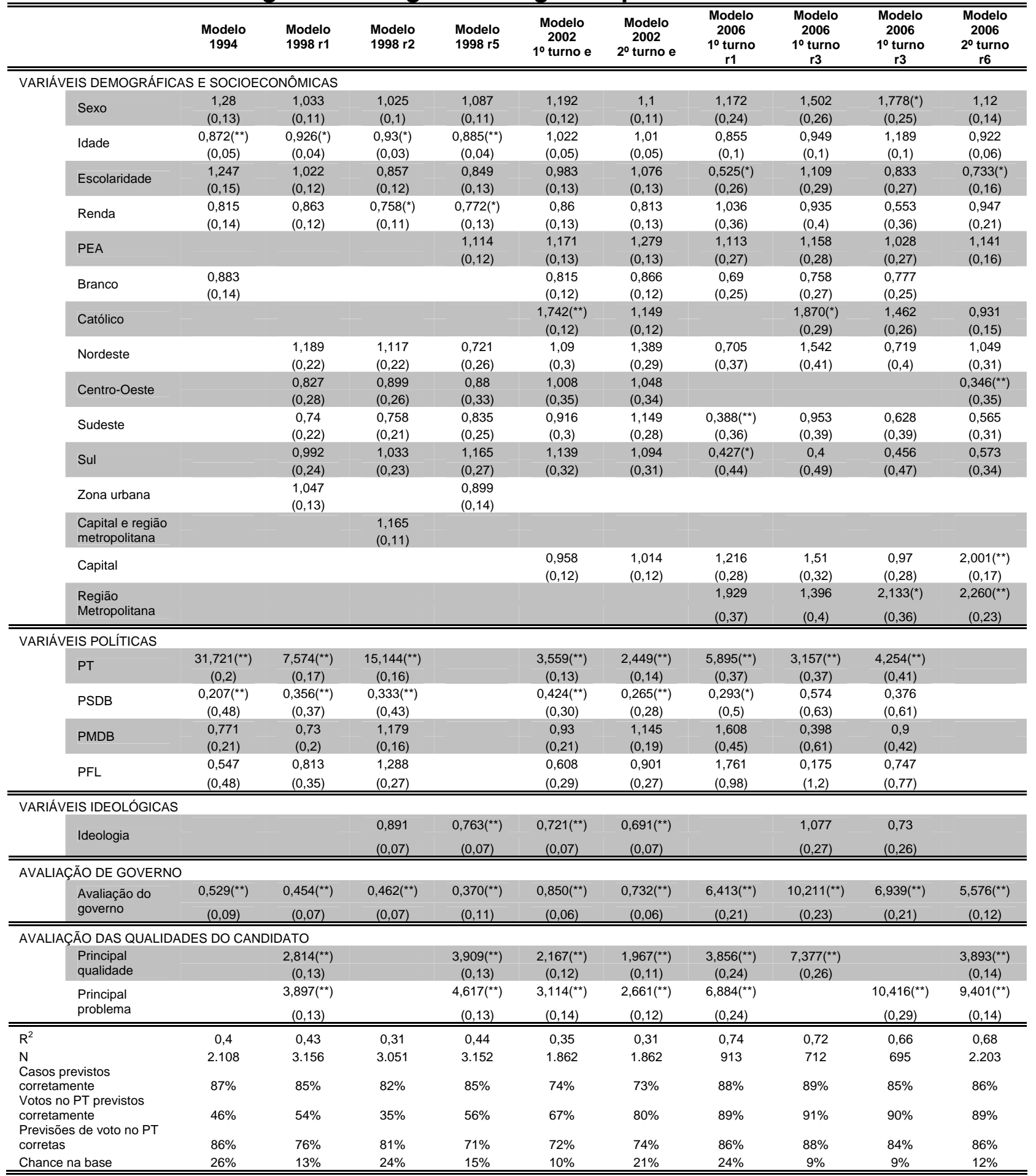

Notas: $\left({ }^{*}\right) p<0,05 .\left({ }^{*}\right) p<0,01$.

Fonte: 1994: Datafolha (1994); 1998: Vox Populi (1998); 2002: Almeida et al. (2002) e Ipsos

Opinion (2002); 2006: Analítica Consultoria (2006). 
O modelo para a eleição de 1994 apresenta quatro variáveis com significância estatística: uma demográfica, duas indicadoras de preferência partidária e a referente à avaliação do governo. A que apresenta maior impacto positivo sobre as chances de voto é a preferência pelo PT. De fato, a magnitude da razão de chance da intenção do voto entre não petistas e petistas é a maior observada nesta pesquisa. Um eleitor do PT tinha chance 31,7 vezes maior de votar no partido que um não petista. As demais variáveis significantes do modelo atuaram no sentido de reduzir as chances de voto no PT. Assim, a probabilidade de um eleitor mais velho votar no partido é menor; a cada faixa etária a chance é $87 \%$ da observada na faixa anterior; entre os que avaliam positivamente o Plano Real, a chance de intenção de voto é 53\% da observada entre os que fizeram avaliação regular; e entre os eleitores com preferência pelo PSDB a probabilidade de voto no PT é cerca de $21 \%$ daquela obtida entre os que não tinham essa preferência. Ou seja: em 1994, das variáveis observadas, o partidarismo foi a mais importante para as chances de intenção de voto no PT.

Assim como nos modelos para o PSDB, a parte inferior do quadro apresenta informações importantes sobre a qualidade dos modelos. $\mathrm{O} \mathrm{R}^{2}$ do modelo de 1994 atinge 0,4, indicando que esse modelo explica cerca de 40\% da variância da ocorrência de intenção de voto no PT. O modelo prevê corretamente $87 \%$ de todos os casos e $46 \%$ das intenções de voto no PT. Dos que efetivamente declararam intenção de voto no partido, o modelo prevê de modo correto 86\%, um índice elevado.

O primeiro modelo para 1998 apresenta seis variáveis com significância estatística: uma demográfica, duas indicadoras dos principais partidos, a avaliação do governo e as duas referentes à avaliação dos candidatos. De todas essas variáveis, a com maior magnitude é a preferência pelo PT: os petistas tinham chance 7,6 vezes superior de intenção de voto no partido, quando comparados aos que não tinham essa preferência. Em seguida, a avaliação sobre a capacidade de resolução do principal problema aumentava a probabilidade em 3,9 vezes e a avaliação sobre a existência da principal qualidade para ser presidente fazia a chance de voto aumentar 2,8 vezes. As outras três variáveis significantes implicam diminuição das chances 
de voto. Entre os eleitores identificados com o PSDB, a chance é $36 \%$ da observada entre os não identificados com o partido; entre os que avaliavam positivamente o governo Fernando Henrique Cardoso a chance de voto no PT era $45 \%$ da observada entre os que o avaliavam de forma regular; a cada faixa etária, a chance é $93 \%$ da observada na faixa anterior, ou seja, quanto mais velho, menor a chance de voto no PT.

No segundo modelo de 1998, sem as variáveis referentes aos candidatos, são observadas cinco variáveis estatisticamente significantes: uma demográfica, uma socioeconômica, duas indicadoras de partido e a avaliação do governo. Considerando-se as magnitudes, o único impacto positivo sobre as chances de voto no PT é observado entre os que tinham preferência pela legenda. Assim, um eleitor petista tinha chance 15,1 vezes superior de votar no partido, quando comparado a um eleitor sem essa preferência. Todas as outras variáveis exerceram efeitos negativos, de tal forma que a identificação com o PSDB diminuía as chances para $33 \%$ da obtida entre os eleitores sem essa preferência, a avaliação positiva do governo derrubava a probabilidade de intenção de voto no PT (que caía para $46 \%$ da observada entre os que faziam avaliação regular), eleitores com renda familiar acima de cinco salários mínimos tinham probabilidade de intenção de voto que era $76 \%$ da obtida entre os eleitores com renda familiar abaixo desse patamar e, a cada faixa etária, a chance era equivalente a 93\% da observada na faixa anterior.

No terceiro modelo para 1998, sem as variáveis indicadoras dos partidos, são observadas seis variáveis estatisticamente significantes, sendo uma demográfica, uma socioeconômica, a ideologia, a avaliação do governo e as duas de avaliação dos candidatos. A razão de chance de maior magnitude refere-se à avaliação da capacidade de resolução do principal problema do país. Entre os eleitores que acreditam que Lula era capaz de resolver o problema da saúde a chance de voto no PT era 4,6 vezes superior, quando comparada aos que não tinham essa opinião. O impacto dessa variável foi seguido da opinião sobre a principal qualidade para ser presidente: acreditar que Lula tinha essa qualidade aumentava as chances de voto em 3,9 vezes. As outras variáveis significantes exerceram efeitos negativos, 
principalmente a avaliação do governo - a probabilidade de voto no PT entre os que o avaliavam positivamente era 37\% da obtida entre os que faziam avaliação regular. Entre os favoráveis ao processo de privatização, a chance de voto era $76 \%$ da encontrada entre os que eram neutros com relação a esse processo; eleitores com renda familiar acima de cinco salários mínimos tinham probabilidade de intenção de voto que era $77 \%$ da obtida entre os eleitores com renda familiar abaixo desse patamar; a cada faixa etária, a chance era equivalente a $89 \%$ da observada na faixa anterior.

Os $\mathrm{R}^{2}$ desses modelos variaram entre 0,31 e 0,44, indicando que explicam entre 31\% e 44\% da variância da ocorrência de intenção de voto no PT. Os modelos prevêem corretamente mais de $82 \%$ de todos os casos, entre 35\% e 56\% das intenções de voto no PT, e, dos que efetivamente declararam intenção de voto no partido, o modelo prevê corretamente acima de $70 \%$. Os modelos com melhores ajustes foram o primeiro e o terceiro, ambos contendo as variáveis de avaliação dos candidatos.

Para 2002, foram criados dois modelos com dados do Eseb, um para cada turno da eleição presidencial. No primeiro turno, foram consideradas sete variáveis estatisticamente significantes, das quais uma socioeconômica, duas indicadoras de partidos, ideologia, avaliação do governo e as duas avaliações do candidato. No segundo, seis variáveis estatisticamente significantes: duas indicadoras de partidos, a ideologia, avaliação do governo e as duas avaliações do candidato.

Os maiores impactos positivos sobre as chances de intenção de voto nos dois turnos são exercidos pela preferência pelo PT, que fazia a probabilidade de voto no partido aumentar 3,6 vezes no primeiro turno e 2,4 vezes no segundo turno. Seguia-se a opinião sobre a capacidade de Lula para resolver o principal problema do país e a opinião sobre a principal qualidade para ser presidente: acreditar que Lula resolveria o desemprego fazia aumentar a chance de voto em 3,1 vezes no primeiro turno e 2,7 vezes no segundo turno, e acreditar que ele tinha a qualidade de fazer mais pelos mais pobres elevava a probabilidade em 2,2 vezes no primeiro turno e 2 vezes no segundo turno, sempre em comparação com os eleitores que não acreditam que Lula tinha essa capacidade e essa qualidade. A religião 
exerceu impacto positivo apenas no primeiro turno, quando os católicos apresentaram chance 1,8 vez superior aos não católicos de votar no PT.

As outras variáveis exerceram impacto negativo, especialmente a preferência pelo PSDB. No primeiro turno a chance de um peessedebista votar no PT era equivalente a $42 \%$ da chance de um não peessedebista; no segundo turno, o índice foi de $27 \%$, ou seja, foi ainda mais improvável que um eleitor como preferência pelo PSDB votasse no PT. Além desta variável, verifica-se que eleitores posicionados ideologicamente à direita apresentaram probabilidade que era cerca de $70 \%$ da obtida entre os que se posicionavam ao centro, e entre os que avaliavam positivamente o governo, a chance de voto no PT era entre $85 \%$, no primeiro turno, e 73\%, no segundo turno, menor que entre os que faziam avaliação regular.

Nestes modelos, os $\mathrm{R}^{2}$ estão entre 0,31 e 0,35, indicando que explicam cerca de um terço da variância da ocorrência de intenção de voto no PT. Os modelos prevêem corretamente cerca de $74 \%$ de todos os casos, entre $67 \%$ e $80 \%$ das intenções de voto no PT, e, dos que efetivamente declararam intenção de voto no partido, o modelo prevê acertadamente acima de 70\%.

Para a eleição de 2006, são apresentados quatro modelos. Os motivos já foram apresentados ao analisarmos os modelos para a ocorrência de intenção de voto no PSDB. O primeiro não tem variável referente à ideologia, o segundo não tem a opinião do eleitor sobre a capacidade de resolução do principal problema, o terceiro não tem a opinião sobre a principal qualidade para ser presidente e o último não tem as variáveis indicadoras de preferência partidária.

No primeiro modelo, apresentaram significância estatística oito variáveis, das quais duas demográficas, uma socioeconômica, duas indicadoras dos principais partidos, a avaliação do governo e as duas referentes à avaliação dos candidatos. De todas, aquela com maior magnitude foi a opinião do eleitor sobre a capacidade de Lula para resolver o principal problema do país: os que acreditavam nessa capacidade apresentavam chance 6,9 vezes superior do que aqueles que não acreditavam. A seguir, apareceram a avaliação do governo (que tornava a intenção de voto no PT 6,4 vezes mais provável entre os que faziam uma 
avaliação positiva, quando comparados aos que avaliavam de forma regular), a preferência pelo PT (que aumentava a probabilidade em 5,9 vezes, em comparação com os eleitores que não tinham preferência pelo partido) e a opinião sobre a posse por parte de Lula da principal qualidade para ser presidente (quem acreditava apresentava chance 3,9 vezes superior a quem não acreditava).

Exerceu impacto negativo a preferência pelo PSDB, que reduzia as chances de intenção de voto no PT para $29 \%$ da observada entre os que não se identificavam com aquele partido. Além dessa variável partidária, as chances de Lula eram significativamente menores no Sudeste (razão de chance igual a 0,39$)$ e no Sul $(0,43)$, quando os eleitores destas regiões eram comparados com os do Norte e do Centro-Oeste, e entre os eleitores com escolaridade acima do ensino fundamental completo $(0,53)$, quando comparados aos eleitores que haviam alcançado até esse nível escolar.

No segundo e no terceiro modelo de 2006, como já dissemos, foram utilizados splits diferentes do mesmo banco de dados, um com variáveis relacionadas às qualidades dos candidatos, o outro com variáveis sobre a capacidade dos candidatos para resolver os problemas do país. No modelo relativo a qualidades, foram quatro variáveis significantes, sendo uma socioeconômica, uma indicadora de partido, a avaliação do governo e a avaliação do candidato. A variável com maior razão de chance foi a avaliação do governo, de tal forma que os eleitores que o avaliavam positivamente tinham probabilidade 10,2 vezes maior de intenção de voto no PT do que aqueles que o avaliavam de forma regular. Depois, vinha a variável referente à opinião do eleitor sobre Lula ter a qualidade de combater a corrupção. Entre os que acreditam nisso, a probabilidade de voto no PT foi 7,4 vezes maior que a observada entre os que não acreditavam. A preferência pelo PT tornava 3,2 vezes mais provável o voto no partido, e entre os católicos a chance era 1,9 vez maior.

No modelo com a capacidade para resolver o problema da saúde, foram cinco variáveis significantes: duas demográficas, uma indicadora de partido, a avaliação do governo e a avaliação do candidato. Esta última foi a que apresentou razão de chance com maior magnitude. Entre os eleitores 
que julgavam Lula capaz de resolver os problemas da saúde, a probabilidade de voto no PT foi 10,4 vezes maior do que entre os que não julgavam dessa forma. Na seqüência, a avaliação positiva do governo tornava a chance de intenção de voto em seu candidato 6,9 vezes mais provável, e a preferência pelo PT elevava a chance em 4,3 vezes. Entre os homens, a chance era 1,8 vez maior do que entre as mulheres, e nas regiões metropolitanas a probabilidade de intenção de voto no PT era o dobro da observada fora dessas áreas. Nesses dois modelos, baseados no mesmo banco de dados, nenhuma variável exerceu impacto negativo estatisticamente significante sobre o voto no PT, nem mesmo a preferência pelos outros partidos.

No quarto modelo para 2006, sem as variáveis indicadoras dos partidos, foram observadas sete variáveis estatisticamente significantes: três demográficas, uma socioeconômica e as avaliações do governo e do candidato. A razão de chance de maior magnitude foi a referente à avaliação do candidato com relação à capacidade de resolver o principal problema acreditar que Lula resolveria os problemas da saúde elevava a probabilidade de voto no PT em 9,4 vezes — , seguida da avaliação positiva do governo (5,6 vezes) e da opinião de que Lula tinha a qualidade de combater a corrupção (3,9 vezes). Também tiveram impacto positivo sobre as chances de voto no partido a residência em capitais (duas vezes) e a residência em regiões metropolitanas (2,3 vezes). Entre os eleitores de maior escolaridade, a probabilidade de votar no PT era $73 \%$ da observada entre os de menor escolaridade, e no Centro-Oeste a chance foi 35\% daquela obtida entre os eleitores da região Norte.

Os $\mathrm{R}^{2}$ dos modelos para 2006 variam entre 0,66 e 0,76, indicando que explicam mais de dois terços da variância da ocorrência de intenção de voto no PT. Os modelos prevêem corretamente mais de $85 \%$ de todos os casos, cerca de $90 \%$ das intenções de voto no PT, e, dos que efetivamente declararam intenção de voto no partido, o modelo prevê corretamente cerca de 85\%.

De maneira geral, os modelos de regressão logística para a ocorrência de intenção de voto no PT apontam para a superioridade explicativa e preditiva da preferência partidária pelo PT e PSDB, da avaliação do governo e das avaliações do candidato. Observando-se os dados ao longo do tempo, 
é possível destacar que o partidarismo perde força, especialmente porque a preferência pelo PSDB deixa de ser significante ao nível de 1\% no primeiro modelo para 2006 e perde significância nos dois últimos modelos com a variável. Também se nota uma queda na importância da preferência pelo PT nos cálculos das probabilidades de intenção de voto no partido, que, quando se torna governo, passa a ter suas chances mais influenciadas pela avaliação do governo e pelas avaliações do candidato.

\subsection{Considerações finais}

Comparando os modelos de PSDB e de PT, é possível distinguir que o voto em reeleições é mais previsível que em outras ocasiões. Também se verifica que, em reeleições, as características socioeconômicas e a avaliação do governo são mais importantes e que, em eleições nas quais nenhum candidato busca a recondução ao posto, a avaliação do governo tem peso menor.

No geral, os modelos permitem que se conclua pela aceitação da hipótese de que as variáveis de curto prazo exercem maior efeito sobre o comportamento eleitoral. Em todos os modelos analisados, estas variáveis foram estatisticamente significantes ao nível de $1 \%$. 


\section{Conclusões}

Desde 1989, ocorrem no Brasil eleições presidenciais com sufrágio universal, nas quais todos os cidadãos acima de 16 anos podem participar da escolha do primeiro mandatário do país. Desde então, foram realizadas cinco eleições, das quais quatro marcadas pela disputa entre o Partido da Social Democracia Brasileira (PSDB) e o Partido dos Trabalhadores (PT). Este trabalho procurou analisar essa disputa sob o ponto de vista do eleitor, para encontrar os aspectos mais importantes que explicam a ocorrência desse embate.

Ainda que durante esse período os estudos a respeito da decisão do voto nas eleições presidenciais no Brasil tenham crescido em quantidade e qualidade, as questões ligadas à disputa entre os dois partidos raramente foram abordadas pelos cientistas políticos. Boa parte desses estudos tratou de eleições isoladas ou da compreensão de algum aspecto pontual das disputas, com ênfase nas condições socioeconômicas, na ideologia e na avaliação do governo. Entretanto, a disputa entre o PSDB e o PT pela Presidência da República permaneceu quase ignorada, apesar de ser um traço distintivo e, até mesmo, inesperado, dadas as nossas características institucionais.

No exame aqui desenvolvido, consideramos um amplo conjunto de variáveis, reunidas sob as três principais abordagens teóricas sugeridas pela literatura internacional e nacional sobre o tema. Procuramos compreender melhor o papel desempenhado pelas características demográficas e socioeconômicas na decisão do voto, bem como testar as hipóteses mais importantes derivadas da teoria sociológica que tem como expoentes os trabalhos dos pesquisadores da Universidade de Colúmbia e, no Brasil, a tese de Castro sobre a centralidade da sofisticação política. Também foram investigados os impactos exercidos pelas características políticas e ideológicas dos eleitores sobre o comportamento eleitoral e testadas as hipóteses mais destacadas, inspiradas pela escola psico-sociológica que tem como principais representantes os pesquisadores da Universidade de Michigan e, no Brasil, a tese de Singer sobre a ideologia na decisão do voto. Por fim, foram considerados os efeitos das avaliações de governo e dos candidatos sobre a 
decisão eleitoral e foram testadas as hipóteses derivadas da teoria da escolha racional, que tem como trabalho seminal o livro de Downs e, no Brasil, a tese de Carreirão sobre o voto econômico.

Nesse contexto, a intenção principal deste trabalho foi procurar demonstrar que os efeitos de longo prazo sobre a decisão de voto, privilegiado pelas duas primeiras abordagens, são importantes, mas os de curto prazo, defendidos pela terceira abordagem, têm maior impacto sobre as chances de o eleitor votar em um ou outro partido.

Os testes de hipóteses foram realizados com apoio em bancos de dados resultantes de pesquisas de opinião pública por amostragem representativa do conjunto dos eleitores brasileiros. Nesse ponto residiu a primeira dificuldade para a realização desta pesquisa. Os pesquisadores dos EUA contam com ampla base empírica para realizar seus estudos. Desde a década de 40, centros de pesquisa baseados nas universidades - como o National Opinion Research Center, da Universidade de Chicago, e o National Election Studies, da Universidade de Michigan - produzem diversas pesquisas de cunho acadêmico que proporcionam bases de dados quantitativas para numerosas investigações importantes em diversas áreas, notadamente na de comportamento eleitoral.

No Brasil, o processo de produção de pesquisas acadêmicas de opinião pública ainda é muito tímido. Os estudos disponíveis são poucos, limitados e sem continuidade. Para contornar essa dificuldade, optamos por utilizar bancos de dados produzidos por institutos de pesquisa privados. As pesquisas realizadas por esses institutos foram realizadas para divulgação na imprensa ou para a orientação de campanhas eleitorais e, em geral, não contemplam aspectos centrais para a compreensão dos processos eleitorais, tais como as concebidas pelos projetos acadêmicos. Dentre esses aspectos, devem ser destacados as diferentes formas de seleção da amostra, a utilização de questionários de diferentes formatos e a falta de padronização nas formulações de perguntas sobre um mesmo conceito. Essas dificuldades foram contornadas com a utilização de 25 diferentes bases de dados produzidas por cinco diferentes instituições. 
As hipóteses foram testadas estatisticamente por meio de análises de regressões logísticas multivariadas, nas quais buscávamos identificar quais foram os aspectos mais determinantes na decisão de voto no PSDB e no PT. Esse tipo de modelagem de dados é adequado para descrever a chance ou a probabilidade de sucesso de algum fenômeno a partir de uma ampla gama de variáveis explicativas. Isso nos permitiu testar as hipóteses sociológicas, sócio-psicológicas e racionais da decisão do voto, assim como a hipótese da superioridade explicativa e preditiva dos aspectos de curto prazo.

Este trabalho se inseriu no âmbito dos estudos sobre o comportamento eleitoral nas eleições presidenciais brasileiras. Os trabalhos mais importantes sobre esse tema, as teses de Castro (1994), Singer (2000) e Carreirão (2002), , abriram o caminho para a compreensão dessa temática e procuraram apontar os aspectos que consideram mais importantes.

Em meio a outras afirmações pertinentes, o principal argumento de Castro é que, para compreender o comportamento eleitoral, é necessário dar conta de uma rede complexa de condicionantes que considera o contexto estrutural demográfico, socioeconômico e político-institucional em que vivem os eleitores. A autora sustenta que as condições socioeconômicas do eleitorado são determinantes do seu comportamento político, especialmente porque condicionam o grau de sofisticação política de cada cidadão. Entre essas condições, ela destaca a escolaridade, a renda, a idade, o gênero e a etnia. Dessa forma, entre eleitores mais escolarizados, de maior renda, mais jovens, homens e brancos deveria ser encontrada a maior proporção de cidadãos sofisticados. Além disso, ela defende que a sofisticação política está relacionada à preferência partidária e à participação em associações. Levando em conta uma série de aspectos, afirma que a sofisticação política pode ser considerada o fator mais próximo do comportamento eleitoral para a grande maioria do eleitorado.

Singer detém-se especialmente sobre a questão da ideologia na decisão do voto. Seu principal argumento é que a identificação ideológica é um dos principais determinantes do voto. Para avaliar a força da associação entre identificação ideológica e voto, este autor buscou comparar o grau de associação encontrado com o de outras variáveis de curto e de longo prazo. 
Como hipóteses de curto prazo, testou o voto de protesto, a avaliação dos governos, dos políticos e do Plano Real e a simpatia por uma política de redução da intervenção estatal; como hipóteses de longo prazo, a renda, a escolaridade e a identificação partidária.

Os testes de todas essas hipóteses revelaram, por um lado, que a identificação partidária foi um instrumento de predição do voto excelente, mas de alcance restrito à minoria dos eleitores que se identificavam com algum partido; por outro lado, que a identificação ideológica também foi uma excelente preditora do voto, mas com uma abrangência maior que a preferência partidária e, portanto, mais generalizável. Além disso, Singer mostrou que a ideologia era estável ao longo do tempo e que existiam conteúdos políticos referentes a cada posicionamento, concluindo pela superioridade explicativa da ideologia.

A tese de Carreirão propõe que um modelo explicativo do voto nas eleições presidenciais brasileiras deve incluir pelo menos quatro variáveis, quais sejam, as imagens de candidatos e partidos - em termos de esquerda e direita ou relacionadas aos interesses sociais que defendem —, a avaliação do governo, a avaliação das características pessoais dos candidatos e o grau de escolaridade.

Em sua análise, a escolaridade é vista como uma proxy de sofisticação política da qual depende diretamente o comportamento. Eleitores mais escolarizados teriam comportamento distinto dos eleitores menos escolarizados. Os primeiros tenderiam ao voto econômico e ao ideológico; os outros, a votar nos candidatos que se apresentam como defensores dos interesses do povo. Independentemente do nível de escolaridade, muitos eleitores recorrem, para a decisão do voto, a uma avaliação das qualidades pessoais dos candidatos, como competência administrativa, honestidade e credibilidade.

Nosso trabalho procurou seguir o caminho aberto por esses três estudos - agora, sob uma perspectiva temporal, metodológica e analítica mais ampla. Para tanto, aliaram-se mais informações, mais dados de pesquisas quantitativas e nova abordagem dos argumentos e resultados preexistentes, a fim de se obter uma visão mais completa sobre a disputa presidencial brasileira, que não ficasse restrita a um horizonte temporal 
limitado e a uma ou outra questão envolvente de reduzido número de fatores. A análise baseou-se em dados ao nível individual, assim como naqueles três estudos, mas tentou avançar, ao considerar maior número de eleições e incluir simultaneamente todas as variáveis julgadas relevantes. Isso possibilitou testar o poder explicativo relativo destas variáveis e definir quais os fatores relevantes para explicar o comportamento dos eleitores brasileiros ao longo do tempo.

A análise que fizemos aqui mostra que, no caso da disputa entre 0 PSDB e o PT nas eleições presidenciais brasileiras, conhecer as características demográficas e socioeconômicas dos eleitores revela muito pouco sobre sua decisão de votar em um ou em outro candidato desses partidos à Presidência. Os modelos logísticos para a intenção de voto no PSDB e no PT, tendo como covariáveis essas características, explicam muito pouco o comportamento eleitoral e não são bons preditores do voto.

As características apontadas por Castro como importantes para o comportamento do eleitor - o sexo, a escolaridade, a renda e a etnia — não se encontram claramente relacionadas com a direção do voto, uma vez que não é possível distinguir um padrão de comportamento eleitoral entre os grupos demográficos e socioeconômicos. No que diz respeito à escolaridade, o aspecto mais importante a ser destacado é que os eleitores menos escolarizados tendem a apoiar o partido do governo, enquanto que os mais escolarizados tendem a apoiar a oposição. Ainda assim, essa diferença foi estatisticamente significante em apenas quatro dos 12 modelos demográficos e socioeconômicos, o que nos impede qualquer afirmação conclusiva, e apenas permite indicar que esse parece ser o padrão.

As características socioeconômicas mais importantes para distinguir os eleitores dos dois partidos no decorrer de todo o período foram a renda familiar, a cor da pele e a região do país. Todavia, quando levamos em consideração tais características, as diferenças observadas entre os partidos são muito pequenas e não parecem determinantes de qualquer resultado eleitoral. Não obstante, os resultados das eleições de 2006 foram os que mais sofreram influências das características demográficas e socioeconômicas quando analisadas separadamente e que mais polarizaram os eleitorados dos dois 
partidos, mas a aparente polarização não resistiu aos testes posteriores. Por essa razão, descartamos a superioridade de uma hipótese sociológica para a decisão do voto entre PSDB e PT.

O segundo conjunto de variáveis de longo prazo que tratamos de examinar foram as partidárias e ideológicas. Nossa principal hipótese com relação ao efeito do partidarismo na decisão do voto baseou-se na expectativa de encontrar crescente relevância do partidarismo no disputa entre PSDB e PT, especialmente por conta da continuidade da disputa. A análise empreendida revelou que conhecer a identificação partidária é importante para explicar e prever o voto; contudo, essa identificação, além de se restringir a parcela minoritária do eleitorado, parece perder força explicativa e preditiva ao longo do tempo, contrariando as expectativas.

Os dados apresentados e analisados sugerem o enfraquecimento do voto baseado na identificação partidária. Para o PSDB, o partidarismo nunca foi aspecto importante e em nenhuma eleição os modelos indicam mais de 20\% de explicação da variância observada. De qualquer forma, é possível perceber uma tendência de alinhamento dos eleitores peessedebistas, peemedebistas e pefelistas em torno das candidaturas tucanas, contra as candidaturas petistas. Mesmo assim, verifica-se que o apoio desses partidos ao PSDB não acrescenta muito aos modelos, perde vigor ao longo do tempo e, principalmente, parece perder ainda mais força nas decisões em segundo turno, justamente quando deveriam ser mais importantes.

Se para o PSDB essa variável nunca foi muito importante, para o PT deixa de sê-lo durante o período em que ambos protagonizaram a disputa. De fato, o poder explicativo e preditivo dos modelos para o PT parece diminuir ao longo do tempo; isto sugere que, para vencer uma eleição presidencial, é preciso ir além das bases partidárias. Assim, o PT conseguiu vencer as eleições de 2002 e 2006 graças ao apoio que obteve fora dos limites do círculo daqueles que se identificam com o partido, De qualquer maneira, independentemente da aparente erosão das bases partidárias, é preciso destacar que a identificação com o PT é a principal variável explicativa de longo prazo na disputa presidencial brasileira - tanto porque reúne a maior quantidade de eleitores, em torno de 15\% em média durante 
todo o período, como pela grande aderência que essa identificação tem com o voto. Também cabe destacar que a identificação com PMDB e PFL não influi em nada nos modelos de comportamento eleitoral para o PT.

Neste trabalho, assim como Singer, acreditamos ter conseguido mostrar que a ideologia tem relação com o voto. Contudo, nossa análise mostrou que tal relação é muito tênue e não consegue dar conta adequadamente do comportamento eleitoral, no que diz respeito ao voto no PSDB ou no PT. Como o partidarismo, a ideologia parece ser importante, mas tem âmbito ainda mais restrito. Sem dúvida, as posições ideológicas conduzem a comportamentos eleitorais diversos, mas essa diversidade está distante de determinar o resultado eleitoral. Para efeitos da análise que aqui realizamos, a ideologia parece ser menos importante que o partidarismo. De qualquer forma, endossamos a conclusão de Singer sobre a necessidade da inclusão de alguma medida da ideologia, especialmente 0 autoposicionamento, nas pesquisas sobre o comportamento eleitoral e sobre intenção de voto.

Ao final do segundo capítulo, integramos os dois conjuntos de variáveis com efeito de longo prazo em um mesmo modelo, procurando testar as hipóteses relacionadas a algum tipo de "qualidade" de eleitor. Observando simultaneamente as características demográficas, socioeconômicas, políticas e ideológicas, concluímos que a capacidade explicativa dos modelos eleva-se para índices entre $20 \%$ e $30 \%$ da variância do voto nos dois partidos, exceto o modelo para o PT em 1994, que atinge 38\% de explicação. Consideramos essa capacidade muito baixa, especialmente tendo em conta que foram utilizadas 12 variáveis independentes. Dessa forma, descartamos a superioridade de um modelo de voto que considere apenas variáveis de longo prazo e podemos afirmar, com segurança, que não existem bases demográficas, socioeconômicas, partidárias e ideológicas sólidas de apoio aos partidos nas eleições presidenciais.

No último capítulo da tese, procuramos avançar no caminho aberto pela tese de Carreirão, testando o impacto das avaliações de governo e dos candidatos sobre o comportamento eleitoral. A partir dos pressupostos da racionalidade presentes na obra de Downs e desenvolvidos por Popkin, 
tratamos de observar aspectos mais relacionados à vida cotidiana dos eleitores, em busca dos fatores relevantes para a disputa. Dessa forma, procuramos investigar a avaliação do governo e a avaliação dos candidatos, particularmente porque estes aspectos parecem constituir a melhor informação de que dispõe o eleitor no mundo incerto da política brasileira e podem ser utilizados por qualquer um, seja qual for sua condição demográfica, socioeconômica, política e ideológica.

A avaliação dos candidatos foi operacionalizada a partir das opiniões dos eleitores sobre as principais qualidades que um candidato deveria ter para ser presidente e sobre os principais problemas do país. Uma vez que os eleitores são pouco sofisticados e informados sobre os processos político, partidário e eleitoral, o que se esperava é que sua opinião sobre a existência, nos candidatos presidenciais, da principal qualidade e da capacidade de resolver o principal problema deveria ser o aspecto mais importante da decisão do voto.

A análise das regressões logísticas com as avaliações, tanto de governo, quanto de candidatos, mostrou que essas variáveis são as que melhor explicam e prevêem o comportamento eleitoral do brasileiro. De todos os modelos analisados para o PSDB e para o PT os referentes aos aspectos de curto prazo da decisão de voto foram os melhores, obtendo maiores $\mathrm{R}^{2} \mathrm{e}$ mais altos índices de acerto em suas previsões. Ainda assim, para ter uma visão mais realista e parcimoniosa das eleições presidenciais, construímos um modelo com todas as variáveis simultaneamente, para buscar aferir quais são as mais determinantes para o comportamento eleitoral.

De maneira geral, os modelos de regressão logística para a ocorrência de intenção de voto no PSDB e no PT apontam para a superioridade explicativa e preditiva da preferência partidária pelo PSDB e PT, da avaliação do governo e das avaliações do candidato. Observando os dados para o PSDB de forma longitudinal, é possível reforçar que o partidarismo perde força ao longo do tempo, tendo em vista especialmente que a preferência pelo PT deixa de ser significante ao nível de 1\% e mantém significância apenas ao nível de $5 \%$ nos dois últimos modelos com a variável. Assim, as variáveis que mais exerceram impacto na intenção de voto no PSDB, durante 
todo o período analisado, foram as avaliações dos governos e dos candidatos. A avaliação do governo foi mais forte quando o partido buscava a reeleição e mais fraca nos demais pleitos, enquanto a avaliação dos candidatos parece ganhar força na medida em que as eleições se sucedem.

Observando os dados dos modelos do PT ao longo do tempo, é possível destacar que o partidarismo perde força, mormente porque a preferência pelo PSDB deixa de ser significante ao nível de 1\% no primeiro modelo para 2006 e perde significância nos dois últimos modelos com a variável. Também se observa queda na importância da preferência pelo PT nos cálculos das probabilidades de intenção de voto no partido, que, quando de torna governo, passa a ter suas chances mais influenciadas pela avaliação do governo e pelas avaliações do candidato. A avaliação do governo torna-se central para os modelos do partido apenas em 2006, quando disputa a reeleição. Deve-se destacar ainda que, ao longo do tempo, as avaliações do candidato superam a identificação partidária nos modelos.

Ao comparar os modelos de PSDB e de PT, pode-se distinguir que o voto em reeleições é mais previsível que em outras ocasiões. Também se verifica que, em reeleições, as características socioeconômicas e a avaliação do governo são mais importantes e que, nas eleições em que nenhum candidato busca a recondução ao posto, a avaliação do governo tem menor peso.

No geral, os modelos permitem que se conclua pela aceitação da hipótese de que as variáveis de curto prazo exercem maiores efeitos sobre o comportamento eleitoral. Em todos os modelos analisados, tais variáveis foram estatisticamente significantes ao nível de 1\%.

Ao final da pesquisa, a conclusão que parece mais importante a respeito da disputa entre PSDB e PT é que talvez seja mais conjuntural do que estrutural. Com efeito, nada indica uma cristalização nessa disputa que permita afirmar, com segurança, que apenas esses dois partidos devem dominar a disputa presidencial brasileira, tal como acontece nos EUA entre democratas e republicanos. A explicação mais plausível para a continuidade da luta política brasileira não deve ser buscada nos partidos, mas nas janelas de oportunidades abertas aos candidatos. Em um contexto eleitoral com maior fragmentação e com predomínio de avaliações regulares ou negativas 
do governo, podem ser abertas portas para a vitória de um candidato formalmente desvinculado dos grandes partidos, desde que ele convença a população de que tem as qualidades e as capacidades necessárias para se tornar presidente.

Assim, esta pesquisa procurou analisar, de maneira abrangente e com sólida base empírica, as principais questões relacionadas à disputa presidencial no Brasil, organizando de maneira sistemática as teorias, hipótese, informações e dados disponíveis ao pesquisador. Todas as campanhas eleitorais tiveram suas particularidades e desdobramentos específicos, que não podem ser negligenciados. No entanto, sua principal característica é a de serem mais influenciadas, não pela estrutura e por aspectos de longo prazo, mas pela conjuntura e pelas questões de curto prazo. 


\section{REFERÊNCIAS}

ALMEIDA, Alberto Carlos. (2006). Por que Lula? O contexto e as estratégias políticas que explicam a eleição e a crise. Record: Rio de Janeiro.

ALMEIDA, Alberto Carlos \& YOUNG, Clifford. (2002). As bases ideológicas do comportamento eleitoral. Mimeo. 18 p.

ALMEIDA, Jorge. (1998). Como vota o brasileiro: perfil ideológico do eleitor e evolução do voto nas pesquisas de opinião de 1994. São Paulo: Xamã.

AMORIM NETO, Otávio. (1994). Formação de gabinetes presidenciais no Brasil: coalizão versus cooperação. Nova Economia. Belo Horizonte, Departamento de Ciências Econômicas da Universidade Federal de Minas Gerais (UFMG), v. 4, $n^{\circ} 1$, p. 9-34, novembro.

ASHER, Herbert B. (1988). Presidential Elections and American Politics: voters, candidates and campaigns since 1952. 4th ed. Chicago: The Dorsey Press.

BALBACHEVSKY, Elisabeth. (1992). Identidade partidária e instituições políticas no Brasil. Lua Nova. São Paulo, Centro de Estudos de Cultura Contemporânea (Cedec), nº 26, p. 133-165.

BALBACHEVSKY, Elisabeth \& HOLZHACKER, Denilde O. (2004). Identidade, oposição e pragmatismo: o conteúdo estratégico da decisão eleitoral em 13 anos de eleições. Opinião Pública. Campinas, Centro de Estudos de Opinião Pública da Universidade Estadual de Campinas (Unicamp), v. 10, n. 2, p. 221-241.

BARTOLINI, Stefano. (2002). Electoral and party competition: analytical dimensions and empirical problems. In: GUNTHER, Richard, MONTERO, Ramón \& LINZ, Juan J. Political Parties: old concepts and new challenges. Oxford: Oxford University Press, p. 84-110. 
BARTOLINI, Stefano \& MAIR, PETER. (1990). Identity, Competition, and Electoral Availability: the stabilization of European electorates. Cambridge: Cambridge University Press.

BENNEY, Mark, GRAY, A. P. \& PEAR, R. H. (1956). How People Vote: a study of electoral behavior. New York/London: Humanities Press/Routledge \& Kegan Paul.

BERELSON, Bernard R., LAZARSFELD Paul F. \& MCPHEE, William N. (1954). Voting: a study of opinion formation in a presidential campaign. Chicago: The University of Chicago Press.

BOHN, Simone R. (2004). Evangélicos no Brasil: perfil socioeconômico, afinidades ideológicas e determinantes do comportamento eleitoral. Opinião Pública. Campinas, Centro de Estudos de Opinião Pública da Universidade Estadual de Campinas (Unicamp), v. 10, n. 2, p. 221-241.

BORBA, Juilian. (2005). Cultura política, ideologia e comportamento eleitoral: alguns apontamentos teóricos sobre o caso brasileiro. Opinião Pública. Campinas, Centro de Estudos de Opinião Pública da Universidade Estadual de Campinas (Unicamp), v. XI, nº 1, p. 147-168, março.

BORGES, Tiago Daher Padovezi. (2004). Os diferentes significados da categoria esquerda e direita. Mimeo. 25p.

BRAGA, Maria do Socorro S. (2006). O processo partidário-eleitoral brasileiro: padrões de competição política (1982-2002). São Paulo: Associação Editorial Humanitas/Fundação de Amparo à Pesquisa do Estado de São Paulo (Fapesp).

BRAGA, Maria do Socorro S. \& ROMA, Celso. (2002). Sistema partidário, eleições e a questão federativa no Brasil (1886-2000). In: SANTOS, André Marenco dos \& PINTO, Célia Regina Jardim. Partidos no Cone Sul: novos ângulos de pesquisa. Rio de Janeiro: Fundação Konrad Adenauer, p. 47-81.

BUTLER, David \& STOKES, Donald. (1969). Political Change in Britain: forces shaping electoral choices. New York: St. Martin's Press. 
CAMARGO, Orson. (2005). As bases ideológicas do voto na eleição presidencial de 2002 no Brasil. Monografia (Graduação) - Escola de Sociologia e Política de São Paulo.

CAMPBELL, Angus, CONVERSE, Philip E., MILLER, Warren E. \& STOKES, Donald E. (1960). The American Voter. Chicago: The University of Chicago Press.

CARMINES, Edward G. \& GOPOIAN, J. D. (1981). Issue coalitions, issueless campaigns: the paradox of rationality in American presidential elections. The Journal of Politics. Nashville, Department of Political Science, Vanderbilt University, v. 43, n. 4, p. 1170-1189, November.

CARREIRÃO, Yan de Souza. (2002). A decisão do voto nas eleições presidenciais brasileiras. Florianópolis; Rio de Janeiro: Ed. da UFSC; FGV Editora.

CARREIRÃO, Yan de Souza \& BARBETTA, Pedro Alberto. (2004). A eleição presidencial de 2002: a decisão do voto na região da grande São Paulo. Revista Brasileira de Ciências Sociais. São Paulo, Associação Nacional de Pós-Graduação e Pesquisa em Ciências Sociais (Anpocs), v. 19, nº 56, p. 7593, outubro.

CARREIRÃO, Yan de Souza \& KINZO, Maria D'Alva G. (2004). Partidos políticos, preferência partidária e decisão eleitoral no Brasil (1989/2002). Dados Revista de Ciências Sociais. Rio de Janeiro, Instituto Universitário de Pesquisas do Rio de Janeiro (luperj), v. 47, nº 1, p. 131-167.

CASTRO, Mônica M. M. de. (1994). Determinantes do comportamento eleitoral - a centralidade da sofisticação política. Tese (Doutorado) Instituto Universitário de Pesquisas do Rio de Janeiro (Iuperj)/Universidade Cândido Mendes (Ucam).

CATT, Helena. (1996). Voting Behaviour: a radical critique. London: Leicester University Press.

CAVALCANTI, Themistocles \& DUBNIC, Reisky, coords. (1964). Comportamento eleitoral no Brasil. Rio de Janeiro: Fundação Getúlio Vargas. 
CONCEIÇÃO, Samuel Barrichello. (2000). Gerações e ruptura institucional: influências no comportamento eleitoral no Brasil. Dissertação (Mestrado) Departamento de Ciência Política da Faculdade de Filosofia, Ciências e Letras da Universidade de São Paulo (USP).

CONVERSE, Philip. (1964). The nature of belief systems in mass publics. In: APTER, D., org. Ideology and Discontent. Nova York: The Free Press.

CRITTENDEN, John A. (1982). Parties and Elections in the United States. Englewood Cliffs: Prentice-Hall.

DALTON, Russell J. (1984). Cognitive mobilization and partisan dealignment in advanced industrial democracies. Journal of Politics. Nashville, Vanderbilt University, n.46, p. 264-284.

DALTON, Russell J. \& KLINGEMANN, Hans-Dieter. (2007). The Oxford Handbook of Political Behavior. Oxford: Oxford University Press.

DALTON, Russell J. \& WATTENBERG, Martin P. (1993). The not so simple act of voting. In: FINIFTER, Ada W., ed. Political Science: the state of the discipline II. Washington (DC): American Political Science Association (Apsa).

DALTON, Russell J. \& WATTENBERG, Martin P. (eds.) (2000). Parties without Partisans: political change in advanced industrial democracies. Oxford: Oxford University Press.

DALTON, Russell J., MCALLISTER, Ian \& WATTENBERG, Martin P. (2003). Democracia e Identificação partidária nas sociedades industriais avançadas. Análise Social. Lisboa, Instituto de Ciências Sociais da Universidade de Lisboa, v. XXXVIII, p. 295-320.

DIAMOND, Larry \& GUNTHER, Richard. (2001). Political Parties and Democracy. Baltimore: The Johns Hopkins University Press.

DOWNS, Anthony. (1999). Uma teoria econômica da democracia. São Paulo: Edusp.

DUVERGER, Maurice. Os partidos politicos. Rio de Janeiro/Brasília: Zahar/Ed. Da Universidade de Brasília. 
EVANS, Geoffrey \& NORRIS, Pipa, ed. (1999). Critical Elections: British parties and voters in long-term perspective. London: Sage.

FERNANDES, Hilton C. (2005). Voto e Gênero: o comportamento eleitoral feminino na sucessão presidencial de 2002. Dissertação (Mestrado) Departamento de Ciência Política da Universidade de São Paulo.

FERREIRA, Oliveiros S. (1960). Comportamento eleitoral em São Paulo. Revista Brasileira de Estudos Políticos. Belo Horizonte, Faculdade de Direito da Universidade Federal de Minas Gerais, nº 8, p. 162-228. (1964). Crise de poder do "Sistema" a as eleições paulistas de 1962. Revista Brasileira de Estudos Políticos. Belo Horizonte, Faculdade de Direito da Universidade Federal de Minas Gerais, n¹6, p. 179-226.

FIGUEIREDO, Argelina \& LIMONGI, Fernando. (1999). Executivo e Legislativo na nova ordem constitucional. Rio de Janeiro: FGV.

FIGUEIREDO, Argelina et al. (2002). Partidos e distribuição espacial dos votos na cidade de São Paulo (1994-2000). Novos Estudos Cebrap. São Paulo, Centro Brasileiro de Análise e Planejamento (Cebrap), nº 64, p. 153-176.

FIGUEIREDO, Marcus. (1991). A decisão do voto: democracia e racionalidade. São Paulo: Sumaré.

FIORINA, Morris. (1981). Retrospective Voting in American National Elections. New Haven: Yale University Press.

FLANIGAN, William H. \& ZINGALE, Nancy H. (1987). Political Behavior of the American Electorate. 6th ed. Boston: Allyn and Bacon.

GUNTHER, Richard, MONTERO, Ramón \& LINZ, Juan J. (2002). Political Parties: old concepts and new challenges. Oxford: Oxford University Press.

HOSMER, David W. \& LEMESHOW, Stanley. (1989). Applied Logistic Regression. Hoboken: J. Wiley \& Sons.

HOWELL, Susan E. (1981). Short term forces and changing partisanship. Political Behavior. Norwell, Kluwer Academic Publishers, v. 3, n. 2, p. 163180, June. 
INGLEHART, R. (1990). Cultural Shift in Advanced Industrial Society. Princeton: Princeton University Press.

JOHNSON-CARTEE, Karen S. \& COPELAND, Gary A. (1997). Manipulation of the American voter. Westport: Praeger.

KATZ, Richard \& MAIR, Peter. (1994). How Parties Organize: change and adaptation in party organization in Western democracies. London: Sage.

KEY, V. O. (1966). The Responsible Electorate: rationality in presidential voting (1936-1966). Cambridge: Belknap Press.

KINZO, Maria D`Alva Gil. (1992). A eleição presidencial de 1989: o comportamento eleitoral em uma cidade brasileira. Dados Revista de Ciências Sociais. Rio de Janeiro, Instituto Universitário de Pesquisas do Rio de Janeiro (luperj), v. 35, n 1, p. 49-66.

. (1993). Radiografia do quadro partidário brasileiro. São Paulo: Fundação Konrad Adenauer Stiftung.

. (1996a). A eleição presidencial de 1994 no Brasil: Fernando Henrique Cardoso e o Plano Real. In: PINTO, Célia Regina \& GUERRERO, Hugo, orgs. América Latina: o desafio da democracia nos anos 90. Porto Alegre/Montevidéu: Ed. da UFRGS/Associação de Universidades, p. 97-112.

(1996b). Democracia, comportamento eleitoral e representação política na América Latina. In: PINTO, Célia Regina \& GUERRERO, Hugo, orgs. América Latina: o desafio da democracia nos anos 90. Porto Alegre/Montevidéu: Ed. da UFRGS/Associação de Universidades, p. 149-153. . (2004). Partidos, eleições e democracia no Brasil pós-1985. Revista Brasileira de Ciências Sociais. São Paulo, Associação Nacional de PósGraduação e Pesquisa em Ciências Sociais (Anpocs), v. 19, nº 54, p. 23-40.

- (2005). Os partidos no eleitorado: percepções públicas e laços partidários no Brasil. Revista Brasileira de Ciências Sociais. São Paulo, Associação Nacional de Pós-Graduação e Pesquisa em Ciências Sociais (Anpocs), v. $20, n^{\circ} 57$, p. $65-81$.

KINZO, Maria D`Alva Gil, MARTINS JR., José Paulo \& BORIN, Ivan. (2003). Padrões de competição eleitoral na disputa para a Câmara paulistana (1992- 
2000). Novos Estudos Cebrap. São Paulo, Centro Brasileiro de Análise e Planejamento (Cebrap), no 65, p. 45-56.

KINZO, Maria D`Alva Gil, MARTINS JR., José Paulo \& BORIN, Ivan. (2004). Patrones de competencia electoral en la disputa por la cámara de diputados en Brasil (1994-2002). América Latina Hoy. Salamanca, Instituto Interuniversitario de Iberoamérica, v. 38, p. 143-162.

KNUTSEN, O. (2006). Class voting in Western Europe: a comparative longitudinal study. Lanham, Md.: Lexington.

LAAKSO, M. \& TAAGEPERA, R. (1979). The "effective" number of political parties: a measure with application to West Europe. Comparative Political Studies. London, Sage, v. 12, n. 1, p. 3-27.

LAMOUNIER, Bolívar. (1978). Comportamento eleitoral em São Paulo: passado e presente. In: LAMOUNIER, Bolívar \& CARDOSO, Fernando Henrique, coords. (1978). Os partidos e as eleições no Brasil. Rio de Janeiro/São Paulo: Paz e Terra/ Centro Brasileiro de Análise e Planejamento (Cebrap).

- (1978). Presidente Prudente: o crescimento do MDB num reduto arenista. In: REIS, Fábio Wanderley, org. Os partidos e o regime: a lógica do processo eleitoral brasileiro. São Paulo: Símbolo.

. (1983). São Paulo: a geografia do voto. Folhetim, suplemento da Folha de São Paulo, n. ${ }^{\circ} 315$.

. (1989). Partidos e utopias: o Brasil no limiar dos anos 90. São Paulo: Loyola.

. (1990). Eleições e democracia no Brasil: Discurso, teoria e história. Mimeo.

. (1991). Depois da transição: democracia e eleições no governo Collor. São Paulo: Loyola.

. (1994). A democracia brasileira de 1985 à década de 90: a síndrome da paralisia hiperativa. In: VELLOSO, João Paulo dos Reis, org. Governabilidade, sistema político e violência urbana. São Paulo: José Olympio, p. 25-63. 
LAMOUNIER, Bolívar, org. (1980). Voto de desconfiança: eleições e mudança política no Brasil, 1970-1979. Petrópolis/São Paulo: Vozes/Centro Brasileiro de Análise e Planejamento (Cebrap).

. (1990). De Geisel a Collor: o balanço da transição. São Paulo: Sumaré/Instituto de Estudos Econômicos, Sociais e Políticos de São Paulo (Idesp).

LAMOUNIER, Bolívar \& CARDOSO, Fernando Henrique, coords. (1978). Os partidos e as eleições no Brasil. Rio de Janeiro/São Paulo: Paz e Terra/ Centro Brasileiro de Análise e Planejamento (Cebrap).

LAMOUNIER, Bolívar \& KINZO, Maria D`Alva Gil. (1978). Partidos políticos, representação e processo eleitoral no Brasil: 1945-1978. BIB Revista Brasileira de Informação Bibliográfica em Ciências Sociais. São Paulo, Associação Nacional de Pós-Graduação e Pesquisa em Ciências Sociais (Anpocs), no 5, p. 11-32.

LAMOUNIER, Bolívar \& MENEGHELO, Raquel. (1986). Partidos políticos e consolidação democrática: o caso brasileiro. São Paulo: Brasiliense.

LAMOUNIER, Bolívar et al. (1990). Cem anos de eleições presidenciais. São Paulo: Instituto de Estudos Econômicos, Sociais e Políticos de São Paulo (Idesp).

LAVAREDA, Antônio. (1991). A democracia nas urnas: o processo partidário eleitoral brasileiro. Rio de Janeiro: Rio Fundo Editora.

LAZARSFELD, Paul F., BERELSON, Bernard \& GAUDET, Hazel. (1948). The People's Choice: how voter makes up his mind in a presidential campaign. 2nd ed. New York: Columbia University Press.

LEDUC, Lawrence et al. (1980). Partisanship, voting behavior, and elections outcomes in Canada. Comparative Politics. New York, City University of New York, v. 12, n. 4, p. 401-417.

LIMA JR., Olavo Brasil de, SCHMITT, Rogério \& NICOLAU, Jairo. (1992). A produção recente sobre partidos, eleições e comportamento político: um balanço bibliográfico. BIB Revista Brasileira de Informação Bibliográfica 
em Ciências Sociais. São Paulo, Associação Nacional de Pós-Graduação e Pesquisa em Ciências Sociais (Anpocs), n³ 34, p. 3-66.

LIMA JR., Olavo Brasil de. (1983). Os partidos políticos brasileiros: a experiência federal e regional - 1945/1964. Rio de Janeiro: Graal.

. (1993). Democracia e instituições políticas no Brasil dos anos 80.

São Paulo: Loyola.

. (1999a). Eleições presidenciais: mudanças, contexto e implicações.

Revista Brasileira de Ciências Sociais. São Paulo, Associação Nacional de Pós-Graduação e Pesquisa em Ciências Sociais (Anpocs), v. 14, n 40, p. 11 30.

. (1999b). Partidos, eleições e Poder Legislativo. In: MICELI, Sergio, org. O que ler na ciência social brasileira (1970-1995). Volume III. Ciência Política. São Paulo: Associação Nacional de Pós-Graduação e Pesquisa em Ciências Sociais (Anpocs), p. 13-57.

LIMA JR., Olavo Brasil de, org. (1997). O sistema partidário brasileiro: diversidades e tendências - 1982-1994. Rio de Janeiro: FGV.

LIPSET, S. M. (1981). Political Man: the social bases of politics. Baltimore: The Johns Hopkins University Press.

LIPSET, S. M. \& ROKKAN, S. (1967). Cleavage structure, party systems, and voter alignments: an introduction. In LIPSET, S. M. \& ROKKAN, S. (ed.). Party Systems and Voter Alignments. New York: The Free Press.

MACKUEN, Michael B. \& RABINOVITZ, George, eds. (2003). Electoral Democracy. Ann Arbor: The University of Michigan Press.

MAINWARING, Scott. (1992). Brazilian party underdevelopment in comparative perspective. Political Science Quaterly. New York, The Academy of Political Science, v. 107, n. 4, p. 677-707.

. (1997). Multipartism, robust federalism and presidentialism. In: MAINWARING, S. \& SHUGART, M. Presidentialism and Democracy in Latin America: party systems in Latin America. Cambridge: Cambridge University Press, p. 55-109. 
MAINWARING, S. \& SCULLY, T. R. (1995). Building democratic institutions: party systems in Latin America. Stanford: Stanford University Press.

MARGOLIS, Michael. (1977). From confusion to confusion: issues and the American voter (1956-1972). The American Political Science Review. Washington (DC), American Political Science Association, v. 71, n. 1, p. 31-43. MARTIN, John B. (1874). Elections of 1868 and 1874. Journal of the Statistical Society of London. London, Royal Statistical Society, v. 37 n. 2, p. $193-230$.

MARTINS JR., José Paulo \& DANTAS, Humberto. (2004). O índice de participação e a importância da educação. Opinião Pública. Campinas, Centro de Estudos de Opinião Pública da Universidade Estadual de Campinas (Unicamp), v. 10, n. 2, p. 268-287.

MENEGHELO, Raquel. (1994). Partidos e tendências de comportamento: o cenário em 1994. In: DAGNINO, Evelina (org.). Anos 90, política e sociedade no Brasil. São Paulo: Brasiliense.

. (1995). Electoral Behavior in Brazil: the 1994 presidential elections.

International Social Science Journal. Oxford/Cambridge: Blackwell Publishers, n.146.

. (1998). Partidos e governo no Brasil contemporâneo (1985-1997). São Paulo: Paz e Terra.

MICELI, Sergio, org. (1999). O que ler na ciência social brasileira (19701995). Volume III. Ciência Política. São Paulo: Associação Nacional de PósGraduação e Pesquisa em Ciências Sociais (Anpocs).

MILLER, A. H., WATTENBERG, M. \& MALANCHUK, O. (1986). Schematic assessments of presidential candidates. The American Political Science Review. Washington (DC), American Political Science Association, v. 80, n. 2, p. 521-540.

MILLER, Warren \& SHANKS, J. Merrill. (1996). The New American Voter. Cambridge: Harvard University Press. 
MILNE, R. S. \& MACKENZIE, H. C. (1958). Marginal Seat. London: Hansard Society.

MOISÉS, José Álvaro. (1993). Elections, political parties and political culture in Brazil: changes and continuities. Journal of Latin American Studies. New York, Cambridge University Press, v. 25, n. 3, p. 575-611.

MOYA, Maurício A. (2005). Executivo versus Legislativo: os vetos presidenciais no Brasil (1988-2000). Tese (Doutorado) - Departamento de Ciência Política da Universidade de São Paulo.

NEWMARCH, Willian. (1857). On the electoral statistics of the countries and boroughs in England and Wales during the twenty-five years from the Reform Act of 1832 to the present time. Journal of the Statistical Society of London. London, Royal Statistical Society, v. 20, n. 2, p. 169-234.

NICOLAU, Jairo Marconi. (1998). A volatilidade eleitoral nas eleições para a Câmara dos Deputados brasileira (1982-1994). In: XXII Encontro Anual da Associação Nacional de Pós-Graduação e Pesquisa em Ciências Sociais (ANPOCS), 27-31 de outubro de 1998, Caxambu. mimeo.

NICOLAU, Jairo Marconi, org. (1998). Dados eleitorais do Brasil (19821996). Rio de Janeiro: Reven/Instituto Universitário de Pesquisas do Rio de Janeiro (luperj)/Universidade Cândido Mendes (Ucam).

NIE, N. et al. (1981). The Changing American Voter. Cambridge: Harvard University Press.

NOVAES, Carlos A. M. (1996a). A geografia do voto em São Paulo. Novos Estudos Cebrap. São Paulo, Centro Brasileiro de Análise e Planejamento (Cebrap), n. 45.

. (1996b). O primeiro turno da eleição para prefeito em São Paulo.

Novos Estudos Cebrap. São Paulo, Centro Brasileiro de Análise e Planejamento (Cebrap), n. 46.

PEDERSEN, Mogens. (1980). On measuring party system change: a methodological critique and a suggestion. Comparative Political Studies. London, Sage, v. 4, n. 12, p. 387-403. 
PEDERSEN, Mogens. (1990). Electoral volatility in Western Europe: 19481977. In MAIR, Peter, ed. The West European Party System. Oxford: Oxford University Press, p. 195-207.

. (1991). A direita que flutua: o voto conservador na cidade de São Paulo. Novos Estudos Cebrap. São Paulo, Centro Brasileiro de Análise e Planejamento (Cebrap), n. ${ }^{\circ}$ 29, mar/1991.

. (1993). São Paulo 92, a vitória da direita. Novos Estudos Cebrap. São Paulo, Centro Brasileiro de Análise e Planejamento (Cebrap), n. ${ }^{0} 35$.

PEREIRA, Carlos \& MUELLER, Bernardo. (2003). Partidos fracos na arena eleitoral e partidos fortes na arena legislativa: a conexão eleitoral no Brasil. Dados Revista de Ciências Sociais. Rio de Janeiro, Instituto Universitário de Pesquisas do Rio de Janeiro (luperj), v. 46, nº 4, p. 735-771.

PERES, Paulo Sérgio. (2000). O espectro da instabilidade: sistema partidário e volatilidade eleitoral no Brasil democrático. Dissertação (Mestrado) Departamento de Ciência Política da Universidade de São Paulo.

. (2002). Sistema partidário e instabilidade eleitoral no Brasil. In: SANTOS, André Marenco dos \& PINTO, Célia Regina Jardim, orgs. Partidos no Cone Sul: novos ângulos de pesquisa. Rio de Janeiro: Fundação Konrad Adenauer, p. 13-46.

PEREZ-LINAN, Anibal. (2002). Television news and political partisanship. Political Research Quarterly. New York, The Academy of Political Science, v. 55, n. 3 , p. 571-588.

PETROCIK, John R. \& DESPOSATO, Scott W. (2004). Incumbency and short-term influences on voters. Political Research Quarterly. New York, The Academy of Political Science, v. 57, n. 3, p. 363-373.

PIERUCCI, Antonio. F. (1989). A direita mora do outro lado da cidade. Revista Brasileira de Ciências Sociais. São Paulo, Associação Nacional de Pós-Graduação e Pesquisa em Ciências Sociais (Anpocs), n.o 10, V. 4.

- (1987). As bases da nova direita. Novos Estudos Cebrap. São Paulo, Centro Brasileiro de Análise e Planejamento (Cebrap), n. ${ }^{\circ} 19$. 
PIERUCCI, Antonio. F. (1986). Um toque de classe média baixa. Novos Estudos Cebrap. São Paulo, Centro Brasileiro de Análise e Planejamento (Cebrap), n. ${ }^{\circ} 14$.

PIMENTEL JR., Jairo Tadeu Pires. (2004). Eleitores, partidos e conhecimento político. 49 p. Mimeo.

. (2007). Razão e emoção no voto: o caso da eleição presidencial de 2006. Dissertação (Mestrado) - Departamento de Ciência Política da Universidade de São Paulo.

PINTO, Célia Regina \& GUERRERO, Hugo. orgs.. (1996). América Latina: o desafio da democracia nos anos 90. Porto Alegre/Montevidéu: Ed. da UFRGS/Associação de Universidades.

PIVEN, Frances Fox, ed. (1992). Labor Parties in Postindustrial Societies. New York: Oxford.

PIZZORNO, Alessandro. (1970). An introduction to the theory of political participation. Social Science Information. London, Sage, v. 9, n. 5.

POMPER, Gerald M. (1988). Voters, Elections and Parties: the practice of democratic theory. New Brunswick: Transaction Publishers.

POPKIN, Samuel. (1994). Reasoning voter: communication and persuasion in presidential campaigns. Chicago: The University of Chicago Press.

POPKIN, S. et al. Comment: what have you done for me lately? Toward an investment theory of voting. The American Political Science Review. Washington (DC), American Political Science Association, v. 70, n. 3, p. 779-805. POWERS, Daniel A. \& XIE, Yu. (2000). Statistical Methods for Categorical Data Analysis. San Diego: Academic Press.

REIS, Fábio Wanderley. (1978a). As eleições em Minas Gerais. In: LAMOUNIER, Bolívar \& CARDOSO, Fernando Henrique, coords. Os partidos e as eleições no Brasil. Rio de Janeiro/São Paulo: Paz e Terra/ Centro Brasileiro de Análise e Planejamento (Cebrap). 
REIS, Fábio Wanderley. (1978b). Classe Social e opção operária. In: REIS, Fábio Wanderley, org. Os partidos e o regime: a lógica do processo eleitoral brasileiro. São Paulo: Símbolo.

. (1978c). Conclusão: em busca da lógica do processo eleitoral brasileiro. In: REIS, Fábio Wanderley, org. Os partidos e o regime: a lógica do processo eleitoral brasileiro. São Paulo: Símbolo.

- (1988). Identidade, política e teoria da escolha racional. Revista Brasileira de Ciências Sociais. São Paulo, Associação Nacional de PósGraduação e Pesquisa em Ciências Sociais (Anpocs), v. 3, nº 6, p. 26-38.

REIS, Fábio Wanderley, org. (1978). Os partidos e o regime: a lógica do processo eleitoral brasileiro. São Paulo: Símbolo.

REIS, Fábio Wanderley \& CASTRO, Mônica M. M. de. (1992). Regiões, classe e ideologia no processo eleitoral brasileiro. Lua Nova. São Paulo, Centro de Estudos de Cultura Contemporânea (Cedec), n. 26, p. 81-131.

- (2001). Democracia, civismo e cinismo: um estudo empírico sobre normas e racionalidade. Revista Brasileira de Ciências Sociais. São Paulo, Associação Nacional de Pós-Graduação e Pesquisa em Ciências Sociais (Anpocs), v.16, no 45, p. 25-46.

REPASS, David E. (1971). Issue salience and party choice. The American Political Science Review. Washington (DC), American Political Science Association, v. 65, n. 2, p. 389-400.

RODRIGUES, Leôncio Martins. (1995a). As eleições de 1994: uma apreciação geral. Dados Revista de Ciências Sociais. Rio de Janeiro, Instituto Universitário de Pesquisas do Rio de Janeiro (luperj), v. 38, no 1, p. 71-92.

. (1995b). Eleições, fragmentação partidária e governabilidade. Novos Estudos Cebrap. São Paulo, Centro Brasileiro de Análise e Planejamento (Cebrap), no 41, p. 78-90.

. (2002). Ideologia e composição social. São Paulo: Edusp.

ROSE, Richard \& URWIN, Derek. (1969). Social cohesion, political parties and strains in regimes. Comparative Political Studies. London, Sage, n. 2. 
ROSSO, Jorge Aurélio. (2004). O peso do voto retrospectivo na disputa eleitoral de São Paulo em 1996. Dissertação (Mestrado) - Departamento de Ciência Política da Universidade de São Paulo.

SADEK, Maria Tereza, org. (1989). Eleições/1986. São Paulo: Vértice/ Instituto de Estudos Econômicos, Sociais e Políticos de São Paulo (Idesp).

SAMUELS, David. (1997). Determinantes do voto partidário em sistemas eleitorais centrados no candidato: evidências sobre o Brasil. Dados Revista de Ciências Sociais. Rio de Janeiro, Instituto Universitário de Pesquisas do Rio de Janeiro (luperj), v. 40, nº 3, p. 493-535.

. (2004). As bases do petismo. Opinião Pública. Campinas, Centro de

Estudos de Opinião Pública da Universidade Estadual de Campinas (Unicamp), v. 10, n. 2, p. 221-241.

SANTOS, André Marenco dos \& PINTO, Célia Regina Jardim. (2002). Partidos no Cone Sul: novos ângulos de pesquisa. Rio de Janeiro: Fundação Konrad Adenauer.

SANTOS, Fabiano. (1999). Instituições eleitorais e desempenho do presidencialismo no Brasil. Dados Revista de Ciências Sociais. Rio de Janeiro, Instituto Universitário de Pesquisas do Rio de Janeiro (Iuperj), v. 42, $\mathrm{n}^{\mathrm{0}} 1$, p. 111-138.

SANTOS, Wanderley Guilherme dos. (1987). Crise e castigo: partidos e generais na política brasileira. Rio de Janeiro: Vértice.

. (1998). Décadas de espanto e uma apologia democrática. Rio de Janeiro: Rocco.

SARLVIK, Bo \& CREWE, Ivor. (1983). Decade of Dealignment: the conservative victory of 1979 and electoral trends in the 1970's. New York: Cambridge University Press.

SCHMITT, Rogério. (1999). Coligações eleitorais e sistema partidário no Brasil. Tese (Doutorado) — Instituto Universitário de Pesquisas do Rio de Janeiro (luperj)/Universidade Cândido Mendes (Ucam), Rio de Janeiro.

SILBEY, Joel H. et al., (eds). (1978). The History of American Electoral Behavior. Princeton : Princeton University Press. 
SILVEIRA, Flávio E. (1996). O novo eleitor não-racional. 1996. Tese (Doutorado) - Departamento de Sociologia da Faculdade de Filosofia, Letras e Ciências Humanas da Universidade de São Paulo.

SIMÃO, Azis. (1956). O voto operário em São Paulo. Revista Brasileira de Estudos Políticos. Belo Horizonte, Faculdade de Direito da Universidade Federal de Minas Gerais, nº 1, p. 130-141.

SINGER, André. (1990). Collor na periferia: a volta por cima do populismo? In: LAMOUNIER, Bolivar, org. De Geisel a Collor: o balanço da transição. São Paulo: Sumaré/ Instituto de Estudos Econômicos, Sociais e Políticos de São Paulo (Idesp).

. (2000). Esquerda e direita no eleitorado brasileiro. São Paulo: Edusp.

SOARES, Gláucio Ary Dillon. (1961a). Classes sociais, strata sociais e as eleições presidenciais de 1960. Sociologia. v. XXIII, n. 3, p.217-238.

. (1961b). As bases ideológicas do lacerdismo. Revista Civilização Brasileira. Rio de Janeiro, Civilização Brasileiro, nº 4, p. 49-70.

(1973). Sociedade e política no Brasil. São Paulo: Difusão Européia do Livro.

STOKES, Donald. (1966). Spatial models of party competition. In: CAMPBELL, Angus et al. Elections and political order. New York: Wiley STROM, Kaare. (1990). A behavioral theory of competitive political parties. The American Journal of Political Science. Austin, University of Texas, Midwest Political Science Association, University of Texas Press, v. 34, n. 2, p. 565-598.

VON METTENHEIM, Kurt. (1995). The Brazilian voter: mass politics in democratic transition, 1974-1982. Pittsburgh: University of Pittsburgh Press.

WATTENBERG, Martin P. (1991). The Rise of Candidate-Centered Politics: presidential elections of the 1980's. Cambridge: Harvard University Press.

. (1998). The Decline of American Political Parties, 1952-1996.

Cambridge: Harvard University Press. 
WEBB, Paul, FARRELL, David M. \& HOLLIDAY, Ian, ed. (2002). Political

Parties in Advanced Industrial Democracies. Oxford: Oxford University Press. 